Maria Luísa Carvalho de Almeida Sampaio

\title{
A desordem das gerações e a recusa escolar: estudos de casos de adolescentes em psicopedagogia
}

Universidade de São Paulo

Faculdade de Educação

São Paulo - 2008 


\title{
Maria Luísa Carvalho de Almeida Sampaio
}

\section{A desordem das gerações e a recusa escolar: estudos de casos de adolescentes em psicopedagogia}

\begin{abstract}
Tese apresentada ao Programa de Pós-Graduação em Educação da Universidade de São Paulo, como requisito parcial à obtenção do título de Doutor em Educação, sob orientação da Profa. Dra. Maria Cecília Cortez Christiano de Souza
\end{abstract}

Universidade de São Paulo

Faculdade de Educação

São Paulo - 2008 
À memória de Benedito, meu pai. Sempre presente. 
Ao Beto,

Por seu olhar amoroso, que me faz atravessar fronteiras. 


\section{Agradecimentos}

À Profa. Dra. Maria Cecília Cortez Christiano de Souza, pela segunda vez minha orientadora, pela generosidade de sempre. Foi um enorme prazer partilhar, mais uma vez, de sua companhia, erudição e humanidade.

À Profa. Dra. Mônica do Amaral, por suas preciosas sugestões no exame de qualificação, que esboçaram um caminho possível e fecundo para esta pesquisa.

Ao Prof. Dr. Amaury de Moraes, pela abertura e interesse no exame de qualificação.

À minha mãe, Tél, e meus irmãos Carlota, Quico, Carmo, Bel e Vicente. Pelos laços que se estreitaram ainda mais neste último ano.

Às colegas e amigas que leram parte dessa pesquisa e contribuíram para seu enriquecimento: Patrícia Torralba Horta, Paula Nascimento da Silva e Stella Vendramini Reis.

À Gisela Tartuce e Sonia Parente, que acompanharam, de perto e de longe, essa caminhada.

Ao Ruy Proença, Marília Alves Brandileone, Denise Demange e Ângela Barbosa de Oliveira, pelas contribuições na finalização deste trabalho.

Às crianças e adolescentes do consultório, e, muito especialmente, ao Fábio e ao Otto, razão de ser desta pesquisa. 
A condição humana gera uma ordem do tempo, uma vez que a sucessão das idades, na vida de cada indivíduo, tem que se articular à cadeia das gerações, e respeitá-la para com ela se harmonizar, sob pena de retorno ao caos.

Jean-Pierre Vernant 
Resumo: Esta pesquisa qualitativa tem como base estudos de casos de adolescentes com dificuldades escolares, analisados dentro do contexto da psicopedagogia clínica. Trata-se de jovens de famílias de nível socioeconômico médio, freqüentadores de escolas particulares e que, apesar da formação familiar, apresentam dificuldades de aprendizagem. A princípio, a problemática dos adolescentes parece corresponder à falta de autonomia no processo de aprendizagem escolar. No entanto, um exame mais atento revela a ambivalência dos jovens em face da ordem escolar. O aprofundamento na dinâmica familiar desses jovens indica certa conivência dos pais diante dessa ambivalência. Portanto, são casos que remetem à complementaridade entre certas configurações familiares e os problemas na escolaridade dos adolescentes, em virtude do enfraquecimento das barreiras geracionais e normativas entre pais e filhos. Nesse sentido, o objetivo da pesquisa consiste em investigar a recusa escolar entre os adolescentes e verificar a influência da negação da diferença geracional dos adultos nessa problemática. Para tanto, analisam-se primeiramente, os pressupostos históricos e teóricos da psicopedagogia, e, mais detidamente, os da psicopedagogia clínica proposta por Sara Paín. Utilizando a metodologia de investigação científica dos estudos de casos, realiza-se uma descrição detalhada dos casos, explicitando suas variáveis. Os estudos de casos evidenciam um conflito subjacente: o anseio do jovem de conquistar a autonomia, em contraposição às tendências que mantêm as relações de dependência com os pais. Recorre-se à psicanálise para aprofundar certos aspectos desse conflito, com base no trabalho de Jeammet e Corcos. Segundo esses autores, a adolescência demandaria ao jovem a articulação entre o mundo interno e o mundo externo, isto é, um trabalho psíquico de consolidação das bases narcísicas e das relações objetais, no sentido de o sujeito concluir seu processo de identificação, para assim se dirigir ao mundo adulto. Esse trabalho se realizaria por meio da dependência (transitória) em relação aos pais. No caso dos jovens analisados, há uma reação negativa à dependência mediante a recusa de intercâmbio com os pais e com os objetos de interesses, dentre eles, a escola. Constata-se que nesses casos se apresentam situações que revelam uma pseudomutualidade nas relações entre pais e filhos e a decorrente fragilização de limites em benefício do aumento das exigências narcísicas. Procurando compreender esses casos dentro do contexto da denominada pós-modernidade e seus efeitos sobre as relações intergeracionais, investiga-se ainda o amplo processo de mudanças sociais da segunda metade do século XX, derivando no que Lipovestky chama de cultura narcísica. Dentre os elementos da cultura narcísica que afetam as relações intergeracionais, constam a idealização social da juventude, a erosão das identidades e a dissolução das normas educativas. Nas famílias estudadas, verificou-se ainda a atualização, em termos pós-modernos, de traços culturais atribuídos à família brasileira por pensadores como Sérgio Buarque de Holanda. O fenômeno da modernização reativa, da superposição de valores tradicionais e modernos levou, como se constata nesses estudos de casos, à diluição de diferenças de gerações. Nesse sentido, a recusa escolar dos jovens pode consistir em uma atuação da recusa do luto da juventude por parte dos pais.

\section{Palavras-chave:}

Adolescência, autonomia, dependência, recusa escolar, psicopedagogia. 
Abstract: This qualitative research is based on case studies about adolescents with academic difficulties, analyzed within the context of clinical educational psychology. Belonging to families in the middle social economic level, these youth attend private schools and show learning difficulties despite their family background. At first, this issue among adolescents seems to correspond to their lack of independence in school. However, a more careful examination reveals the youths' ambivalence in regard to the school structure. The in-depth study of these youths' family dynamics somehow indicates the parents' complicity with this ambivalence. Thus, they are cases that may be traced back to a link between certain familial configurations and low academic achievement. This complimentarity of social spheres is due to weakened generational and normative barriers between parents and children. In this sense, this study aims at investigating the adolescents' rejection of their own education and verifying the negation of the adults' generational difference as an influence in this problem. To that end, we begin by analyzing the historical and theoretical presuppositions of educational psychology, and more specifically, those of clinic educational psychology as proposed by Sara Paín. Using the methodology of scientific investigation for study cases, we carry out a detailed description of cases by making their variables explicit. The case studies demonstrate an underlying conflict: the youth's eagerness to attain independence in contrast with trends that suggest a lasting relationship of dependence on parents. We refer to psychoanalysis to deepen certain aspects of this conflict with the work of Jeammet and Corcos as our basis. According to these authors, adolescence is the stage in which the individual psychically consolidates the narcissistic bases and object relations, thus concluding his/her process of maturation as an adult - which would happen by means of the (transitory) dependence on the parents. In the analyzed cases, there is a negative reaction to dependence upon the denial of exchange with parents and objects of interest, one of which is school. It is evident that these cases point out situations of both pseudomutuality in relations between children and parents and the ensuing fragilization of the limits upon the increase of narcissistic demands. In an attempt to understand these cases within the so-called post-modern context and its effects on intergenerational relations, this study investigates the wide process of social changes that occurred in the second half of the twentieth century, locating what Lipovestky calls narcissist culture. Among the elements of narcissist culture affecting intergenerational relations, are the social idealization of youth, the erosion of identities and the dissolution of educational norms. The families focused on still reveal the predominance of the cultural traces attributed to the Brazilian family by thinkers such as Sergio Buarque de Holanda. As affirmed by these case studies, the phenomenon of a new modernity, along with the superposition of traditional and modern values, led to the dilution of generational differences. Thus, the adolescents' rejection of formal education may consist in the parents' own act of denying the mourning of their youth.

\section{Key words:}

Adolescence, autonomy, dependence, school denial 


\section{Sumário}

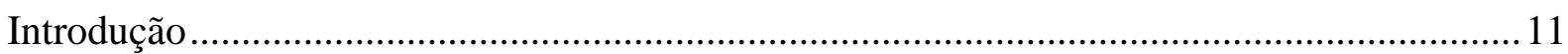

1 Evolução e fundamentos da psicopedagogia clínica ..............................................................19

1.1 Intervenções acerca do fracasso escolar - a reeducação psicopedagógica ......................22

1.2 Contribuições da psicanálise à psicopedagogia ..........................................................26

$1.3 \mathrm{O}$ fracasso escolar no Brasil - as vicissitudes do processo de democratização

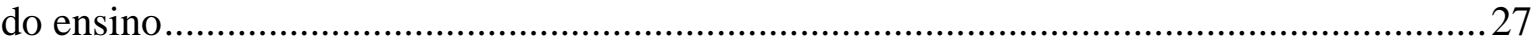

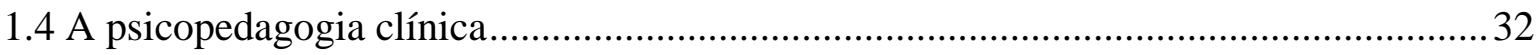

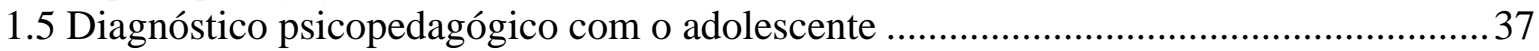

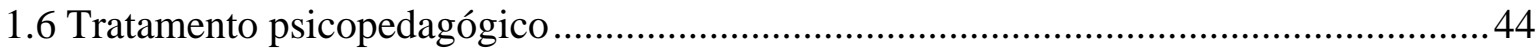

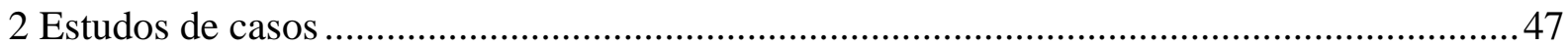

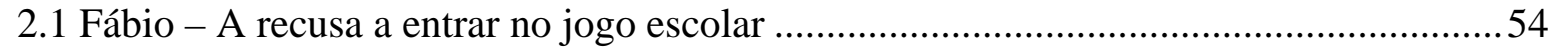

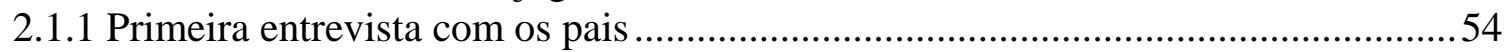

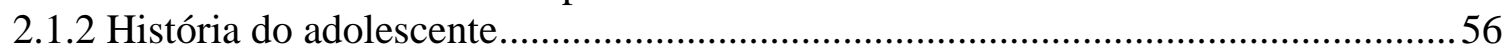

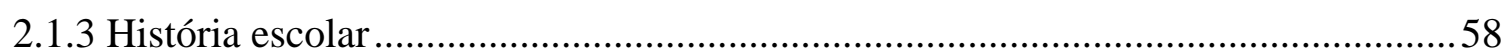

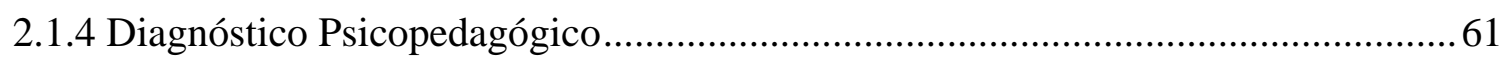

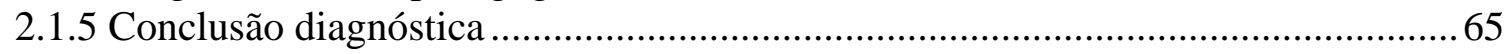

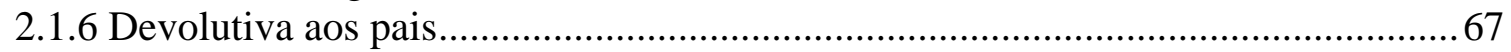

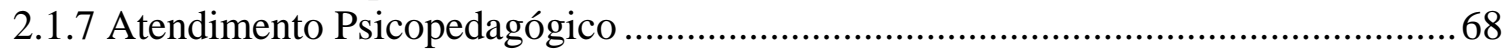

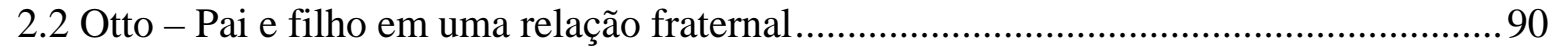

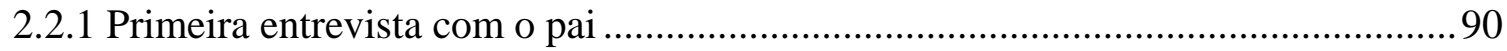

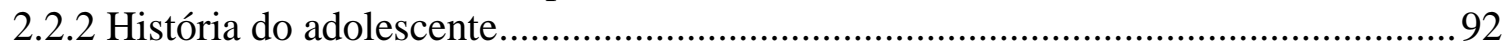

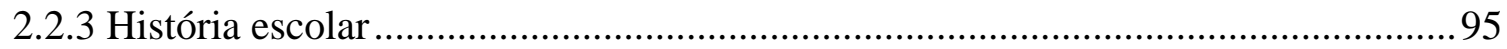

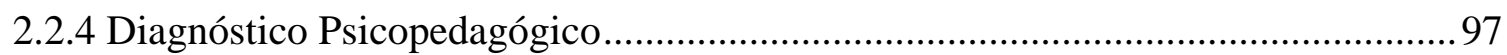

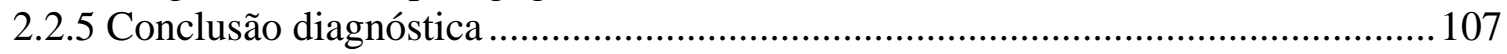

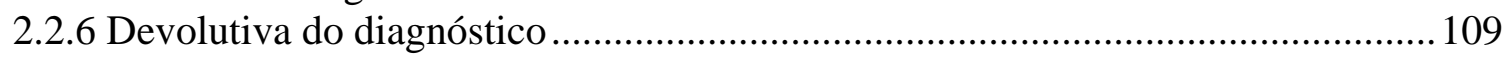

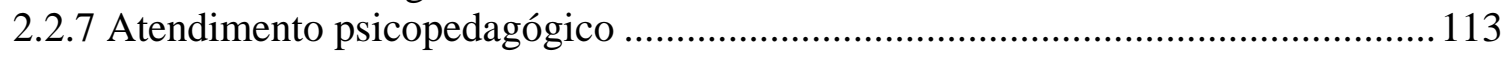

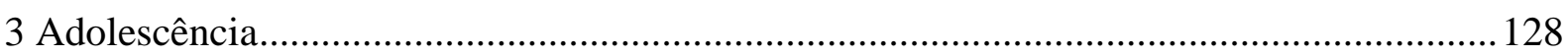

$3.1 \mathrm{O}$ trabalho subjetivo decorrente das transformações da adolescência..........................128

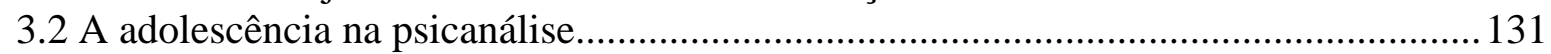

3.3 A passagem do corpo infantil para o corpo adulto e suas conseqüências .....................136

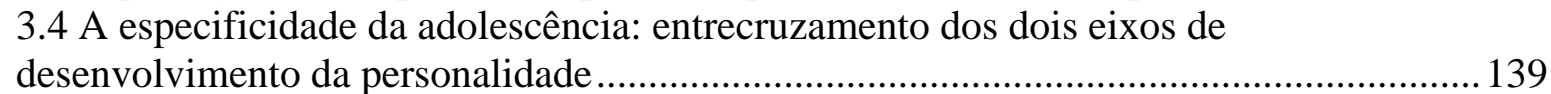

3.4.1 Eixo da constituição das bases narcísicas e das relações objetais ......................... 140

3.4.2 Eixo da dependência-autonomia........................................................................... 144

3.5 A adolescência e o risco do antagonismo dos eixos de desenvolvimento da

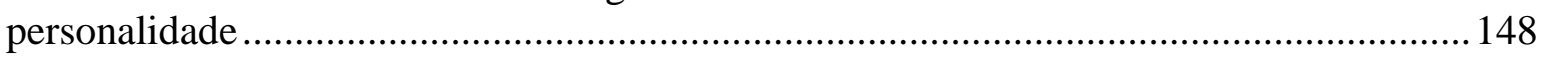

3.6 A problemática da dependência na adolescência ..................................................... 150

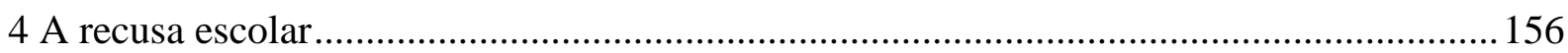

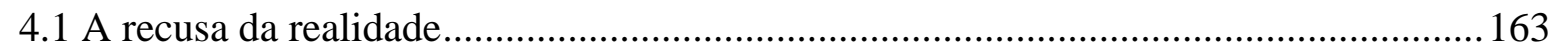

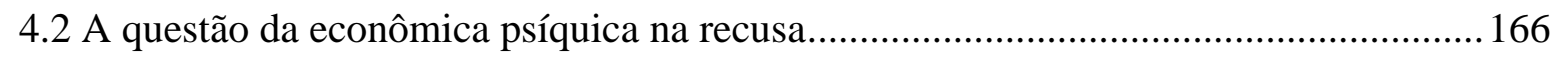

5 Narcisismo ou a condição subjetiva na contemporaneidade................................................178

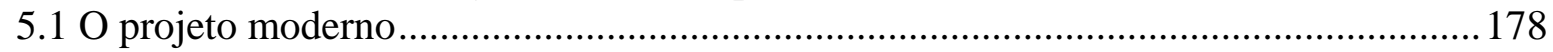


5.2 A modernidade em crise ........................................................................................ 180

$5.3 \mathrm{O}$ choque do novo - o movimento modernista …………..........................................182

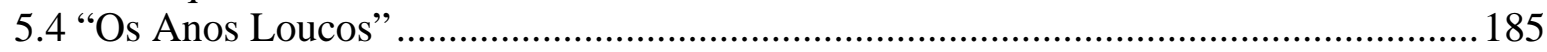

5.5 Disseminação do processo de personalização ............................................................... 187

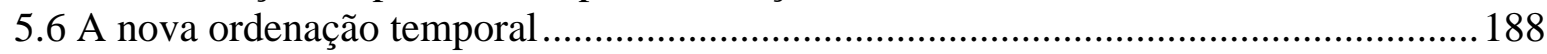

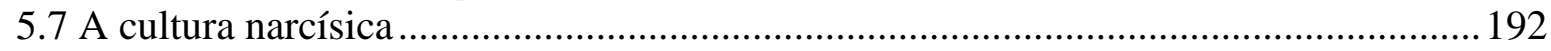

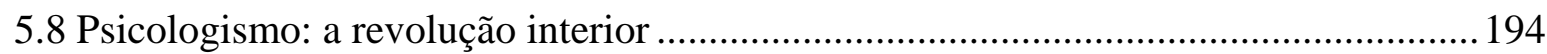

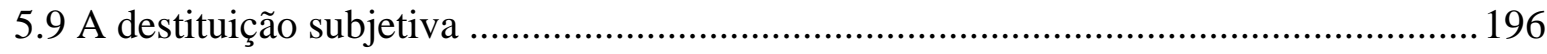

6 A família afetiva contemporânea....................................................................................... 200

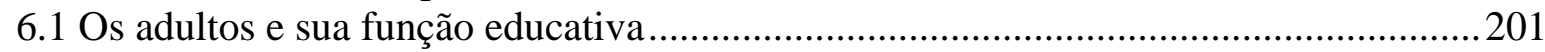

6.2 Do laço pessoal e familiar para o laço social …………………………………….........2203

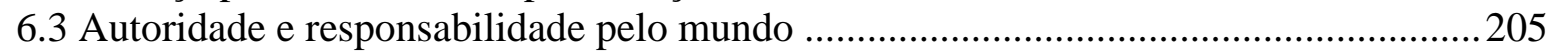

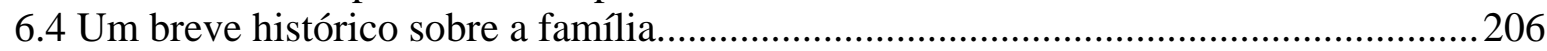

6.5 Um novo olhar para a autoridade parental................................................................. 208

6.6 A família afetiva contemporânea................................................................................2210

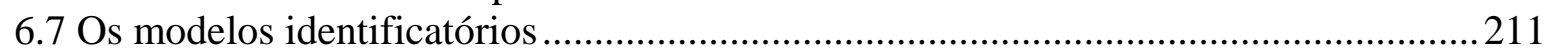

6.8 A família de classe média brasileira: o mergulho no novo...............................................2214

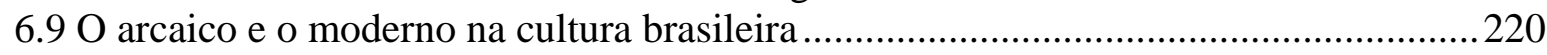

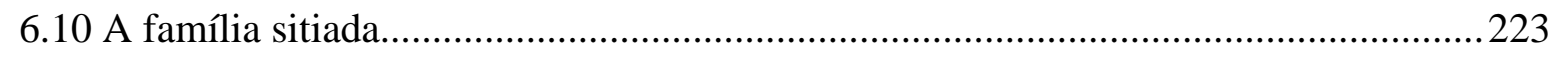

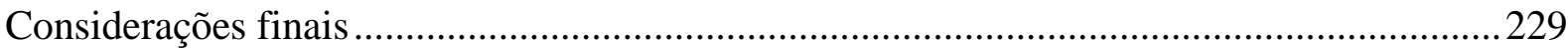

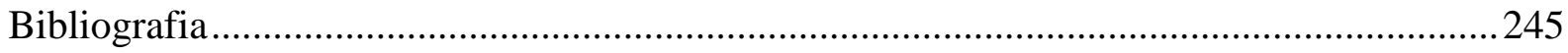




\section{Introdução}

Esta pesquisa se ancora em minha experiência, já longa, como psicopedagoga clínica, mais especificamente, no atendimento de adolescentes que apresentam problemas de aprendizagem escolar. Meu trabalho tem como referência a psicopedagogia de orientação psicanalítica, que considera os aspectos subjetivos no processo de aprendizagem e a participação do desejo do sujeito na construção (ou não) do conhecimento.

A clínica da psicopedagogia com adolescentes apresenta alguns desafios que me levaram a desenvolver essa pesquisa exploratória. $\mathrm{O}$ primeiro diz respeito à sua fundamentação teórica. A psicopedagogia dispõe de uma vasta bibliografia sobre o problema de aprendizagem na infância, mas, em relação aos adolescentes, não parece oferecer contribuições expressivas. Já a psicanálise apresenta uma literatura já extensa sobre a adolescência, no entanto pouca referência faz às dificuldades de aprendizagem na escola.

A universalização do acesso ao ensino fundamental coloca, a cada ano, adolescentes e jovens às portas do ensino médio, e a antiga idéia, cara às classes médias, de que os estabelecimentos particulares estariam infensos à crise da escola pública, acaba por cair por terra diante dos resultados das últimas avaliações. ${ }^{1}$ Diante desse fato, a escolaridade dos adolescentes tem sido motivo de preocupação de pais e de educadores. Isso se reflete na clínica de psicopedagogia, pois tem sido crescente o número de adolescentes com queixas escolares.

O segundo desafio diz respeito a alguns aspectos do contexto social contemporâneo que parecem favorecer a emergência dos problemas de aprendizagem escolar entre os jovens. Dentre eles, é possível destacar o enfraquecimento das barreiras geracionais e das proibições, a necessidade da satisfação imediata dos impulsos e o apelo da cultura juvenil, que parece ocupar grande parte da vida dos adolescentes. Esses aspectos parecem dificultar a entrada na lógica do trabalho escolar, necessária à sistematização do conhecimento escolar.

Outro aspecto relacionado às tendências sociais que também afeta a aprendizagem dos jovens é a necessidade premente de cada um garantir o seu espaço de individualidade e de

\footnotetext{
${ }^{1}$ As médias das notas do exame SAEB (Sistema de Avaliação da Educação Básica) de 2005 de alunos da $8^{\circ}$ série do Ensino Fundamental e do $3^{\circ}$ ano do Ensino Médio, se comparadas às de 1995, indicam uma queda significativa no desempenho dos alunos das escolas públicas e particulares. www.inep.gov.br/download/saeb/2005/SAEB1995_2005.pdf. Acesso em 19/03/08.
} 
autonomia. Quando se trata da educação de crianças e de adolescentes, algumas mediações sociais que antes pareciam ser evidentes, no sentido de conduzir os adolescentes ao mundo comum, na atualidade tomam uma conotação de opção ou gosto do adulto, e não mais de uma obrigação. Paradoxalmente, a autonomia, tão valorizada socialmente, parece estar mais na ordem do ideal para os jovens, do que uma real conquista.

O tema da autonomia constitui um dos eixos centrais na vida dos jovens. Sua conquista representa o passaporte para o mundo dos adultos, mas o que dificilmente se percebe é que a autonomia consiste num árduo processo, e, paradoxalmente, ele não é linear. É feito de idas e vindas, de acordo com as interações e ressonâncias entre o sujeito e os pais, ou, como dizem alguns psicanalistas: entre o mundo interno e o mundo externo.

O favorecimento da conquista da autonomia do sujeito na aprendizagem consiste num dos objetos de trabalho da psicopedagogia e, no caso dos adolescentes, a dificuldade na aquisição da mesma representa um elemento bastante significativo na problemática do sujeito.

Os estudos de casos que foram selecionados nesta pesquisa se situam no entrecruzamento da esfera do singular com a esfera do social. Eles trazem questões que dizem respeito à singularidade desses jovens, que parecem estar articuladas a certas tendências da totalidade social. Nesses casos, o sintoma apresentado pelos adolescentes, manifesto tanto pela falta de autonomia na aprendizagem, como pela recusa a integrar-se à ordem escolar, aparenta estar associado à configuração atual das relações intergeracionais.

O objetivo desta pesquisa consiste, então, em investigar certos problemas de aprendizagem que se manifestam na adolescência, tendo por hipótese a idéia de que esses problemas podem estar relacionados com a negação da diferença entre as gerações por parte dos adultos encarregados da educação desses jovens.

A psicanálise no senso estrito, na medida em que trata do contexto singular de um caso, pode parecer conflitante para fundamentar uma pesquisa que se propõe a fazer articulações com tendências advindas do contexto social. No entanto, minha aposta é restabelecer a relação entre o singular e o social mediante o estudo aprofundado dos dois casos. A intenção é destacar algumas questões que esses casos suscitaram, investigá-las em profundidade, na esperança de contribuir para a discussão acerca das dificuldades encontradas pelos jovens, de maneira geral, na escola. Acredito que a compreensão de certos elementos com os quais me deparo no contexto da psicopedagogia clínica pode iluminar certos aspectos obscuros na educação dos adolescentes. 
O método interpretativo da psicanálise consiste em propiciar a emergência de certos aspectos inconscientes da mente, num caso singular, visando a uma mudança subjetiva. Quando a psicanálise se estende para além dos limites clínicos, ela permite elucidar aspectos da ordem social, que também estavam latentes. Para Fábio Herrman (2005), na psicanálise extensa, o referencial psicanalítico pode ser ampliado para outros âmbitos além daquele da clínica ortodoxa. Nesse caso, a psicopedagogia clínica, de orientação psicanalítica, se situa no domínio da psicanálise extensa, uma vez que a psicopedagogia consiste em estabelecer uma mediação entre o sujeito e os objetos da cultura, tendo como fim a mudança subjetiva em face do saber.

Os dois casos que irei apresentar foram selecionados porque tratam de uma situação complexa e intrigante: apesar de haver um envolvimento e uma evolução dos jovens no atendimento, esses tratamentos foram interrompidos. De certa maneira, poderiam ser considerados malsucedidos. Justamente por isso, esses casos expõem uma dificuldade com a qual não só o profissional da psicopedagogia, como também o da clínica psicanalítica costuma esbarrar - a problemática da família ou dos pais. Nesse sentido, esse estudo pretende discutir as diferentes limitações com as quais me defronto no cotidiano da clínica psicopedagógica, mas que igualmente se apresentam aos educadores no contexto escolar.

Os estudos de casos serão discutidos à luz dos teóricos que enfrentam o problema complexo da adolescência na dita pós-modernidade. A maioria dos autores tem limitado suas análises da pós-modernidade ao exame de sua presença em contextos de países de capitalismo avançado. O fato de nos encontrarmos em um país que conjuga alguns dos efeitos mais perversos dessa pós-modernidade, com o atraso de uma desigualdade social advinda de uma herança colonial e escravista, coloca os nossos adolescentes em um contexto em que tais teorizações não os contemplam adequadamente. O fato de serem jovens oriundos da classe média não os torna imunes, como é comum se pensar, às vicissitudes, conflitos e contradições advindas de um país com tal desigualdade social, e, o que nos interessa - desigualdade educativa.

Assim, é mister examinar os casos à luz deste duplo contraponto: as questões que afetam a pós-modernidade e a particular feição que a mesma adquire em nosso país. Com isso, não queremos chegar a questões definitivas, mas a uma reflexão que possa trazer contribuições para a escolaridade do adolescente no Brasil, principalmente nos centros urbanos, além das possíveis contribuições da psicopedagogia a esse tema. 
A pesquisa se inicia no Capítulo I pela explicitação das bases teóricas que sustentam a Psicopedagogia clínica, e que referencia a minha práxis. A constituição da Psicopedagogia é correlata à idéia de fracasso escolar. Em sua origem, a Psicopedagogia se configurava como uma reeducação, situando-se entre Pedagogia e a Psicologia, e ainda buscava uma caução na Medicina. Depois de um longo processo de depuração, a Psicopedagogia acaba constituindo um campo singular, o dos problemas de aprendizagem.

Vou me deter sobre a Psicologia clínica, cujo campo é delimitado por Sara Paín (1985). Formada em filosofia na Argentina, essa autora absorve conceitos originários da Epistemologia Genética e da Psicanálise, e reconhece no aprendiz o sujeito do conhecimento e do desejo, que apresenta um sintoma e expressa, por meio do problema de aprendizagem, sua singularidade.

Em seguida, no Capítulo II, apresento os relatos de casos de dois adolescentes, abordados no âmbito da Psicopedagogia clínica. Procurei utilizar a modalidade de investigação científica dos estudos de caso, levando em conta o que fala Robert Yin (2001) partir de um contexto particular e dirigir a atenção para um fenômeno contemporâneo. A narrativa procura ser bastante aprofundada e detalhada, com o objetivo de tornar presentes todas as evidências que conferiam a complexidade de cada caso.

Os estudos de casos falam de dois adolescentes, que aqui chamarei de Fábio e Otto, provenientes de famílias de classe média, que freqüentam escolas particulares. Apesar da formação dos pais e de todo o investimento familiar, esses jovens manifestam problemas de aprendizagem. Trata-se de jovens que apresentam uma falta de autonomia na aquisição do conhecimento escolar e, também, uma grande ambivalência frente à integração escolar. Ao me aprofundar nesses casos, observo que há certa falta de discriminação do exercício da função parental; mais especificamente, um enfraquecimento dos limites, dando margem a um aumento das exigências narcísicas.

O confronto desses casos com a teoria de Sara Paín deixou algumas questões em aberto, a começar pela caracterização desses problemas de aprendizagem. Não parecia haver um sintoma na aprendizagem, no sentido de uma operação lógica estar a serviço de uma estrutura simbólica. O que havia era uma estrutura lógica prisioneira, uma diminuição da capacidade intelectiva. Além disso, esses jovens apresentavam uma recusa em se integrarem à ordem escolar. 
A partir de então, procuro destacar alguns pontos e estabelecer um diálogo com outros campos do conhecimento, no sentido de verificar se há, de fato, uma correlação entre os sintomas desses jovens e certas tendências do contexto social. O primeiro aspecto a ser estudado é o da adolescência, no Capítulo III. A narrativa dos casos acaba por explicitar um problema que parece estar articulado a uma questão específica dessa etapa de vida: a necessidade de o jovem constituir sua autonomia, mas ainda manter vínculos muito fortes de dependência com os adultos.

O referencial psicanalítico desenvolvido por Philippe Jeammet e Maurice Corcos (2005) propicia compreender que a adolescência ultrapassa, e muito, a noção da moratória social - ela corresponde a um trabalho subjetivo de grande monta, de articulação entre o mundo interno e o mundo externo. A adolescência constitui uma travessia, representada por duas tarefas desenvolvimentistas: a integração psíquica do corpo púbere e a gradativa conquista de autonomia em relação aos pais.

Esses autores mostram que o ambiente, representado pelos pais, cumpre um papel fundamental, e funciona como suporte para as ambivalências que o adolescente sente, em virtude da sexualização em relação aos vínculos parentais - ele necessita de um apoio, mas este não pode ser evidenciado. A distância relacional, o adensamento da atmosfera, os contrainvestimentos em relação às figuras paternas, constituem o ônus que os pais devem sustentar para que o jovem seja bem-sucedido na conquista de autonomia. Inversamente, o recurso à dependência é o preço que o jovem deve pagar para finalizar seu processo identificatório, necessário para a abertura para o mundo mais amplo. Nesse sentido, muitos destinos podem se traçar e daí a importância das respostas do ambiente para a organização psíquica do jovem e a efetiva conquista da autonomia.

Há casos em que os jovens apresentam uma conduta singular frente à situação de dependência - a passividade ativa -, como analisa Jeammet (2002). É uma forma de desinvestimento, de ataque aos objetos de interesse e afeto, como reação a essa situação. Trata-se da recusa escolar, como veremos no Capítulo IV.

A recusa escolar representa uma maneira de o adolescente inverter a situação de dependência e do sentimento de impotência, propiciando ao jovem a ilusão de que pode controlar seus desejos e os objetos de investimento, isto é, os pais.

A noção de recusa escolar em Jeammet parece fazer sentido para compreender a problemática apresentada por Fábio e Otto, no entanto a atitude complementar dos seus 
respectivos pais me levou a investigar mais a fundo o conceito de recusa da realidade. Esse conceito está relacionado à castração, mais especificamente, à não aceitação da castração na mãe, como diz Freud (1927). O sujeito que utiliza esse mecanismo inconsciente faz coexistir no ego duas atitudes: uma que recusa um dado da realidade e outra que o aceita. Essa forma de lidar com certas verdades nos remete aos pais daqueles jovens, que parecem recorrer a esse mecanismo em face da própria juventude e dos ideais que ela representa.

Nos casos em questão, notamos atitudes nos pais como a ambivalência diante das normas, a conivência frente à resistência dos filhos a entrar na ordem escolar e uma excessiva proximidade relacional. Essas atitudes chegam a um nível muito sério, como será possível depreender com a leitura dos estudos de casos. No entanto, situações de pseudomutualidade entre pais e filhos e a fragilização dos limites, em benefício do aumento das exigências narcísicas, têm sido cada vez mais freqüentes no cotidiano da clínica psicopedagógica e da escola. Esse tipo de situação parece estar em consonância com a denominada pósmodernidade.

Procurando fugir da armadilha de buscar uma explicação causal advinda da totalidade social para os casos particulares, a pesquisa se aprofunda, no Capítulo V, sobre o processo histórico que acabou por transformar os objetivos e as modalidades de socialização. O objetivo é destacar os elementos que configuram a ordem sociocultural e suas influências sobre as relações intergeracionais.

Gilles Lipovetsky (2006) aponta que certos preceitos da modernidade foram criticados pelo movimento modernista, resultando na lógica de personalização, que trata de uma intensificação do princípio do individualismo. Essa lógica defende a liberdade individual, a legitimação do prazer e o respeito às singularidades. Se no princípio a personalização se restringia ao meio artístico, com a revolução do consumismo esta se disseminou para todos os setores da sociedade, dando lugar à cultura narcísica.

Dentre os elementos que subjazem à cultura narcísica e que a meu ver parecem afetar as relações intergeracionais, constam a idealização da juventude, o psicologismo, a erosão das identidades e a dissolução das normas educativas, elementos que acabam por afetar tanto a sociedade, como as instituições sociais.

A etapa final da pesquisa recai sobre a família, instituição que foi atravessada por essas transformações sociais. No Capítulo VI, procuro fazer uma retrospectiva histórica da família, para compreender a evolução de sua estrutura. Elisabeth Roudinesco (2003) traça um 
painel, partindo da família hierárquica, sustentada sobre a autoridade paterna, e sua transformação ao longo de três séculos em direção a uma estrutura horizontal e igualitária.

Na segunda metade do século XX, o processo de personalização, a liberalização dos costumes, a entrada da mulher no mercado de trabalho e a revolução do consumismo transformaram por completo a configuração familiar. A relação entre pais e filhos muda completamente, dando lugar a um enfraquecimento das barreiras geracionais. A questão da autoridade, então, torna-se difícil e problemática.

O declínio das normas educativas, a perda dos parâmetros da família extensa e da comunidade, faz com que os lugares simbólicos, que antes estruturavam o núcleo familiar, sejam tomados pela indefinição. Assistimos a uma fragilização dos limites em benefício das exigências narcísicas.

O enfraquecimento dos limites constitui uma das tendências da cultura narcísica, o que adquire um caráter ainda mais agudo no Brasil, pois a ambivalência diante das normas faz parte de nossas raízes colonialistas e escravocratas (HOLANDA, 2006). Um exame mais cuidadoso de nossos padrões de sociabilidade evidencia que a lei aqui não é impessoal. Desde sua origem, ela foi criada para assegurar privilégios a poucos, e não para estabelecer direitos iguais para todos.

Dentre as heranças do nosso passado colonial, há o desejo da elite de seguir a metrópole, de se modernizar a qualquer preço. No entanto, muitas vezes esse processo se deu apenas na superfície, e não em sua base. A modernização, desde a abolição do escravismo, foi implantada, de forma arbitrária, mantendo a estrutura básica de diferenças agudas entre grupos e classes sociais. A essa base arcaica se sobrepôs um “verniz” de modernidade.

Estudando as famílias de elite e classe média, Sérvulo Figueira (1992) identifica o que ele denomina de processo de modernização reativa, que consistiu numa forma de assimilar as mudanças sociais de forma aparente, diante da dita modernização que se deu no país por volta da década de 1970. Dessa forma, as famílias pareceram modificar certas pautas que norteavam a relação conjugal e a relação entre pais e filhos, mas mantinham, em suas camadas invisíveis, valores tradicionais, próprios de uma estrutura hierárquica.

A família de classe média aderiu ao ideal do igualitarismo, pautando as relações pela igualdade. Nesse processo (de mudanças nas camadas visíveis), houve um enfraquecimento de categorias que são intrinsecamente diferentes. Em nome de uma suposta igualdade, houve o apagamento de algumas diferenças básicas, como a diferença de geração. 
A recusa escolar, nesse contexto, pode ser entendida como uma forma de o adolescente expressar suas dificuldades de fazer a travessia para o mundo dos adultos, o que, na ótica das famílias de classe média e de elite, além de desprovido de interesses, é ameaçador.

Na verdade, a recusa escolar parece constituir um pedido de ajuda, da intervenção de um adulto de fora do núcleo familiar, que estabeleça a diferença geracional e devolva o direito de usufruto da juventude àquele que de fato cabe vivê-la. 


\section{Evolução e fundamentos da psicopedagogia clínica ${ }^{2}$}

A gênese da Psicopedagogia, bem como o seu sentido, se deve à idéia de fracasso escolar. Uma retrospectiva para compreender sua origem e evolução nos leva a remontar à França do século XIX. Essa nação foi palco de dois eventos de grande importância: a implantação do Ensino Primário público, laico e obrigatório a todas as crianças entre seis e treze anos, estabelecida por meio das Leis Ferry, e a emergência de novos saberes sobre a infância (DUBET; MARTUCCELLI, 1996).

A partir da leitura das teses de Michel Foucault (1977) e a compreensão de que o poder implica a criação do saber, podemos desconfiar da idéia, comumente difundida, de que o fracasso escolar existiu desde sempre e que uma ciência foi criada para tratar desse problema. Ao contrário, foi a ciência psicológica que criou a noção do fracasso escolar.

A arqueologia do saber, utilizada por Foucault, descreve como os discursos se constituem, examinando o cenário de poder que está na origem e na alternância das formações discursivas e dos acontecimentos, como comenta Sérgio Paulo Rouanet (2000, p. 245). Portanto, na tentativa de reconstruir o cenário da emergência dos saberes que vão produzir o fracasso escolar, examinaremos brevemente a concorrência tanto dos discursos como das práticas e intervenções em torno da escolaridade que o engendraram.

É importante lembrar a influência marcante do positivismo nesse período, naquilo que Renato Mezan chamou de positivismo estrito (1998), determinando a legitimidade inequívoca das ciências na produção da verdade. O homem passa a ser o objeto de investigação, destituído de subjetividade. Georges Canguilhem, citado por Roberto Machado (1988), ilustra bem esse cenário:

O século XIX vê constituir-se (...) uma biologia do comportamento humano. As razões deste surgimento nos parecem ser as seguintes. Em primeiro lugar, razões científicas, isto é, a constituição de uma Biologia como teoria geral das relações entre os organismos e os meios, o que assinala o término da crença de um reino humano separado; em seguida, razões técnicas e econômicas, isto é, o desenvolvimento de um regime industrial orientando a atenção para o caráter industrioso da espécie humana e que assinala o término da crença na dignidade do pensamento especulativo; finalmente, razões políticas que se resumem no término da crença nos valores de privilégio social e na difusão do igualitarismo:

\footnotetext{
${ }^{2}$ Parte deste capítulo se baseia no capítulo I, "Os saberes sobre a infância - a anormalidade e o fracasso escolar", de minha dissertação de mestrado, Em busca de um sentido para a experiência escolar - histórias de crianças em escolas de elite. Dissertação apresentada na Faculdade de Educação da Universidade de São Paulo, 2003.
} 
a conscrição e a instrução públicas tornando-se problema de Estado (...) [são] o fundamento real, mesmo freqüentemente desapercebido, de um fenômeno próprio das sociedades modernas: a prática generalizada da perícia, como determinação da competência e descoberta da simulação. (ROBERTO MACHADO, 1988, p. 29)

Tendo como objeto de estudo o homem, e ainda por influência marcante de Charles Darwin, como nos lembra Carla Jatobá (2002, p. 62), assistimos, no final do século XIX, à crescente hegemonia do paradigma da evolução no campo das ciências humanas. A criança se constitui o objeto de pesquisa por excelência, visto que nela se encontraria a "gênese do homem”.

O sistema educacional republicano, destinado a concretizar a tradução, nos termos do século XIX, do ideal iluminista da Grande Revolução foi criado, aos poucos, no final do século XIX. Foi finalmente promulgado em 1881 e 1882, na França, tornando-se um modelo para os sistemas nacionais de ensino de muitas nações. Tal projeto, que pretendia formar os futuros cidadãos, veio imbuído da crença de que todos poderiam aprender, e foi marcado por um grande otimismo quanto à consecução dessa tarefa (HEBRARD, s/d).

As crianças que apresentavam dificuldades escolares, até então, não constituíam problemas que os professores não pudessem sanar, com certa paciência e habilidade docente, como comenta Jatobá (2002, p. 73). As dificuldades eram consideradas pelos professores como naturais ao processo de aprendizagem e por isso eram “incorporadas” pelos mestres. Aqueles alunos que, apesar de tudo, as dificuldades persistiam, integravam-se, sem maiores problemas, no trabalho manual, e nenhuma ajuda externa era solicitada pela escola.

A pesquisa de Carla M. R. Jatobá (2002) — Às sombras das escalas: um estudo sobre a concepção de anormalidade em Alfred Binet - discute o processo da implantação do ensino público francês, juntamente com a emergência da rede discursiva sobre a infância. Nela encontramos muitos dados que esclarecem o contexto no qual se organiza o campo das intervenções na infância com dificuldades escolares.

O fato que nos parece mais emblemático é a fundação da "Sociedade Livre para o Estudo Psicológico da Criança”, em 1899, por Ferdinand Buisson, professor de Ciência da Educação na Sorbonne. Segundo Jatobá (2002, p. 42), ela é constituída por membros do Ensino Superior, inspetores do Ensino Primário e de um grande número de professores. Alfred Binet, pesquisador da Psicologia Experimental, é convidado a participar como conselheiro científico. 
Essa Sociedade será o centro da disputa entre saberes e poderes vigentes em relação à infância. De um lado, os professores que buscavam formas de orientar seus alunos dentro de uma boa instrução moral e, do outro, psicólogos desejosos de fazer desses mesmos alunos objeto de estudo. Como demonstram Izabel Galvão e Luci Banks-Leite (2000, p. 15), essas investigações representavam uma boa oportunidade de estudo e aprendizado e, mais ainda, de reconhecimento social. Binet parecia ver nos estudos experimentais com crianças também uma forma de projeção no meio científico.

A Psicologia Experimental constituiu-se em um pólo que atraía cada vez mais adeptos, que se ocupavam do estudo da mente e do comportamento, construindo instrumentos e escalas para medir a atenção, o desenvolvimento motor, a compreensão e demais funções ligadas à aprendizagem. Binet era um expoente dessa nova ciência e via na escola um profícuo campo de aplicação das suas descobertas.

Binet dedicou todos os seus esforços no estudo da anormalidade: a investigação empírica listava as características intelectuais, morais e escolares das crianças que apresentavam qualquer instabilidade ou atraso escolar. Tal investigação cria um forte impacto quando é divulgada. Tem origem, assim, a noção de normalidade e de desvios à norma, e, gradativamente, foi prevalecendo na Sociedade Livre para o Estudo Psicológico da Criança a idéia de que nem todas as crianças podem ser instruídas.

As discussões entre os membros da Sociedade desencadeiam nos educadores uma “contaminação” do olhar psicológico sobre a criança. Aqueles alunos considerados pouco aplicados, que antes eram vistos de forma "natural”, passam a intrigar os inspetores de ensino que, a partir de então, se deixam levar pela suspeita de que, em tais alunos, reside um “anormal”.

Constitui-se, então, a noção de fracasso escolar, solidária à noção de anormalidade. Por obra do cientificismo de Binet, os educadores passam a desconfiar da capacidade desses alunos serem instruídos. Tal critério hoje é passível de crítica, apesar de soar convincente na época. Segundo Jatobá (2002, p. 55), Binet enumera fatores intrínsecos e extrínsecos à criança anormal. Dentre os fatores extrínsecos, figuram: proveniência de famílias nômades ou camponesas, ingresso tardio na escola e origem estrangeira. Em relação aos fatores intrínsecos, constam: defeitos de inteligência, lentidão de espírito, caráter bizarro e irritadiço. Podemos depreender, hoje, que tal discurso vinha embebido de preconceitos contra crianças advindas de classes populares e de atribuições moralizantes. No entanto, apesar de e por causa disso, essa postura marcou definitivamente a comunidade científica e escolar. 
Os alunos considerados anormais tinham desde então o destino já traçado: o fracasso escolar. Segundo Jatobá (2002), Binet e seus colaboradores apresentam uma solução para tal questão - a criação do ensino especial -, com a justificativa de que essas crianças eram "suficientemente inteligentes para serem asiladas e suficientemente estúpidas para freqüentarem a escola comum”. Desde então, haverá uma grande pressão da Sociedade Livre para os Estudos da Criança para isolar essas crianças daquelas ditas "normais". O esforço se volta para influenciar as autoridades de ensino para a criação das chamadas classes de aperfeiçoamento, aqui chamadas classes especiais.

Em 1909, o Ministério da Instrução Pública promulga a lei que cria um sistema escolar paralelo, destinado a crianças com patologias escolares específicas, apesar da discordância de grande parte de professores. ${ }^{3}$ No entanto, esse sistema só será implantado, talvez por resistência dos professores, a partir dos anos 50, em razão da preocupação social diante do problema de iletrismo e da democratização, na França, do Ensino Secundário. A Escala Métrica da Inteligência de Binet e Simon será o principal parâmetro na triagem dos alunos que serão integrados nesse sistema.

Embora a Psicologia Experimental defendesse uma postura científica, não podemos deixar de apontar para o caráter óbvio de exclusão social dessa triagem, visto que a maioria das crianças avaliadas por Binet, destinada a sair do sistema normal de ensino, fazia parte das camadas mais baixas da população.

A pretensa “objetividade” da psicometria de Binet encobria uma visão preconceituosa e profundamente elitista. Esse discurso retornou, no século seguinte, sob novas roupagens. O mesmo conteúdo se revela na “teoria da carência cultural”, em voga na década de 50 no meio educacional, como demonstra Maria Helena Souza Patto (1996, p. 48$52)$.

Discutindo sobre o processo histórico de produção do fracasso escolar, Souza (1999, p. 75) alerta para o fato de que a avaliação, a discriminação e, finalmente, a exclusão dos alunos com dificuldades pedagógicas não constituíram uma demanda da escola. Tais dificuldades eram consideradas inerentes ao exercício da docência e inerentes à idéia de um percurso escolar avaliado pelo "mérito" do aluno. Em suma, o fracasso escolar foi uma produção que teve sua origem nos campos da Medicina e da Psicologia.

\footnotetext{
${ }^{3}$ Carla Jatobá (2002, p. 84) faz referência à resistência dos professores tanto à avaliação de Binet quanto à proposta do ensino especial.
} 
Fazendo um balanço sobre esse processo, podemos depreender que a Psicologia, enquanto ciência, como novo saber, implicou a criação de uma rede discursiva que foi se tornando progressivamente hegemônica quanto aos saberes da infância, retirando paulatinamente, principalmente a partir da Escola Nova, a autoridade dos educadores quanto aos rumos a serem tomados pela educação. Mais ainda, essa demanda criada pela Medicina e pela Psicologia vai ser, por fim, incorporada pela escola e, desde então, a Psicologia será sempre chamada a diagnosticar as crianças que apresentam problemas que resultam em fracasso escolar.

\subsection{Intervenções acerca do fracasso escolar - a reeducação}

\section{psicopedagógica}

Os estudos de Binet atraíram muitos adeptos, que acabaram por disseminar a pedagogia experimental. Um exemplo disso é o médico suíço Edouard Claparède, que passou um ano em Paris, desenvolvendo estudos sobre a inteligência, sob a orientação de Binet. No retorno à sua cidade natal, Claparède ocupou a cátedra de Psicologia na Universidade de Genebra e publicou livros que passaram a ser leitura obrigatória dos educadores, como Psychologie de l'énfant et pédagogie expérimentale (1905) e L'École sur mesure (1921). Mas, como considera Miriam Jorge Warde (1997), é a obra Comment diagnostiquer les aptitudes chez les écoliers (1924) que desempenhou papel decisivo na afirmação da Psicologia como ciência de referência da Pedagogia, nas primeiras décadas do século XX.

$\mathrm{Na}$ formação dos educadores torna-se indispensável ter noções de Pedagogia Experimental (derivada da Psicologia) e de Psicologia da Criança. Gesta-se, assim, uma nova configuração no campo educacional. Warde (1997) demonstra a verdadeira translação que ocorrerá em torno dessas disciplinas. A Pedagogia, que até então se referenciava pela Filosofia, no novo quadro será entendida como campo de aplicação da ciência psicológica. A Psicologia, por sua vez, que antes constituía um ramo da Filosofia, emancipa-se desta e passa a filiar-se à Medicina.

A nova orientação efetua uma profunda transformação no ato educativo: “colocando a criança no lugar de objeto de conhecimento, a Psicologia deslocou do horizonte educativo o lugar de sujeito em que a filosofia iluminista havia colocado o aluno” (SOUZA, 1999, p. 78). 
A primeira notícia do termo Psicopedagogia emerge desse contexto. Ele nasce da preocupação com a educação dos portadores de deficiências sensoriais, debilidade mental e outros problemas que comprometiam a aprendizagem. Trata-se da "Psicopedagogia curativa”, proposta por Johann Pestalozzi e Édouard Séguin, de acordo com Nádia Aparecida Bossa (1993, p. 39).

Em 1930, surgem os primeiros Centros de Educação Infantil, dirigidos por médicos e formados por equipes constituídas por médicos, psicólogos e assistentes sociais. Os diferentes profissionais podiam fazer interrogações e intervenções sobre o não-aprender, mas sempre com a caução da Medicina, que ocupava o lugar central, hierarquicamente seguida pela Psicologia.

Uma nova contribuição à configuração dessas instituições vai ser inaugurada por meio da Psicanálise. Como afirma Maud Mannoni (1977, p. 63), em 1946, Georges Mauco e J. Boutonier fundam, na França, os Centros Psicopedagógicos, reunindo profissionais de Psicologia, Psicanálise e Pedagogia, com o objetivo de auxiliar crianças com problemas de comportamento e buscar sua readaptação tanto à escola como à família. Segundo Mannoni (1977), embora se tratasse de uma equipe multidisciplinar, a orientação era psicanalítica e os sintomas das crianças $^{4}$ eram compreendidos como manifestações do inconsciente, Vale marcar que essa autora reconhece que, apesar dos esforços de Mauco, questões políticas acabaram transformando tais centros em instituições dominadas pelo monopólio médico e reeducativo. Esse, entre outros motivos, leva Mannoni a fundar a escola de Bonneuil.

Em busca das raízes da psicopedagogia no Brasil, faz-se necessário voltar a atenção para a sua evolução na Argentina. De acordo com o depoimento de Alicia Fernández e Carmen Alicia Montti, ambas psicopedagogas argentinas, a Nádia Aparecida Bossa (1993), o aumento de matrículas, em face da explosão demográfica do pós-guerra e o despreparo das escolas argentinas para tal demanda, levou a um aumento do número de evasão escolar, reprovações e fracasso escolar. Dessa forma, desde 1950, aproximadamente, foi instituída a “reeducação psicopedagógica” naquele país, no sentido de atender crianças com fracasso escolar, sendo assumida por professores especializados, conforme Sonia Maria B. A. Parente (2000).

\footnotetext{
${ }^{4}$ Ao utilizarmos o termo criança, estaremos nos referindo a todos os sujeitos que estão inseridos no processo educativo, independentemente de sua faixa etária.
} 
Naquele momento, a reeducação psicopedagógica se apoiava no campo da Medicina, mais especificamente, à Neurologia; utilizava ainda os aportes da Psicologia cognitivista. ${ }^{5}$ Além de ter como alvo crianças com limitações intelectuais ou problemas de comportamento, passa a atender também uma nova manifestação de fracasso escolar: crianças inteligentes que não conseguem fazer uso dos seus recursos para aprender, isto é, alunos que estão “dentro das normas”, no entanto não aprendem. Apesar de se tratar de crianças ditas “normais”, o tratamento é o mesmo: a reeducação. A demanda por tal profissional é tão grande que se cria na Argentina o curso universitário de Psicopedagogia, por volta de 1962.

A reeducação psicopedagógica concebe a aprendizagem como o processo de construção do conhecimento, enfocando unicamente a dimensão cognitiva, do pensamento lógico. Dessa forma, ela se ocupa da instrumentalização e da ampliação da estrutura cognitiva do sujeito, levando em conta apenas fatores objetivos nos problemas de aprendizagem.

O atendimento dessa nova clientela passou a ser questionado, acusado de se tratar de uma nova prática de exclusão social, nos moldes das avaliações efetuadas pelos primeiros psicólogos franceses. Alicia Fernández, citada por Parente (2000, p. 25), refere-se da seguinte maneira àquele tipo de tratamento psicopedagógico: “corrigir ou reeducar aquilo que vinha diagnosticado pela Medicina e marcado, expulsivamente, como problema de aprendizagem pelo sistema escolar”.

Esse tipo de intervenção passou a ser questionado primeiramente pelo aspecto político da exclusão e, mais tarde, o foco de tal questionamento dirigiu-se para a questão da ética.

Bossa (1993) relata que, em 1970, se criaram em Buenos Aires os Centros de Saúde Mental, onde psicopedagogos realizavam diagnósticos e tratamentos. Esses profissionais notavam que aquelas crianças, depois de certo período, não mais apresentavam problemas de aprendizagem; contudo, manifestavam posteriormente graves traços de morbidez psíquica, como fobia, psicose etc. Para os reeducadores, esse procedimento parecia corresponder ao que Freud chamara de tratamento cosmético dos sintomas. Nas palavras de Bossa: “Os psicopedagogos tomaram consciência, então, de que haviam afogado o único grito que esses sujeitos tinham para expressar, produzindo-se, pois, um deslocamento de sintoma. A partir daí ocorre uma grande mudança na abordagem psicopedagógica” (BOSSA, 1993, p.47).

\footnotetext{
${ }^{5}$ Essa influência acabou por marcar a nova denominação desse tipo de tratamento: psicopedagogia cognitivista.
} 
Vale a pena aqui abrir um parêntese e falar sobre o contexto sociopolítico desse período. Na Argentina, como se sabe, a psicanálise é bastante disseminada e constitui-se numa linguagem comum a todas as classes sociais. ${ }^{6}$ Nos anos setenta - período de efervescência política - houve a ruptura no seio da APA, a Associação Psicanalítica da Argentina $^{7}$, dando origem ao grupo dissidente "Plataforma”. Segundo Mezan (2002, p. 223), os integrantes desse grupo viam a psicanálise como meio de transformação subjetiva, mas também como instrumento de mudança social, e procuraram ampliar os conhecimentos psicanalíticos para todos os espaços institucionais, como sindicatos, hospitais, instituições educativas, entre outros. Acredito que esse contexto de discussões e de trocas entre os psicanalistas e os profissionais da área da saúde e da educação tenha favorecido a gênese da nova abordagem psicopedagógica.

Os psicopedagogos perceberam que estavam considerando somente a dimensão cognitiva, objetiva e lógica da aprendizagem, sem contemplar a dimensão afetiva e subjetiva. Tomaram consciência de que aquelas crianças veiculavam, mediante o não-aprender, uma questão mais profunda, provavelmente relacionada à situação integrada pelo sujeito, os pais e o saber. Desde então, muitos psicopedagogos passaram a integrar em seu trabalho o olhar e a escuta clínica da Psicanálise.

\subsection{Contribuições da psicanálise à psicopedagogia}

O posicionamento crítico dos psicopedagogos que atuavam no campo dos problemas de aprendizagem dá lugar a uma revisão de seus pressupostos e à criação de uma nova forma de intervenção, que contempla igualmente a dimensão subjetiva e afetiva do aluno. Ela será denominada "Psicopedagogia clínica”, e utilizada para diferenciar-se da reeducação psicopedagógica (ou psicopedagogia cognitivista).

Nas palavras de Sara Paín, pioneira dessa nova abordagem:

A Psicopedagogia adaptativa, ${ }^{8}$ preocupada em fortalecer os processos sintéticos do ego (yo) e facilitar o desenvolvimento das funções cognitivas, pretende colocar o sujeito no lugar que o sistema lhe designou. Diferentemente, optamos

\footnotetext{
${ }^{6}$ Para conhecer mais sobre a psicanálise na Argentina, remetemos o leitor a Luis Fernando Dias Duarte: A psicanálise como linguagem social: o caso argentino. In Mana: Estudos de Antropologia Social, Vol. 8 n ${ }^{\circ}$ 2. Rio de Janeiro: Programa de Antropologia Social da UFRJ, Outubro 2002, P. 183-194.

${ }^{7}$ A APA foi a primeira Associação Psicanalítica da América Latina, sendo fundada por volta de 1942.

${ }^{8}$ Paín utiliza tal denominação com o intuito de criticar o caráter conformativo e adaptativo da reeducação psicopedagógica.
} 
por uma Psicopedagogia que permite ao sujeito que não aprende fazer-se cargo de sua marginalização e aprender, a partir da mesma, transformando-se para integrar-se na sociedade, mas dentro da perspectiva da necessidade de transformá-la. (1985, p. 12)

Sintonizada com os psicanalistas engajados nas transformações sociais, Sara Paín mostra seu posicionamento ético e político, ao postular uma psicopedagogia consoante com a dimensão afetiva do sujeito.

Na psicopedagogia cognitivista, como já foi afirmado, as referências advinham da Psicologia, da Medicina e da Pedagogia, e buscavam estimular as crianças a aprimorarem suas possibilidades cognitivas. Tais concepções se ancoram na psicologia do indivíduo, “objetivado num corpo, com suas deficiências cientificamente mensuráveis e passíveis de padronização” (SZTERLING, 2000, p. 5).

A contribuição da psicanálise se faz no sentido de acrescentar mais uma dimensão ao

olhar e a escuta do psicopedagogo: não mais à criança ou ao adolescente que apresenta fracasso escolar, como faz a psicopedagogia cognitivista, mas ao sujeito - do conhecimento e do desejo - que apresenta um sintoma e expressa, dessa forma, sua singularidade. Na psicopedagogia clínica de orientação dinâmica, de acordo com Parente (2000, p. 29), a aprendizagem está relacionada às duas dimensões do pensamento, uma associada ao sistema lógico, que lida com a objetividade, e a outra, associada aos sistemas de significação, que organiza a subjetividade. Deter-nos-emos adiante no referencial teórico de Sara Paín.

Concluindo esse percurso, podemos agora abordar a questão do fracasso escolar no Brasil, para, por fim, discutir a evolução da psicopedagogia no Brasil.

\subsection{O fracasso escolar no Brasil - as vicissitudes do processo de democratização do ensino}

Por volta da década de 70, o contexto da escola pública era crítico, agravado ainda pela configuração assumida na democratização de ensino, durante a ditadura militar, que resultou na perda de qualidade do ensino, como descreve Souza (1998, p. 75). Ainda de acordo com essa autora, o índice de repetência no Ensino Fundamental e de evasão tomava grandes proporções, dando ao fenômeno do fracasso escolar uma dimensão epidêmica. 
Discutindo a questão do fracasso escolar, Anne-Marie Chartier (2000) chama a atenção para um ponto muito importante. ${ }^{9}$ A primeira vez que se colocou em questão o fracasso escolar como um fenômeno massivo na França, foi na década de 50, por ocasião da democratização do Ensino Secundário. Os professores do chamado colégio ${ }^{10}$ depararam com alunos que não sabiam ler, não faziam uma leitura compreensiva de textos literários ou científicos. Tal fato deu margem a uma grande polêmica, pois as explicações dadas pela Psicologia, até aquele momento, não se aplicavam àquela situação.

Quando se trata de um fenômeno massivo, a Psicologia não tem uma explicação convincente. Como afirma Chartier (1995, p. 23): “a tese do déficit intelectual não pode mais ser considerada pertinente para dar conta sozinha de um fenômeno de grande amplitude”.

Chartier (2000) demonstra que explicações como essa, dadas tanto pela psicologia como por outras disciplinas, resultam estéreis, pois não levam em conta as transformações do cenário sociocultural. Quando se trata de um fenômeno de grande porte, massivo, os discursos que atribuem ao fracasso escolar uma causa individual perdem seu sentido, pois a tese de que um problema social é mera somatória de problemas individuais de diferentes tipos perdeu a credibilidade.

Procurando trazer outros elementos para compreender essa questão, a autora aponta que, no caso da França, com a democratização do Ensino Secundário, as exigências escolares e sociais em matéria de leitura se ampliaram, sofisticando seu uso tanto na escola como no mundo do trabalho. Assim, não se tratava mais de ensinar a ler um texto simples, informativo ou um questionário. A escola passou a ser solicitada a iniciar os alunos em todos os usos da leitura: sociais e escolares, utilitários e de cultura elaborada.

Portanto, se houve a democratização do ensino e da cultura, houve uma nova e mais exigente demanda social pela formação dos alunos, demanda da qual a escola ainda não se conscientizara. Logo, se houve um fenômeno massivo de fracasso escolar, visto por alguns como inadequação da escola, mais adequado seria considerar uma carência nas modalidades de escolarização, em função de um fator estrutural: as novas necessidades da sociedade pósindustrial (CHARTIER, 2000).

No caso do fracasso escolar, por volta da década de 70, no Brasil, múltiplos discursos procuravam explicar o fenômeno: o discurso sociológico, baseado nas teorias do déficit e da

\footnotetext{
${ }^{9}$ A autora fala mais especificamente das áreas da leitura e da escrita, mas podemos utilizar tal discussão para refletir sobre o fenômeno em debate e sobre as novas demandas da sociedade à escola.

${ }^{10}$ Equivalente ao nosso segundo ciclo do Ensino Fundamental.
} 
diferença cultural, como demonstra Patto (1996); o discurso médico, com a justificativa da disfunção neurológica, a DCM (disfunção cerebral mínima) e o discurso psicológico, que atribuía a esse fenômeno a causa emocional (repressão na escola, transtornos familiares, etc.).

A hegemonia da psicologia no meio educacional pôde ser percebida durante o período da ditadura militar. Como alerta Oswaldo H. Yamamoto (1996), o discurso das escolas sofreu um viés psicologizante, que consistia em restringir a reflexão sobre a educação, considerando-a apenas em seu aspecto metodológico e psíquico, deixando à margem fatores culturais, sociais e políticos. Esse viés obscureceu a visão dos educadores para os aspectos sociais do fracasso escolar. Não podemos deixar de reconhecer que há, também, um fator político, como demonstra ainda Souza (1998), pois, se a “epidemia” de fracasso escolar pode ser explicada pelo fenômeno de democratização do ensino, como afirmou Chartier (1995), ela também estava intimamente relacionada aos efeitos da massificação da escola pública. Em suma: o projeto de democratização de ensino, durante a ditadura militar, parece não ter sido concebido para ser bem-sucedido, pois foram inúmeros os aspectos negligenciados pelas autoridades governamentais: desaparelhamento das escolas, despreparo dos professores, desconsideração pelo conteúdo e o estranhamento dos novos alunos em relação aos usos e linguagem da escola. ${ }^{11}$

Assim como se passou na França e na Argentina, a Medicina e a Psicologia são chamadas a opinar e a intervir quanto ao fracasso escolar. Já havia, desde 1938, uma clínica de orientação infantil na Secretaria da Educação em São Paulo, conforme afirma Elisabete Mokrejs (1988), que mantinha uma assistência aos escolares psiquicamente desajustados. Essa clínica era dirigida por Durval Marcondes, médico psiquiatra e pioneiro da Psicanálise no Brasil, cuja orientação era a chamada higiene mental infantil. Tal clínica atendia deficientes mentais e crianças com distúrbio de comportamento, e funcionou até 1974.

Em 1964 foi inaugurado o Serviço de Psicologia Escolar, ligado à Secretaria Municipal da Educação, em São Paulo, funcionando até 1989, segundo Parente (2005). Aí era oferecido atendimento terapêutico por psicólogos aos alunos com dificuldades escolares. Diferente do caso argentino, segundo avaliações da época, as crianças melhoravam na sua sociabilidade, mas os problemas escolares permaneciam. ${ }^{12}$

\footnotetext{
${ }^{11}$ Bernard Charlot (2000a) aponta para o fato de crianças de família com pouca escolaridade não disporem de uma prática linguageira e de costumes compatíveis com o solicitado nos estabelecimentos escolares.

${ }^{12}$ Para um aprofundamento sobre o trabalho desenvolvido nesse Serviço de Psicologia Escolar, bem como a tentativa dos profissionais de reformulação e de reorientação técnica e ética segundo a psicopedagogia clínica de orientação dinâmica, remeto o leitor a Sonia Parente: Em busca da comunicação significativa: Transformações
} 
Nesse contexto, o fracasso escolar podia apresentar-se sob a forma epidêmica, o que remetia o problema a causas estruturais no sistema público de ensino; todavia, o mesmo verificou-se nas escolas particulares. Aparentemente imunes às vicissitudes pelas quais passava a escola pública, algumas crianças de escolas particulares também apresentavam dificuldades quanto à escolaridade.

Em relação a isso dois aspectos podem ser destacados: o primeiro denota uma perda de referências que as escolas sofreram - tanto a pública, como a particular. Para Souza (1998, p. 76), a massificação de ensino provocou uma perda do padrão de qualidade, antes estabelecido pelas escolas-modelo do Estado. Sem tal padrão, tornou-se difícil distinguir uma boa escola de uma escola que apenas aparenta ser boa. Assim, muitas escolas particulares passaram a investir na imagem de excelência, recrutando bons alunos por meio de exames seletivos, expulsando, eventualmente, os que posteriormente pudessem claudicar, sem se ocupar da criação de projetos que atendessem alunos em dificuldades.

Nesse contexto, verificamos certa limitação das visões e das possibilidades de intervenção das diferentes disciplinas acerca do fracasso escolar. A Pedagogia, como a principal das disciplinas que normalmente se ocupam do fracasso escolar, trata da escola e diz respeito ao ensino e à aprendizagem, e não à clínica. A Psicologia, por sua vez, ao lidar, na clínica, com a criança que apresenta problemas de aprendizagem, não incide sobre a questão do fracasso escolar.

No entanto, as análises sobre o fracasso escolar demonstraram que ele não constituía um fenômeno mecânico; como demonstra Bernard Lahire (1997), havia alunos bem-sucedidos nas classes populares e, por outro lado, alunos malsucedidos nas classes médias e superiores. Tratava-se de firmar uma questão de princípios, afeita a alunos singulares e concretos e que não podiam ser tomados como exemplos de uma regra geral, referindo-se numa regra sociológica ou numa explicação psicológica. Tratava-se, sim, de um direito da criança ou do adolescente, o de merecer uma abordagem singularizada, mesmo e, sobretudo, se seu problema pudesse ter derivações na estrutura social.

A busca por uma abordagem mais integrada do problema de aprendizagem foi encontrada na Psicopedagogia, já desenvolvida em outros países, e que representava uma tentativa de englobar esses novos enfoques e essas novas abordagens.

no olhar de uma analista na clínica da inibição intelectual. Tese de doutorado, Faculdade de Psicologia da Pontifícia Universidade Católica de São Paulo, 2005. 
Tendo em vista a demanda de uma formação sobre esse novo campo de conhecimento, em meados da década de 70, segundo pesquisa de Nádia Bossa (1993), são criados cursos de especialização de Psicopedagogia em alguns centros urbanos, como São Paulo e Porto Alegre, no sentido de complementar a formação dos psicólogos e educadores que trabalhavam com a questão do fracasso escolar. Em São Paulo, o primeiro curso, de orientação reeducativa, foi fundado no Instituto Sedes Sapientiae.

Comparando a evolução da Psicopedagogia no Brasil e na Argentina, encontramos pontos de convergência e de divergência. Um único ponto em comum está na hegemonia, em ambos os países, da Psicologia sobre a Pedagogia. Quanto aos pontos de divergência, podemos enumerar dois; o primeiro está na configuração do curso da Psicopedagogia: na Argentina, tem o estatuto de curso superior diferenciado, no Brasil, constitui num curso de especialização; outra diferença, apontada por Parente (2000): a denominação do curso de Psicopedagogia, no Brasil, não fazia referência à sua abordagem (cognitivista ou clínica). Assim, desde o início, a Psicopedagogia teve aqui uma única denominação, independente da concepção subjacente.

Em 1976, tem início ao que Manoel Tosta Berlinck (1988) chamou de “diáspora psicanalítica Argentina”: um sem-número de profissionais daquele país emigra (dentre eles muitos membros do já referido grupo Plataforma) para o Brasil, em virtude da perseguição política desencadeada pela ditadura militar argentina. Muitos psicanalistas se instalaram em São Paulo e reiniciaram suas atividades clínicas e de docência em torno do Instituto Sedes Sapientiae.

Além disso, vários psicanalistas argentinos, desprovidos dos auspícios de uma organização psicanalítica, iniciaram seminários informais, sem a filiação em instituições, dando início a um tipo de formação singular, e aqueles que neles se formaram foram denominados, por Berlinck (1988), “psicanalistas pluralistas”.

No interior do fluxo de trocas entre profissionais da área psicanalítica da Argentina e do Brasil, toma-se conhecimento do trabalho institucional integrado desenvolvido na Argentina entre psicanalistas e psicopedagogos. Naquelas instituições os problemas de aprendizagem eram tratados segundo a perspectiva da psicopedagogia clínica de “orientação dinâmica”, a que inclui no sujeito que aprende (e que não aprende) a dinâmica inconsciente.

De acordo com Parente (2005), o desejo de aprofundamento sobre os problemas de aprendizagem numa visão integrada à psicanálise leva dois grupos de educadores a 
convidarem, em 1982, Sara Paín (que estava exilada na França desde 1977), a vir ao Brasil. O convite para ministrar palestras e cursos foi realizado pelo CEVEC, Centros de Estudos Educacionais Vera Cruz, de São Paulo, e o GEEMPA, Grupo de Estudos sobre Educação, de Porto Alegre

Sua concepção dinâmica da psicopedagogia clínica parecia ampliar a reflexão sobre o fracasso escolar; não se tratava de uma sobreposição da Psicologia Genética à Psicanálise, mas de algo distinto. Paín defende uma teoria pluralista do funcionamento mental, articulando as relações entre desejo e cognição. O problema de aprendizagem, nessa concepção, configura-se com um sintoma, um obstáculo subjetivo que aprisiona a inteligência, representando uma forma de alienação que necessita ser compreendida em suas raízes.

Desde então, Sara Paín estabeleceu vínculos com diversos grupos de profissionais, em várias cidades brasileiras, sendo seguida por duas outras psicopedagogas, teoricamente filiadas a ela: Ana Maria Rodrigues Muñiz e Alícia Fernández. Assim, muitos psicopedagogos foram se formando à semelhança dos psicanalistas pluralistas, sem o vínculo institucional. Eu própria me situo nessa categoria, tendo realizado minha formação com Ana Maria Rodriguez Muñiz.

\subsection{A psicopedagogia clínica}

Cabe agora esclarecer alguns pressupostos da teoria e da prática psicopedagógica clínica, conforme Paín. Minha opção pelo aprofundamento do seu referencial está relacionada à originalidade de sua visão a respeito da aprendizagem, pois, para essa autora, a possibilidade de aprender, proporcionada pelo pensamento, depende do tipo de relação com a dimensão inconsciente do sujeito, articulada e desenvolvida em suas primeiras relações vinculares. Apesar de psicopedagoga, sua reflexão não se restringe somente à clínica; sua formação de filósofa a leva à problematização do fenômeno da “descultivação” no campo da educação, que se manifesta na desvalorização do patrimônio da cultura na contemporaneidade e na conseqüente tensão da sociedade em relação ao futuro das novas gerações. Paín vislumbra na educação uma articulação entre o passado e o futuro, como podemos apreender em sua entrevista a Leandro de Lajonquière (1996).

Sara Paín (2000) é argentina, doutora em filosofia e em psicologia pelo Instituto de Epistemologia Genética de Genebra. Sempre se ocupou da questão do conhecimento, sobretudo como este se constitui no seio do indivíduo. Em Genebra, pesquisou sobre a 
construção do conhecimento em crianças com problemas de aprendizagem, em decorrência de déficits orgânicos. ${ }^{13}$ Nesses casos, segundo a autora, é possível observar a construção do conhecimento de maneira plena, pois esse processo é mais lento.

Ao trabalhar com crianças com problemas de aprendizagem mais leves, Paín observou uma dimensão até então não percebida: a da significação que o conhecimento tinha para elas. Tal dimensão se apresentava como um obstáculo ao processo de construção do conhecimento ou como uma lacuna que parecia estar relacionada ao desejo. A partir de então, aprofunda-se na psicanálise, mais especificamente, na psicanálise lacaniana e formula, assim, “uma teoria sobre a Função da Ignorância, que dá sustentação a um campo: o das relações entre desejo (subjetividade) e cognição (objetividade) no funcionamento mental do sujeito que aprende” (PARENTE, 2000, p. 27).

Sara Paín é autora de uma obra bem ampla. Em seu primeiro livro publicado no Brasil, Diagnóstico e tratamento dos problemas de aprendizagem (1985), ela propõe uma diferenciação entre “problema escolar” e “problema de aprendizagem”. O primeiro está relacionado à instituição educativa que rejeita ou desconhece a verdadeira capacidade intelectual e lúdica da criança ou do adolescente, e provoca nela, reativamente, a inibição mental e expressiva. Segundo Fernández (1990, p. 49), esse problema é um fator externo ao aluno e ao grupo familiar, pois se refere, mais especificamente, à instituição escolar. No segundo caso, trata-se do problema de aprendizagem, manifestado de duas formas: "problema de aprendizagem como sintoma” - algo de ordem subjetiva que afeta a inteligência, não permitindo que o sujeito explore todas as suas possibilidades na relação e na apropriação do objeto de conhecimento; a "inibição intelectual” ou "oligotimia”, que corresponde a uma retração da função cognitiva. Nesses dois casos, o problema seria um fator interno ao grupo familiar e à criança ou ao adolescente.

Dessa forma, Paín busca delimitar os campos: o problema escolar, que diz respeito à escola, deve ser tratado no interior do espaço escolar; e o problema de aprendizagem deve ser tratado em outra esfera - a da clínica da Psicopedagogia. A autora - citada por Leandro de Lajonquière, esclarece:

As patologias do aprender devem ser curadas fora da escola. A escola é um lugar de aprendizagem e não de terapia (...) O campo terapêutico possui uma outra dialética, diferente da escolar. O terapeuta não ensina; ao contrário, dedica-se a pensar quais são os obstáculos no aprender para assim poder dissolvê-los. (1996, p. 99)

\footnotetext{
${ }^{13}$ Trata-se de casos denominados por oligofrenia.
} 
Sara Paín também faz menção à “oligotimia social”, que consistiria em um sintoma social. A oligotimia social refere-se a uma sociedade na qual as instituições produzem sujeitos com uma atividade cognitiva empobrecida, mecânica e passiva, aquém das suas possibilidades reais. Paín alude ao período da ditadura militar em seu país e alerta para a possibilidade de isso ocorrer em outras sociedades capitalistas, retomando aqui um tema caro aos filósofos da Escola de Frankfurt.

O termo oligotimia foi cunhado inicialmente por Enrique Pichón-Rivière. Na Psicopedagogia esse termo se refere ao sujeito inteligente que funciona aquém das suas possibilidades, como no caso da inibição intelectual. Para Parente (2000, p. 76), trata-se de uma questão afetiva que cria obstáculo à atualização do potencial intelectual. Conforme Paín (1985, p. 28), tal problema deve ser entendido como "um estado particular de um sistema que, para equilibrar-se, precisou adotar este tipo de comportamento que mereceria um nome positivo, mas que caracterizamos como não aprendizagem”.

Paín (2000, p. 42) recorre a Freud para esclarecer no que consiste o sintoma na aprendizagem. Na análise do caso de uma histérica que antes segurava a cabeça do pai doente e depois apresenta paralisia do braço, Freud interpreta tal sintoma pelo desejo inconsciente da jovem de deter o curso do tempo, no sentido de manter o pai vivo. Pois bem, aquilo que ocorre no caso da histeria entre o organismo e o campo da significação simbólica é análogo ao que se passa no caso da aprendizagem. Ou seja, no problema de aprendizagem, os mecanismos lógicos e as operações mentais, que deveriam servir para construir a objetividade, são desviados para construir a subjetividade. Assim, uma operação lógica pode ser tomada por uma configuração simbólica e passar a representar outra coisa.

Para Paín (1996, p. 16), há uma cisão no funcionamento mental: de um lado, há uma estrutura lógica, que se ocupa em construir conhecimentos, e de outra, há uma estrutura simbólica, que trata de fabricar fantasias. Não se trata da dicotomia clássica que separa o inconsciente da consciência, isso levaria a concluir que o conhecimento se constrói no nível consciente e o desejo se dá no inconsciente. Ao contrário, não temos acesso ao processamento do conhecimento, mas sim, de seu resultado; é por meio do produto do pensamento sobre a realidade que se pode teorizar sobre seu processo.

O conhecimento (o pensamento dirigido para a realidade), para Paín (1996, p. 23), é tão inconsciente quanto o pensamento voltado para o desejo. Assim, a autora propõe uma cisão no domínio comum da produtividade inconsciente, de forma que as duas estruturas 
funcionam de forma independente, e a saúde do sujeito consiste exatamente na separação das duas dimensões da construção do pensamento.

No funcionamento mental (inconsciente) há a dimensão cognitiva e objetivante, separada da dimensão simbólica e subjetivante. As duas se diferenciam por sua construção, cada uma delas tem operações e mecanismos próprios. ${ }^{14}$ As operações utilizadas na estrutura cognitiva são diferentes das utilizadas na estrutura subjetiva, "embora os conteúdos sejam solidários e intercambiáveis”, de acordo com Paín (1996, p. 40). O sintoma do problema de aprendizagem advém de uma metaforização de uma operação lógica.

Um exemplo disso, advindo da minha própria experiência clínica, se deu com uma menina de nove anos. Ela apresentava dificuldades em matemática, mais especificamente, na adição. Para ela, essa operação mental perdeu a sua dimensão lógica e adquiriu um significado de ordem subjetiva. No diagnóstico, verifiquei que seu pai (que era divorciado) tinha um segredo em relação à sua vida sexual. Nesse caso, para a menina, juntar coisas (percepções, informações, e até mesmo números) representava algo perigoso, pois isso poderia vir a desestabilizar um aparente equilíbrio na família. Daí a função do não saber. Segundo Paín (2000, p. 59), ocorreu uma "transformação simbólica das operações, aquisições das capacidades objetivantes nos significantes subjetivos”.

Visto que no sintoma do problema de aprendizagem há uma invasão dos limites entre as duas estruturas do funcionamento mental, faz-se necessário conhecer as teorias que fundamentam cada uma delas: a Epistemologia Genética, do lado cognitivo, e a Psicanálise, do lado subjetivo. A primeira auxilia na compreensão do sintoma: na verificação de quais instrumentos estão falhando; a psicanálise auxilia na interpretação do mesmo: entender por que o sujeito não faz um bom uso dos seus instrumentos.

Assim, é necessário um duplo olhar e uma dupla escuta, verificando as relações entre a dimensão cognitiva e afetiva, para compreender o universo em que se inscreve o sujeito e a significação que o não-aprender adquiriu para ele.

Segundo Parente (2000), o problema de aprendizagem gera um campo singular de relações do sujeito com a realidade e com o objeto de conhecimento, e é a partir da observação e compreensão desse campo que o psicopedagogo pode ajudar a criança ou o

\footnotetext{
${ }^{14}$ Remetemos o leitor às obras de Sara Paín que se aprofundam sobre as estruturas do funcionamento mental: $A$ função da ignorância. Porto Alegre: Artes Médicas, 1987, Vol. 1 e 2, e Subjetividade e Objetividade: Relações entre desejo e conhecimento. São Paulo: CEVEC-Centro de Estudos Educacionais Vera Cruz, 1996.
} 
adolescente a ocupar um outro lugar, onde possa alcançar uma aprendizagem que constitua uma realização e algo com significado.

Para se aprofundar no campo das relações da criança com a realidade e o objeto de conhecimento, faz-se necessário realizar um diagnóstico psicopedagógico, cuja finalidade é encontrar uma funcionalidade para o sintoma, a sua articulação na situação integrada pela criança ou o adolescente e pelos pais.

Vale marcar que uma série de fatores influencia a aprendizagem: organismo, corpo, inteligência, desejo e cultura. Eles intervêm simultaneamente nos processos cognitivos e na aprendizagem e, portanto, "na constituição das perturbações da função da inteligência e da aquisição dos conhecimentos”, segundo Paín (2000, p. 59). De alguma maneira, o diagnóstico deve propiciar a observação dessas variáveis no ato de aprender do sujeito.

Como comenta Sara Paín (2000, p. 50), o termo diagnóstico, como processo de pesquisa, tem “péssima reputação”. Esse termo parece referir-se ao grau máximo de objetividade, no entanto estamos tratando de um sujeito, com suas idiossincrasias. É importante observar que, apesar de a Psicopedagogia tomar emprestados termos da Medicina e da Psicologia, sua abordagem é bastante distinta. Não se trata de mais uma abordagem que coloca a criança ou o adolescente no lugar de objeto; tal procedimento os vê na perspectiva da sua subjetividade.

A necessidade do diagnóstico se justifica pelo fato de necessitarmos conhecer o sujeito por meio de suas condutas, seu discurso e da história que nos é revelada por ele e seus pais. É verdade que esse momento corresponde ao início do processo com a criança ou o adolescente, no entanto o atendimento também é acompanhado dessa atitude de pesquisa (própria do diagnóstico), pois, ao longo do tratamento, nos ocupamos em compreender certos elementos significativos da fala, da ação do sujeito, de suas produções. O diagnóstico também é necessário, pois é por meio dele que o psicopedagogo estabelece um projeto de trabalho.

Assim, no diagnóstico psicopedagógico são considerados os diferentes aspectos que circundam o universo da criança ou do adolescente. Na primeira esfera situam-se os fatores que se referem ao sujeito e à sua família: pesquisa-se o histórico do sujeito, o significado que o seu desenvolvimento e os acontecimentos vão tomando para os seus pais. O objetivo é primeiramente verificar o lugar que a criança ou adolescente ocupa no grupo familiar, pois isso se relaciona ao reconhecimento do filho em relação aos pais. Isso nos leva à triangulação 
edípica, ${ }^{15}$ ao lugar que o saber ocupa na família e, finalmente, às formas de comunicação no grupo familiar.

Em uma segunda esfera, abordam-se a relação da criança ou do adolescente e o objeto de conhecimento, tanto do ponto de vista do sujeito que se apropria do conhecimento, como do sentido e dos afetos que esse conhecimento representa para o sujeito. ${ }^{16}$ Pesquisa-se a modalidade de aprendizagem da criança ou adolescente e, por fim, os recursos do sujeito para apropriar-se dos objetos de conhecimento. O que se busca, nessa esfera, é verificar a relação singular do sujeito com o conhecimento e o sentido da aprendizagem para ele.

É importante marcar que, no que diz respeito ao sujeito, ele deve ser considerado na sua dupla vertente, como comenta Jorge Gonçalves da Cruz (1990): o sujeito do conhecimento (epistêmico) e o sujeito do desconhecimento - desconhecimento do seu desejo, daquilo que o sintoma fala. Nesse sentido, no diagnóstico, há certas formas objetivas de se conhecer o primeiro, ao passo que o sujeito do desconhecimento, ou o sujeito do inconsciente, não é, por definição apreensível diretamente, mas se revela por meio dos lapsos, do sintoma. Daí a necessidade da dupla escuta do psicopedagogo. Vou relatar a seguir como se dá essa parte do diagnóstico.

\subsection{Diagnóstico psicopedagógico com o adolescente}

Costumo iniciar o diagnóstico com uma conversa com o adolescente, procurando verificar se ele sabe por que veio ao consultório de psicopedagogia, se sabe o que é isso. Geralmente os jovens sabem que vieram por suas dificuldades escolares, mas imaginam que vieram a uma espécie de aula particular ou a um tipo de atendimento psicológico. Procuro explicar no que consiste o atendimento em psicopedagogia e, em seguida, relato algumas das dificuldades que os jovens costumam ter, para possibilitar uma identificação do sujeito ou até mesmo uma conscientização do seu problema. É interessante observar qual é a fantasia que o jovem traz sobre sua dificuldade - muitas vezes nega a dificuldade, ou, outras vezes, a atribui a uma mudança de escola, de cidade, ou a uma doença que teve. Nesse sentido, é possível verificar o quanto o sujeito se implica no próprio problema de aprendizagem.

\footnotetext{
15 Mesmo quando tratamos de adolescentes, a questão edipiana se faz presente, uma vez que a puberdade confronta o jovem com uma nova demanda pulsional que o leva à revivência do conflito edipiano e, com ela, à defrontação com seus desejos incestuosos.

${ }^{16} \mathrm{O}$ conhecimento pode tomar inúmeras representações para o sujeito: algo perigoso, ou, ao contrário, algo prazeroso, entre outros exemplos.
} 
Em seguida, proponho ao adolescente a EOCA, "Entrevista centrada na aprendizagem”, proposta por Jorge Visca, ${ }^{17}$ em que se solicita ao sujeito que mostre uma coisa que aprendeu, fazendo uso de um material do tipo escolar, e assim, sucessivamente, até representar três coisas aprendidas. O objetivo é estabelecer um contato com o sujeito por meio de uma tarefa que versa sobre o seu processo de aprendizagem. Interessa observar os conhecimentos escolhidos pela criança ou pelo adolescente, a atitude frente à tarefa, os sentimentos manifestos durante a situação, as ansiedades, bem como a modalidade de aprendizagem do sujeito.

Nessa entrevista, o psicopedagogo tem a oportunidade de observar a temática que o sujeito traz: o que o parece mobilizar quando se trata de aprendizagem. Há crianças e adolescentes que mostram coisas que aprenderam com os amigos na rua, que aprenderam no clube, enfim, muitos não tocam na experiência escolar. Também observo aspectos da dinâmica (inconsciente), a qual, para Visca (1985), manifesta-se por meio dos elementos nãoverbais - os gestos, os silêncios, as hesitações, a forma de lidar com o material etc. Por fim, observo o produto, tanto no que diz respeito ao conteúdo escolhido, como a sua forma, se a representação foi bem elaborada ou não, se tem muitas rasuras etc. No que diz respeito ao produto, é possível depreender a relação do sujeito com sua produção - se ele se reconhece ou não no que realiza, se gosta do que produz ou não etc. A partir desses elementos, é possível levantar algumas hipóteses sobre o problema de aprendizagem, que irão se confirmando ou não ao longo do diagnóstico.

Um dos principais aspectos que procuro observar no diagnóstico é a modalidade de aprendizagem do sujeito. Por modalidade de aprendizagem se entende a forma singular de o sujeito aproximar-se do conhecimento e configurar o saber. Cada um tem uma forma peculiar de aprender, como se fosse uma matriz que o sujeito guarda consigo e a utiliza na interação com a realidade.

Paín (1985) propôs esse conceito com base na teoria da adaptação inteligente de Jean Piaget. O autor aponta os dois mecanismos que o sujeito lança mão, o da assimilação, que implica na capacidade de o indivíduo construir o mundo de acordo com os próprios esquemas, e o mecanismo da acomodação, complementar ao primeiro, que implica na transformação dos próprios esquemas para adequá-los em função das exigências externas. A adaptação do sujeito

\footnotetext{
${ }^{17}$ Atividade proposta por Jorge Visca, em Clínica Psicopedagógica. Epistemologia convergente. Buenos Aires: Miño y Davila, 1985. O material consta de lápis, canetas, tesoura, régua, livros técnicos - dicionário, atlas - e livros de literatura, papel sulfite, papéis coloridos, papel quadriculado, cartolina, cola, durex, clips, etc.
} 
ao meio implica um equilíbrio entre os dois mecanismos. Como comenta Paín (1992), o mesmo se passa na atividade mental.

Para aprender a ler e escrever, por exemplo, precisamos identificar e conhecer as letras para formar as palavras, a fim de nos comunicarmos pela escrita. Temos aqui o predomínio do mecanismo da acomodação. No entanto, na própria escrita, podemos utilizar o código de forma singular, por meio de uma produção mais divergente, marcando a nossa subjetividade, como no uso das metáforas. Nesse caso, o predomínio é do mecanismo de assimilação. Nos atos inteligentes, desde o bebê, com os esquemas sensórios motores, até o adulto, com o pensamento formal, há os dois movimentos.

Paín (1985) propõe a constituição de diferentes modalidades nos processos representativos e os extremos são caracterizados pela predominância de um mecanismo sobre o outro, como a modalidade de aprendizagem hiperassimilatória, em que há uma primazia da subjetivação - o predomínio da submissão dos objetos aos desejos do sujeito. ${ }^{18}$

Uma das formas de observar a modalidade de aprendizagem, bem como de nos aprofundarmos sobre as significações que o aprender tem para o sujeito, é por meio do desenho do Par Educativo. ${ }^{19}$ Nesse desenho, solicitamos que a criança ou adolescente represente alguém ensinando e alguém aprendendo. O sujeito representa uma situação de aprendizagem e, de forma geral, coloca na folha de papel aspectos da sua relação com a aprendizagem.

No desenho do Par Educativo, assim como em outros desenhos que proponho ao jovem, é possível observar os recursos cognitivos que o sujeito foi construindo ao longo da sua experiência: o uso da perspectiva, a simetria, as relações topológicas, a percepção de que algumas partes ficam ocultas, como as pernas sob as calças compridas, entre outros elementos.

É necessário levar em conta os recursos cognitivos, orgânicos e corporais do sujeito no ato de desenhar, mas também o uso que ele faz desses recursos. Outro elemento é o fator subjetivo da escolha para a forma dos objetos representados - uma pessoa deitada, uma caixa fechada etc. O sujeito do desconhecimento se revela por meio das omissões, das substituições, das rasuras, da sua argumentação sobre a própria produção.

\footnotetext{
${ }^{18}$ As modalidades de aprendizagem propostas por Paín (1985, p. 47) são: hipoassimilação, hiperassimilação, hipoacomodação e hiperacomodação.

${ }^{19}$ Remeto o leitor a Maria de Fátima Marques Gola, "Instrumentos psicopedagógicos para o conhecimento do sujeito que não aprende”. Revista de Psicopedagogia. 18(49), 1999.
} 
Como lembra Fernández (1990, p. 225), nas produções gráficas a atenção do psicopedagogo recai mais sobre o processo de realização do desenho do que sobre o produto. É interessante verificar o método utilizado pelo adolescente, as verbalizações, a atitude corporal, o tempo dedicado à atividade, o envolvimento durante o desenho.

Uma das oportunidades mais ricas de se conhecer o sujeito e sua relação com a aprendizagem é por meio do jogo. No jogo o sujeito faz uso do pensamento e também de seu potencial criativo. O espaço do jogo e o espaço da aprendizagem são análogos. Com adolescentes, proponho um jogo lógico, individual ou coletivo, com o fim de observar diversos aspectos: o tipo de relação do sujeito com o objeto; se o jovem o reconhece em sua própria legalidade; se ele o utiliza adequadamente; se ele faz o inventário, isto é, se observa todos os elementos que compõem o jogo; se ele se submete à sua estrutura, sua regra de funcionamento, entre outros elementos.

Alicia Fernandez propõe uma pauta de aspectos para serem observados, ${ }^{20}$ dos quais selecionarei aqueles que julgo oportunos neste caso:

a modalidade de aprendizagem, a disponibilidade corporal, o grau de prazer presente no jogo, (...) as fraturas do discurso lúdico (as repetições, os cortes), (...) os esquemas de ação que se repetem, o grau de correlação entre o discurso verbal e o corporal, (...) a presença de alguns significantes que remetem às idéias inconscientes sobre o aprender, (...) as estratégias propostas em jogo para resolver os problemas que se lhe apresentem, já que os processos e não os resultados obtidos, são os que permitem inferir a dinâmica, a gênese, as possibilidades atrapadas e as disponíveis, e o acionar do organismo, do corpo, da inteligência e do desejo. (1990, p. 177)

Vale assinalar que o uso que faço de qualquer instrumento - de avaliação ou de intervenção - sempre leva em consideração essa dupla dimensão. Procuro dialogar com o sujeito do conhecimento, levando-o a analisar sua produção, mas também observando lapsos, silêncios, omissões, que podem fornecer pistas para a interpretação do que Fernandez (1990) chama de sujeito do desconhecimento.

Em relação ao sujeito que Piaget chama de "epistêmico", no diagnóstico, procuro observar a inteligência em ação - a estrutura lógica do pensamento e como o sujeito a disponibiliza - por meio de situações-problema, jogos, desenhos e as provas piagetianas, que dão base para a realização do que se denomina o Diagnóstico Operatório.

\footnotetext{
${ }^{20}$ Essa pauta é proposta acerca da hora de jogo psicopedagógica para crianças até 9 anos, que é inspirada na hora de jogo lúdico, embora com materiais não-figurativos.
} 
O uso de um instrumento padronizado, como o diagnóstico operatório, poderia incorrer em desvios, converter o sujeito em objeto de mensuração, de rotulação e até mesmo de exclusão, como vimos. Esse tipo de desvio ocorre quando se suprime a escuta ao sujeito. Como comenta Jorge Gonçalves da Cruz (1990), “prescindir destas provas não nos 'vacina automaticamente' contra erros iatrogênicos ${ }^{21}$, que não são inerentes a esse instrumento, menos ainda exclusivos do mesmo”.

O autor se refere a Maud Mannoni, cuja citação vamos ampliar:

Os "testes" são para mim um meio e não um fim. Utilizo-os num diálogo, durante o qual procuro apurar um sentido, um sentido, sem dúvida, em função de certo esquema familiar. (...) Depois de tudo, nunca será demais repetir , um "teste" deveria ser compreendido como um ensaio (com suas possibilidades de erro) e não como um texto legislativos que ordena esta ou aquela orientação. (1985, p. 84-85)

Por fim, vale lembrar que a escolha do instrumento diagnóstico nunca é neutra, por isso, como recomenda Cruz (1990), faz-se necessário conhecer e explicitar o marco teórico em que o instrumento se insere, ser coerente no uso e nos objetivos em relação aquele marco teórico, e, é claro, conhecer bem o instrumento em questão.

Apesar de consistir num instrumento padronizado, o diagnóstico operatório basicamente é um diálogo com o sujeito, de forma sistemática. Esse diálogo, que se dá a partir das respostas do sujeito - logo há a abertura para o adulto fazer novas perguntas e criar novas contra-argumentações - , abre-se para o imprevisto, tanto para o adulto, como para o sujeito. ${ }^{22}$ Na verdade, nessa prova, verifica-se o potencial cognitivo e criativo do sujeito.

A forma como Piaget construiu esse instrumento já revela que sua intenção estava longe de avaliar para rotular ou mesmo excluir. Como relata Juan Delval (2002), em 1919, Piaget, logo após seu doutorado de Biologia, foi a Paris, onde trabalhou no laboratório de Binet. Lá recebeu a tarefa de realizar a padronização dos testes de raciocínio de Burt para a população infantil de Paris. Piaget aceitou a proposta e, ao realizar os estudos para a padronização, verificou que, mais interessante do que avaliar os acertos, era estudar a natureza dos erros das crianças.

De volta à Suíça, Piaget desenvolve estudos em que estabelece diálogos da mesma forma que a entrevista clínica, no sentido de verificar o raciocínio subjacente às respostas das

\footnotetext{
${ }^{21}$ Iatrogenia diz respeito a atos ou pensamentos da conduta médica, e iatrogênico diz respeito a doenças ou desvios derivados de práticas médicas equivocadas.

${ }^{22}$ Muitas crianças e adolescentes têm verdadeiros insights nessa prova, quando são levados a formular hipóteses sobre diferentes fenômenos.
} 
crianças. Aos poucos, foi formalizando essas pesquisas e criou o método clínico de investigação na área da psicologia do desenvolvimento.

O Diagnóstico Operatório, de acordo com Juan José Conte MacDonell (2004), é constituído de algumas provas clássicas de experimentação em Psicologia Genética e tem como fim verificar o grau de aquisição de algumas noções-chave para determinar a estrutura lógica do sujeito e com que elementos ele conta para reconstruir e organizar o universo mentalmente. Em suma, algumas noções, como a conservação de massa, de peso, de volume, entre outras, são categorias lógicas que consistem em balizas para compreender o mundo.

De acordo com Paín (2000, p. 131), a inteligência organiza o universo na forma de objetos permanentes. Essas aquisições possibilitam compreender o mundo em sua constante transformação, no entanto, apesar da aparente mudança, há algo que se conserva, que permanece. Isso é importante tanto no sentido objetivo, para entender os diferentes fenômenos físicos, como no sentido subjetivo. Isso vale para a percepção da própria identidade ${ }^{23}$; apesar das transformações do corpo no tempo (sobretudo na adolescência), o sujeito continua sendo o mesmo, ou ainda, apesar de novas referências identitárias, há um núcleo que se conserva e pelo qual o sujeito se reconhece.

Quando trabalho com adolescentes, costumo utilizar as provas piagetianas de pensamento formal, propostas por Longeot e sistematizadas por Lino de Macedo (1983). Essas provas fornecem pistas para o conhecimento da estrutura da inteligência do sujeito, a etapa em que esta se encontra, mas a riqueza das mesmas consiste em verificar a qualidade das explicações causais, isto é, qual o argumento que o jovem utiliza para explicar os fenômenos físicos ou problemas formulados em termos de proposições formais.

A intenção é entrar em contato com o sujeito do conhecimento, por meios dos argumentos que o adolescente sujeito vai tecendo. Também temos a oportunidade de observar as fraturas no discurso, certas fixações, que dizem respeito ao sujeito do desconhecimento e que indicam a natureza dos prováveis obstáculos subjacentes ao pensamento e às resistências que interferem na sua estrutura operatória.

Ao final do diagnóstico, proponho uma atividade de leitura e escrita para observar os recursos específicos de que o adolescente dispõe para se apropriar e interagir com o conteúdo escolar. Solicito a leitura de um artigo de jornal, ou de um pequeno conto, e proponho em seguida uma atividade de paráfrase: o sujeito reconta o texto à sua maneira ou faz um

\footnotetext{
${ }^{23}$ Piera Aulagnier (1990) discute os dois princípios do funcionamento identificatório: permanência e mudança.
} 
comentário por escrito sobre ele. Essa atividade possibilita verificar a aproximação do sujeito com a aprendizagem escolar e também consiste numa situação em que se pode detectar um distúrbio específico de linguagem, fator que merece um encaminhamento para um especialista da área.

Chegamos, por fim, à terceira esfera do diagnóstico psicopedagógico. Trata-se do significado da cultura para a família, cultura também representada pela escola. Verificaremos, então, que opções são feitas nesse sentido (sobretudo ideologicamente) e que mensagens são veiculadas para o sujeito em relação ao ato de conhecer. Pesquisamos quais são os valores do grupo familiar e como estes são transmitidos. Assim, o psicopedagogo vai tecendo o fio que leva ao sentido que o não-aprender representa no triângulo edípico.

Como afirma Chartier (1995, p. 24), qualquer que seja a origem do problema de aprendizagem, o que é mais significativo é o modo como o sujeito e, sobretudo, os pais e a escola vivem esse acontecimento. Isso acaba prevalecendo na constituição ou na superação de tal sintoma.

Uma vez levantadas as hipóteses sobre a funcionalidade do sintoma, cabe relatar aos pais o processo do diagnóstico e oferecer um espaço de troca, de reflexão sobre o problema de aprendizagem da criança ou do adolescente. A intenção é proporcionar um momento em que os pais possam, de acordo com Fernández (1990, p. 30), ver-se a si mesmos individualmente, mas também como casal e como uma família. É interessante que possam diferenciar-se, mas também perceberem seus laços e alianças. Nesse momento, temos a oportunidade de verificar a possibilidade de aprendizagem dos pais: a forma como se aproximam daquele problema, o quanto se percebem fazendo parte daquela situação e, sobretudo, sua disponibilidade para se transformarem.

O problema de aprendizagem pode ser significado como uma denúncia, não só da forma de funcionamento do grupo familiar como também do sistema educacional ou da escola que a criança ou adolescente freqüenta. Se, de um lado, ele consiste em uma denúncia, por outro lado representa uma renúncia por parte do sujeito.

Assim, o trabalho psicopedagógico deve apontar para ambas as orientações, no sentido de não ficar centrado sobre a instrumentalização do sujeito, a fim de adaptá-lo à escola e à sociedade, e "sim promover nele um máximo de independência e autovalorização, bem como a realização de uma sociedade na qual seu problema não seja possível”, nas palavras de Paín (1985, p. 75). 
Resta esclarecer como se dá o tratamento psicopedagógico, tendo ainda como base Paín (1985, cap. 7).

\subsection{Tratamento psicopedagógico}

O tratamento é "sintomático", o trabalho clínico é centrado no sintoma, no sentido de possibilitar ao sujeito fazer uso dos seus recursos e interagir com os objetos de conhecimento. Segundo Paín:

Diz Freud que o que resta da doença, depois da desaparição do sintoma é apenas a disposição para formar novos sintomas; entretanto quando se trata da aprendizagem e das atividades cognitivas, o reforço destas deixa o sujeito numa melhor disposição para elaborar seu trauma, caso se submeta a uma psicanálise, e para encontrar vias de satisfação e sublimação na vida quotidiana. (1985, p. 77)

Apesar de se tratar do sintoma de aprendizagem, a intervenção não tem um fim “corretivo”. O que se busca é devolver à criança ou ao adolescente, ao longo do processo, a dimensão de seu poder: poder escrever, poder pensar, poder criar etc.

O tratamento é "situacional”, baseia-se naquilo que transcorre durante a sessão. Como já afirmamos, o enquadre reforça o vínculo da criança ou do adolescente com a tarefa e não com o psicopedagogo, que se configura como testemunha do processo do sujeito.

O tratamento é “operativo”, ${ }^{24}$ a relação é feita principalmente com uma tarefa precisa e concreta, que pode partir do sujeito ou do adulto, como um jogo, uma atividade plástica, a leitura de um livro etc. A tarefa não tem como fim ensinar algo ao sujeito. O que se busca é devolver-lhe o interesse pelo conhecimento, o interesse em ser agente de uma ação inteligente. O objetivo do tratamento é inseri-lo no mundo da cultura, de forma que ele possa transitar com autonomia nesse universo.

Nesse sentido, como já foi afirmado, é necessário ter conhecimentos da Epistemologia Genética, pois o trabalho se faz à maneira do método clínico de Jean Piaget. São propostas situações de aprendizagem nas quais a criança ou o adolescente se depara com desafios de acordo com o seu nível de pensamento e o sujeito é levado a fazer suas próprias descobertas. A partir de então, criam-se novas situações que possam levar o sujeito a constituir formas mais elaboradas de pensamento.

\footnotetext{
${ }^{24}$ No sentido que Enrique Pichon-Rivière empresta ao termo.
} 
O tratamento é “clínico”, de forma a acompanhar a criança ou adolescente e não de reeducá-lo. O conhecimento da psicanálise também é necessário, pois na intervenção fazemos uso de alguns aportes da Psicanálise, como a escuta do sujeito do desejo, o assinalamento de fatos significativos: o sentido da operação omitida ou, então, o procedimento equivocado, procurando revelar ao sujeito suas próprias "armadilhas”. A maioria das intervenções tem por objetivo explicitar verbalmente as variáveis que constituem as situações de aprendizagem, buscando levar o sujeito à tomada de consciência de suas ações e das relações que estabelece em tais circunstâncias.

É necessário reconhecer que a origem do problema de aprendizagem provavelmente não seja resolvida, mas pode haver uma transformação, tanto na manifestação de um outro sintoma, como na formulação do pedido pela criança ou pelo adolescente de um atendimento psicoterapêutico. Vale marcar que não se trata daquilo que Bossa (1993) comentou anteriormente sobre deslocamento de sintoma por uma falta de espaço para as questões subjetivas, pois na psicopedagogia clínica há uma escuta e muitas vezes certas intervenções do profissional diante de tais questões.

O que julgo importante é possibilitar a liberação das capacidades cognitivas do sujeito, até mesmo para poder se beneficiar de uma psicoterapia. Como afirma Paín: "Não se trata de garantir um 'sucesso social', nem de forçar uma 'adaptação', mas de dar à pessoa suas capacidades e o prazer perdido de conhecer” (2000, p. 52).

Basicamente, os objetivos do trabalho são: alcançar uma aprendizagem que consista numa gratificação para o sujeito, a conquista da autonomia na inserção no mundo da cultura e a realização de uma produção com a qual o mesmo se reconheça por meio dela. O desempenho escolar não é uma preocupação imediata do trabalho, uma vez que, segundo Paín, “o único conhecimento válido é o que foi processado pelo sujeito, o que consta como uma experiência pessoal, o que se adscreve ao total da sua memória” (1985, p. 81).

Essa questão é esclarecida aos pais e à escola, explicitando-lhes que o objetivo é devolver à criança ou ao adolescente o interesse pela aprendizagem e a possibilidade de poder ser sujeito na interação com os objetos da cultura. Assim, ao longo do trabalho, o mesmo tem experiências que constituiriam matrizes para as futuras aprendizagens, o que costuma ocorrer, posteriormente, na situação escolar.

Portanto, a intervenção psicopedagógica tem como fim a inserção do sujeito no universo da cultura, no mundo das trocas simbólicas. Acredito que, por meio da fruição e da 
atividade cultural, a criança ou o adolescente tem a oportunidade de estabelecer novos laços sociais. Ao encontrar novas referências, poderá ultrapassar o universo da família, vislumbrando, assim, novas formas de expressar sua singularidade, diferentes das que encontrava no sintoma. Desse modo, constrói um sentido para sua trajetória pessoal, nela incluindo a experiência escolar.

A intervenção psicopedagógica acontece mediante um trabalho individualizado com a criança, geralmente duas vezes por semana. Há trocas regulares com os pais, para conscientizá-los de sua participação no sintoma do filho, ajudando-os a criar novos espaços de expressão para ele. Essa troca também visa a colher informação sobre as transformações que eles vão observando na criança ou no adolescente ao longo do tratamento. Observações que podem nos orientar na condução do tratamento. Trata-se de uma importante dimensão do trabalho, pois os pais também podem aprender muito e se transformar com a experiência do filho. O contato com a escola se faz periodicamente, com o mesmo objetivo de troca.

No próximo capítulo apresentarei o caso de dois adolescentes, abordados no âmbito da psicopedagogia clínica, tal como apreendo certos referenciais advindos dos estudos de Sara Paín, entre outros. A intenção é fazer um relato detalhado da evolução desses casos, procurando articular os fundamentos da psicopedagogia clínica ao contexto da práxis do atendimento e, ao mesmo tempo, destacar alguns pontos para delinear um problema de aprendizagem específico da adolescência, que consiste no que alguns teóricos chamam de recusa escolar. Alguns aspectos que não foram contemplados neste capítulo serão em seguida abordados de forma mais integrada ao contexto clínico. Vale marcar que esses casos lançam novas questões sobre a clínica da psicopedagogia com adolescentes, pois a problemática dos jovens em questão transcende os problemas de aprendizagem tal como formula Sara Paín. 


\section{Estudos de casos}

Vamos dar agora início a dois relatos de casos clínicos examinados no âmbito da psicopedagogia clínica. Esses casos, apesar de tratarem de situações particulares e com toda a sua singularidade, parecem ter uma relação com um fenômeno contemporâneo: a recorrência das chamadas patologias do agir e das condutas de recusa escolar nos adolescentes.

Nesse sentido, esses relatos se inserem na modalidade de investigação científica de estudos de caso, na acepção de Robert K. Yin (2001), pois partem de um contexto particular, mas seu foco se dirige para um fenômeno contemporâneo.

Essa pesquisa se justifica na medida em que a literatura atual pouco se referencia aos problemas de aprendizagem na adolescência. No campo da psicopedagogia, as pesquisas têm se dirigido principalmente aos estudos sobre a infância, e quando investigam o adolescente, referem-se ao contexto escolar, e não ao atendimento psicopedagógico desses jovens. Inversamente, quando se trata da clínica do adolescente, a literatura psicanalítica parece bastante rica, mas não costuma abordar problemas de aprendizagem.

No intuito de ir além desses casos, de possibilitar um diálogo com outros pesquisadores e mesmo de contribuir para o enriquecimento do campo do conhecimento sobre a adolescência, assim como da escolarização dos jovens, é que esta pesquisa qualitativa ganha o seu sentido.

Acredito que esta tentativa se enquadra na definição de estudo de caso de Robert Yin, citado por Alda Judith Alves-Mazzotti:

(...) uma pesquisa empírica que investiga um fenômeno contemporâneo em seu contexto natural, em situações em que as fronteiras entre o contexto e o fenômeno não são claramente evidentes, utilizando múltiplas fontes de evidência. (2006, p. 643)

Procurei seguir os procedimentos metodológicos indicados por Yin (2001), a começar pelo esforço intenso de construir uma narrativa consistente, em que estejam presentes todas as evidências relevantes. A intenção é favorecer a interlocução com outros casos e pesquisas em outros âmbitos teóricos e científicos, de forma a possibilitar uma compreensão abrangente sobre a recusa escolar entre os adolescentes.

O objetivo é procurar elucidar certos aspectos do contexto social mais amplo, mais especificamente, determinados elementos concernentes às relações intergeracionais, tais como 
se desenvolvem na configuração específica das classes médias urbanas brasileiras na atualidade.

Para esclarecer tais aspectos, vou recorrer a referências dessas correntes da psicanálise que aceitam a inclusão nas suas análises do problema social, no sentido de confrontar esses casos particulares com tendências sociais mais amplas.

O diálogo da psicanálise com outros campos, inclusive o social, não é algo novo. Aliás, foi amplamente utilizada pelo próprio Freud. Seguindo essa tradição, Fabio Herrmann (2005) afirma que a psicanálise consiste na ciência geral da psique, alicerçada no método interpretativo. Ora, a psique se manifesta tanto em dimensões individuais, como também na dimensão coletiva. Renato Mezan acrescenta (2002, p. 318): como o indivíduo é um ser social, é certo que ele seja constituído pelas vicissitudes de seu entorno, daí a validade de a psicanálise adentrar no campo dos fenômenos sociais e culturais. A essa incursão no campo que não se restringe exclusivamente à clínica clássica, do paciente isolado com seu analista, Freud denomina “psicanálise aplicada”.

De acordo com Miriam Debieux Rosa (2004), e mesmo um olhar superficial à obra de Freud confirma, ele não limitou a psicanálise ao âmbito da clínica, publicou obras que investigavam as determinações do inconsciente em diversas manifestações humanas, sociais e culturais. O termo psicanálise aplicada inclusive constava como subtítulo da revista Imago, onde publicou Totem e Tabu (1913) e Moisés de Michelangelo (1914).

Atento às influências do ambiente na constituição do sujeito, Freud utilizou a psicanálise como instrumento de leitura para compreender os significados latentes na organização social. Inaugurou essa tarefa com Totem e Tabu. Dentre seus trabalhos mais instigantes, figura O Mal Estar na Civilização (1929). Nesta obra, analisou a relação conflitante do sujeito com a sociedade e o papel estruturador da cultura em face das exigências pulsionais. Por meio da sublimação, a cultura possibilita a repressão desses impulsos, mas também oferece meios de transformá-los em produtos valorizados socialmente. Em suma, há o lado repressivo da sociedade que Freud enfatizou, no entanto, como ele próprio reconheceu, há na superação do Édipo um aspecto libertador, de o sujeito não ficar refém das exigências instintivas e das neuroses familiares e poder escolher formas culturais que possibilitam sua subjetivação.

Mas se quisermos ir um pouco mais além das colocações de Freud, imerso ainda na falsa dualidade indivíduo/sociedade, veremos que esse papel estruturante da cultura vai além 
da sublimação. Se pensarmos na figura materna, a forma da relação da mãe com o bebê, a função do pai, e o próprio Édipo, são dados da cultura. Nesse sentido, a cultura constitui o sujeito. $^{25}$

No entanto, depois de Freud, o campo da psicanálise ampliada passou a ser problematizado por muitos analistas. Como comenta Octavio Souza (1991), Lacan, numa tentativa de esclarecer essa questão, propôs uma distinção entre “psicanálise em intensão” e “psicanálise em extensão”. Na primeira, ele se refere ao psicanalista e seu processo analítico, de forma que a análise pessoal lhe propicie uma mudança subjetiva. Na segunda, trata-se de ultrapassar o domínio da psicanálise clínica, para além da esfera individual. Octavio Souza esclarece - a extensão dos conceitos psicanalíticos não se confunde com análise selvagem dos mesmos para a compreensão dos fenômenos culturais e sociais. Até mesmo a análise do campo social deve ser acompanhada de uma perspectiva de mudança subjetiva, tal como a psicanálise em “intensão”.

Para Herrmann (2005), a psicanálise extensa, ou psicanálise extra-muros, como denomina Laplanche (1992) consiste não só em estender a psicanálise para outros campos, como ir ao âmago do método analítico: possibilitar a emergência de significados possíveis, mas não presentes à consciência, em qualquer domínio da vida social e cultural. Quando isso acontece, o efeito se dá tanto na abertura para o conhecimento, como também na abertura para uma mudança subjetiva.

Nesse sentido, para o autor, “Como a atenção analítica é sempre clínica, a psicanálise da cultura e da sociedade, a correlação de mão dupla com a literatura e as artes, a própria integração com o reino das ciências, tudo isto é clínica extensa” (HERRMANN, 2005, p. 24).

Dois problemas aqui se colocam. O primeiro é examinar a legitimidade da psicanálise extensiva como a entendeu Freud, à análise de fenômenos sociais como a arte, a guerra, a civilização, a sociedade, etc. O outro é admitir o uso do referencial psicanalítico em

\footnotetext{
${ }^{25}$ Essa questão é também sociológica - Dubet e Martuccelli (1996) remetem à pergunta formulada por Hobbes sobre a natureza da ordem social. A resposta da sociologia clássica, segundo os autores, é que a ordem é produzida pelo ajustamento das ações individuais advindas de uma socialização comum dos sujeitos: a ordem social não resulta nem da natureza, nem de um contrato voluntário, mas de sua interiorização mesma pelos indivíduos. Assim, indivíduo e sociedade são duas faces da mesma realidade, a ação é comum aos indivíduos e à sociedade. As dimensões essenciais da ação se encontram ao mesmo tempo na subjetividade do indivíduo e na objetividade da cultura. A idéia de entrada na cultura é pensada como causa e efeito, como explicação a partir do social do processo de formação dos indivíduos e como explicação a partir da formação dos indivíduos da existência do social. A noção de habitus, formulada por Bourdieu, pode ser vista como uma elaboração teórica sofisticada dessa concepção. Essa noção visa a cruzar, como no jogo de reflexos de espelhos face a face, a objetividade da sociedade e subjetividade dos sujeitos. Abordaremos mais esse tema no capítulo referente à família.
} 
outras esferas que não a clínica ortodoxa, como é o caso da psicopedagogia clínica, de inspiração psicanalítica. Sendo assim, podemos considerar que a psicopedagogia clínica, tal como propõe Sara Paín (1985), se situa no campo da clínica extensa, pois seu fim consiste justamente em estabelecer uma mediação do sujeito com os bens culturais específicos e possibilitar ao jovem uma mudança subjetiva em relação ao saber. Em geral, saber relacionado aos saberes escolares.

Enfim, a tentativa é procurar um sentido mais amplo para certos sintomas que têm se manifestado no âmbito da psicopedagogia clínica. É certo que a confrontação de um elemento advindo do contexto da subjetividade com o contexto social pode correr o risco de reduzir um ao outro, fazer do sujeito um exemplo do caso social, ou, ao contrário, encarar o social como a somatória de casos particulares. Tal não é absolutamente nossa percepção - o recurso à análise psicanalítica da sociedade contemporânea, que permite elucidar certos aspectos dos casos examinados, não pode perder de vista a singularidade irredutível dos sujeitos que foram objeto dessa intervenção psicopedagógica.

A questão da psicanálise extensa no âmbito social nos remete à discussão de Theodor Adorno, desenvolvida em De la relación entre Sociologia y Psicologia (1991). Para o autor, haveria uma tensão entre o campo da subjetividade e o campo social; dizendo de outra forma, entre o particular e a totalidade social. ${ }^{26}$

Adorno (1991, p. 135) estabelece um diálogo entre essas esferas para compreender uma questão muito cara aos filósofos da teoria crítica - por que os trabalhadores dos países altamente industrializados se submetem às políticas de ameaça e agem favoravelmente ao sistema que os oprime? Afirmar que isso advém da indústria cultural ou da propaganda, manipulada pelos dirigentes, não parece ser suficiente para responder a tal questão. O filósofo acredita ser necessário complementar a Teoria da Sociedade com a Psicologia, mais especificamente com a Psicologia Social orientada psicanaliticamente. Uma forma de justificar a conduta dos trabalhadores seria recorrer ao controverso conceito de Freud de pulsão de morte. Entretanto, trata-se de uma questão mais complexa, pois as condições objetivas não foram criadas e nem se reproduzem apenas fazendo intervir na análise o conceito de pulsão de morte. Além de outros problemas que tal recurso acarretaria, seria fazer valer para o social, sem mediações, um conceito retirado da esfera do psiquismo individual.

\footnotetext{
${ }^{26}$ Vale ressaltar que Adorno é contrário à psicanálise aplicada, quando esta é utilizada como instrumento de análise do social. Segundo Conrado Ramos (1999), Adorno se utiliza da psicanálise para investigar, por meio do particular, a mediação da totalidade e com isso desenvolver a teoria da sociedade.
} 
Para Adorno, as leis sociais não podem ser inferidas a partir de dados psicológicos e, de outro lado, o indivíduo não corresponde a um interior autônomo em relação ao meio exterior. Para ele, a sociologia e a psicologia guardam diferenças que devem ser respeitadas. No entanto, como comenta Conrado Ramos (1991), a psicologia adquire um potencial crítico quando leva em consideração o indivíduo confrontado com a totalidade social. O mesmo ocorre com a sociologia, quando esta discute a sociedade e leva em consideração as determinações do particular.

De acordo com Adorno, qualquer tentativa de unificação entre a psicologia e a sociologia acaba por negar a cisão que existe entre ambas, entretanto, querer separá-las implica desconhecer a relação entre elas. Diz Adorno:

La separación entre entre sociedad y psiche es falsa conciencia; eterniza em forma de categorias la escisión entre el sujeto viviente y la objetividad que impera sobre los sujetos y que, no obstante, son ellos quienes producem. Pero no se puede quitar el terreno a esa falsa conciência por decreto metodológico. Los seres humanos no son capaces de reconocer a si mismos em la sociedad, ni ésta em ellos, porque están enajenados entre si y respecto al conjunto. (1991, p. 139)

A tentativa de estabelecer um diálogo entre o particular e a totalidade social implica o reconhecimento da tensão entre um e outro. A via mais produtiva seria por meio do confronto, como se pudéssemos atritar o particular com a totalidade, até algo de significativo aflorar.

Guardando as diferenças entre as duas esferas, o autor volta à questão inicial e acaba por verificar que a conduta do trabalhador de abandonar-se nas mãos dos dirigentes diz respeito a um aspecto da particularidade mediado pelo social. Nas palavras de Adorno (1991, p. 142): “Más esencial resulta, como motivo subjetivo de la racionalidad objetiva, la angustia. Uma angustia mediada”. Tal comportamento advém da angústia de ser excluído do campo social, de virar um lúmpen. O sujeito internaliza uma demanda da totalidade e ela se torna uma “segunda natureza” em função da angústia social. Logo, a submissão do trabalhador ao sistema econômico tem como recompensa a inclusão social. ${ }^{27}$

Pois bem, podemos depreender que o que pode ser compreendido pela sociologia como uma conduta racional de integração do sujeito ao sistema econômico, revelando sua adaptação à realidade social, pode ser interpretada pela psicologia como um comportamento irracional, posto que é motivado pelo temor do sofrimento psíquico. Ramos (1999) alerta - o

\footnotetext{
${ }^{27}$ É verdade que isso vale para os países altamente industrializados, pois nos países em desenvolvimento nem a submissão ao sistema implica a inclusão social, tendo em vista os baixos salários.
} 
que não se pode passar despercebido tanto por uma, como pela outra - que a angústia do risco da exclusão social é, em sua origem, efeito da (boa) integração social do indivíduo. O que pode ser socialmente visto com uma conduta racional, no âmbito da subjetividade pode ser considerada irracional.

Nesse sentido, a confrontação entre ambas as esferas pode ser fecunda, no sentido de explicitar alguns sentidos que a totalidade social não consegue revelar por si só. Passando da análise de Adorno para nosso caso particular, é por tal motivo que, guardadas as proporções, acreditamos que o confronto de alguns relatos de caso de recusa escolar com o contexto social mais amplo pode favorecer a emergência de certos significados latentes sobre o funcionamento social.

Esta pesquisa se estrutura a partir de dois relatos de caso; trata-se, pois, de uma pesquisa marcadamente qualitativa, em que vamos procurar compensar o número limitado de casos pelo aprofundamento daquilo que é visto pela literatura psicanalítica como sintoma de recusa escolar. A intenção é fazer um mergulho na particularidade de cada caso e buscar neles tanto sua singularidade, quanto o que isso permite revelar em confronto com adolescentes na mesma situação.

Dessa forma, o estudo de caso assume um caráter heurístico, como forma de examinar, aprofundar, perceber contradições com aquilo que é visto como sintoma social.

O objetivo é contemplar a subjetividade de certos adolescentes e confrontá-las com a generalidade ao examinar o contexto sociocultural e, mais especificamente, o lugar dos pais no sentido de oferecer um suporte para que os jovens realizem a passagem para o mundo dos adultos.

Renato Mezan (2002, p. 434), quando discorre sobre a pesquisa em psicanálise, afirma: “A singularidade está presente, no plano empírico, por meio do material selecionado; os elementos comuns vão sendo destacados desse material, a fim de constituir a questão a ser estudada”. No nosso caso, a questão versa sobre a recusa escolar como sintoma da negação da diferença geracional.

Os estudos de casos são provenientes da minha experiência na clínica de psicopedagia. São adolescentes que apresentavam mau rendimento escolar e, em razão disso, os pais entraram em contato comigo para a realização de um diagnóstico psicopedagógico, com o objetivo de verificar se o filho apresenta ou não um problema de aprendizagem. 
Trata-se de famílias de nível socioeconômico médio e os filhos são freqüentadores de escolas particulares. Apesar da formação dos pais e de todo investimento familiar, esses jovens manifestam problemas de aprendizagem na escola.

Escolhi esses casos, primeiramente, porque eles trazem algo novo em relação aos problemas de aprendizagem escolar; como se verá, não se trata de um problema de aprendizagem como sintoma, tal como nos deparamos usualmente na clínica da psicopedagogia. A problemática que esses jovens trazem não está centrada numa dificuldade cognitiva específica, mas na falta de autonomia no processo de aprendizagem escolar e na dificuldade de sistematização do conhecimento aí adquirido. No entanto, quando nos aproximamos de tal problemática, observamos que a verdadeira questão desses jovens está colocada na ambivalência frente à integração na ordem escolar.

O outro motivo, aparentemente paradoxal, que me levou a propor a discussão de tais casos é o fato de que eles parecem não terem sido bem-sucedidos, pois foram interrompidos sem terem sido concluídos, mostrando, talvez, as minhas próprias limitações e/ou talvez as limitações da própria prática psicopedagógica, que esbarra, como acontece na clínica psicanalítica de adolescentes, na problemática atinente à família ou aos pais do jovem.

No entanto, essa perplexidade é que me levou a debruçar-me mais atentamente sobre esses dois casos, permitindo também discutir os seus desdobramentos teóricos e clínicos colocando questionamentos que me fizeram percorrer a literatura sobre o tema.

Isso remete a Alda Mazzotti (2006, p. 650), que comenta que um caso retrata "uma situação complexa e/ou intrigante, cuja relevância justifique o esforço de compreensão”.

Nesse sentido, a brevidade dos casos permitiu a descrição e narração pormenorizada de cada um deles. O detalhamento da configuração particular que os casos assumem podem conduzir a descobertas sobre a natureza de determinados problemas de aprendizagem.

Ao dialogar com a literatura existente sobre a adolescência, acredito que o estudo desses casos permitirá melhor compreensão, ou mesmo melhor teorização, sobre um conjunto ainda maior de casos e possa contribuir para futuras pesquisas.

$\mathrm{Na}$ verdade, são casos que remetem ao tema da complexidade com que certas configurações familiares repercutem sobre a escolaridade dos jovens, em virtude de ter-se colocado a negação da diferença geracional entre pais e filhos. Nesse sentido, o sintoma da aprendizagem tem a função de denunciar a dificuldade do jovem de fazer a passagem da adolescência, sem referências que lhe permitam estabelecer os laços sociais que a instituição 
escolar e a cultura, numa acepção mais ampla, deveriam propiciar. São jovens que se sentem desprovidos de recursos para constituir uma identidade distinta das insígnias familiares e de conquistar sua autonomia. Em virtude de tal complexidade que essa pesquisa toma seu sentido.

Dando prosseguimento à apresentação dos casos, cabe esclarecer a estrutura dos mesmos. Cada relato de caso seguirá o seguinte percurso: num primeiro momento, descreverei a primeira entrevista com os pais, em que estabeleço suas queixa e pesquiso os dados relativos à primeira esfera: do sujeito e de sua família. A história do sujeito e a história escolar advêm dessa entrevista inicial. ${ }^{28}$ Em seguida, relatarei o diagnóstico psicopedagógico, que se detém na segunda esfera, da relação do sujeito com o conhecimento. Depois discutirei a conclusão diagnóstica e a entrevista devolutiva aos pais, que se aprofunda sobre as três esferas, conjuntamente. Por fim, farei um relato do atendimento psicopedagógico. Essa separação em esferas e em momentos do diagnóstico ou atendimento não é estanque. Trata-se de uma separação meramente didática, pois todos os dados podem responder a questões de diferentes esferas e momentos. Essa é apenas uma tentativa de delimitar o campo em que se estruturam a teoria e a intervenção psicopedagógica.

\subsection{Fábio - A recusa a entrar no jogo escolar}

\subsubsection{Primeira entrevista com os pais}

Os pais de Fábio me procuraram por indicação do médico da família, cujo filho adolescente eu havia atendido anos antes.

Fábio é um adolescente de 14 anos, de família de classe média. Estava na oitava série $^{29}$ e no momento estava sem estudar, pois havia sido convidado a se retirar da escola onde estudava por problemas de indisciplina. Fato que ocorreu nos últimos três estabelecimentos em que estudou. Há dois anos está apresentando problemas disciplinares e nesses anos estudara em uma escola que se configurava como uma "rede de ensino", oferecendo desde a Educação Infantil até cursos universitários. Tal rede se estendia por todo o estado.

\footnotetext{
${ }^{28}$ Por vezes, solicito uma segunda entrevista, para conversar sobre determinados temas que não puderam ser aprofundados em um só encontro.

${ }^{29}$ A terminologia utilizada nestes casos diz respeito ao Ensino Fundamental de 8 anos, que vigorou até o ano de 2006.
} 
Fábio já havia feito psicoterapia duas vezes, mas nunca de abordagem psicanalítica. Havia decidido parar nas duas ocasiões. De acordo com os pais, em nenhum dos dois tratamentos foi realizado um diagnóstico, no sentido de orientar o trabalho psicoterapêutico.

As questões que os pais trazem referem-se mais ao comportamento agitado e indisciplinado do filho, do que propriamente uma preocupação escolar. O relacionamento com o jovem está tenso, pois ele está manifestando bastante oposição frente aos pais.

Quanto à sociabilidade, de acordo com os pais, Fábio não tem amigos. Não vai à casa de outros jovens e nem é visitado por colegas, porém vai a danceterias e tem conhecidos no mundo clubber. Está bastante mobilizado para ser $D^{\prime} J$.

Os pais não conseguem discriminar se as dificuldades de o jovem se manter na escola derivam de uma dificuldade de aprendizagem ou de uma questão emocional. Falam que “ele não sabe nada” do conteúdo escolar, mas que apresenta um grande potencial criativo, sobretudo em música e em informática. Porém, nunca se dedica a fundo a seus interesses. Fica mobilizado por um objeto de interesse e só se dedica a ele, para logo abandoná-lo. Foi assim com música, balões e agora com informática. Está dominando tanto a área de informática, segundo os pais, que mudou as configurações no único computador da casa, pôs uma senha que só ele tem acesso e a família ficou impedida de utilizá-lo. Apesar de ficar submetido ao desejo do filho, o pai parece se vangloriar da atitude do filho.

De acordo com os pais, ele tem uma grande energia, mas não a dirige para a aprendizagem formal. A escola representa algo à parte, não ocupa um lugar significativo em sua vida. Para ele, estudar não implica nem compromissos, nem submissão a normas. Na sua concepção, a escola é um lugar onde se faz o que quiser. Não leva o material escolar, perde as apostilas e nunca comunica esse fato aos pais. Jamais foi reprovado, mas sempre tira notas baixas; faz recuperações e acaba sendo aprovado no final.

Noto que os pais parecem idealizar o potencial do filho e acreditam que o problema está nas escolas. O pai suspeita que o filho seja superdotado e teme que ele esteja em uma escola inadequada, desperdiçando suas potencialidades. De acordo com tal lógica, ele necessita de uma escola “diferenciada e dinâmica”. Porém, tal idealização não se sustenta e dá lugar a outra suspeita - a de que o filho tenha transtorno de hiperatividade, que parece ser igualmente fantasiosa.

Desde o início, observo que os pais não conseguem discriminar se o problema advinha da escola, por ser inadequada para o filho, ou se advinha do comportamento agitado e 
perturbador do filho. Parece que, nesse raciocínio, não há, por parte dos pais, um espaço para o questionamento sobre sua participação em tal problemática, mais especificamente, o seu lugar como adultos e educadores, no sentido de ajudá-lo a tolerar as situações de frustração, curvar-se às normas sociais e inseri-lo no mundo da cultura.

Pergunto se Fábio os reconhece como figuras de autoridade e o casal conta que ele não respeita a mãe. Em relação ao pai, está começando a enfrentá-lo, com agressões verbais. O pai relata que perdeu o controle recentemente e o atacou fisicamente. Fábio se defendeu, mas não revidou. Atualmente, segundo os pais, há uma divergência no casal quanto à questão dos limites e o filho percebe isso. A mãe mostra-se mais permissiva e o pai acredita que é necessário serem mais rígidos com o filho.

Esclareço aos pais qual é a minha área de trabalho e proponho realizar um diagnóstico psicopedagógico. O objetivo seria tentar elucidar os aspectos ligados à aprendizagem escolar de Fábio, sobretudo quanto à dimensão normativa desta, pois parece que o jovem se recusa a se submeter a regras. Paín (1985) identifica tal forma de se relacionar com a aprendizagem como modalidade hiperassimilatória ${ }^{30}$ em relação ao conhecimento. De acordo com tal funcionamento, o sujeito nega curvar-se aos objetos de aprendizagem, querendo sempre submetê-los às suas necessidades e desejos.

Acrescento que muitas vezes se faz necessária uma complementação diagnóstica com profissionais de outras áreas: psicologia, psiquiatria, neurologia, e, caso isso fosse necessário, seria solicitado na entrevista devolutiva aos pais, no final do diagnóstico. Os pais aceitam a minha proposta.

O primeiro passo no diagnóstico psicopedagógico é reconstruir a história da criança ou adolescente e observar o lugar do sujeito para os pais, verificar o que representa o problema dos filhos na dinâmica familiar, entre outros dados. No caso de Fábio, algumas questões chamam a atenção quanto à submissão a normas.

\subsubsection{História do adolescente}

Marquei uma segunda entrevista com os pais para levantarmos dados da história de Fábio. Os pais relatam que estão na faixa dos cinqüenta anos, são comerciantes e mostram um

\footnotetext{
${ }^{30}$ Trata-se de uma tendência, na relação com o objeto de conhecimento, a predominar o mecanismo da assimilação, tal como propõe Piaget. A assimilação implica o movimento do sujeito de transformar a realidade para integrá-la às suas possibilidades de ação.
} 
perfil mais “alternativo”. Não se identificam com valores ditos burgueses, de consumo, de adequação ao status quo. A família havia morado no interior de São Paulo por cinco anos, na cidade da família do pai, logo após o nascimento de Fábio. A mudança para o interior, segundo os pais, foi no sentido de ter uma vida mais saudável, longe dos centros urbanos. Porém, tal projeto fracassou, pois naquela cidade era difícil alcançar a estabilidade financeira almejada pela família.

Os pais nunca fizeram um planejamento familiar e tiveram três filhos, um de 23 anos, que estuda no Sul, outro de 22, que é estudante e mora com os pais, e Fábio, de 14, que é o “temporão”.

O discurso dos pais é permeado por críticas quanto à ordem capitalista, embora o pai tenha trabalhado em uma empresa financeira. Também são críticos à educação repressiva, acreditam que tudo deve acontecer naturalmente, sem uma intervenção ou limite por parte do adulto. Assim, Fábio foi amamentado até os 3 anos de idade e sempre foi criado com muita liberdade.

A gravidez de Fábio teve um significado especial para a mãe, segundo esta, pois, dois meses antes, havia perdido sua mãe, que ficou doente e faleceu. Depois da experiência de uma grande perda, engravidou, teve o bebê e criou um intenso apego por ele.

A educação de Fábio é marcada pelo apego da mãe e pelos ideais liberais do casal. Segundo tais ideais, a relação entre pais e filhos não deve ter qualquer assimetria e todos os limites são vistos como repressivos, pois impedem a livre expressão da criança.

Examinando alguns dados do desenvolvimento de Fábio, observo que a mãe não lhe deu limites, e, por acréscimo, prolongou a relação de dependência. Como já foi dito, foi amamentado até os três anos - a mãe afirmou que "foi duro ele soltar as tetas” (sic). Com certo regozijo, disse: “até hoje ele olha para as minhas tetas” (sic), como se o seio materno ainda representasse algo significativo para o filho.

Fábio apresentou enurese noturna até os seis anos. Quando perguntada sobre sua ação no sentido de ajudar o filho na aquisição do controle dos esfíncteres, a mãe diz que não fez nada de “muito drástico”. Tal postura revela a crença subjacente de que as aquisições no desenvolvimento da criança aconteçam naturalmente, como se qualquer intervenção dos adultos fosse repressiva, antinatural.

A família morava no interior e Fábio era muito livre e independente. Andava nu pela casa. Quando tinha um ano, sua mãe começou a trabalhar e ele passou a ficar na casa dos 
avós, que o adoravam. Aos dois anos, começou a freqüentar a escola, mas não gostava. Queria ficar com os avós.

Quando Fábio tinha cinco anos e meio, seu pai mudou-se para São Paulo, para montar uma empresa e viabilizar a mudança definitiva da família para essa cidade. Ficou morando fora por seis meses. Nesse período, Fábio teve nefrite e saiu da escola, pois, segundo recomendação médica, necessitava de repouso absoluto. Na época da ausência do pai, Fábio ficou dormindo na cama com a mãe.

O tratamento de nefrite durou um mês. Fábio teve uma boa recuperação e logo a família mudou para São Paulo. Apesar de estar curado, não retornou à escola naquele ano, permanecendo em casa.

A família instalou-se num apartamento e, segundo os pais, Fábio queria sair e ficar livre como na cidade do interior, apresentando dificuldade de entender que nem o prédio todo era sua casa e que, na cidade grande, não poderia ter a mesma liberdade que antes.

É possível levantar a hipótese de que Fábio tenha sido fruto de um projeto libertário dos pais, no qual se valoriza uma educação expressiva e uma vida mais simples, sem aderir ao status quo. Qualquer estabelecimento de limites é visto como negativo, prejudicial à autenticidade do sujeito. Fábio cresceu em um mundo de iguais, em que os adultos não estabeleceram a diferença geracional, não marcaram que ele era criança, em um mundo de adultos, com regras que todos devem seguir. Sem limites e sem escola, Fábio foi criando grande resistência a todo tipo de coerção, como o enfant sauvage, de Jean Itard.

O paradoxo é que, apesar do ideário dos pais, segundo o qual não havia espaço para as ambições materiais, Fábio acabou se tornando bastante consumista, sendo muito voltado para o sucesso e a riqueza. Segundo os pais, afirmava que faria qualquer coisa para ser rico. Duvidavam do seu caráter ético. A ausência de leis em toda a educação do filho teve um efeito inesperado em sua formação e passou a ser um motivo de preocupação para os pais.

\subsubsection{História escolar}

Depois de obter os dados sobre a história de Fábio, dirigi a entrevista para a história da sua escolaridade. 
No interior, Fábio estudou em uma escola municipal que não lhe agradava. Freqüentemente fugia da escola e ia para a casa dos avós, que ficava logo à frente.

De volta a São Paulo, depois de ficar quase um ano sem escola, aos seis anos, Fábio entrou em uma escola católica. Permaneceu lá do Pré, da Educação Infantil, até o fim da quinta série do Ensino Fundamental, quando foi convidado a se retirar por problemas disciplinares. Segundo os pais, ele liderava a bagunça e depois não assumia seus atos. Fábio "zoava", mas isso não prejudicava muito o seu aproveitamento pedagógico e nem sua integração escolar, ainda de acordo com os pais. Nessa escola, ele tinha um amigo, com quem brincava e passeava no período extra-escolar.

Quando foram procurar uma nova escola para Fábio, visitaram várias e foi Fábio quem escolheu a escola. Os pais o deixaram optar por uma escola católica bem tradicional da região central de São Paulo, mesmo sabendo que era bem rígida.

Podemos depreender desse fato que esses pais pareciam estar superestimando a possibilidade de Fábio de fazer escolhas e da sua capacidade de decisão. Talvez eles acreditassem que o filho deveria ter liberdade de escolha, porém a liberdade geralmente é uma decorrência da maturidade do indivíduo, o que não era o caso. Se havia alguma pertinência nessa escolha, era o fato de ela revelar o quanto Fábio clamava por normas.

Do ponto de vista social, segundo os pais, aquela instituição parece ter sido interessante, pois era uma escola grande e lá ele ampliou suas relações, integrou-se a uma turma, participou da banda da escola e até começou a namorar. Porém, o jovem casal de adolescentes não se controlava e a forma como se comportava publicamente na escola causava indignação nos adultos. Não pareciam discriminar o espaço público do privado, e também não pareciam querer preservar a intimidade do casal.

Nessa época, os pais o levaram para fazer terapia de abordagem bioenergética e inclusive os próprios pais acabaram iniciando um trabalho terapêutico. Fábio não gostou de tal abordagem e acabou abandonando o tratamento.

Mais uma vez, os pais mostram dificuldade de se discriminarem de Fábio, pois acabaram por iniciar uma terapia com o mesmo profissional, invadindo o espaço terapêutico do filho.

No fim do ano, Fábio foi convidado a se retirar da escola por indisciplina. Em seguida, os pais procuraram a já citada rede de ensino, que é reconhecida por ser bastante 
liberal quanto às normas, tanto do ponto de vista do aproveitamento escolar, como em relação à disciplina.

Fábio iniciou uma nova terapia da qual parecia gostar. De acordo com o pai, conversavam sobre “espiritualidade” e “mediunidade”. Curioso é que os comentários sobre as terapias nunca enfatizavam o processo terapêutico em si, os benefícios do tratamento, mas, sim, características da abordagem terapêutica. Parece que os pais se centram em algo externo, que enfoca mais a forma do que o conteúdo do atendimento. Vale notar que as abordagens escolhidas tendem a confundir misticismo e religiosidade com a questão emocional.

O jovem estudou nessa escola por um ano e meio, mas não parecia interessado em integrar-se àquela instituição, no sentido que apontam François Dubet e Danilo Martuccelli (1996). Não tencionava aderir às formas legítimas de autoridade daquela instituição, ocupar um lugar e um papel que lhe eram preexistentes e a partir daí colocar sua adesão ou crítica. Fábio nunca fazia as lições, desafiava os professores e não parava na sala de aula. Mesmo assim, passou de ano, pois tinha muitas oportunidades para recuperar as notas baixas. A falta de referências foi fazendo com que Fábio ficasse cada vez mais ousado em relação aos limites.

O jovem abandonou a terapia. A escola sugeriu aos pais que o filho fizesse um psicodiagnóstico, oferecendo inclusive o serviço da faculdade de Psicologia daquela instituição de ensino; porém não conseguiram uma vaga para Fábio. A atitude do adolescente foi tornando sua presença na escola insustentável. Os pais relatam que ele xingou um professor e apresentou atitudes desrespeitosas para com os funcionários. Acabou por molestar uma aluna só para provocar o irmão dela, que estava na frente, segundo os pais. Foi, mais uma vez, convidado a se retirar.

Vale notar que a escola também não tinha clareza quanto aos limites. Era permissiva com coisas que não deveria ser, como deixar o aluno ficar sem material escolar, não entregar tarefas, aprová-lo, quando o jovem não demonstrou qualquer comprometimento durante o ano letivo. Porém, a escola não tolerava comportamentos que fazem parte de uma atitude mais exploratória do ponto de vista da sexualidade e que são aceitas entre os jovens em determinadas situações, como passar a mão no corpo do outro.

Quando os pais me procuraram, Fábio estava havia uma semana sem escola e eles cogitavam a hipótese de o tirarem do ensino regular, acreditando que uma formação mais técnica fosse mais produtiva para ele. Fábio estava trabalhando com os pais na empresa 
familiar, com a tarefa de cuidar do setor de informática, mas seu comportamento naquele ambiente estava bem inadequado, pois bulia onde não devia e tumultuava a atmosfera de trabalho.

Fábio parecia estar solto, clamando por uma contenção dos adultos e por um grupo de pares, em que pudesse trocar e interagir. Estava claro que ficar no mesmo ambiente que os pais o dia inteiro, com quem estava mantendo conflitos, poderia agravar a situação.

As atuações de Fábio pareciam estar relacionadas à labilidade de atitudes e escolhas dos pais em relação à educação do filho. Ora acreditavam que uma escola rígida seria boa para o filho, ora achavam que a escola deveria ser flexível. Isso também se colocava em relação ao tipo de ensino - regular ou técnico. O mesmo é possível observar quanto à terapia, primeiro escolheram uma abordagem bioenergética e depois uma terapia de enfoque espiritual. Não havia uma clareza do que deveriam propiciar ao filho.

Esclareci que seria importante insistir no término do Ensino Fundamental e, nesse ínterim, pesquisar alternativas de ensino mais adequadas ao filho. Além do mais, estávamos no mês de maio e Fábio não poderia ficar inativo e sem um grupo social de referência. Usei o argumento de que freqüentar a escola constitui um direito, previsto por lei, para crianças e adolescentes e corresponde a um dever dos pais. Sugeri que procurassem uma escola menor, para que pudesse finalizar o Ensino Fundamental e onde o corpo técnico tivesse condições de acompanhar o aluno com mais atenção.

\subsubsection{Diagnóstico Psicopedagógico}

Desde a primeira sessão do diagnóstico, Fábio é bastante receptivo e mostra-se um adolescente inteligente, com senso de humor, ambicioso, curioso e criativo. Em nosso primeiro encontro, conto no que consiste a psicopedagogia e relato alguns tipos de problemas das crianças e adolescentes com quem trabalho e pergunto se algum daqueles problemas lhe ocorria. Ele responde: quase todos. No entanto, quando lhe pergunto sobre seu desempenho na escola, o que achava das disciplinas, se tinha alguma dificuldade específica, ele diz que geralmente achava tudo fácil.

Desde o início das atividades, Fábio mostra-se desprovido de um método de trabalho. Apesar de bem disposto, apresenta dificuldades em diversas tarefas, sobretudo nas situaçõesproblema. Tem uma forma assistemática de trabalho. Não estabelece uma variável para 
controlar a situação, pelo contrário, sempre inclui novas variáveis, e isso impede a averiguação do ponto que deve ser modificado em sua estratégia.

Muitas vezes, as soluções que propõe para algumas situações acabam sendo ingênuas e infantis. Na proposta do quadrado mágico ${ }^{31}$, (que ele mesmo sugeriu), inicia a resolução com uma hipótese espacial, sem considerar o resultado da soma dos números nas linhas e colunas, que deveria ser 20. Assim, põe numa linha 2-2-2-2, que é inferior a 20, e depois troca por 8-8-8-8, que é superior a 20. Utiliza a percepção como elemento de relação, em vez de realizar uma operação mental ${ }^{32}$, que consiste na possibilidade de estabelecer relações lógicas sobre os objetos de conhecimento — relações de classe, série e quantidade.

Outras vezes, cria estratégias complexas demais, que poderiam ser mais simples.

Falta-lhe um controle da produção cognitiva, segundo Marta Khol de Oliveira (2004). Não há um acompanhamento e avaliação do próprio sujeito do desenvolvimento da tarefa que realiza. Quando lhe dou uma referência, isso acaba fazendo com que ele abandone as estratégias mirabolantes e articule melhor seus procedimentos. Parece que tal intervenção o faz entrar em contato com a realidade, deixando de lado sua onipotência.

Tudo o que diz respeito ao estabelecimento de coordenadas, a um sistema para solucionar os problemas, é evitado. Fábio procura estabelecer soluções criativas, jamais se submetendo à estrutura do objeto de conhecimento.

Nesse sentido, pude confirmar a hipótese inicial de uma modalidade hiperassimilatória de aprendizagem. Ele clama por uma mediação, necessitando de referências, modelos, enfim, uma direção para desenvolver sua produção.

Realizei com ele as provas piagetianas de pensamento formal, propostas por Longeot e sistematizadas por Lino de Macedo (1983).

Uma das provas realizadas é a de permutação, que avalia se o sujeito compreende o que é tal operação. Permutar corresponde a uma maneira determinada de dispor um conjunto de objetos, de forma que nenhuma ordem seja repetida. A prova solicita que o sujeito faça a predição de quantos modos é possível permutar certo número de fichas coloridas.

\footnotetext{
${ }^{31}$ Atividade de raciocínio lógico semelhante ao passatempo Sudoku, porém, neste, ele tem de preencher uma matriz de 4 X 4, utilizando os números 2,4,6 e 8, sendo que em todas as linhas e colunas a soma deve ser 20 . Portanto, este jogo é bem mais simples do que o Sudoku, que tem uma matriz de 9 X 9.

${ }^{32}$ Segundo Piaget (1986), trata-se de uma ação interiorizada e agrupada em um sistema coerente e reversível.
} 
Fábio prediz e acerta na questão inicial, de 2 fichas de cores diferentes. Elas podem resultar em 2 modos (azul-vermelho e vermelho-azul). No caso de 3 cores, ele também prediz e acerta (dariam 6 modos). Porém, quando se trata de 4 cores, ele usa o raciocínio da multiplicação simples, quando o correto seria uma operação de potência. Raciocina da seguinte forma:

Se são 2 fichas coloridas, então 2 X $2=4(\mathrm{OK})$

Se são 3 fichas coloridas, então 2 X 3 = 6 (OK)

Se são 4 fichas coloridas, então 2 X 4 = 8 ( Não, pois o correto seria 24). Isto é, tal raciocínio não se aplica à situação de 4 fichas. Peço que execute os diferentes modos de permutação e ele começa:

Vermelho-azul-rosa-laranja

Vermelho-azul-laranja-rosa

Azul-rosa-laranja-vermelho...

Aparentemente, seu sistema de resolução parecia ser: fixar a primeira cor tantas vezes quanto for possível e permutar as outras cores, para, em seguida, fazer o mesmo com outra cor. Porém, ele começou com esse método, mas o abandonou antes de esgotá-lo com a cor vermelha. Nas permutações seguintes, teve de recorrer ao ensaio e erro. Depois de muitas permutas aleatórias, fiz um comentário sobre a cor da primeira posição, e ele percebeu que teria de repetir a vermelha na primeira posição 6 vezes e assim, sucessivamente.

Pude constatar que Fábio apresenta dificuldade de lidar com proposições formais. O pensamento ainda está atrelado à experiência, sem poder lidar de maneira mais formal com as tarefas cognitivas.

Notei também que, quando tem de manter um esforço continuado para resolver uma tarefa, acaba desistindo. Tal atitude se repetiu diversas vezes durante o diagnóstico e isso é freqüente em seu histórico, como no caso do aprendizado de música.

Fábio parece não ter se convertido ao ofício de aluno. Não entrou na lógica do trabalho escolar, que é construída à base de regularidades, muito esforço e adiamento das gratificações, de acordo com Philippe Perrenoud (1995, p. 16). O ofício de aluno depende fortemente de um terceiro: da mediação de um adulto. Importante marcar que, num contexto de mediação, é necessário que o adulto esteja numa posição de autoridade, numa relação de assimetria, pois esse adulto tem mais experiência e saber. Esse tipo de relação é bastante 
conflitante para Fábio, pois em casa nunca era marcada a diferença geracional entre pais e filho.

Fábio estabelece uma relação binária em relação ao conhecimento, na acepção de Bernard Charlot (2000): ou sabe tudo, ou não sabe nada, sem fazer uma gradação. Quando acredita que sabe tudo, fica onipotente, pois acredita que sua idéia seja genial. Quando não consegue resolver um desafio “fácil”, em sua opinião, vai para o pólo da impotência.

Quando depara com um desafio em que se sente desprovido de recursos, deprecia as proposições: diz que o enunciado não é claro, o gráfico não é nítido, etc. Trata-se de uma forma de projeção, ele deposita no objeto algo próprio que lhe desagrada - o não saber, suas deficiências, entre outros elementos.

Quando se sente ameaçado, ataca. Parece que foi assim que sempre lidou com os professores e com as situações de desafio no contexto escolar.

No desenho do Par Educativo, Fábio faz uma sala com um aquário do tamanho de uma lousa, cheio de peixes e plantas, e em cima desta está escrito Anima Mundi. Ao lado, há uma professora que aponta para o aquário com uma vareta, e sua figura é bem elaborada e está sorrindo. Na sala há algumas carteiras e há um aluno sentado no chão e parece estar olhando para o aquário. Ao ser perguntado sobre o desenho, Fábio diz que era uma aula de biologia do $1^{\circ}$ ano do Ensino Médio. Diz que o aluno está gostando da aula, está "relaxado". Conta que o aluno propôs à diretoria fazer o aquário e sua proposta foi aceita.

A partir de tal representação da aprendizagem, me parece que Fábio ainda está ligado à escola. Deseja ingressar no Ensino Médio, prosseguir em sua escolaridade (no ensino regular, vale notar). Porém, sua atitude denota uma resistência a integrar-se ao sistema escolar. Em seu desenho, colocou o aluno a certa distância do aquário, mantendo-se à margem, uma vez que não estava sentado na carteira. É ambivalente quanto a "jogar o jogo" escolar (DUBET; MARTUCCELLI, 1996).

Há, também, um pensamento mágico em relação à aprendizagem, como se aprender fosse algo simples, desprovido de esforço e tensões. Na sua acepção, para aprender, basta estar "relaxado".

Por fim, Fábio parece compartilhar a imagem idealizada que os pais fazem a seu respeito. Acredita que suas idéias são muito criativas e passíveis de serem concretizadas, como no caso do aquário. Se ele idealiza a própria imagem, faz o mesmo em relação à escola - esta deve ter equipamentos sofisticados, professores compreensivos - enfim, a escola deve 
ser "especial". Se há uma idealização, de um lado, há, de outro, o pedido por referências e por uma escuta, no sentido de lidar com as escolas "reais", tais como elas se apresentam.

Quanto ao aspecto emocional, Fábio comportou-se bem comigo e sempre respondeu bem às minhas propostas, mostrando-se bastante colaborador. Não apresentou produções e nem discursos bizarros. Além disso, chegava bem mais cedo e controlava-se na sala de espera, sem ficar impaciente. Tampouco transparecia estar sofrendo com sua situação, embora suas atuações na escola e o comportamento reativos em casa certamente significavam um pedido de ajuda.

\subsubsection{Conclusão diagnóstica}

Ao fim do diagnóstico, concluí que a idealização que os pais faziam de Fábio e que ele também tinha de si parecia estar prejudicando a sua inserção nas escolas e o enfrentamento das suas dificuldades. Os pais não conseguiam sustentar os dados de realidade necessários para favorecer a integração escolar e social do filho. Do lado das escolas, estas pareciam não favorecer tal adaptação, pois ora eram rígidas demais, ora eram excessivamente tolerantes. E, pior, alimentavam a onipotência de Fábio, pois este sempre acabava sendo aprovado.

A idealização, segundo Freud (1914), é fortemente marcada pelo narcisismo. Fábio ora parecia ocupar o lugar do ego infantil, objeto de toda perfeição na acepção dos pais, como em “sua majestade o bebê”, ora depositava nos objetos o atributo da perfeição. O importante a marcar é que a idealização impede a sublimação, que consiste na modificação da meta pulsional, na substituição do objeto pulsional para outro que seja valorizado socialmente. Dessa forma, Fábio se nutria da idealização de que era objeto e investia muito pouco no mundo da cultura.

Levei o caso a supervisão (com uma psicopedagoga com formação tanto em psicologia como em psicanálise) e pude confirmar que havia um problema de aprendizagem, pois, do ponto de vista cognitivo, sua estrutura lógica ainda não havia acedido ao pensamento formal, período marcado pelo pensamento hipotético-dedutivo. Isso dificultava a interação com os desafios escolares, que exigiam uma constante formalização. Fábio apresentava uma modalidade hiperassimilatória de aprendizagem, o que o levava a querer submeter indiscriminadamente os objetos de conhecimento aos seus esquemas. De acordo com 
Fernández (1990, p. 110), na hiperassimilação há um "predomínio da subjetivação, desrealização do pensamento, dificuldade para resignar-se” ao objeto.

De fato, a forma de Fábio interagir com os objetos era marcada pela recusa a submeter-se à legalidade própria aos elementos, donde se conclui que os objetos de conhecimento haviam se transformado em objeto de pulsão, como afirma Paín (2000, p. 61): estavam submetidos ao seu desejo.

No que dizia respeito ao aspecto emocional, naquele momento, não havia nenhum sinal de desestruturação psíquica ou de distúrbio de comportamento, porém, se ele continuasse a ser somente punido pelas instituições, sem experimentar qualquer gratificação, isso poderia colocá-lo em risco. Até aquele ponto, as punições tiveram o caráter de premiação para ele, pois não tivera de se submeter à lógica do trabalho escolar. Porém, o que Fábio não parecia haver notado, é que havia perdido amigos e deixara de aprender (ou talvez fosse exatamente o contrário: havia dado pela falta de outras referências, tanto é que estava sendo colaborador num trabalho que visava a reconduzi-lo à escola). Estava excluído e sua adaptação escolar e social corria risco de se tornar turbulenta.

Nesse sentido, não havia um sintoma na aprendizagem, tal como formula Sara Paín (1996), no sentido de uma operação lógica estar a serviço de uma estrutura simbólica, significante, o que havia era uma estrutura lógica prisioneira, uma inteligência que sofria uma diminuição de sua função, no dizer de Parente (2000, p. 66). Fábio parecia não estar interagindo com os objetos, no sentido de ser afetado, transformado pelos objetos, como acontece no processo de adaptação do sujeito ao ambiente, tal como propõe Piaget. Isso porque os mesmos tinham tomado um valor subjetivo; para ele, os objetos culturais não tinham qualquer legitimidade, eles eram, sim, objetos de pulsão.

Havia elementos neste caso que me levaram a acreditar que se tratava de um problema de aprendizagem, apesar de não consistir em um sintoma como Paín propõe, focado em uma operação mental específica. No entanto, a estrutura cognitiva estava aprisionada à estrutura subjetiva e os objetos da cultura haviam perdido seu estatuto para esse jovem. Aos poucos ia se afirmando aos meus olhos a hipótese de que a causa de tal problema se situava na relação dos pais com o filho, no fato de Fábio ficar colocado no lugar do ideal, de ser poupado de todas as experiências que qualquer aluno deve passar e, o mais grave - estava restrito somente às referências familiares. 


\subsubsection{Devolutiva aos pais}

Relatei aos pais as minhas hipóteses diagnósticas, as conclusões a que cheguei, e propus a eles um atendimento psicopedagógico no sentido de abri-lo para experiências com diferentes objetos culturais, com a mediação de um terceiro (o psicopedagogo). O fim seria viabilizar uma relação de verdadeira troca, em que Fábio pudesse, de fato, ser afetado pelos objetos. A intenção seria enriquecer seu repertório, acumular conhecimentos que o levassem a necessitar realizar uma organização mental, de forma a ampliar sua estrutura lógica de pensamento. Ao mesmo tempo, procuraria oferecer situações que o levassem a se submeter à lógica do trabalho escolar.

Procurei marcar que Fábio não perderia sua autenticidade com isso - o fato de se submeter à lei não implica perda, mas sim, enriquecimento do repertório e dos recursos. A proposta seria ajudá-lo a estabelecer uma relação com o conhecimento por meio da qual ele pudesse criar um método para enfrentar os desafios escolares e propiciar uma ampliação do seu universo cultural.

Enfatizei a necessidade da mediação, de dar um suporte para essa passagem ao mundo dos adultos, que lhe parecia tão difícil e desprovida de gratificações. Apontei que a situação era muito delicada e, dependendo das respostas do ambiente, haveria, a meu ver, duas possibilidades: ou esse momento poderia constituir-se num degrau para o desenvolvimento do Fábio, ou as coisas poderiam tornar-se bastante difíceis, pois, sem um projeto, ele poderia perder-se.

Combinamos estabelecer um contato freqüente e avaliar em um curto período o quanto Fábio poderia beneficiar-se desse trabalho, e, se as coisas continuassem como estavam, uma complementação diagnóstica seria solicitada para verificar que outras intervenções seriam necessárias. Ficou combinado um atendimento uma vez por semana, em virtude de questões financeiras.

Durante o período do diagnóstico, os pais o colocaram em uma escola menor, porém bem estruturada e com profissionais experientes com adolescentes. De acordo com os pais, a escola notou em um curto período que Fábio necessitava de grande dirigibilidade em relação à aprendizagem e rigidez quanto às normas.

Também sugeri que os pais conversassem com os profissionais da escola, verificando se haveria a necessidade de aulas particulares, uma vez que ele apresentava uma dupla 
defasagem: defasagem cognitiva, pois não havia construído os instrumentais do pensamento formal, que, segundo Piaget, são necessários para lidar com os diferentes desafios (formular hipóteses, compreender um texto mais complexo), e ainda, parecia apresentar uma defasagem pedagógica, pois não havia se apropriado dos conteúdos escolares da sua série.

Apontei aos pais que Fábio parecia manifestar uma atitude positiva em relação à nova escola, pois vinha ao consultório com o uniforme escolar e havia relatado com interesse a apresentação a que assistira na escola de um profissional da área editorial. O pai foi bem sarcástico em relação a esta, dizendo que eles levaram um profissional só para "vender livros". Marquei que Fábio necessitava naquele momento da sustentação dos adultos na adaptação à nova escola; eles necessitavam legitimar aquela instituição e, portanto, era melhor guardar para si tais impressões.

A atitude ambivalente em relação a tudo o que dizia respeito a uma integração a uma instituição social parecia ter para esses pais o valor de submissão e de coação. Eles não percebiam que a escola, qualquer que seja, sempre tem um projeto de aluno e este se concretiza pelos conteúdos ministrados, mas também pela atitude dos professores, atividades, eventos, etc. Ao integrar-se à escola, o aluno pode aderir ou criticar o que esta propõe. A escola não tem controle sobre a subjetivação do aluno, mas ela se esforça para que ocorra um engajamento deste em seu projeto escolar. No entanto, sempre há uma possibilidade de crítica, de distanciamento do sujeito.

Há ainda outro ponto que esses pais não consideravam - a subjetividade (do aluno, do cidadão) se alimenta das significações construídas socialmente e estas são justamente transmitidas pelas instituições.

\subsubsection{Atendimento Psicopedagógico}

Apesar de tentar adaptar-se, Fábio parecia também ambivalente em relação à escola. Tinha até criado um trocadilho com o nome desta, dizendo que se chamava "Apodrecer” (apelido que rimava com o verdadeiro nome da escola). Na devolutiva ao adolescente, propus o seguinte desafio: estar dentro da escola sem ser nerd (usando a sua expressão), sem ter que se conformar ao sistema, sem abdicar de sua subjetividade. 
A proposta era manter-se na escola em que acabara de entrar e procurar, com vagar, durante aquele ano, uma instituição de ensino que mais se adequasse aos seus interesses e às suas necessidades.

Estabeleceríamos projetos com objetivos alcançáveis, para não fazê-lo entrar na sua oscilação entre impotência ou onipotência total frente aos seus objetivos.

Iniciamos o trabalho com jogos lógicos, que exigem um conhecimento das regras e a organização do pensamento, com o fim de elaborar uma estratégia. Fábio ficou bem interessado e, de início, recorria à estratégia do ensaio e erro. Porém, ao me observar jogar, foi se apropriando de alguns procedimentos, pois eu ia "pensando alto" enquanto jogava. Fazia isso para lhe dar referências, para que ele pudesse criar um sistema para resolver os diferentes desafios.

O método para resolver um problema ou para vencer um jogo implica analisar as variáveis que se apresentam, tentar construir formas de controlá-las, no sentido de antecipar a melhor maneira de solucionar o problema. Fábio ficou bastante interessado e iniciamos um trabalho de metacognição, que implica analisar como pensamos, verificar por que um raciocínio não produziu os efeitos esperados, enfim, tentar conhecer os elementos que compõem uma situação e procurar ter consciência e controle daquela situação.

Fábio foi tomando consciência de suas falhas, dentre elas, a inabilidade para registrar as informações ou dados de uma situação. Sem uma referência gráfica, tinha de memorizar muitas coisas e acabava não conseguindo articular todos os dados. Também notamos que fazia deduções prematuras, quando não tinha dados suficientes para tirar uma conclusão.

O objetivo era propiciar situações que favorecessem a construção dos instrumentais do pensamento formal, segundo Piaget, ${ }^{33}$ pois, apesar de freqüentar a escola, costumava ficar alheio ao processo de formalização dos conteúdos, mantendo-se disperso nas aulas e, tampouco realizava as tarefas solicitadas pelos professores. Em suma, não se submeteu às situações de sistematização que possibilitam o estabelecimento de tal instrumental no ambiente escolar.

\footnotetext{
${ }^{33}$ De forma resumida, o pensamento formal consiste em uma descentração, na qual o sujeito se liberta da realidade concreta e raciocina sobre proposições, mesmo que elas não estejam de acordo com suas convicções. Nesse sentido, o adolescente raciocina sobre hipóteses e utiliza noções de proporções, sistemas duplos de referências, probabilidades, combinatórias, entre outros esquemas. A isso Piaget chama de raciocínio hipotéticodedutivo.
} 
No atendimento psicopedagógico, apesar das dificuldades de lidar com tais desafios, Fábio se propôs a construir esses instrumentais, e isso era muito desafiador para ele, pois jamais havia se submetido a uma situação de construção de um sistema, que tinha de ser levado até o fim para ser testado. Sempre raciocinara de forma mais intuitiva. Apesar de ser algo contrário ao seu funcionamento, Fábio se interessava pelos desafios e discussões que íamos realizando.

O trabalho de metacognição foi favorecendo a descentração e, com isso, a possibilidade de avaliar seus pontos falhos, bem como os recursos que já havia adquirido até então. Junto com a tomada de consciência das questões cognitivas, eu procurava apontar como sua postura influenciava tal processo. Mostrava como sua falta de persistência diante de uma dificuldade impedia a reformulação de uma estratégia, ou a ausência do registro das etapas de um procedimento o deixava sem a possibilidade de verificar em que momento havia falhado, etc.

Esse tipo de discussão foi se ampliando para a sua experiência na escola e em casa. Procurávamos analisar sua postura em outras situações, verificando como certas coisas se repetiam: a desistência de manter o esforço para alcançar determinado objetivo, a irritação quando o adulto não entendia que ele necessitava de ajuda, entre outras coisas.

No contato com a escola, verifiquei que haviam percebido o modo de funcionamento de Fábio e estavam conseguindo submetê-lo às regras institucionais: usar o uniforme, levar material escolar e manter-se em sala de aula. O maior problema consistia em suas defasagens pedagógicas.

Nas férias, Fábio veio a duas sessões, mas sua rotina ficou ainda mais vazia sem a escola. Ficava em casa o dia inteiro e trocou o dia pela noite, pois nesse período era mais fácil encontrar pessoas para conversar nos chats da internet. Vale notar que, segundo os pais, ele não tinha amigos reais, mas acreditava ter amigos virtuais. Parecia ser mais fácil estabelecer relações que não precisavam passar pela confrontação com a realidade, pois eram fugazes e não demandavam a tolerância, o cuidado com o outro, enfim, elementos necessários na manutenção de uma relação a dois. De forma geral, Fábio achava que todos tinham de aceitálo do seu jeito, mas não estabelecia uma reciprocidade em relação ao outro.

Parecia que, para ele, a questão da alteridade só se estabelecia pelas diferenças, mas ela não passava pelo estabelecimento das semelhanças, o reconhecimento do outro como alguém que tem necessidades e desejos, e que também é marcado pela falta, tanto quanto si 
próprio. No caso de Fábio, a impressão é de que ele não sabia transigir; o outro, nessa perspectiva, era reduzido a um objeto de gozo, como comenta Joel Birman (2000, p. 177).

A rede da internet se prestava bem para Fábio, no sentido de camuflar sua solidão e reforçar seu modo de funcionamento. Se há uma riqueza em todas as possibilidades que a internet oferece, há também o outro lado - ela estabelece uma relação do tipo dual. Como Dany-Robert Dufour (2005, p. 85) observa, na rede, as relações se dão em um plano horizontal, sem a mediação de um terceiro. Nessa situação, não se interpõe uma instância superior à qual nos submetemos. Assim, cada um fala o que quer, mostra o que deseja, sem nem necessitar revelar a própria identidade. Isso é próprio ao contexto da contemporaneidade, segundo Lipovetsky (2006), e incentiva uma atitude mais descomprometida perante o outro.

A internet parece oferecer tudo: informações, músicas, filmes, mercadorias, comunicação, enfim, ela dá a impressão de que não há a falta. De fato, ela disponibiliza múltiplas possibilidades de entretenimento, levando o jovem a se manter horas conectado, porém, como lembra Dufour (2005, p. 86), ela não dá espaço para aquilo que o sujeito mais necessita (e mais teme), isto é, interrogar-se: - por que tudo isso?

Conversei com a mãe ao telefone e sugeri que procurasse atividades para Fábio realizar não só nas férias, como em sua rotina habitual, para ampliar suas relações sociais e interesses. A mãe pediu que eu sugerisse uma atividade ou aula para ele freqüentar, desde que fosse de baixo custo e apropriado para ele. Indiquei alguns lugares que ofereciam tais opções, mas ela não se mobilizou neste sentido. Notei que os pais tinham um funcionamento peculiar em relação ao filho: ficavam angustiados num primeiro momento, porém, na medida em que contratavam um profissional para trabalhar com o Fábio (no caso, eu e a escola), acabavam por se desincumbir do cuidado com ele. Dessa forma, quem se angustiava era o terceiro, e não os pais.

De fato, geralmente quando os pais contratam um profissional, há uma expectativa de que ele vai cuidar de necessidades específicas do filho. Tal contrato implica uma atribuição em relação ao profissional, entretanto certas questões dizem respeito aos pais, e não ao profissional. Observei que, nesse caso, os pais se desincumbiam de algumas funções que lhes cabiam - como ampliar o universo de trocas sociais, propiciar opções de lazer e cultura - o que parecia uma forma de abandono que se manteve durante todo o tratamento de Fábio.

Com o tempo, notei que essa atitude tinha um benefício secundário: Fábio permaneceria numa posição infantil, necessitando de cuidados especiais por parte dos pais. De 
fato, Fábio era o temporão, e não constituiu com seus irmãos uma fratria, segundo Kehl (2003), ficando excluído da mesma. Segundo o relato dos pais (na primeira entrevista), ele sempre teve um quarto só para si, enquanto os irmãos dormiam juntos. No entanto, freqüentemente procurava os irmãos, indo dormir no quarto deles. Os pais também relataram que os irmãos tinham ciúmes dele, argumentando que o caçula recebia um tratamento diferenciado. Dessa forma, Fábio ficou isolado em relação aos irmãos, e parece ter ocupado o lugar do desejo dos pais.

Notei também que, assim como Fábio acreditava que o outro tinha de se adaptar a ele, unilateralmente, sem ele estabelecer a reciprocidade nas relações, os pais faziam o mesmo - tanto comigo, como com a escola. Não procuravam opções para o filho, acreditando que o outro poderia fazer isso.

Na primeira sessão de agosto, Fábio não compareceu e não recebi qualquer telefonema para justificar a falta. No dia seguinte, liguei para os pais e o pai contou que, no dia anterior, que havia sido o primeiro dia de aula, Fábio fora à escola, mas ficara muito irritado, pois pouquíssimos alunos compareceram. O primeiro dia caíra numa quinta-feira, então, não teve aula "de verdade", já que o quorum havia sido baixo.

Fábio procurara desempenhar o papel de aluno e havia se sentido prejudicado - pelos pais, que o forçaram a ir para a escola, e pela própria escola. Desapontado, Fábio havia se recusado a vir ao consultório, pois decretara que as férias não haviam terminado. Ele não conseguira ainda discriminar os espaços, como se a psicopedagogia e a escola fossem a mesma coisa. Além disso, se ele se sentira traído pelos pais e pela escola, estava fazendo o mesmo comigo. Outra possibilidade era ele estar se resguardando de uma nova traição - de minha parte.

Comentei com o pai que eu estava preocupada com a falta de opções na rotina de Fábio e acreditava que ele necessitava de lugares outros que não a escola e o atendimento psicopedagógico, pois na escola ainda não conseguira encontrar um ambiente social e necessitava de referências. Precisava estabelecer mais trocas entre pares, o que também não ocorria no atendimento psicopedagógico.

Telefonei ao Fábio para combinar a retomada do trabalho e ele logo se prontificou a vir. Naquela sessão, conversamos sobre sua falta e apontei que percebia que estava sendo difícil para ele entrar, de fato, na escola. Isto é, tornar-se um aluno, ainda mais numa escola que não parecia ser o que ele idealizava. Lembrei nosso contrato inicial de fazer daquela 
escola um espaço de transição para ver que lugar se adequava mais ao seu perfil. Isso não excluía a possibilidade de ele descobrir que até aquela escola poderia ser o que estava procurando. Retomamos, assim, o trabalho com jogos lógicos.

Na semana seguinte, Fábio não veio, e, em seu lugar, vieram os pais. Ele não quisera vir, com a justificativa de que "ele não estava melhorando, não estava adiantando o atendimento psicopedagógico". Na verdade, segundo o relato dos pais, estava encontrando dificuldades em acompanhar o conteúdo escolar. Eles contam que Fábio estava agressivo em casa e que estava detestando a escola.

A expectativa de uma “melhora” rápida mostra uma visão mágica dos tratamentos; isso já acontecera antes, quando Fábio abandonara as terapias e os pais nada fizeram a esse respeito. Reforçavam o imediatismo do filho e, pior, reforçavam a crença de que a posição ativa se restringe apenas ao profissional, e não ao sujeito que está sendo atendido. Os pais não o ajudavam a perceber que ele precisava ter uma participação ativa, fazer a sua parte, não só nos tratamentos, como na escola e pela vida afora. Também não procuravam esclarecer que a superação de uma dificuldade exige muito esforço e um processo que demanda tempo.

Digo que Fábio estava muito solto, com uma rotina desinteressante e carente de estímulos. Sua fonte de realização e subjetivação estava toda concentrada na escola, e, como as coisas estavam difíceis naquele ambiente, ele ficava muito resistente e insatisfeito. O pai retoma a idéia de tirá-lo da escola e colocá-lo em um curso técnico, de Web Design, que já vinha pesquisando.

Mostrei-me contrária à idéia de tirá-lo da escola e apontei que eles tinham de sustentar o Fábio naquele momento do processo escolar, e eles poderiam contar comigo naquele sentido. Marquei que, sempre quando as coisas ficavam difíceis, ele criava uma situação para ser convidado a se retirar da escola e não ter que "pagar o preço": defrontar-se com as dificuldades e tentar superá-las. Dessa forma, ele não entrava no jogo escolar, que consiste em respeitar as regras da instituição e desempenhar o papel de estudante - sendo bom ou até mau aluno.

Vale marcar que o valor de aceitar e submeter-se a normas é um aprendizado que não diz respeito apenas à escola, como também, a qualquer instituição. A escola parece ser o primeiro lugar que marca a saída da socialização primária, restrita à família, para o mundo social, de forma mais ampla. No caso de Fábio, nem mesmo esta passagem parecia ter se efetivado. 
Retomei a questão da complementação da avaliação, apontando que parecia ser o momento de procurar um psicanalista ou psiquiatra para verificar se a oposição e a agressividade não estavam configurando um quadro de organização psíquica mais instável, na forma de um transtorno de comportamento, e indiquei uma profissional. Os pais decidiram aguardar. Estavam um pouco reticentes com o trabalho psicoterapêutico, tendo em vista as experiências anteriores. Deixei claro que se tratava apenas de uma avaliação para verificar se seria necessário ou não também um outro tipo de trabalho, pois, muitas vezes, faz-se necessário mais de um atendimento.

Os pais decidiram manter as coisas daquela forma, argumentando que o atendimento psicopedagógico ainda estava se iniciando. De certa forma, eles tinham razão. Porém, estava claro que Fábio necessitava de outras coisas mais. Propus duas opções: aumentar para duas vezes por semana o atendimento psicopedagógico e eles alegaram dificuldades financeiras e de locomoção. Sugeri, então, que procurassem um professor particular, talvez um estudante universitário, tanto para ajudá-lo com os conteúdos escolares, que estavam muito difíceis, como para ele ter contato com pessoas que investem no conhecimento acadêmico, que têm prazer nisso. Enfim, possibilitar outros modelos identificatórios. Eles disseram que iriam providenciar isso.

Combinamos que os pais conversariam com Fábio e entrariam em contato comigo, para ver se seria necessário eu telefonar para ele para retomarmos o trabalho. Não tive qualquer retorno desses pais e, no dia da sessão, tentei entrar em contato com Fábio, mas não consegui. Fiquei à sua espera, bastante preocupada. Senti, contra-transferencialmente, a angústia do abandono que Fábio sofria com aqueles pais. Felizmente, ele acabou comparecendo ao atendimento.

Conversamos sobre o que estava acontecendo. Fábio estava muito descontente com a escola. Em sua opinião, a escola era ruim e eles não ensinavam direito. Projetava na escola a insatisfação consigo mesmo, sem reconhecer a sua parte naquela questão. Segundo ele, na escola anterior era mais fácil e tudo vinha explicado na apostila. Verificamos que, mesmo com aquele material, ele não havia aprendido na antiga escola, pois não havia adquirido os requisitos básicos para dar continuidade à formalização dos conteúdos na nova escola. Também lembrei que seus pais haviam dito que ele sempre perdia as tais apostilas. Fábio reconheceu que tudo era difícil e que isso o deixava muito irritado.

Segundo seus relatos, nas aulas em que não acompanhava os conteúdos, ele perdia o controle e começava a provocar os colegas, a brincar com o professor. Diante daquela 
situação, apontei que ele tinha duas opções: a primeira era trabalhar intensamente sobre o material escolar, e, nesse caso, ou poderíamos tentar fazer aquilo juntos, a fim de identificar suas reais dificuldades, ou ele poderia ter aulas particulares, com um especialista da área. A segunda opção era ele fugir da situação, como havia feito nas outras escolas. Fábio decidiu que iria pedir aos pais para ter aulas particulares.

Apesar do meu apelo e do filho, os pais não providenciaram as aulas particulares. Conversei com o pai e a mãe ao telefone e cada um atribuía a responsabilidade ao outro. Os pais continuavam fazendo o menor esforço possível, e, pior, pareciam boicotar as diminutas possibilidades de superação das dificuldades.

Fábio ensaiou um recurso para entrar no jogo escolar. Aproximou-se de um bom aluno e passou a sentar-se ao seu lado. Muitas vezes, o colega o ajudava a realizar as tarefas que achava difícil. Foi uma tentativa de estabelecer um modelo de aluno para seguir, mas isso não foi suficiente, pois as dificuldades eram crescentes. Podemos depreender que havia um desejo de integração à ordem escolar, mas o custo para concretizar isso era muito alto para ele.

Fábio recebeu as notas e ficou desanimado, pois seu desempenho foi pífio. Talvez, depois de muito tempo, fosse a primeira vez que ele tinha um dado de realidade, pois, na escola anterior, as notas eram "amenizadas" e a chance de recuperação era sempre certa.

Fábio passou a chegar atrasado na escola ou a faltar às aulas. Seus pais não conseguiam fazê-lo acordar para ir à escola. Apesar disso, ele continuava a comparecer ao atendimento psicopedagógico.

Nosso trabalho prosseguiu no sentido de trabalhar com a metacognição a partir de jogos e situações-problemas, e sempre ampliávamos a discussão para a situação escolar. Apontei que as faltas pareciam representar uma fuga, uma forma de não enfrentar a situação.

Mantive-me em contato com a escola e notei que eles estavam sendo bastante flexíveis com Fábio. Quando ele ficava agitado em classe, ficava junto da orientadora educacional, e, se quisesse sair da aula, o professor dava um atendimento individualizado, no sentido de mantê-lo em classe. Se começasse a provocar alguém, eles contornavam a situação, para não chegar a ponto de ser mandado para fora da sala, ou receber uma punição que o liberasse das aulas.

Contei a Fábio que conversei com a escola e eles disseram que ainda havia chances de reverter a situação, mas ela passava pela via do esforço, do trabalho sobre o conteúdo 
escolar. Apontei que comigo ele estava se esforçando, estava interessado nas atividades e conseguia controlar-se quando achava algo difícil, mas notava que isso não acontecia fora.

Apontei que, apesar de querer adaptar-se, Fábio ficava ambíguo e não conseguia controlar-se. Nesse caso, talvez ele necessitasse de mais alguma ajuda e apontei que um atendimento psicoterapêutico seria bom para ele, naquele momento. Argumentei que esse tipo de trabalho ajuda o sujeito a entender os sentimentos e a manter certa estabilidade, quando se sabe que interiormente as coisas não estão bem. Fábio não quis saber disso.

Ligo para os pais para insistir em relação às aulas particulares e apontar que a situação, naquele momento, clamava por uma avaliação complementar. A mãe conta que ofereceram, em nome da faculdade de psicologia que fazia parte da rede de ensino da escola anterior, o tal psicodiagnóstico que haviam cogitado no primeiro semestre.

Interessante notar que todos que conheciam Fábio preocupavam-se e tomavam iniciativas para reverter a situação - a escola atual, a escola antiga e eu. Todos tomavam uma posição no lugar dos próprios pais.

Os pais já haviam respondido afirmativamente à proposta do psicodiagnóstico. Comentei, no entanto, que eles não pareciam estar mobilizados o suficiente para a seriedade da situação. Aquela situação exigia uma maior presteza dos pais. O filho estava faltando havia uma semana da escola, eles não estavam conseguindo exercer a autoridade para fazê-lo ir à escola. Eles tampouco haviam providenciado aulas particulares, a fim de que pudesse acompanhar o conteúdo escolar. Considerei que, na antiga escola, isso não parecia necessário, mas agora isso era urgente.

Eles pareciam não perceber que a situação necessitava de uma atitude mais proativa e firme de sua parte. No tocante às questões emocionais, em vez de procurar um profissional experiente e competente para realizar um diagnóstico diferencial, para verificar se havia ou não perturbação do comportamento ou uma patologia do agir, confiam o filho a um estudante de psicologia. Realizar um psicodiagnóstico, no contexto da clínica universitária, é algo longo e demorado, o que, naquela circunstância, não parecia ser o mais adequado.

Há, aqui, algo que seria oportuno esclarecer. Trata-se de uma família de classe média, que, apesar das dificuldades financeiras, sempre procurou profissionais autônomos da área da saúde e áreas afins. Não quero entrar no mérito sobre o valor do serviço público, em geral, ou do oferecido pelas universidades, porém, naquela situação, não havia tempo a perder e a demanda por uma ajuda emocional no caso de Fábio parecia premente. 
Em meados de setembro, depois de uma semana sem Fábio ir à escola, os pais foram conversar com a coordenadora, juntamente com o filho, sobre sua situação escolar. Depois de um mal-entendido, decidiram tirá-lo da escola.

A fim de compreender melhor esse fato, vou relatar a conversa posterior que tive com a orientadora educacional. Segundo ela, foi descrita a situação escolar de Fábio, ela disse que ainda havia chances de ele ser aprovado e mostrou o que seria necessário para isso. Cabia ao jovem ir à escola e fazer o seu trabalho. O pai queria uma garantia de que a aprovação era certa. A orientadora disse que não poderia responder a isso, dependia do desempenho do Fábio.

O pai perguntou, então, caso ele fosse reprovado, se a escola o aceitaria na mesma série no ano seguinte. Ela disse que sim. O pai perguntou se o filho saísse da escola, naquele momento, se eles poderiam ser dispensados de pagar as mensalidades até o fim do ano, para retornar no ano seguinte. A orientadora disse que teria de se informar, junto à secretaria. Ao final, ficou combinado que Fábio retornaria à escola e faria o que era esperado dele.

Segundo os pais, no dia seguinte da entrevista com a escola, Fábio não quis acordar. A mãe insistiu e chegou a ofendê-lo. Ele deu um tapa na mãe. Os pais deixaram o filho em casa e foram trabalhar. Mais tarde, o pai voltou para casa, conversou com Fábio e, segundo ele, chegou à conclusão, junto com o filho, de que este iria parar de freqüentar a escola naquele ano.

O mal-entendido se deu ainda naquele dia, quando os pais receberam um comunicado da escola, avisando que o documento da transferência estaria pronto, dentro de um prazo determinado. Apesar da decisão de deixar a escola, quando esta respondeu à solicitação, os pais ficaram “desapontados”. Segundo a orientadora, a escola não estava desligando o aluno, estava apenas comunicando que, se os pais quisessem, a transferência do aluno seria providenciada. Para os pais, a escola voltou atrás. Enfim, o mal-entendido representou a justificativa dos pais para romperem com a escola.

Vale marcar que esse episódio da entrevista e da decisão de abandonar aquela instituição de ensino é revelador da forma como esses pais encaram a escola: como um bem de consumo. Querem a certeza do que está sendo oferecido, como se o bem que ela oferece fosse uma mercadoria. Além disso, os pais acreditam que o contrato implica obrigações somente no que diz respeito à escola, e não aos pais e alunos. No momento em que percebem 
que terão de insistir na mobilização do filho para com a escola, abandonam a instituição, que, na visão deles, é uma empresa.

Vale marcar que, na entrevista com a orientadora, o pai colocou a hipótese de o filho abandonar a escola, e Fábio compreendeu aquela mensagem. Assim, apesar de dizer que faria a sua parte diante da orientadora, no dia seguinte, Fábio fez o contrário. Mostrou que não queria entrar na lógica do ofício escolar e teve o pai como cúmplice.

Os pais vieram conversar comigo depois disso tudo, na intenção de refletir sobre o que poderia ser feito naquele momento para ajudar o filho. Insisti para que eles procurassem outra escola, ou, caso não quisessem isso, contratar um "tutor" para estudar em casa com ele. Os pais não queriam mais investir em estudo para o filho naquele ano.

O pai disse que Fábio não ficaria sem fazer nada. Ele desenvolveria um projeto de informática junto ao pai, no escritório, e faria o que este determinasse. Fábio seria matriculado em um curso de Web Design. Entretanto, este só começaria em outubro e seria apenas uma vez por semana - aos sábados, o dia inteiro. Por mais um mês ele não teria qualquer outra referência a não ser eu, a estudante que estava realizando o psicodiagnóstico e a família, visto que a empresa em que estava “estagiando” era familiar.

Os pais disseram estar mais vigilantes com Fábio, pareciam preocupados por ele ficar muito solto. Contaram que certo dia em que estava sozinho em casa pintara a parede do seu quarto e, quando os pais retornaram à casa, descobriram que ele havia inalado uma lata de solvente e havia ficado meio sonolento.

Quando Fábio não ia para a empresa com os pais, ficava o tempo todo na internet, jogando Grand Theft Auto (GTA). ${ }^{34}$ Corresponde ao nome que a polícia americana dá para roubo de carro. Segundo a Wikipedia, é uma série de jogos de computador e videogames em que o jogador encarna diversos personagens: um criminoso, membro de uma gangue, médico, etc. Nesse jogo, o indivíduo que joga tem a liberdade de fazer o que quiser, desde realizar um crime, perseguir policiais, entrar em guerras de gangues, até namorar.

Os pais achavam o jogo muito violento e, de fato, ele alimenta a onipotência do jovem, uma vez que não há lei, já que cada um faz o que quiser. Em vez de tentar conhecer melhor o jogo, explorá-lo com o filho, ver todas as suas possibilidades, para ajudar Fábio a ter uma visão crítica do mesmo, decidiram tirar o computador de casa. Passaram a acompanhá-lo quando ele ia a lan houses, para conhecer seus companheiros de videogame.

\footnotetext{
${ }^{34}$ O GTA foi criado pela Rockstar North e é distribuído pelo mundo todo.
} 
Os pais pareciam oscilar entre o abandono e a superproteção. Ora o filho ficava livre para fazer o que quisesse, como pintar a parede do quarto, ora não podia ficar sozinho numa lan house. Parecia que a falta de clareza dos pais redundava na instabilidade do filho.

Apontei que Fábio estava desorientado, queria descobrir coisas, buscar novos referenciais identificatórios, e era óbvio que não estava encontrando caminhos produtivos para isso. Falei da necessidade de que os pais refletissem sobre suas atitudes, inclusive em relação ao psicodiagnóstico que estava sendo realizado na faculdade de psicologia. Os pais decidiram mantê-lo, apesar de já apresentarem críticas em relação à profissional desse serviço.

Contaram que, na entrevista inicial, eles tocaram em um fato passado que julgavam sem importância. Segundo eles, quando Fábio estudava na escola católica tradicional, em certo período, ele ficou em recuperação. De acordo com o relato, por acaso, o professor derrubou uma prova em branco e o jovem a pegou, disfarçadamente. Eles nem chegaram a comentar que o filho talvez tenha roubado esse documento do professor.

Ao examiná-la melhor, Fábio notou que aquela seria a prova da recuperação. Levoua para casa, mostrou-a aos pais e o pai o ajudou a resolvê-la, pois sabia que o filho corria o risco de ser reprovado. A psicóloga fez uma crítica em relação a tal conduta e o pai disse que fez "o que faria qualquer pai naquela situação”.

Comentei que os pais haviam demonstrado grande preocupação, no início do nosso contato, em relação ao caráter ético do filho. Falei que os filhos aprendem tais princípios não somente pelo discurso, mas, sobretudo, pelas atitudes dos pais. No entanto, havia a possibilidade de os pais haverem transmitido uma mensagem para o filho de que a lei não vale para todos - dependendo da situação, ela pode ser burlada. Os pais foram reticentes em relação a esse comentário.

Mais uma vez, sugeri que eles procurassem atividades para ocupar o tempo do filho, como inglês, capoeira, ou outros cursos para não deixar Fábio tão isolado. Outra opção seria intensificar o atendimento psicopedagógico. O pai alegou ser impossível qualquer possibilidade naquele momento, pois queriam economizar para pagar o curso de informática e também para comprar um equipamento para Fábio poder se aprimorar como $D$ ’J.

Vale notar que não havia nenhum estímulo para o desenvolvimento de atividades mais sistemáticas, como se a formalização de conteúdos fosse algo maçante e que não trouxesse benefícios. Mantinham essa crença, mesmo quando ficou muito claro no 
diagnóstico psicopedagógico que Fábio apresentava uma grande carência na sistematização do pensamento. Acreditavam que o uso que se faz dos conteúdos acadêmicos se aplicava somente ao contexto escolar, e não para a estruturação do pensamento.

Ao contrário, a transmissão e sistematização dos conteúdos promovem a ampliação do pensamento, e, no caso dos adolescentes, ajudam a estruturar o pensamento formal. Sobre a abertura mental que a aquisição do pensamento formal propicia, David Elkind (1975, p. 71) mostra que o jovem pode construir argumentos que contrariem os fatos e verdades que lhe são impostos, e, mais importante, pode tomar seu próprio pensamento como objeto de questionamento. Propicia a autocrítica. Era justamente isso que o faltava ao Fábio e, por extensão, aos próprios pais.

Os pais pareciam não conseguiam refletir sobre suas atitudes e sobre os efeitos das mesmas. Não percebiam que deixavam o filho à deriva, sem referências de autoridade. Não atinavam que isso era desestruturador para um adolescente. Os pais não tinham disponibilidade de aprendizagem e não reconheciam como reforçavam uma posição infantil no filho. Fábio era refém do desejo dos pais ou do próprio desejo.

Isso nos remete à função paterna e à questão da transmissão da lei. Esse pai, por diversas vezes, transgrediu a lei ou tentou burlá-la. No episódio da ajuda ao Fábio para fraudar a prova, o pai desempenhou um papel ativo na transgressão à lei.

Há situações em que os pais sabem que os filhos transgridem as normas, mas esses momentos cumprem o papel de ritos de passagem - a primeira bebedeira, a pichação num muro, etc. Esses casos são considerados “desvios tolerados”, segundo François Dubet (1996a), e neles os pais não assumem um papel ativo. Nessas situações, as transgressões são restritas a um campo e são relativamente controladas pelos adultos. São toleradas, pois, como afirma Souza (2004), tais rituais possibilitam ao jovem afirmar o seu lugar e sua identidade no mundo adulto, porém isso não pode lhe parecer que se trata de algo que tem a anuência dos adultos, o que representaria para o jovem uma atitude de obediência, que diz respeito a um comportamento tipicamente infantil.

Houve também uma tentativa de burlar a lei na última entrevista dos pais com a escola. Não houve um pedido explícito, mas o pai perguntou à orientadora se, apesar da grave situação escolar de Fábio, ela poderia garantir que o filho seria aprovado. Em outras palavras, estava querendo saber se dava para burlar o processo avaliativo e fazer o filho ser aprovado de qualquer maneira. 
Outro episódio de transgressão foi o fato de o pai de Fábio tirá-lo da escola. Desrespeitou algo estabelecido na constituição desde 1934 e previsto na lei do Estatuto da Criança e do Adolescente, que obriga todos aqueles que estão em idade escolar a freqüentar a escola. Para esse pai, a lei não era impessoal, ele só a seguia quando lhe convinha.

Procurei mostrar esses pontos para os pais, mas eles mantiveram a decisão de tirar o filho da escola. Naquele momento, percebi que meu principal foco deveria ser Fábio, pois esses pais não pareciam querer reformular suas referências.

Apesar de estar excluído do processo escolar, ainda havia muito a trabalhar com ele. As mesmas questões de aprendizagem retornariam assim que retomasse à vida escolar. $\mathrm{O}$ atendimento psicopedagógico consistiria no único espaço para tratar da questão da inserção no mundo da cultura, da submissão a regras, da formalização do pensamento. Estabelecemos, assim, um novo projeto de trabalho. O atendimento, a partir de então, seria centrado em projetos, buscando colocá-lo na lógica do trabalho, do esforço, por meio da realização de coisas do seu interesse. ${ }^{35}$

Fábio vinha falando da vontade de mudar o seu quarto; já havia pintado uma parede, manifestava o desejo de pôr as próprias marcas no seu espaço. Falava que queria fazer um mural, entre outras idéias. Tinha a necessidade de entrar numa posição ativa, de produzir coisas com as quais pudesse se identificar.

Esse desejo de pôr suas marcas, de entrar em ação, além de ser uma necessidade dos adolescentes, aparentava constituir uma importante forma de produção, de fazer algo em que pudesse se reconhecer, já que Fábio não tinha mais a possibilidade de fazer isso no lugar por excelência destinado a este fim - a escola. A escola propõe redações, desenhos, trabalhos, que representam formas de o aluno se reconhecer, de ver suas qualidades e suas limitações.

O atendimento psicopedagógico converteu-se no único espaço de produção e de subjetivação. A subjetivação é concebida, aqui, conforme Dubet e Martuccelli (1996), como o trabalho do sujeito, uma elaboração por meio da qual ele constrói uma identidade, uma coerência e um sentido. Sem tal possibilidade, restaria apenas a passagem ao ato ${ }^{36}$. Nesse sentido, a agressividade em relação aos pais parecia estar relacionada com essa impossibilidade - como não tinha condições de elaborar seus conflitos, de simbolizá-los,

\footnotetext{
${ }^{35}$ O leitor pode perguntar-se por que não propus isso desde o início, no entanto, quando Fábio estava inserido na escola, suas defasagens eram tais, que acreditei que a atividade com jogos lógicos seria mais próxima para que ele estabelecesse as devidas relações com a formalização do conteúdo escolar.

${ }^{36}$ Para Mônica do Amaral (2006a), trata-se de uma atuação-limite, a irrupção do mundo psíquico no mundo externo ou no próprio corpo, sem ser acompanhada de elaboração mental.
} 
sentia a urgência de fazer coisas, e, como não havia muitas opções, utilizava o recurso da realidade perceptivo-motora, ${ }^{37}$ segundo Philippe Jeammet (1994, p. 4).

Combinamos, assim, planejar e executar objetos decorativos para seu quarto, a começar por um móbile, que Fábio vira numa festa clubber. A intenção era levá-lo a pesquisar modelos, técnicas, materiais, estabelecimentos comerciais e culturais que pudessem propiciar referências para seus projetos. Junto com isso, ele aprenderia coisas e, ao final, teria um produto por meio do qual poderia se reconhecer e se realizar.

Passei a incentivar Fábio a ir a exposições com mostras relativas aos seus interesses, a procurar sites na internet, livros, dentre outros produtos culturais, onde pudesse aprofundar seus conhecimentos. O objetivo era fornecer referências culturais, com as quais pudesse se identificar, estabelecendo marcos para a sua subjetivação.

Quanto ao móbile, Fábio fez uma descrição, mas, como era difícil visualizar como seria, pesquisou na internet, encontrou alguns modelos, trouxe algumas imagens e tentamos descobrir a melhor forma e o material mais adequado para executá-lo.

Na hora de realizar o projeto, Fábio quis desenhá-lo no papel e deteve-se com a questão do espaço projetivo. Notei que representar uma figura tridimensional no papel era muito difícil para ele e propus uma etapa exploratória, de familiarização com a geometria plana e espacial. Trabalhamos inicialmente no espaço plano, explorando Tangram, ${ }^{38}$ para ampliar seu repertório nas relações infra-lógicas. Também propus a ele a construção de diferentes formas de representar um cubo no plano, utilizando papel quadriculado. O desafio era imaginar e desenhar o modelo e somente testá-lo ( recortar e montar os cubos) no final, o que era bem difícil para Fábio, que queria fazer justamente o inverso.

Por fim, trabalhamos com um material tridimensional chamado Structuro, ${ }^{39}$ que explora a estruturação do espaço pela observação, a análise e a execução de construções nos planos topológico, euclidiano e projetivo ${ }^{40}$. Primeiro, o sujeito faz uma construção com os blocos e depois esta é representada graficamente em um, dois e três planos no papel

\footnotetext{
${ }^{37}$ Isso diz respeito ao campo das atitudes concretas e do comportamento, sem a mediação da palavra, como as passagens ao ato.

${ }^{38}$ Segundo Macedo, Petty e Passos (2005), trata-se de um jogo milenar, de origem chinesa, que trabalha com as relações espaciais.

${ }^{39}$ Structuro, da empresa francesa Nathan, São cubos com faces opostas da mesma cor: vermelho, amarelo e azul. Há fichas com desenhos que mostram as construções vistas de frente, mostrando a face vermelha. Outras fichas mostram os cubos vistos de lado, e a face é azul, e, por fim, desenhos vistos por cima, e a face é amarela. Há fichas que têm várias informações, mostrando a construção com cubos em um, dois ou três planos.

${ }^{40}$ Esses planos correspondem, respectivamente, ao espaço unidimensional, bidimensional e tridimensional.
} 
quadriculado. Em seguida, o sujeito executa algumas “plantas”, sendo que há indicações que são planas, outras no plano bidimensional e outras, ainda, no plano tridimensional.

Depois dessa etapa exploratória, pesquisamos sobre os sólidos geométricos, a fim de constituir mais referências para montar o seu protótipo.

Verificamos que há os sólidos platônicos, os sólidos de Arquimedes, conhecimentos que se conservam desde a Antigüidade. Constatamos que o modelo que Fábio desejava construir era uma geodésica, mais precisamente, um dodecaedro: um poliedro de 60 faces. Discutimos e vimos que seria muito cansativo construí-lo e ele decidiu montar um icosaedro, um poliedro de 20 faces, que também pode ser chamado de “tetraedro snub”. Para simplificar, o chamamos de tetraedro.

Em seguida, Fábio fez cálculos e chegou a um protótipo em miniatura e, finalmente, passamos para a fase de execução. Seu tetraedro era constituído por 20 triângulos de varetas de madeira, unidos por "garrotes" de borracha. ${ }^{41}$ Esses triângulos iam se articulando, tal como uma colcha de retalhos e, entre as arestas, Fábio quis trançar linhas coloridas, como nos móbiles que vira nas danceterias.

Primeiro ele construiu a estrutura de madeira e depois partiu para o trançado. Durante sua execução, muitas vezes a estrutura se desestabilizava e uma vareta se soltava Fábio ficava impaciente e queria desmanchar tudo. Sua tendência era tomar o todo pelas partes: se uma parte estava ruim, então tudo estava ruim. Nesses momentos, eu procurava ajudá-lo a fazer a discriminação, apontando que apenas uma parte tinha se desfeito, e não toda a estrutura. Ao verificar que apenas uma ligação havia rompido, percebia que era possível reverter o problema. No início, como ficava muito irritado, não conseguia executar o reparo e eu mesma o fazia. Com o tempo, ele assumiu essa tarefa.

Além da questão da falta de discriminação parte-todo, havia também certa idealização por parte de Fábio. Na sua lógica, tudo tinha de sair perfeito, caso contrário, não valia nada. Marquei que tal situação se assemelhava à sua postura em relação à escola. Como a escola não era aquilo que havia idealizado, era um "lixo". Não havia um meio termo. Argumentei que uma escola poderia não ser perfeita, porém, certamente, tinha suas

\footnotetext{
${ }^{41}$ Material utilizado em hospitais e laboratórios para realizar exame de sangue. É usado para apertar o braço do paciente e facilitar a localização de uma veia para coletar o material (sangue) para o exame. Vi modelos utilizando tais materiais em uma apresentação sobre geometria espacial de Roberto Pompéia, que costuma apresentar-se em escolas e faculdades.
} 
qualidades. Nosso trabalho enfocava a aprendizagem, mas, também, sua experiência de forma mais ampla.

Como afirmado anteriormente, a idealização mantém relação com o narcisismo, pois ela aponta para um objeto imaginário, fruto do desejo do sujeito. No caso de Fábio, ele estava colocado no lugar do ideal dos pais, sem a mediação de terceiros, de dados da realidade e da cultura. Da mesma forma, a relação que o jovem estabelecia com o objeto idealizado era com uma imagem puramente visual, sem consistência. Tratava-se de uma imagem fixa. De acordo com Hugo Bleichmar (1991), isso diz respeito a uma relação dual, narcísica, em que o objeto idealizado é dotado da fixidez, ele não pode ganhar outras significações. Em outras palavras: a escola idealizada tem de ser exatamente aquilo que Fábio deseja, sem mediações, sem dados da realidade. Nesse jogo de tudo ou nada, este último sempre acaba prevalecendo.

Para Jeammet e Corcos (2005, p. 71), o problema da idealização é que ela diz respeito ao objeto de investimento e não demanda do sujeito um trabalho de transformação e de deslocamento dos fins pulsionais, ao contrário da sublimação ${ }^{42}$. Os autores também alertam para a dupla de opostos: no caso da idealização, seu oposto é o denegrimento. Assim, se o objeto não satisfaz o ideal, ele é imediatamente colocado no extremo oposto - é uma porcaria.

Constantemente tenho de apontar ao Fábio a necessidade de perseverar, de manter o esforço, mesmo quando algo sai errado. Dou o exemplo de um móbile que tem em nossa sala de trabalho. Ele é equilibrado por varetas e não deve ter sido fácil para quem o fez encontrar o ponto de equilíbrio. Provavelmente, o executor deve ter tentado inúmeras vezes até chegar àquele ponto, mas, se desistisse da tarefa, o móbile não estaria lá. Aponto que aquela experiência pode ser uma aprendizagem para o seu futuro curso de informática, o qual parece ter um enfoque profissionalizante, é destinado a pessoas que querem se especializar e que têm disposição para isso. Lá ele não vai poder “zoar” ao sentir uma dificuldade, como fazia na escola.

Fábio passa a ocupar o seu tempo em casa explorando o software que ganhou na matrícula do curso de Web Design. Enquanto isso, sua rotina está muito entediante no escritório dos pais. Clama por agir e diz que quer fazer em casa objetos para o seu quarto, além do móbile, que está fazendo comigo. Conto que fui a uma exposição no SescBelenzinho, “Brincadeiras de papel”, e lá vi móveis de papelão, de embalagens Tetrapack

\footnotetext{
${ }^{42}$ Como já afirmamos, a sublimação consiste na transformação das pulsões para a obra cultural, para produtos valorizados socialmente.
} 
bem interessantes. Ele vai à exposição, fica instigado e passa a fazer projetos para a sua cama, que é uma cama "turca”. Quer fazer uma nova cabeceira com uma fileira de garrafas PET com água e anilina, com cores “cítricas”, típicas do universo clubber.

Vai ocupando seu tempo entre preparar-se para o curso e fazer objetos decorativos para o seu quarto. Não fala nada sobre sua vida escolar no ano seguinte. Os pais não estão mobilizados em relação a isso, muito menos Fábio.

O curso de Web Design inicia-se no fim de Outubro e passa a ser um dos temas das nossas conversas. No primeiro dia, Fábio fica admirado, pois os alunos são mais velhos do que ele e trabalham. A aula é expositiva e ele consegue controlar-se, ficando quieto em classe o dia inteiro. Comento que ele é capaz disso e ele responde: “- É porque aquilo me interessa!”. Conta que fez anotações em sua apostila. Passa a valorizar o registro das informações. Diz que faz perguntas quando tem dúvida. Experimenta, pela primeira vez, o papel de aluno interessado e ativo.

Na semana seguinte, Fábio aparece com um gorro, cobrindo o cabelo. Relata que não teve aula, pois fora feriado no sábado. Também conta que a empregada doméstica jogou fora suas garrafas coloridas. Aponto que foi a semana das “não-realizações”, em oposição à semana anterior. Em seguida, ele tira o gorro e mostra que descoloriu o cabelo. Digo que aquilo parece ter sido a sua única realização da semana, mas que esta me parece um protesto, uma forma de manifestar o seu descontentamento. Ele não diz nada a esse respeito.

Ligo para os pais para perguntar se estão procurando escola para o ano seguinte, lembro que a época para reservar matrículas é em setembro e estamos no final de outubro, enfim dou parâmetros de como os outros pais lidam com isso. A mãe diz que estão vendo algumas coisas na internet, mas nada muito sistemático. Conta também que tiveram a devolutiva do psicodiagnóstico e foi “interessante”, mas não entra em detalhes. A indicação foi de uma psicoterapia, mas só poderia acontecer no ano seguinte, no semestre letivo seguinte. Falo que gostaria de conversar com os pais para saber sobre tal avaliação e para encaminharmos algumas questões. A mãe é reticente, diz que vai me ligar quando for possível.

Com Fábio, vamos executando o móbile, parte por parte. Ele fica mais persistente e cuidadoso, tal como um artesão. Enquanto isso, conversamos sobre suas coisas. Introduzo o tema escola e noto que ele passa a relativizar essa idéia. Refletindo sobre a última escola, se conscientiza de que o problema não era a escola em si, mas sua postura. Diz que implicou 
com ela, não se dispôs a fazer parte da mesma. Fica arrependido de ter "zoado" na escola anterior (a da rede de ensino) e de ter inviabilizado sua permanência nela. Gostava do clima de liberdade que lhe era dado. No entanto, reconhece que não aprendeu nada naquela escola.

Comento que ele parece o oposto de uma figura da mitologia grega - Midas. Conto que Midas era um rei que foi agraciado com um poder: tudo o que tocava virava ouro. Com Fábio, parecia o contrário, todas as escolas viravam uma porcaria. Ele percebe que a questão não é a escola, e sim, sua postura. Começa a desenvolver uma visão menos idealizada das escolas e percebe que sua disposição (seu desejo) é que faz com que as coisas sejam boas ou ruins.

Conta que a última aula do curso foi chata e que ele só não se levantou pois todos os colegas são adultos. Quer preservar sua imagem. Aponto que isso mostra que ele pode se controlar, se quiser. Lembro a ele de uma sessão em que conversamos sobre a possibilidade de o curso apresentar desafios e não ser interessante o tempo todo. Falamos inclusive sobre o fato de que ele teria partes difíceis, que exigiriam esforço e persistência. Mostro que ele pode aprender várias coisas no curso sobre si mesmo. Ele poderia se observar e ver como reagiria diante das dificuldades e avaliar os efeitos: verificar o que era produtivo e o que não era produtivo na sua postura.

Fábio diz que o que o faz ficar controlado é a "grana”, o dinheiro que seu pai está gastando com esse curso. Essa fala sobre o dinheiro remeteu-me à fala do pai, a respeito do profissional de uma editora que fez uma apresentação na escola para “vender livros”, como se tudo em educação fosse atravessado pelo dinheiro. Nessa lógica, não há espaço para o valor de uso do saber, ele sempre é visto pelo valor de troca.

Em relação ao valor despendido em sua formação, sugiro que ele pode pensar de duas formas: o dinheiro como uma despesa, sem um retorno, como aconteceu em outras situações (escolas onde ele não aprendeu, não aproveitou), mas também como um investimento, um dinheiro que vai ter um retorno na forma de conhecimento e de expertise, algo que pode até lhe propiciar uma profissão.

Fábio argumenta que isso lhe parece muito distante. Falo que tudo é um processo e, muitas vezes, os resultados não são tão imediatos. Procuro mostrar que ele ultimamente tem conseguido ficar mais paciente e parece que as coisas têm ficado mais produtivas ao seu redor: o móbile, o curso e os objetos de decoração que está fazendo para o seu quarto. 
Quanto ao móbile, este parece um produto do tear de Penélope - Fábio trabalha sobre ele todas as sessões, mas sempre tem novas idéias - muda a cor de um fio, introduz uma pequena pirâmide dentro, enfim, aprimora-o cada vez mais, e nunca o finaliza. Aponto isso e ele diz que está gostando do produto, e que se sente bem ao executá-lo. Fábio podia se reconhecer naquela produção, ver algo de positivo saído de suas mãos, de algo que criara.

A possibilidade de escuta e de reflexão sobre suas coisas parece ainda se restringir à sua experiência no atendimento psicopedagógico, mas não se generaliza para o contexto familiar. A mãe me telefona e diz que ele está bem agressivo com os pais. Eles foram ao médico da família e este sugeriu uma avaliação psiquiátrica. Comento que acho importante os pais terem chegado a essa conclusão, era isso o que eu vinha solicitando nos últimos dois meses. Lembro que a rotina de Fábio era totalmente desprovida de sentido e de estímulos e que ele estava perdido, clamando por uma referência. Devia ser difícil para ele sustentar essa situação. A mãe afirma que isso aconteceu porque Fábio quis sair da escola. Acrescento: os pais não se opuseram a isso, ao contrário, eles próprios abriram tal possibilidade.

Falo para a mãe que reconheço que, num primeiro momento, sair da escola aliviou o relacionamento de Fábio com os pais, porém logo ele ficou desprovido de referências, o que é perigoso para um rapaz de 14 anos. Digo que psicopedagogia uma vez por semana e um curso aos sábados era muito pouco para um adolescente nessa etapa da vida, com tanta energia e tantos anseios. O escritório dos pais acabou sendo uma grande chateação, pois não havia nada de interessante para ele fazer. Além do mais, o curso de Web Design não parecia muito adequado ao Fábio, pois era bem especializado e ele não tinha a base necessária. Em vez de encontrar nesse curso um grupo para compartilhar os mesmos interesses, se sentia inibido com a idade e a maturidade dos colegas. Novamente Fábio não se integrava a um grupo e se isolava.

Comento que eu experimentara a mesma situação que Fábio em relação aos pais. Eles também me deixavam sem referências - não davam retorno sobre o psicodiagnóstico que havia sido feito, sobre a procura de escolas, não mantinham nossos combinados.

A mãe fala que vai tentar marcar um horário comigo, e avisa que Fábio virá somente uma vez mais, a fim de reduzir despesas, pois agora eles vão ter muitos gastos com a avaliação psiquiátrica. Vale destacar que já estávamos na primeira semana de dezembro e o móbile estava praticamente pronto. 
Na sessão seguinte, disse ao Fábio que, de acordo com a decisão dos pais, aquela seria a última sessão e ele completou: “- Desse ano, né?”, supondo que continuaríamos o atendimento no ano seguinte. Falei que parecia que sim, pois tínhamos muitas coisas para fazer, entretanto isso dependeria de outros fatores. Fábio trabalhou bastante para finalizar o móbile e contou que descobriu um site de móbiles incríveis, inclusive mandou para mim por e-mail umas imagens bem interessantes. Disse que estava cheio de projetos de móveis e objetos de decoração para o seu quarto. Decidira, junto aos pais, continuar o curso de Web Design em outra turma, no mês de janeiro, com aulas diárias. Ainda não haviam decidido nada em relação à escola do ano seguinte.

Ele leva o móbile para casa para decorar o quarto e eu digo que essa construção pode servir como um lembrete das coisas que aprendeu a fazer e também do que aprendeu sobre si mesmo, por meio de nosso trabalho.

No ano seguinte, fui informada pelo pai que Fábio fora matriculado numa escola do bairro e iniciara um tratamento com o psiquiatra, duas vezes por semana. Os pais decidiram suspender o atendimento psicopedagógico.

Fazendo um balanço sobre este estudo de caso, gostaria de reforçar minha posição em relação à condução da intervenção psicopedagógica junto a essa família. Sempre reivindiquei que Fábio permanecesse na escola e, mesmo quando ele saiu, sempre coloquei essa possibilidade em seu horizonte. O leitor poderia levantar a hipótese de que minha visão fosse muito "escolarizadora”. Talvez os pais estivessem optando por direcionar o filho para um caminho menos acadêmico. Porém, essa opção me parecia muito precoce, uma vez que Fábio nunca havia sido reprovado e não estava tão defasado, do ponto de vista da série escolar, para a sua idade. Também não havia problemas cognitivos mais sérios que o impedissem de freqüentar o ensino regular.

Fábio foi sempre muito participativo e colaborador no atendimento psicopedagógico, que, embora não fosse voltado para o conteúdo escolar, sempre foi permeado pelos marcos culturais. Ademais, no desenho do Par Educativo, Fábio representou uma classe com um aquário enorme, cheio de peixes e animais marinhos, fazendo, segundo ele, uma escola "diferente". Ele não parecia estar desistindo da escola - pelo contrário - parecia estar fazendo um grande investimento na mesma. Vale assinalar que ele havia falado que a classe que havia representado era do $1^{\circ}$ ano do Ensino Médio. Apesar de estar fora do jogo escolar, ele me parecia desejar estar dentro. 
No entanto, não havia por parte dos pais um interesse em prepará-lo para o reingresso na escola - aquela ocasião poderia consistir em uma oportunidade de rever suas defasagens escolares, por meio de aulas particulares. Qualquer proposta de mediação desse jovem com o saber escolar era logo descartada pelos pais. O desinvestimento era tal, que, durante todo o tratamento, quando eu perguntava se eles estavam fazendo uma pesquisa de escolas para o ano seguinte, eles eram muito vagos, diziam que estavam procurando pela internet, mas nada de efetivo foi feito, tanto é que em Dezembro eles ainda não haviam escolhido uma escola para o filho estudar no ano seguinte.

Retornando à afirmação inicial sobre o eventual fracasso desse atendimento, tendo em vista o tratamento ter sido interrompido antes do seu término e também pelo fato de que o jovem estava apresentando um comportamento muito agressivo na família, penso que esse caso foi fracassado em termos. Primeiro, porque, apesar da instabilidade e do vazio que a vida de Fábio adquiriu após ter deixado a escola, o tratamento psicopedagógico passou a representar o único espaço de busca de estabilidade, de reflexão, de contenção e de criação. Se, no início, esse jovem utilizava como mecanismo de defesa predominante a idealização, gradativamente passou a investir sua libido em objetos valorizados socialmente, introduziu-se no mundo das trocas simbólicas, da cultura, fazendo uso, portanto, do mecanismo da sublimação. Não é que tenha se curvado à ordem escolar - longe disso. Entretanto, entrou na lógica do trabalho escolar, o que significa o primeiro passo para tornar-se um aluno.

Em relação à intensificação de um sintoma que já havia sido observado, o do comportamento, continuo acreditando que, na época do diagnóstico, a prioridade era a questão da aprendizagem. Minha falha pode ter sido a de não insistir ainda mais na busca por um segundo atendimento (psicoterapêutico), pois, muitas vezes, o sujeito necessita de mais de um. Muitos profissionais se recusam a atender um paciente quando as condições se mostram desfavoráveis, eu poderia interromper o atendimento. No entanto, meu temor era que esses pais não procurassem nenhum profissional e Fábio ficasse realmente abandonado. Para concluir essa questão, vou recorrer à Sara Paín:

Diz Freud que o que resta da doença depois da desaparição do sintoma é apenas a disposição para formar novos sintomas; entretanto quando se trata da aprendizagem e das atividades cognitivas, o reforço destas deixa o sujeito numa melhor disposição para elaborar seu trauma, caso se submeta a uma psicanálise, e, para encontrar vias de satisfação e de sublimação na sua vida cotidiana... (1985, p. 77) 
Por fim, acredito que esse caso é exemplar para a reflexão sobre o papel do ambiente na organização psíquica do jovem. Dependendo da forma como este responde às demandas do sujeito, pode exercer uma função de sustentação no sentimento de continuidade do ser, na acepção de Winnicott. ${ }^{43}$ Caso contrário, pode funcionar como um desestabilizador para o adolescente, impedindo sua organização psíquica. No caso de Fábio, acredito que tenha ocorrido justamente esta segunda possibilidade, a ponto de ele acabar necessitando de uma intervenção psiquiátrica.

\subsection{Otto - Pai e filho em uma relação fraternal}

\subsubsection{Primeira entrevista com o pai}

O pai veio à entrevista sozinho. Procurou-me depois de conversar com sua analista a respeito das dificuldades escolares do filho. A indicação do meu nome foi da própria analista. Estava bem ansioso para a primeira entrevista e atrasou-se 45 minutos, pois, apesar de ter o meu endereço, foi a outro consultório na mesma rua onde está situado o meu, e demorou a perceber o mal-entendido.

Tem 42 anos, é professor universitário e provém de uma família de tradição acadêmica no Nordeste. A ex-mulher também é de origem nordestina e mora na Itália há dez anos. O casal se separou há dez anos e ambos constituíram novas famílias. O pai tem dois filhos pequenos e a mãe teve um filho no ano anterior.

Otto é um adolescente de 16 anos, de família de classe média, cursando o $1^{\circ}$ ano do Ensino Médio. A escola onde estuda é reconhecida como uma escola de ensino renovado, de orientação construtivista, situada na zona Oeste de São Paulo, e sua clientela é constituída por filhos de intelectuais e profissionais liberais.

A cultura psicanalítica é bastante valorizada pela família paterna. O avô fez análise “a vida toda”, de acordo com o pai. Assim como o avô costumava fazer interpretações psicanalíticas sobre a relação de Otto e o pai, este também faz interpretações sobre seu filho.

Otto está morando em São Paulo há um mês. Pai e filho voltaram a morar juntos depois de 10 anos, quando o casal se separou. Na verdade, houve uma outra tentativa de

\footnotetext{
${ }^{43}$ Experiência que o bebê vivencia de segurança e estabilidade em reação ao ambiente (personificado pelos pais). Para Winnicott, nessa experiência, é o ambiente que se adapta à criança, e não o contrário.
} 
morarem juntos. No intervalo entre os dois casamentos, o pai teve uma rápida relação conjugal e levou o filho consigo, mas não deu certo. Separou-se e o filho foi morar com os avós

A queixa do pai em relação à aprendizagem de Otto diz respeito ao domínio da leitura e escrita. Segundo o pai, o filho escreve mal, não domina as regras ortográficas e não entende os enunciados das tarefas escolares. No ano passado, só foi aprovado pois teve aulas particulares e porque a família tinha uma certa influência na escola onde ele estudava.

O pai havia proposto um plano de “aprendizado conjunto" - estudava freqüentemente com o filho, mas o estudo converteu-se em um ponto de conflito, pois, para o pai, Otto não se esforçava muito, não aprimorava a produção escrita. Segundo o relato do pai, em um trabalho de mitologia, ele se propôs a ajudar o filho, e lhe disse para elaborar mais a escrita, e Otto respondeu: “- Mas isso é um trabalho de História e não de Português”. O pai ficou irritado e respondeu que se ele não entendia que era necessário escrever direito em todas as disciplinas, então ele era burro. Diante de um conflito, o pai parecia não se colocar em uma posição assimétrica, no lugar de adulto, mas sim, como um igual.

O pai tinha muitos planos em relação à nova convivência com o filho, mas aparentava ter uma expectativa exagerada em relação a essa experiência. Quando era contrariado por Otto, ficava desestabilizado. Queria que o filho aprendesse alemão, língua que ele dominava, pois havia estudado naquele país, contudo Otto não tinha interesse por essa língua; preferia aprender italiano, língua do país onde a mãe residia. Otto também fazia questão de mostrar ao pai que dominava o inglês, pois havia morado recentemente seis meses nos Estados Unidos.

Em suma, segundo o pai, havia se estabelecido uma competição intelectual. Apontei que ele parecia querer ser um professor para o filho, mas este solicitava um pai, simplesmente. Lembrei também que toda a relação afetiva necessita de tempo para se consolidar e sugeri que, naquele momento, seria importante controlar a ansiedade e manter-se mais sereno, afinal ele tinha mais experiência de vida.

Combinamos que eu iria realizar o diagnóstico psicopedagógico para dispor de mais dados para verificar que tipo de trabalho seria mais oportuno para Otto naquele momento. Para isso, marcamos uma nova entrevista para que eu levantasse mais informações sobre a história de Otto. 


\subsubsection{História do adolescente}

De acordo com o pai, o relacionamento dos pais de Otto foi marcado pela distância e por diversas separações. De início, habitavam em cidades diferentes. Quando decidiram ter um relacionamento conjugal, moraram juntos por certo tempo e mudaram para São Paulo, para o pai fazer mestrado, mas depois se separaram. Acabaram reatando o relacionamento e ela engravidou. Terminado o mestrado, voltaram para o Nordeste e foram morar na casa dos pais dele. Nessa ocasião, o pai concorreu a uma bolsa de estudos na Alemanha e foi aprovado.

Otto nasceu e depois de 4 meses o pai foi para a Alemanha. Quando o bebê tinha 8 meses, mãe e filho foram para aquele país encontrar o pai. Segundo o pai, o bebê não se adaptou à Alemanha. Teve uma doença que foi mal diagnosticada e isso gerou uma grande insegurança nos pais. O casal não ficou bem em um país estrangeiro e depois de oito meses a mãe decidiu voltar. O pai ficou naquele país e vinha para o Brasil a cada dois meses. Quando Otto tinha dois anos, a família voltou para a Alemanha e ficaram lá por um ano. Desta vez, Otto adaptou-se bem e chegou a freqüentar uma escola. A sensação do pai em relação a essa época é de que "tinham entrado nos eixos". No fim daquele ano, a bolsa não foi renovada e eles tiveram de retornar ao Brasil, bastante contrariados, pois estavam gostando daquela nova experiência.

Em relação aos dados de desenvolvimento de Otto relatados pelo pai, ele não apresentou nenhum atraso e nenhum sintoma em seu desenvolvimento físico e emocional. Quando era pequeno, tinha uma mochila que levava para todos os lugares e parecia representar um objeto transicional. ${ }^{44}$ Ela foi bastante utilizada na Alemanha (na segunda experiência) e no Brasil.

De volta para o Brasil, o casal teve certa dificuldade de se readaptar e começaram a ter muitos conflitos. O pai começou a carreira docente na universidade de sua cidade. Ficaram casados por mais dois anos e, de acordo com o relato do pai, numa viagem, estavam discutindo, acreditando que o filho dormia, mas Otto os surpreendeu e disse: “- é melhor vocês se separarem” . Decidiram separar-se. Segundo o pai, a esposa se queixava de que ele tinha uma relação “filial”" com ela e ele reconhece que, de fato, era muito imaturo.

O pai saiu de casa e a mãe tentou estabelecer-se profissionalmente por meio do comércio, mas não se deu bem. Teve dificuldades financeiras e decidiu alugar um quarto do

\footnotetext{
${ }^{44}$ Denominação que Donald Winnicott atribui ao uso que uma criança faz de um objeto que representa a mãe, na sua ausência.
} 
apartamento onde vivia para um amigo italiano. Logo eles iniciaram um namoro e, aos olhos do pai, ficou uma situação muito constrangedora.

No início da separação, o pai levava o filho para a escola e ficava com ele nos fins de semana. Porém, logo deixou ao critério do filho passear com ele ou não e Otto acabou escolhendo não mais sair com o pai. Não estabeleceram uma convivência sistemática. De acordo com o pai, na verdade, ele se posicionava como um irmão mais velho de Otto.

Depois de certo período, o namorado da mãe a convidou para ir para a Itália junto com ele e ela se sentiu "sem saída”, pois não tinha formação universitária e não conseguia estabelecer-se economicamente. A mãe decidiu partir para a Itália e o casal se divorciou. Ela colocou como exigência que o filho ficasse com os avós paternos. A mãe sempre mantivera uma boa convivência com os sogros. Segundo o pai, quando ela manifestou sua vontade, “todos acharam ótimo”, inclusive ele.

Otto tinha seis anos quando sua mãe partiu para o exterior. Segundo o pai, mãe e filho tinham uma relação muito boa, ela era amorosa e carinhosa. Pergunto como ele ficou com a partida da mãe e o pai reconhece que o filho sentiu muito a separação. Questiono se ele verbalizava algo ou se apresentou algum comportamento diferente, ou um sintoma qualquer. O pai disse que ele às vezes ficava quieto, no seu canto. Uma vez por ano, a mãe visitava Otto. Quando completou dez anos, ele passou a visitá-la na Itália com a mesma freqüência.

A relação de Otto com os avós era muito afetiva. Desde o nascimento, estabeleceram uma convivência muito intensa, inclusive moraram juntos em diversas etapas do casamento dos pais. O avô era muito apegado ao neto, e, segundo o pai, jamais fora tão próximo com os próprios filhos.

Segundo o pai, Otto foi criado "livremente”. Chamava os avós e os tios pelo nome, e sua educação parece ter sido bem permissiva. Na casa dos avós morava um filho temporão que foi como um irmão para ele.

Há seis anos o pai começou um relacionamento com a atual esposa e logo ela engravidou. Decidiram casar-se e tiveram dois filhos. Otto continuou morando com os avós.

Como os avós tinham a guarda de Otto, este se tornou herdeiro direto do avô e a família sabia que quando este viesse a falecer, o neto receberia uma pensão da universidade onde lecionora. Há quatro anos, o avô faleceu e isso foi muito difícil para todos. O pai não dá detalhes de como foi isso para Otto. A avó continuou cuidando de Otto. Há dois anos ela assumiu um posto de grande responsabilidade na universidade e ficou muito ocupada, 
deixando o neto solto demais. No ano seguinte da morte do avô, Otto foi visitar um dos tios nos Estados Unidos e ficou estudando lá por seis meses.

O pai ficou muito abalado com a morte do próprio pai, porém isso o impulsionou a desenvolver atividades mais lucrativas, a assumir uma postura mais madura, segundo ele. Veio para São Paulo com a mulher e os filhos pequenos.

Há um ano, a avó teve uma suspeita de câncer e esse fato teve um efeito importante, na perspectiva do pai de Otto, pois ele se perguntou: - como ficaria Otto? Interrogou-se sobre a situação peculiar do filho. Achou que havia chegado o momento de reaproximar-se de Otto e quis trazê-lo para São Paulo. Ao ser convidado a vir para cá e morar com o pai, ele disse que sua avó não iria concordar, mas esta concordou. Otto, então, aceitou a proposta.

Otto estava em São Paulo havia um mês. Tinha se adaptado bem à cidade e à nova escola. Locomovia-se pela cidade com autonomia. Já tinha estabelecido amizade com os colegas e passeava com eles nos fins de semana. Em relação aos estudos, como já foi afirmado, estava apresentando dificuldades.

Se a esfera social parecia estar caminhando bem, a esfera familiar aparentava ainda estar em adaptação. De acordo com o pai, o relacionamento com a madrasta parecia bom. Já em relação aos irmãos, Otto fazia brincadeiras um tanto quanto agressivas, no sentido de “aterrorizá-los”. O pai lhe dera uma bronca e havia dito que ele necessitava fazer uma terapia. Otto respondera que não tinha interesse nisso.

De fato, todos pareciam estar em adaptação à nova configuração familiar. Nem Otto estava sabendo como se colocar, tampouco o pai. Sabia ser pai dos filhos pequenos, mas estava encontrando dificuldades em relação ao "novo” filho adolescente. Estava inseguro em assumir o papel de pai de Otto, pois, como ele próprio confessara, até então, havia se posicionado como um irmão mais velho do filho. Mas parecia estar bem-intencionado; como já afirmamos, tinha vários planos. Havia estabelecido uma noite por semana para sair só com Otto, para se aproximarem e tentarem “aparar as arestas” que estavam surgindo no cotidiano.

Aqui podemos perceber a convergência de vários elementos conflitantes. Do lado do pai, notei a posição ambivalente em relação ao filho. No passado, ele delegara a função paterna a seu pai e, agora, embora seu discurso fosse de muita vontade de ser pai de Otto, ele ainda mostrava uma grande reverência ao pai morto e não parecia conseguir assumir tal posição em relação a esse filho. Assim como o adolescente tem de fazer o luto dos pais 
infantis para entrar no mundo dos adultos, de acordo com Arminda Aberastury e Maurício Knobel (1985), o pai de Otto resistia a “matar” seu pai.

Esse pai não conseguia assumir a diferença geracional em relação ao filho. Prova disso era a rivalidade fraterna entre o pai e Otto, tentando marcar quem sabe mais, ou quem pode mais. Outro dado nessa direção é a resistência a estabelecer limites claros para o filho, e a opção, pela via do diálogo, do psicologismo, de construir uma relação democrática entre pai e filho.

O pai muitas vezes conseguia fazer uma leitura das vulnerabilidades do filho, ao perceber que este queria competir intelectualmente com o pai, ou que ele tinha dificuldade de relacionamento com os irmãos (talvez por ciúmes); no entanto, essas percepções eram devolvidas de imediato ao filho, sem uma mediação, o que acabava criando uma atitude reativa de Otto. Essas pontuações do pai, em vez de servirem de elementos de reflexão para o filho, acabavam sendo rechaçadas e perdiam, assim, a possibilidade de serem representadas e elaboradas simbolicamente.

Do lado de Otto, havia a sua história de abandono. Fora abandonado pela mãe, quando esta partiu, e pelo pai, quando este delegou os pátrios poderes aos avós da criança. Talvez esses pais fossem, de fato, muito infantis e os pais simbólicos, desde o início, tenham sido os avós. O vínculo de Otto com estes parecia, de acordo com o pai, muito profundo. Talvez por isso ele os chamasse pelo nome, para não ter que dizer avô para alguém que é, de fato, o pai (inclusive pela lei).

Assim, havia, aqui, questões geracionais e de filiação simbólica; de um lado, um pai excessivamente ligado aos pais, e de outro, um filho, que pulou uma geração, ligando-se filialmente aos avós.

\subsubsection{História escolar ${ }^{45}$}

Otto começou a freqüentar a escola na Alemanha e adaptou-se bem, porém não obtive dados mais objetivos sobre essa etapa. Voltou para o Brasil com 4 anos e estudou em uma escola católica até a $3^{\mathrm{a}}$ série do Ensino fundamental. $\mathrm{Na} 4^{\mathrm{a}}$ série, foi para uma escola de ensino renovado, que estava sendo inaugurada. Freqüentou tal instituição por um ano e meio e

\footnotetext{
${ }^{45}$ Esses dados foram relatados por Otto, pois o pai não soube dar informações mais precisas sobre a escolaridade do filho. Os dados fornecidos pelo pai serão devidamente especificados.
} 
apresentou dificuldades, especialmente em matemática. Os avós decidiram que retornasse para a antiga escola no segundo semestre da $5^{\mathrm{a}}$ série.

Segundo o relato do pai, o avô dizia que Otto tinha dificuldades na operação de divisão e que isso se devia a um problema emocional. ${ }^{46}$ Otto teve dificuldades escolares, mas nada que preocupasse a família. Quando estava na 6 ${ }^{a}$ série do Ensino Fundamental, seu avô faleceu de câncer. Para Otto, foi nessa época que passou a ter dificuldades, ${ }^{47}$ pois "era seu avô que o botava para estudar”. Contudo, conseguiu ser promovido sem estudar muito.

Quando estava na $7^{\mathrm{a}}$ série, em julho, seu tio, ${ }^{48}$ que morava nos Estados Unidos e havia constituído uma família, o convidou para passar uma temporada em sua casa. Otto foi para lá e freqüentou a escola americana por seis meses. Levou um mês para adaptar-se. Teve aulas de inglês em uma classe específica para estrangeiros e assistiu às outras aulas com os colegas americanos. Otto achou as disciplinas fáceis, com exceção de Estatística, que, para ele, foi a única disciplina difícil. Segundo seu relato, na escola americana "tinha coisas muito práticas”, como carpintaria. Gostava também das aulas de Geografia e História.

Ao voltar para o Brasil, retornou para a escola católica para cursar a $8^{\text {a }}$ série e, segundo o pai, passou a apresentar problemas de comportamento. Quando perguntei ao pai que tipo de problemas ele apresentou, respondeu-me, com certo orgulho, que a família era “muito liberal, não “apostava” no autoritarismo e na subordinação”.

Na versão de Otto, os problemas surgiram porque o "nível de ensino era muito alto”. Vale lembrar que ele saiu do Brasil no $2^{\circ}$ semestre da $7^{\text {a }}$ série, tendo já apresentado dificuldades na série anterior, talvez pelo fato de ter perdido o avô, que era a sua referência para os estudos. Passou seis meses no exterior e voltou no início da $8^{\mathrm{a}}$ série, o que deve ter criado certa defasagem pedagógica. Diante das dificuldades, Otto passou a fazer brincadeiras nas aulas e a conversar com os colegas. De acordo com o adolescente, ele era um aluno "mau” e havia professores que não o queriam como aluno. Perguntei se ele imaginava que corria o risco de ser reprovado e ele respondeu que não, acreditava "que teria uma ajuda, pois sua família era conhecida lá”. Acabou sendo reprovado.

Havia certo mal-entendido na concepção familiar acerca da autoridade e do autoritarismo. De um lado, o pai acreditava que não era bom curvar-se ao autoritarismo,

\footnotetext{
${ }^{46}$ Vale marcar que o avô, que era adepto do discurso psicológico, não julgou que o neto necessitava fazer terapia.

${ }^{47} \mathrm{O}$ pai também acredita que as dificuldades na escola começaram após o falecimento do avô.

${ }^{48}$ Trata-se daquele tio temporão, com quem teve uma convivência muito intensa e que funcionava como um irmão para Otto, de acordo com o pai.
} 
porém, naquela situação escolar, parece que a questão consistia em aceitar a autoridade do professor, a assimetria entre aquele que ensina e aquele que aprende. Um detalhe: Otto comentou que o nível de ensino estava muito alto. Em outras palavras, o que talvez ele não estivesse aceitando era a diferença de saber, inerente à relação pedagógica. Por outro lado, contar com a família para resolver certos problemas escolares, usando de "influências", isto sim consiste em autoritarismo, em abuso de poder.

Otto foi cursar a $8^{\mathrm{a}}$ série na escola de ensino renovado onde já havia estudado; mais uma vez, teve dificuldades pedagógicas e a avó lhe sugeriu ter aulas particulares. Passou a ter essas aulas sistematicamente. "Foi levado nas costas", segundo o pai. De acordo com este, passou de ano graças às aulas particulares e por certa influência familiar. Apesar do discurso democrático da família, quando era necessário, recorria-se ao autoritarismo, tão arraigado às tradições coronelistas do nordeste.

Otto veio para São Paulo e estávamos no início de março. Ele já apresentava dificuldades escolares. Segundo o jovem, estava fazendo de tudo para ser bom aluno, isto é, estava "bonzinho", prestava atenção às aulas e realizava as tarefas escolares solicitadas pelos professores. Talvez o bonzinho seja o contrário de um aluno mau, como havia sido na $8^{\mathrm{a}}$ série, na escola religiosa.

\subsubsection{Diagnóstico Psicopedagógico}

Ficou combinado com o pai que o diagnóstico seria duas vezes por semana.

Em nosso primeiro contato, Otto se mostra bem receptivo, falante e espirituoso. Parece bem informado, comenta sobre política internacional, faz questão de mostrar que é “ilustrado”, crítico e gosta de polemizar.

Apesar de estar há um mês apenas em São Paulo, locomove-se com desenvoltura pela cidade, embora dentro de um círculo restrito. Usa o transporte público para vir ao consultório e para ir à casa dos amigos. Já domina bem a região em que circula.

Ao relatar sua experiência nos Estados Unidos, comenta que naquele país a escola se preocupa em “formar o cidadão”, dando uma ênfase mais prática ao ensino. Lá oferecem aulas de carpintaria, entre outras, ao passo que, no Brasil, há muitas disciplinas inúteis, em sua opinião. 
Esse tipo de opinião é comum entre os adolescentes, sobretudo daqueles que ainda não despertaram para o prazer do trabalho intelectual, da elaboração do pensamento que o Ensino Médio deveria proporcionar. Tal posicionamento coincide com o dos "novos liceanos”, adolescentes franceses advindos das classes trabalhadoras, que há dez ou quinze anos não tinham acesso aos estudos longos. Com a expansão do ensino secundário, passaram a freqüentá-lo. Para esses jovens, segundo Elisabeth Bautier e Jean-Yves Rochex (2001, p. 134), têm valor as disciplinas ou conteúdos que "são mais concretas e úteis”.

Otto é bem crítico: afirma que, no Brasil, todos têm de cursar a universidade - só assim alguém se torna "inteligente” (ou é reconhecido com tal). Diz, ainda, que iria queimar todo o material escolar depois de terminar a $3^{\mathrm{a}}$ série do Ensino Médio.

Proponho a ele a EOCA, a entrevista operatória centrada na aprendizagem, de Jorge Visca (1985). De início, Otto pega o Atlas, faz comentários sobre os conflitos no Oriente Médio, pergunta qual é a minha opinião sobre um determinado tema e diz qual é a sua, justificando sua posição com argumentos razoáveis. Pede que eu escolha um novo assunto para ele representar algo que aprendeu e eu digo que cabe a ele fazer isso.

Acaba optando por mostrar algo que aprendeu em matemática. Faz uma equação de $2^{\circ}$ grau. Cria a equação, mostra que sabe qual é a estratégia para resolvê-la, porém erra no cálculo. Na equação havia $20^{2}$, que corresponde a 400, mas em seu cálculo o resultado é 200. Erra na resolução da equação sem se aperceber desse fato.

A segunda aprendizagem diz respeito à Segunda Guerra Mundial. Faz uma narração sobre a batalha da Normandia. Peço que escreva o que me relatou e ele é bem sintético, faz um texto de forma bastante resumida. Depois de escrever, desculpa-se por sua letra e afirma, de forma categórica: "primeiro problema: não acentuo”. Diz que seu pai o corrige por isso. Da maneira como se expressa, não parece uma desculpa, mas, sim, um princípio, um ato de “desobediência civil”. Seu texto é cheio de rasuras (usou caneta), e ele também não diferencia “g” e “q”. Nem sempre usa a maiúscula para nomes próprios.

Parece que há, aí, uma tentativa de marcar sua subjetividade, de não se subordinar às solicitações externas. Uma hipótese é que isso represente uma generalização do princípio dito democrático da educação familiar. Vale lembrar que a família tem uma tradição acadêmica, e escrever mal se choca com a cultura familiar. Nesse caso, a insurgência seria em relação à família, e não propriamente à escola. 
A terceira aprendizagem a ser representada é um momento da história da Grécia Antiga, que se passou nas Guerras Médicas: “Os trezentos de Esparta”, uma batalha entre espartanos e persas. Otto relata que aprendeu nos Estados Unidos, sendo que, certos nomes, consegue referir-se apenas em inglês. Lembra-se de detalhes, como a época em que aconteceu esse evento e a denominação de certas localidades, como Helesponto. Porém confunde-se com o nome do rei, que diz ser Xerxes II e na verdade trata-se de Xerxes I. Desta vez, elaborou um texto mais longo, apresentando os mesmos erros do texto anterior, e ainda cometeu dois erros que representam marcas de oralidade: escreveu como se fala, como “mais”, no lugar da conjunção “mas” e “incurralado” em vez de “encurralado”.

O episódio relatado vem acompanhado de uma crítica ao que aprende na escola atual sobre a Grécia. Diz que o conteúdo é muito superficial. Vale assinalar que o tema cujo trabalho ele apresentou dificuldade para realizar, de acordo com o pai, era sobre mitologia. Apresenta uma postura “ilustrada” para mim, mas não consegue sustentar essa atitude quando se trata de realizar um trabalho escolar.

O conteúdo das duas últimas representações de aprendizagem foi uma batalha. Há certa obsessão por esse tema e pela memorização de informações. Notei uma marca de exibicionismo em Otto, que seria importante observar, para verificar que fim ele atribuía ao conhecimento - fruição cultural ou competição intelectual.

No Par Educativo, desenho de uma situação de aprendizagem, ele fez um desenho bem pequeno, representando uma lousa, com um professor representado na forma “de

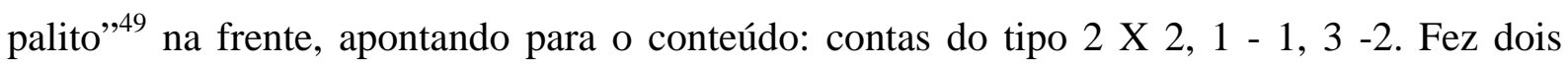
alunos: um sentado e outro de pé. Não desenhou mais nada. Executou de forma bem rápida e não elaborou de maneira alguma o desenho. Quando perguntei de que situação se tratava, ele disse que era uma classe de $1^{\text {a }}$ série e os alunos estavam aprendendo matemática. Perguntei o que eles estavam achando da aula - nada. E o que os alunos achavam do conteúdo que estava sendo ensinado? Ele disse que era "normal”, nem fácil e nem difícil.

Chamou a atenção o interesse e a disposição manifestados por Otto na primeira atividade e nesta, na qual ele investiu minimamente, o que ficou evidenciado pelo tempo exíguo empregado na sua produção. Pouco elaborou o desenho e não o utilizou para exibir seus conhecimentos, como na EOCA. Pelo contrário, mostrou um desenho muito rudimentar,

\footnotetext{
${ }^{49}$ Maneira bem primitiva para representar a figura humana.
} 
com pessoas desprovidas de traços secundários. ${ }^{50} \mathrm{O}$ professor tem as mãos que apontam para a lousa, e os alunos não dispõem de mãos. As mãos, de forma geral, representam os principais meios de apropriação das coisas, de transformação, além da mente. Podemos depreender, então, que os alunos estão em uma situação passiva. Ainda em relação às pessoas representadas, todos são do mesmo tamanho e são quase iguais. Não há marcas da diferença entre o adulto e as crianças. A única diferença se faz pelo negativo: o aluno sentado é meio deformado, tem pernas excessivamente longas e parece colado à cadeira. Está impossibilitado de se movimentar. Além disso, seu rosto é vazio, sem qualquer elemento; diferente do adulto, cujo rosto contém os elementos básicos (olhos e boca).

A classe de $1^{\text {a }}$ série parece muito infantil para ser escolhida por um adolescente, que inclusive critica o conteúdo superficial que aprende na escola. Não há também nenhuma expressão, mal se vê a cara de cada um, visto que o tamanho é bastante reduzido. A situação de aprendizagem parece algo destituído de sentido e de interesse, enfim algo banal. Os alunos parecem apáticos. Nesse desenho, a relação professor-aluno não evidencia nenhum elemento positivo. O professor parece olhar para o aluno que está de pé, e este, por sua vez, olha para a lousa, mas não há indícios de uma troca entre ambos.

Como já foi afirmado, a única diferença entre o adulto e os alunos é que o professor tem mãos e os alunos, não. Coincidentemente, a mão do professor que é mais destacada é aquela que aponta para o conteúdo da lousa. Podemos depreender que a posse de conhecimento é, de forma bem sutil, valorizada.

Nas provas operatórias de pensamento formal sistematizadas por Lino de Macedo (1983), Otto ficou bastante entusiasmado, mostrando, inicialmente, que gostava de ser desafiado intelectualmente. Na prova de permutação, em que o sujeito deve primeiro fazer uma predição ${ }^{51}$ em face do seguinte desafio: “de quantos modos é possível permutar três fichas de cores diferentes?”, ele acertou sua predição e depois pedi que executasse a permutação, a fim de que eu pudesse observar o seu método de trabalho. Ele foi bemsucedido. Porém, quando o número de fichas começou a aumentar, ele se desestabilizou, passou a predizer de forma impulsiva, sem organizar o pensamento. O mesmo ocorreu na execução. Não criava um método regular, no qual pudesse controlar as variáveis. Ficou bem

\footnotetext{
${ }^{50}$ Elementos que marcam o sexo na figura humana, como o cabelo comprido, para indicar que é mulher, ou duas pequenas curvas no tronco, para representar os seios, ou um bigode, para indicar que é homem, etc.

${ }^{51}$ Ou seja, deve resolver um desafio mentalmente, sem fazer o uso da experimentação.
} 
incomodado com o desafio de ter de predizer e notei, nas outras provas, que necessitava da atividade de experimentação.

Para ele, o ato de pensar diante daqueles desafios deveria ser acompanhado do auxílio do material concreto. Isso denota certo apego aos objetos, o que é próprio do período das operações concretas, pois o sujeito opera de forma a estabelecer relações sempre com os objetos e suas propriedades. Já no período de operações formais, os objetos não são mais considerados. Mesmo que essa prova faça uso de material concreto, o tipo de relação que subjaz sua resolução implica um sistema de lógica proposicional.

Na prova de conservação de volume, mostro dois frascos iguais, com o mesmo nível de água e duas bolas de massa de modelar de mesma quantidade. O objetivo é verificar se o adolescente percebe que dois objetos, com a mesma quantidade e concentração de matéria, ocupam a mesma dimensão de espaço, não importando suas configurações (ex: uma salsicha ou uma bola). Otto fez as predições, mas, em seguida, recorreu à experimentação para comprovar seu acerto. Nessa prova não há a necessidade da experimentação, mas para Otto isso era importante. A necessidade de recorrer à execução denota um apego ao referencial concreto e, portanto, uma dificuldade de lidar com proposições verbais.

Observo também que Otto tem dificuldade de reconhecer que não sabe algo, Geralmente, dá uma justificativa com uma forma científica, mas que contradiz tudo o que afirmou anteriormente. Quando foi questionado se uma bola e uma salsicha de mesma massa e peso fossem jogados em frascos de água, como subiria o nível de cada frasco, ele respondeu que ainda não havia estudado isso em Física. Em vez de dizer que não sabia, optou por aquela resposta. Ora, sabemos que a conservação de objetos não é ensinada na escola. Ela advém da necessidade da inteligência organizar o universo em forma de objetos permanentes. O sujeito constrói tais noções por meio da interação com o ambiente, no sentido de organizar o universo físico.

Na segunda transformação, perguntei se uma bola inteira e a outra bola, fragmentada em 8 pedaços, subiriam o mesmo nível, se fossem jogadas nos copos. Ele respondeu que isso era parecido com a "questão do peso e do chumbo”. Trata-se daquela conhecida questão que se apresenta: “o que pesa mais: um quilo de algodão ou um quilo de chumbo ?” É uma pergunta com a intenção de confundir o outro. Mais uma vez, ele não tinha a resposta e se desviou da pergunta. Estava inseguro para responder, mas quis, para compensar, dizer algo “inteligente”. Vale lembrar que não estávamos discutindo sobre a igualdade do peso, mas se o volume era igual. 
Observei, nessas provas e em outras situações, que Otto, além de necessitar de uma referência concreta para organizar seu pensamento, estabelecia um método de trabalho sem o rigor necessário para chegar a uma solução coerente.

Isso ficou particularmente claro no jogo Shape by Shape, ${ }^{52}$ que é uma espécie de Tangram. Como o Tangram, suas peças são geométricas e há infinitas possibilidades de combiná-las, com o fim de reproduzir diversos modelos pré-estabelecidos. A diferença é que este é acompanhado de uma moldura e, no final, fica parecendo um quadro. Esse jogo explora as relações infra-lógicas e exige do sujeito grande persistência e concentração para ser resolvido.

Otto apresentou grande dificuldade para montar a figura de um dado modelo. Não explorava todas as possibilidades de rotação das peças. Experimentava de um lado e não tentava dos outros lados, utilizando uma estratégia de ensaio e erro. Dizia ser impossível. Em certo momento, mostrei que uma das peças não havia sido experimentada em todas as posições e ele conseguiu sair do impasse. Conseguiu completar a figura, mas, na hora de montar a moldura, ficou bem irritado, pois não conseguia finalizar. Tentei resolver parte dela, para depois deixá-lo terminar e fiquei explorando uma peça de cada vez, colocando em todas as posições possíveis. Ele comentou que até eu não conseguia executar o modelo. Falei que ainda não havia tentado todas as possibilidades, e isso levava algum tempo. Por fim, consegui. Mas observei que ele ficou um pouco decepcionado quando cheguei ao fim. Notei também que ficou exultante com a minha demora.

Observei, ao longo das atividades do diagnóstico, que havia uma grande discrepância na postura de Otto diante de desafios verbais e desafios lógico-matemáticos. Nos primeiros, ficava bem confiante, e nos desafios lógicos, em que tinha que elaborar uma estratégia coerente e controlar todo o processo, ficava inseguro. Certo dia fiz um comentário a esse respeito e ele disse que era tímido e não gostava de errar. Apontei que isso não me parecia timidez, mas rigidez, pois sua estratégia me parecia um pouco simples: ele tentava resolver o desafio de uma maneira apenas e não se abria para outras possibilidades. Para ele, só havia uma forma de resolver as situações-problema, caso contrário, era “impossível” resolver. Estava me referindo à sua rigidez de pensamento.

Ao longo do diagnóstico, ficamos mais próximos, e, certa vez, Otto falou: “- Meu pai disse para te contar que fui mandado para fora da sala de aula”. Questionei o que havia

\footnotetext{
${ }^{52}$ Este jogo é da Binary Arts, empresa americana conhecida aqui pelo jogo Rush Hour.
} 
acontecido e ele me perguntou se era para ele me contar "essas coisas". Talvez pensasse que falar sobre determinadas coisas ultrapassaria o limite de uma psicopedagogia. Primeiramente, falei que era ele que decidia o que falaria comigo, ele não precisava “dar recado do seu pai”. Poderia me falar o que quisesse, desde que achasse que fosse oportuno compartilhar suas coisas comigo. Procurei explicitar que eu procuro fazer o sujeito pensar sobre as coisas que faz e que acabam prejudicando a aprendizagem. Falei que poderíamos ver até que ponto eu poderia ajudá-lo, pois muitas vezes faz-se necessário um outro tipo de trabalho, uma psicoterapia. Ele disse que não queria fazer isso.

Então ele contou que desafiou o professor de Português que, segundo seu relato, era gay e estava com "TPM". 53 Comentei que ele parecia estar se expondo demais e criando uma situação desfavorável para si. Ele disse que tinha 16 anos e que seus colegas eram mais novos do que ele e temiam os professores, mas ele não. Argumentei que as pessoas mais velhas costumam ter mais experiência, nesse caso, se ele era mais experiente, deveria usar esse conhecimento a seu favor e não contra si próprio. Otto falou também que sua professora de História “não sabia nada”. Pontuei que era evidente que um professor sabe muito mais que os alunos, pois tem uma formação profunda sobre uma disciplina, que lhe autoriza a ensiná-la aos outros. Comentei que, se aquela professora havia sido contratada para isso, era porque ela havia participado de uma seleção e tinha sido aprovada por seu conhecimento para trabalhar naquela instituição.

Apontei que ele parecia não usufruir dos conhecimentos que havia adquirido. Utilizando o seu repertório, observei que ele se interessava muito por guerras, como havia demonstrado na atividade de representação de aprendizagem (EOCA $\left.{ }^{54}\right)$. Lembrei que uma coisa fundamental nas guerras é a estratégia - ela pode levar um exército à vitória ou à derrota, mas para isso era necessário conhecer o terreno e as variáveis que constituem uma determinada situação. Mostrei que ele não estava sendo nem um pouco estratégico. E, o pior, estava tornando os professores, indivíduos que poderiam ajudá-lo e ensinar-lhe muitas coisas, seus inimigos.

A estratégia faz parte das lógicas a que todos recorrem no ambiente escolar, no contexto da desinstitucionalização, de acordo com Dubet e Martuccelli (1996). No caso da estratégia, esta consiste em construir uma racionalidade instrumental para garantir o lugar de

\footnotetext{
53 Tensão pré-menstrual.

${ }^{54}$ EOCA - Entrevista operatória centrada na aprendizagem, proposta por Jorge Visca (1985), descrita anteriormente.
} 
aluno e angariar as melhores posições. Apesar de ela revelar um aspecto interesseiro, ela implica o reconhecimento das diferenças: o professor sabe mais, portanto é ele que avalia o aluno. Ela também implica certa humildade, perda da onipotência, reconhecimento da própria ignorância. Era isso que Otto não conseguia admitir.

Também conversamos sobre sua situação em São Paulo. Perguntei se estava sentindo falta de sua avó e de sua cidade natal. Ele respondeu: “-Me acostumei a não ter saudades. Desde os seis anos minha mãe viajou e depois meu pai também”. Se não desenvolveu estratégias para se orientar na escola, em relação aos laços parentais, ele havia desenvolvido uma estratégia de sobrevivência diante do sofrimento.

Ao enfrentar os professores, parecia que Otto havia desistido de ser o aluno “bonzinho”. Estava agora mostrando o seu lado “mau”, que já havia manifestado quando retornou ao Brasil, ao iniciar a $8^{\text {a }}$ série. Isso parecia recorrente - apresenta dificuldade para acompanhar o conteúdo escolar e, em vez de mostrar que não sabe e pedir ajuda, ele desafia a autoridade do professor.

Certa ocasião, quando retomamos o tema da rigidez , Otto disse: “- Eu tenho que fazer tudo bem feito, senão eu não faço”. Perguntei se era "tudo ou nada” e ele disse que era “mais ou menos”. Ora, creio que este "tudo ou nada” se aplicava bem àquela situação escolar. Se ele estava com defasagens pedagógicas e sentia dificuldade para acompanhar o conteúdo escolar, então ele saía da lógica do trabalho escolar e partia para o ataque aos professores. Já que não podia fazer as tarefas escolares bem feitas, não fazia nada.

Tal atitude denotava o que David Elkind (1975, p. 69) denomina presunção cognitiva, própria ao egocentrismo do adolescente, que acredita na sua superioridade em relação aos adultos. Ao experimentar alguns vôos intelectuais com certos instrumentais do pensamento formal, muitos jovens ficam convictos da sua competência intelectual e assumem uma postura um pouco arrogante em relação aos outros, sobretudo diante daqueles que são reconhecidos por seu saber.

De qualquer forma, apesar da presunção cognitiva, havia, também, a ambição intelectual de Otto. Ele desejava ser admirado por seu saber, e por isso cultivava certo “enciclopedismo”, porém não conseguia sustentar tal posição, pois logo as dificuldades pedagógicas desmascaravam tal pose. A fim de não reconhecer suas dificuldades, entrava em competição com aqueles que ele acreditava que tinham posse do saber. Procurava tirar a legitimidade do saber dos professores. 
De fato, ele parecia entrar em uma competição intelectual com os adultos, inclusive com seu pai, que era professor universitário. Um exemplo da ambição de Otto é que, em uma ocasião, lhe pedi para dar o sinônimo de algumas palavras, e na palavra "brilhante”, ele disse: “esperto, aquele que se sobressai em relação aos outros”. Acredito que era esse o seu desejo ser reconhecido como alguém que sabe, que é competente.

Propus a ele duas atividades de Leitura e Escrita. A primeira era uma atividade de compreensão de texto, extraída de um livro para adolescentes. ${ }^{55}$ Mostrei a ele primeiramente o texto “A era da imagem” e disse que haveria questões de compreensão da leitura para serem respondidas posteriormente. Otto iniciou a leitura e logo solicitou que eu lhe mostrasse as questões, que estavam em uma folha à parte e eu lhe dei o papel. Interrompeu a leitura do texto e passou a ler as questões de compreensão antes do próprio texto. Queria fazer as duas coisas simultaneamente. Executava a tarefa e falava alto, me utilizando como um Ego auxiliar $^{56}$ - “esse assunto (relativo a determinada questão) eu já passei e nem notei”. De fato, as coisas lhe escapavam, uma vez que não realizava cada etapa em seu tempo. Com essa atitude, notei que Otto apresentava uma postura mais "tarefeira” em relação ao trabalho escolar, o que denota certa infantilidade, pois, no Ensino Médio, mais vale desconstruir um texto e seus pressupostos para melhor compreendê-lo, do que responder imediatamente às questões.

A primeira resposta foi telegráfica. A questão era sobre que meio de comunicação poderia concorrer com a televisão no futuro. Ele respondeu simplesmente: “internet”. A segunda questão, em que tinha de apontar as vantagens e desvantagens da televisão, ele respondeu como desvantagem: “a televisão está em todos os lugares, em todas as horas, é relativamente barata e é fácil de ligar”. Ora, isso não parecia representar uma desvantagem. No final, apontei isso e ele completou: “...o que afasta as pessoas dos livros”.

Sua produção em Leitura e Escrita denota um déficit acomodativo, na perspectiva piagetiana; ele não usa regras gramaticais e tampouco se preocupa em formular respostas que sejam compreensíveis pelo leitor. Não elabora sua produção e, nessa atividade, não mostra sua opinião sobre o tema. Apontei isso para Otto e então ele expôs sua posição em relação à

\footnotetext{
${ }^{55}$ ALLIENDE, F.; CONDEMARIN, M.; CHADWICK, M.; MILIC, N. Compreensão de Leitura 3. Fichas para o desenvolvimento da compreensão da leitura com adolescentes. Campinas: Editorial Psy II, 1994.

${ }^{56}$ De acordo com E. Dorin (1978), o Ego auxiliar, no Psicodrama, corresponde a uma pessoa que substitui outra no desempenho de um papel e que assim colabora com o sujeito, no sentido de ajuda-lo a comprrender uma determinada situação. No caso da psicopedagogia, ajudamos o sujeito a organizar seu pensamento ou sua ação. Isto é, alguém de fora o auxilia a dar conta de uma tarefa que oferece desafios para a sua consecução. Não pensamos pelo sujeito, mas com o sujeito, damos modelos de como pensar, de como proceder diante de uma situação.
} 
televisão, indo contra o autor. Para o jovem, a televisão era mais instrutiva do que um livro, pois, se tratasse de um canal educativo, ele transmitiria imagens e isso seria muito mais eficiente para a aprendizagem do que a leitura. Quando contra-argumentei, ele mostrou-se defensivo, não quis trocar idéias, fechou-se em uma posição e ficou refratário aos meus argumentos.

A segunda atividade era uma pequena dissertação, com base em um artigo de jornal, "Fé na corrida", ${ }^{57}$ que fala sobre o esporte da corrida e o sentido que as pessoas atribuem a ele. Nesse texto era abordado o aspecto desportivo dos corredores profissionais, mas o aspecto mais enfatizado era o da corrida como hobby. Discutia-se a corrida como desafio pessoal, a dedicação a uma atividade mais introspectiva, que leva à consciência dos próprios limites. Isso não foi significativo para ele.

Em relação à leitura, foi possível constatar que Otto ainda não dispunha de estratégias metacognitivas de leitura, que consistem em identificar as informações que são mais relevantes, direcionar a atenção para as áreas realmente importantes e realizar o controle da leitura para verificar se está realizando ou não uma boa compreensão (KATO, 1985). Ficou claro que fez uma leitura em um nível superficial, não se aprofundando em questões que estavam apontadas de forma indireta, nas entrelinhas, e não percebeu isso.

A dissertação costuma ser um texto polifônico, segundo Bautier e Rochex (2001), pois é constituído de muitas vozes, referências. Neste caso, tratava-se das posições do jornalista, dos personagens investigados, da mídia e do próprio Otto. Para realizar esse tipo de texto, há que estabelecer um diálogo entre as diferentes vozes e estabelecer um registro que não seja nem o da opinião e nem o da "verdade absoluta" dos outros referenciais. Mais importante é o distanciamento para discernir um ponto de equilíbrio entre as diversas posições.

Em relação à escrita, Otto ficou preocupado com o número de linhas a escrever e com a necessidade de colocar muitas informações. Falou inclusive sobre a corrida de São Silvestre e as Olimpíadas. Trata-se daquilo que os autores comentam sobre construções textuais que consistem na sucessão de idéias, sem uma devida articulação, às vezes justapostas por relações de contigüidade, mais do que relações de sentido. Para alguns jovens, a mera enunciação de idéias, sem uma análise apropriada, parece ter uma força argumentativa.

\footnotetext{
${ }^{57}$ Publicado no Suplemento Equilíbrio, Folha de São Paulo, 21/03/02.
} 
Deu também vazão a sua opinião, afirmando que “o governo deveria dar mais valor aos corredores e proporcionar mais competições”, sem articular essas idéias aos demais referenciais. Ficou claro que Otto apresenta uma dificuldade de descentração. Para ler e escrever, e mesmo para qualquer situação de aprendizagem, é necessário fazer uma “trégua”, um momento de suspensão em relação às próprias convicções para expô-las ao exame e ao confronto em relação às demais referências, o que esse adolescente absolutamente não faz. $\mathrm{O}$ termo trégua se ajusta ao cenário dramático que a situação de aprendizagem representa para ele - um confronto em que haverá o derrotado e o vencido - mas Otto não percebe que desse confronto o sujeito pode sair mais enriquecido em seu repertório e como ser humano.

Vale assinalar que Otto manteve uma postura "pendular” durante o diagnóstico. Vinha duas vezes por semana e por diversas vezes quis desmarcar a segunda sessão da semana, que era na quinta-feira. Tivemos de conversar em várias oportunidades sobre isso; combinei que só desmarcava a sessão com antecedência e por um motivo muito justo.

\subsubsection{Conclusão diagnóstica}

Otto parece não ter inscrito os pais reais como referências para a sua filiação simbólica. Os pais simbólicos foram os avós paternos. Estabelece com o pai verdadeiro uma relação fraternal, entrando freqüentemente em rivalidade com este.

Segundo o adolescente, era o avô que o fazia estudar. Ele só se colocava na lógica do trabalho escolar com aquela figura. Sem o avô presente, ele não entra no jogo escolar. É como se não tivesse elaborado essa perda. Não consegue encontrar outra pessoa que tenha legitimidade para ocupar o lugar daquele que o fazia estudar. Tampouco conquistou uma autonomia, no sentido de poder dispensar esse mediador. Para ele, a relação com o saber é exclusiva. Ou o saber fica com um sujeito, ou fica com o outro, não havendo nem a situação da troca e tampouco a situação de compartilhar um saber.

Apresenta uma modalidade de aprendizagem hiperassimilatória. Como não troca, não dialoga com o que vem do exterior; portanto, não se submete às normas externas. Necessita de um adulto para mostrar que certas coisas simples são importantes, como escrever diferentemente o "g” do “q” , segundo a convenção. Parece clamar por um adulto que se coloque do lado da norma e o ajude a sustentar a lógica do trabalho escolar. 
No que diz respeito ao raciocínio lógico-matemático, seu desenvolvimento cognitivo apresenta certa defasagem, pois necessita ainda da referência concreta para solucionar certos desafios de ordem lógica. Não dispõe ainda de estratégias para lidar com proposições formais. Tampouco apresenta procedimentos de controle da própria produção cognitiva.

Muitas vezes o objeto de conhecimento parece configurar-se como objeto de pulsão - Otto quer dominar o objeto a qualquer preço, como se tratasse de uma situação de vida ou morte. No entanto, não faz uso de estratégias racionais para procurar controlar o objeto, como no trabalho sobre mitologia, ou com o Shape by shape.

Não tolera a situação de assimetria na aprendizagem - para ele, ser diferente, ter menos (saber) é algo desconfortável, desestabilizador. Não aceita não saber, por isso compete com o outro, no sentido de apagar essa diferença. Quando não sabe algo, recorre a subterfúgios para não se expor e, quando erra, ou se sente injustiçado, ou afirma que aquilo não é importante para ele (como as regras de ortografia e outras normas do código escrito).

Otto recorre à racionalização, busca explicações lógicas para suas dificuldades, falhas e para as situações em que se coloca em conflito.

Do ponto de vista emocional, há um percurso que Otto ainda parece não haver feito: o luto pela morte do avô, a raiva por ter sido abandonado pela mãe e também pela ambivalência do pai. De acordo com o relato do pai, ele não expressou a dor e a indignação em relação às figuras parentais.

Aos poucos, ele teve uma boa interação comigo e começou a falar um pouco sobre si. Encarou positivamente o diagnóstico e se pôs a refletir sobre sua forma de pensar e de agir em relação às situações de aprendizagem. Necessita de alguém que faça a síntese de algumas situações, como a competição, e o leve a pensar sobre isso e a se posicionar a esse respeito.

Mais uma vez deparo com um problema de aprendizagem que não se trata de um sintoma, no sentido de uma metaforização de uma operação lógica, nos moldes de Sara Paín (1996), mas de uma inteligência que sofria uma diminuição de sua função, nas palavras de Parente (2000, p. 66). Aqui fica claro que se trata de uma questão emocional, no entanto Otto já foi reprovado uma vez e está desprovido de recursos para interagir com os conteúdos ministrados no Ensino Médio. Apesar da grande ambição intelectual, todas as vezes em que é colocado diante de um desafio mental, em vez de lidar com um conflito cognitivo, este se converte em conflito subjetivo. A situação de aprendizagem adquiriu uma feição dramática, 
simbólica, no dizer de Sara Paín (1996), e, a cada nova decepção, Otto tem reagido negativamente, criando situações embaraçosas para ele.

Discuto o caso em supervisão e concluo que, por ora, Otto pode beneficiar-se de uma psicopedagogia para favorecer a ampliação de sua estrutura cognitiva, propiciar as acomodações, no sentido piagetiano, para que possa integrar seu interesse pela cultura e a necessária sistematização do conhecimento. O tratamento psicopedagógico pode converter-se em uma situação na qual, apesar da assimetria, pode haver troca, cooperação e construção de conhecimento.

O atendimento pode viabilizar que Otto vá se aproximando, gradativamente, de certas questões que tem evitado pensar e sentir. A intenção é que possa formular, gradativamente, o pedido de uma psicoterapia ou psicanálise, para lidar com questões que ficaram pendentes em sua história.

O atendimento deve ser acompanhado de entrevistas com o pai, fazendo pontuações e orientações que o levem a marcar a diferença geracional em relação ao filho e assumir a autoridade que lhe cabe.

\subsubsection{Devolutiva do diagnóstico}

Retomei o diagnóstico com o pai, falando da postura de Otto, da forma como se comprometeu com o trabalho, mostrando, de um lado, interesse em ser ajudado e, de outro, uma dificuldade em manter o compromisso. Várias vezes ele quis desmarcar a sessão de quinta-feira e uma vez chegou a faltar. Ficara combinado que, em caso de falta, ele avisaria o pai, porém constatei que ele não o avisou.

Conversamos então sobre os dois pólos de Otto - o da onipotência, daquele que sabe e que parece ser auto-suficiente, e o pólo da impotência, que tem dificuldade de manter o esforço para atingir um objetivo e que duvida de si. Quando está neste pólo, fica um pouco fóbico e foge dos desafios.

O pai reconhece que está difícil Otto manter o papel de aluno durante toda a semana. Quando chega quinta-feira, já dirige seus interesses para a vida social e deixa a esfera escolar de lado. 
Falo sobre sua modalidade hiperassimilatória ${ }^{58}$ e a dificuldade de acomodar-se às demandas externas, de submeter-se aos objetos de conhecimento, notadamente às convenções da língua escrita. Dei o exemplo da grafia semelhante para letras diferentes e da necessidade de ter um Ego auxiliar, alguém que o ajude a monitorar sua produção.

A partir de fatos que ocorreram durante o diagnóstico, aponto que Otto parece apresentar um problema de aprendizagem e que seu pensamento ainda está muito ancorado no concreto, quando poderia estar se libertando dele, lidando com proposições formais. Diante de tal quadro, afirmo que ele necessita de um atendimento psicopedagógico, embora houvesse questões, como a competição, que me parecia ter relação com o pai e, portanto seria algo da ordem emocional.

Diante de certos elementos que me parecem relacionados à dinâmica afetiva, esclareço que eu aponto a questão para o sujeito, procuro identificar com o jovem em que situações isso se coloca, com quem, mas o porquê fica ao critério do sujeito se interrogar. O trabalho psicopedagógico procura sensibilizar o adolescente para suas questões, para que possa, gradativamente, ter o desejo de fazer uma análise ou uma psicoterapia. O pai responde que ele não quer fazer isso agora, e que tem certa resistência porque todos na família paterna fazem análise.

O pai conta que Otto começou a fumar maconha. O pai admite que também já fumou maconha, que eventualmente ainda fuma e Otto sabe disso. Um irmão do pai é usuário contumaz de maconha e é uma pessoa bem problemática, segundo seu relato. Ele teme que o filho se torne também um usuário e acha que Otto tem um perfil para isso.

De acordo com o pai, o filho cometeu uma “distração” e o pai acabou descobrindo que ele fuma. Pelo jeito como foi descrito, Otto parece ter feito isso intencionalmente, no sentido de que o pai se posicionasse a esse respeito. De fato, ele não soube o que lhe dizer. Na verdade, estava ávido por “dicas” de como abordar o assunto com o filho. Ao ser descoberto pelo pai, Otto argumentou que sua concentração melhorava quando fumava maconha e o pai não soube contra-argumentar.

O pai não havia percebido que a distração de Otto tinha sido intencional, isto é, pela forma como ele relatou, é evidente que o filho queria que o pai tivesse ciência disso. E talvez

\footnotetext{
${ }^{58}$ Como já foi afirmado no caso anterior, trata-se de uma formulação de Sara Paín (1985), que diz respeito à modalidade de aprendizagem em que o sujeito nega curvar-se aos objetos de conhecimento, querendo sempre submetê-los às suas necessidades e desejos.
} 
esperasse por uma reação mais enfática. No entanto, o pai foi hesitante e não soube contestar a afirmação de que a maconha é boa para a concentração.

Ora, muitos estudos afirmam que a maconha funciona como um ansiolítico, causando relaxamento, bem-estar e, por vezes, euforia. Esse não me parece um estado propício ao estudo. Segundo os neurocientistas Renato Malcher-Lopes e Sidarta Ribeiro (2008, p. 43), a ação da maconha se dá principalmente no funcionamento da memória de curto prazo. ${ }^{59}$ Seu uso provoca alterações na atenção, no processamento de informação, na solução de problemas, no pensamento abstrato e no cálculo matemático. Em suma, a atenção e a cognição ficam bastante prejudicadas quando o indivíduo se encontra sob o efeito dessa droga.

Independentemente de qualquer opinião sobre a maconha, apontei que uma coisa era fumar eventualmente, em situações de "lazer”, como parecia ser o caso do pai. Ao contrário, um adolescente geralmente está em busca de novas experiências, não tem a capacidade de se controlar como o adulto, e, no caso de encontrar dificuldades na vida real, é difícil que consiga usar da moderação para utilizar a maconha.

Dou a minha opinião a esse respeito - fumar maconha prejudica os estudos e reforça um comportamento de fuga, que poderia "fechar" esse círculo que Otto estava criando: dificuldade pedagógica, desatenção em classe, desafio aos professores. Apontei que, se ele temia que Otto se tornasse um usuário, deveria mostrar isso para o jovem e fundamentar sua opinião. Primeiro, deveria se colocar como um responsável pelo filho, afirmando que se preocupava com o fato de que Otto não conseguisse levar a sério os estudos, e eles tinham exemplos na família de que isso poderia se tornar prejudicial para o desenvolvimento do jovem. Em segundo lugar, poderia procurar pesquisas científicas que evidenciassem o prejuízo do uso da maconha para a aprendizagem e discuti-la com Otto.

Por fim, reforcei que, naquele momento, o pai não poderia ser ambivalente em relação à maconha, tampouco ao exercício da autoridade, que agora, mais do que nunca, cabia a ele assumir. Mostrei que Otto clamava por isso.

\footnotetext{
${ }^{59}$ No modelo da Teoria do Processamento de Informação, proposta pela Psicologia Cognitivista, de acordo com Evely Boruchovitch (1999), a memória de curto prazo, ou memória operacional, é a sede em que processos executivos controlam a atenção, manipulam a informação e a organizam de forma que esta possa ser recuperada sempre que necessário. Segundo esse modelo, a memória de curto prazo cumpre um papel fundamental para a aprendizagem. Remetemos também o leitor a Saul Cypel (s/d):

www.neurodesenvolvimento.com.br/artigos/artigo_opapeldasfuncoes.pdf.
} 
Combinamos iniciar o atendimento psicopedagógico e mantermos um contato constante, inclusive pelo telefone, no sentido de ajudar Otto a manter-se dentro da lógica do trabalho escolar e não buscar formas de fuga em relação a essa tarefa.

Na devolutiva ao Otto, falei que me chamou a atenção como muitas estratégias que elaborava mentalmente, ou raciocínios que utilizava para resolver uma situação-problema, ao final, sempre necessitavam de um teste, para ele concretizar e verificar se estava certo. Por um lado, isso me parecia bom, pois isso fazia parte do método científico, porém havia situações em que isso não era necessário. Perguntei se ele ficava inseguro quanto aos seus raciocínios e ele disse que sim.

Também notei que muitas vezes suas estratégias me pareciam um pouco limitadas e, se elas não davam certo, ele acabava desistindo, em vez de tentar ampliá-las. Usei alguns exemplos, como no jogo Shape by shape.

Comentei que ele me pareceu muito esforçado em algumas situações, como ao representar as coisas que aprendeu, mostrando que sabe coisas muito interessantes, como a Batalha dos Trezentos de Esparta, porém, em outras situações, como as atividades de leitura e escrita, me pareceu que ele não procurou elaborar sua produção.

Otto disse que os professores eram exigentes demais em relação à escrita. Comentei que solicitar que o aluno diferencie as letras, acentue as palavras, use maiúscula para nomes próprios e início de frase, não me parecia um exagero; pelo contrário, era o mínimo que um aluno do Ensino Médio devia fazer. Acrescentei que muitas vezes ele não era muito claro quando se expressava pela escrita, como na resposta das desvantagens da televisão, em que ele só falou sobre as vantagens.

Procurei realçar seus pontos positivos e falei que sua expressão verbal era muito boa, e eu havia aprendido diversas coisas com ele, sobre guerras e outros assuntos. No entanto, notei que ele parecia não gostar de dialogar para trocar e, eventualmente, rever seus argumentos. Comentei que havíamos discutido sobre inteligência artificial e, em certo momento, em que ele mostrou um bom argumento, ele disse: “1 X 0" (como se ele tivesse marcado um ponto), como se aquilo tratasse de uma disputa. Iindiquei que ele aparentava estar sempre competindo. Otto ficou um pouco embaraçado, disse que não era bem assim. Falei que seria bom ele pensar sobre isso, se observar e ver se isso procedia ou não.

Lembrei o que ele havia falado sobre o avô, isto é, que ele o "botava para estudar” e disse que me interroguei se ele não estava precisando de alguém que o ajudasse a sustentar 
esse trabalho de aluno, que necessita de esforço, persistência, e, por vezes, parecia ser muito solitário. Otto entendeu a minha consideração e disse que não queria aulas particulares. Falei que não era essa a minha intenção, havia pensado em um atendimento psicopedagógico, para favorecer a ampliação das estratégias de pensamento, sistematização das normas da escrita, apropriação de instrumentos de compreensão da leitura e, sobretudo, ajudá-lo a agüentar quando essas coisas parecessem muito difíceis.

Ele concordou com a minha indicação e eu propus o atendimento uma vez por semana, tendo em vista as freqüentes tentativas de desmarcar as sessões durante o diagnóstico. Ele disse que achava melhor ser duas vezes por semana. Perguntei se tinha certeza e ele disse que sim. Fui bem clara - insisti que estávamos estabelecendo um contrato de trabalho e, se estávamos combinando duas vezes por semana, não seria possível ficar mudando a toda hora. Tratava-se de um compromisso, cada um teria suas responsabilidades. Lembrei que durante o diagnóstico tínhamos combinado que, se ele faltasse, ele avisaria o pai, mas, como ele não cumpriu isso, falei que eu comunicaria ao pai quando isso ocorresse. Otto assentiu.

\subsubsection{Atendimento psicopedagógico}

Propus ao Otto fazermos atividades para ajudá-lo a organizar suas estratégias mentais e ele concordou. Iniciamos o atendimento com uma série de jogos que trabalham com a idéia de permutação, como o jogo Senha. ${ }^{60}$ No diagnóstico havíamos jogado esse jogo de forma simplificada, com quatro cores já conhecidas, e ele sentiu certa dificuldade. Retomamos desta forma e, depois de duas ou três vezes, ele foi compreendendo a estrutura do jogo e avançamos para a forma mais complexa. Otto jogou bem e, na minha vez de descobrir, ele ficou exultante em verificar que eu acertei em 5 jogadas, ao passo que ele acertou em 4 (vence quem acerta em menos vezes).

Comentei que é assim mesmo, há vários fatores implicados em um jogo: estratégia, sorte, atenção, controle emocional, etc. Perguntei se ele achava que eu tinha jogado de forma incoerente e ele disse que não. Falei que para mim era isso que importava. De fato, ele não tinha aquela postura de jogar por prazer - jogava para ganhar.

\footnotetext{
${ }^{60}$ Fabricado pela Grow, trata-se de um grupo de pinos de 6 cores e um jogador escolhe 4 cores e faz uma combinação atrás de um anteparo que deve ser descoberta pelo outro jogador. O adivinhador deve dar um palpite e o jogador que fez a senha deve dar o resultado - 2 cores certas no lugar errado, por exemplo. E assim, sucessivamente, até o adivinhador descobrir a senha.
} 
O objetivo ao trabalhar com jogos é, primeiramente, desenvolver estratégias cognitivas: ao interagir com um jogo, procurar identificar a sua estrutura, focalizar a atenção para os aspectos mais importantes que o compõem e processar essas informações, combinando-as com suas experiências prévias. De posse das estratégias cognitivas, proponho um trabalho com as estratégias metacognitvas. Em uma primeira etapa, o sujeito aprende a jogar de forma quase automática, querendo dominar as variáveis que envolvem aquele jogo. Numa segunda etapa, procuro levar o sujeito a se interrogar sobre a estrutura do jogo, a elaborar estratégias conscientes, de forma a controlá-las e avaliá-las. O trabalho de metacognição favorece o pensamento sobre os próprios procedimentos mentais e a possibilidade de fazer um controle sobre os mesmos. A intenção é que o sujeito se interrogue sobre seus erros, seus acertos e procure criar formas de controle da produção cognitiva.

Propus outros jogos que trabalhavam com a mesma estrutura, e notei que ele parecia não fazer a abstração, que, segundo Piaget, consiste em aplicar um esquema aprendido ou construído de uma situação para outra. No jogo Cinco Letras, ${ }^{61}$ que é um pouco mais complexo, pois se trata de descobrir uma palavra de 5 letras, podendo usar todas as letras do alfabeto, Otto ficou bem desestabilizado. Jogou de forma assistemática e não conseguia avançar. Disse que o jogo era muito chato, fez cara de sono, enfim, mostrou um lado que eu desconhecia. Suspendi o jogo, falei que não tinha sentido ele jogar daquele jeito, sem se envolver. Combinei que em outro momento o retomaríamos, mudamos de atividade e ele voltou a ficar bem disposto.

O comportamento de iniciar algo, verificar o grau de dificuldade e querer parar, por conta do nível de complexidade, foi uma constante. Em vez de eu insistir e criar uma situação de resistência de sua parte, procurei oferecer outras atividades para criarmos um clima de colaboração, e não de oposição, que parecia ser o padrão que ele estava impondo nas relações com os adultos.

Certa vez, ele quis desistir de uma atividade do tipo “A César o que é de César”, 62 Apesar de se tratar de uma proposição formal, achei que ele já tinha adquirido certo repertório para enfrentar tal tarefa. De fato, essa atividade era bem desafiadora para ele. Diante de sua recusa a continuar, perguntei se ele queria que eu propusesse só coisas light, fáceis. Em outras

\footnotetext{
${ }^{61}$ Da empresa Perceber - Jogos e atividades, esse jogo é uma maneira formalizada do jogo de salão "Psico".

62 Segundo Macedo, Petty e Passos (1997), é um jogo que lida com permutas também, porém usando a linguagem escrita. Trata-se de uma modalidade individual de jogo do tipo do Senha. É como um quebra-cabeça, em que se deve articular algumas informações e estabelecer certas correspondências. É um jogo que trabalha com o raciocínio verbal e geralmente requer uma estrutura de pensamento hipotético-dedutivo.
} 
palavras, que o tratasse como "café com leite”. Ele disse que não, que ele podia fazer tarefas desafiadoras, mas aquelas que eu propunha eram “chatas”.

Pedi que ele desse uma chance à atividade, que conhecesse mais, para ver como aquilo era interessante. Disse que era um enigma, que havia informações que teria de articular, e faria como um detetive, que vai excluindo pistas falsas e deduzindo algumas informações. Além disso, o tema daquele enigma eram os imperadores romanos e eu tinha escolhido especialmente para ele, pois sabia que ele se interessava por História Antiga. Otto concordou em continuar, sentiu algumas dificuldades e fui dando algumas dicas. Por fim, ele entendeu a estrutura do jogo e resolveu o enigma. Ficou satisfeito e ainda aproveitou para se exibir um pouco, contando histórias sobre alguns daqueles imperadores. Essa situação foi importante para amenizar um pouco a atitude de oposição sistemática diante dos desafios. Depois disso, retomamos, gradativamente, as atividades que haviam sido suspensas anteriormente.

Já no primeiro mês de atendimento, Otto quis desmarcar uma sessão, ligando no próprio dia. Esse comportamento se repetiu diversas vezes. Combinei que não faria isso se não fosse com pelo menos um dia de antecedência e que eu avisaria seu pai caso isso acontecesse. Na primeira vez em que isso aconteceu, ele veio bem sem graça na sessão seguinte e disse que estava doente, mas veio por temor ao pai. Achei bom esse pai conseguir impor certa autoridade junto ao filho.

A situação escolar estava ficando difícil, Otto contou que alguns professores the deram falta por causa da ausência de material (geralmente o livro ou a lição) e duas vezes por ter saído da aula por ter conflito com o professor. Perguntei se nas vezes em que ele saiu da aula, estas não fizeram falta para compreender o conteúdo daquelas disciplinas. Ele reconheceu que sim. Comentei que tem escolas que, no Ensino Médio, deixam livre para os alunos a freqüência da aula. Os alunos acham isso ótimo, perdem muitas aulas e, quando se apercebem, estão totalmente defasados em relação aos conteúdos. Concluí: em primeiro lugar, alguns alunos não sabem lidar com a liberdade que lhes foi dada e, em segundo, a melhor forma de aprender é com alguém que sabe mais e que gosta daquela disciplina - o professor.

Na semana seguinte, ele contou que teve um problema com o professor e estava quase saindo da aula, quando se lembrou que teria uma prova na semana seguinte e que aquela seria a última aula antes da avaliação. Lembrou-se do pai, pensou que, se este soubesse daquele atitude do filho, iria ficar bravo e, por fim, decidiu ficar. 
Aquele episódio me fez pensar em algumas coisas. A primeira, era que aquele pai estava conseguindo exercer certa autoridade junto ao filho pois, antes de sair da classe, ele se lembrou da figura paterna como uma instância superior que regula, que controla. E Otto necessitava muito disso. A segunda, é que ele estava tentando entrar no jogo escolar, apesar de que isso só acontecia na semana de provas. Parecia uma forma instrumental de se colocar diante da ordem escolar, mas isso poderia se transformar no futuro. O primeiro passo era “estar dentro do jogo", como a experiência que tivemos com o enigma do "A César o que é de César”. Outro ponto a salientar é que ele estava conseguindo se antecipar, saindo da situação imediatista, e pensar no futuro.

Tendo em vista que Otto ainda tinha algumas "pendências” com o nível concreto, procurei explorar com ele uma diversidade de materiais e situações que começassem no plano concreto e conduzissem para a abstração. Assim, propus a ele uma atividade de geometria, que constava de desmanchar um cubo de papel, observar como ele havia sido concebido no plano euclidiano, isto é, a relação entre as faces - de oposição, vizinhança, etc. - e, em seguida, planejar outras formas de montar um cubo. Ele tinha de imaginar primeiro e depois desenhar no papel quadriculado, usando o plano topológico. Por fim, ele tinha de recortar e tentar montá-lo, para ver se o seu projeto tinha sido bem-sucedido ou não. Otto apresentou grande dificuldade e eu brinquei que seria sua secretária, iria recortar para ele, pôr junto aqueles que eram parecidos, para ele comparar se havia outras variações possíveis, etc.

Vale assinalar que, em quase todas as atividades, eu fazia uma mediação. Era raro ele conseguir fazer algo sem a minha ajuda. No entanto, depois de se familiarizar com o desafio, eu o deixava trabalhar sozinho. A mediação era necessária para o objeto de conhecimento não se transformar em objeto de pulsão e para ele não criar um subterfúgio para parar a atividade.

A atividade de comparar os cubos já feitos foi bem importante, pois ele conseguiu realizar uma classificação e executou certas variações dentro daqueles modelos. Essa atividade levou duas sessões para terminar e, no fim, ele disse que só havia conseguido finalizar a tarefa por causa da minha ajuda. Achei interessante, pois a nossa relação estava se convertendo em uma relação de colaboração e de troca. Otto parecia não mais necessitar competir comigo.

Na retomada de alguns jogos que havíamos interrompido, como o Cinco Letras, Otto mostrou-se bem confuso e eu falei que também estava achando difícil a palavra que ele havia inventado. Ele ficou bem aliviado de me ver nessa situação e falou que às vezes temia que não ia conseguir resolver certos desafios. Comentei que todos sentem isso, e há situações em que 
isso realmente acontece, isto é, o sujeito fracassa, como um médico, que não consegue ajudar um paciente a se curar. A questão é não desistir logo de saída.

Em certa sessão, Otto liga para mim 10 minutos antes do início e quer desmarcar. Digo que não concordo e que, se ele não vier, vou considerar falta. Ele vem correndo e me conta que tirou notas ruins. Disse que não estudou o suficiente, saiu com freqüência com os amigos naquele bimestre. Em seguida, diz que vai se recuperar, como se isso dependesse de sua vontade.

Aponto que nesse dia ele tinha conseguido fazer uma coisa que eu achava uma conquista - conseguiu adiar para mais tarde o que gostaria de fazer e veio aqui. Comentei que ele poderia utilizar essa experiência para a experiência escolar, ou seja, estudar para a prova antes e sair depois com os amigos, e não o contrário, pois, muitas vezes, ao sair com os amigos, ficava cansado ou não tinha mais tempo para estudar. Comentei que iria à escola para conversar com o coordenador para conversarmos e vermos como poderíamos ajudá-lo diante de sua situação escolar.

Fui à escola e o coordenador comentou que Otto estava bem perdido, era muito solto, não havia muito controle por parte do pai. Teve a mesma percepção que eu havia sentido em relação à figura paterna: uma grande ambivalência para exercer a autoridade. O pai havia procurado o coordenador naquele dia para comunicar que o filho iria morar em um outro apartamento e que o pai iria junto. Achei melhor entrar em contato com o pai para entender melhor a questão e levantei a possibilidade de indicar aulas particulares para Otto, com o que o coordenador concordou.

O pai também entrou em contato comigo naquele mesmo dia e marcamos uma entrevista. Nesta, ele relatou que a situação entre Otto e a madrasta andara muito difícil e o filho quisera “dar um tempo” e ir para a cidade natal, junto da avó. Para amenizar a situação, o pai propusera ao filho ir morar em um apartamento perto de sua casa, que ele mantinha como escritório. De início, o pai dissera que iria morar com ele, depois recuou. Apontei que Otto estava tentando fugir dos problemas. Ele mostrava que tinha dificuldade para manter o esforço necessário para alcançar o sucesso na escola e também para estabelecer uma boa relação com a nova família. Observei que o pai parecia estar fazendo o mesmo, estava desistindo de ser pai, não estava mantendo o investimento necessário para dar ao filho a estabilidade e a segurança de que ele necessitava. 
Falo que Otto necessitava de uma rotina estável, de muito controle, da presença de um adulto que fosse exigente, mas que também cuidasse dele. Era óbvio que ele não teria isso morando em um apartamento sozinho. O jovem tinha apenas 16 anos e não tinha maturidade para cuidar de si. O pai retrucou que tentaria estar presente o máximo possível.

Esse pai estava muito constrangido por ter de utilizar subterfúgios para impedir que o filho voltasse para o Nordeste. Disse para Otto que ele não poderia viajar, pois o pai não tinha os documentos necessários para ele viajar sozinho. Falei que todos os pais, diante de determinadas situações fazem isso, para não criar ainda mais conflitos com os filhos. Ponderei que aquela situação era muito delicada e que ele usara o recurso que estava ao seu alcance. Seria importante não abusar disso, senão ele poderia perder a confiança do filho.

O pai estava se dando conta da situação sui generis em que se encontrava: ele tinha um filho cuja mãe era sua mãe. Creio que estava entrando em contato com suas questões pessoais na análise. Considero que a avó já estava muito cansada e não tinha mais condições de cuidar dele. Lembro que Otto veio para São Paulo, pois ele também estava tendo problemas por lá. Seria ilusório o jovem acreditar que voltar para a cidade natal representaria a solução de seus problemas.

De acordo com o pai, Otto pediu para fazer terapia e o pai lhe deu o nome e o telefone de um profissional. Digo que ele poderia perguntar ao filho se ele gostaria que o pai marcasse a entrevista para o filho, já que ele sempre fora tão resistente a isso. Comento que a autonomia é saber cuidar de si, aprendendo com os pais como eles próprios cuidam do filho. Creio que o ideário de educação libertária do pai não dá lugar para esses gestos significativos. Em nome de uma autonomia idealizada, os pais acabam negligenciando os filhos.

Por fim, o pai está consciente de que os verdadeiros pais de Otto sempre foram os avós. Está ansioso para construir uma nova relação com o filho e teme que esta seja a última chance. Fica claro que Otto faz uso disso. Segundo o pai, ele lhe disse, referindo-se ao avô: “- Meu pai está morto”. Digo que o momento é delicado, mas não é definitivo. Seria importante manter toda a atenção e controle sobre Otto, pois ele não saberia lidar com tamanha liberdade. Seria importante enfatizar que essa situação seria provisória e que juntos eles iriam procurar uma outra solução.

Combinei que conversaria com Otto sobre as aulas particulares e nos comprometemos a manter um contato freqüente. 
O atendimento psicopedagógico transformou-se depois de efetivada a mudança de casa. Otto começou a falar mais da sua vida pessoal. Indiquei que ele parecia apresentar uma nova demanda, necessitava de um outro espaço, um lugar para falar sobre suas coisas íntimas, de entender seus sentimentos, o que se passava à sua volta, o motivo que o levava a criar conflitos com os adultos, etc. Enfim, necessitava de uma análise. O jovem concordou.

Também ficou claro que ele precisava de aulas particulares, pois suas defasagens pedagógicas estavam ficando bem acentuadas e seria difícil superá-las sozinho. Otto achou boa a idéia. Ressaltei que não adiantava nada contratar novos profissionais, acreditando que, se ele "recebesse" mais, iria resolver seus problemas. Ele também teria de assumir uma postura ativa, e não só os profissionais. Se não houvesse um compromisso de sua parte, tudo continuaria igual. Dei o exemplo de seu compromisso comigo - faltara algumas vezes, tentara desmarcar algumas sessões. Otto ficou desconcertado e disse que iria se organizar e não mais repetiria isso.

Iniciou tanto o processo terapêutico, ${ }^{63}$ como as aulas particulares.

Depois de certo tempo, no que diz respeito ao tratamento psicopedagógico, Otto deu um salto qualitativo. Assumiu uma postura bastante comprometida com o nosso trabalho. Começou a articular mais seus esquemas, a encadear uma sessão à outra, percebendo seu processo. Passou a relacionar as coisas que aconteciam na escola com o seu funcionamento como aprendiz, como sujeito, e em sua relação com o conhecimento.

As aulas particulares o ajudaram a acompanhar o conteúdo escolar e ele entrou, de fato, no jogo escolar. Contou que estava anotando as aulas no caderno, coisa que jamais havia feito. Começou a estudar com os amigos e iniciou novas trocas, não só no nível social, mas também no campo do conhecimento.

A escola passou a fazer sentido e ele me contava dos trabalhos escolares que estava realizando. Conseguiu ver qualidades em professores que antes detestava, como o professor de Português. Ficou muito mobilizado com a leitura do Inferno, de Dante. ${ }^{64}$ Disse que era ainda mais interessante do que o Príncipe, de Maquiavel, que já havia lido. Antes, falava dessa última obra para se exibir, mas, agora, lia Dante com um interesse genuíno, e queria fazer o trabalho de reescrita à altura do seu envolvimento. Levou para mim e trabalhamos

\footnotetext{
${ }^{63}$ Apesar de haver iniciado esse atendimento, não havia uma sistematicidade, Otto marcava uma sessão quando queria. Não cheguei a conversar com o profissional responsável, apesar de haver tentado entrar em contato com ele.

${ }^{64}$ Divina Comédia, Dante Alighieri.
} 
juntos sobre ele. Funcionei como o ego auxiliar, lembrava as normas gramaticais, mas também fazia uma leitura crítica, apontando frases que não ficaram claras, entre outras coisas. Sua produção escrita converteu-se em "ao mesmo tempo trabalho do pensamento, trabalho de linguagem e trabalho de subjetivação”, segundo Bautier e Rochex (2001, p. 132). Vale assinalar que ele ainda sobrevalorizava o conteúdo em detrimento da forma. Não se preocupava com a ortografia e demais regras e dizia que, no fim era "só pôr no Word" e pronto".

Otto trouxe um exercício de Biologia e disse que tinha pensado em mim, pois ele era parecido com aquela proposição do tipo “A César o que é de César”. Estava um pouco constrangido, pois o professor havia recomendado para resolver sozinho. Falei que ele podia fazer sozinho e eu iria acompanhá-lo. Caso necessitasse de ajuda, eu não iria pensar por ele, mas sim com ele, como sempre fazíamos. Ele ficou mais tranqüilo e examinamos o material. Era sobre Taxonomia de Lineu: a classificação dos seres vivos em reinos, ordens, família, etc. Ele não sabia como era a hierarquia dos seres vivos e tampouco trouxera o livro. Sugeri procurarmos na enciclopédia e notei sua dificuldade para usar esse tipo de material. Em seguida, propus que fizesse uma tabela, para ir organizando os dados. Por fim, ele foi colocando esses dados na tabela e cruzando as informações, até deduzir alguns pontos importantes.

Não terminou a tarefa comigo. Lembrei que, no final, ele teria de checar todas as informações, para ver se haveria alguma contradição, pois muitas vezes isso acontece, como já havia ocorrido conosco com o exercício “A César o que é de César”. Deveria realizar um controle da sua produção cognitiva. Ele disse que já tinha entendido, era "simples".

Na sessão seguinte, contou que, na correção em classe, o professor o ridicularizou por causa de uma conclusão a que ele havia chegado. Ficou claro que, em casa, ele não monitorou todo o processo, isto é, não chegou a checar todas as informações de forma a criar uma solução final coerente. Ao sentir-se exposto, ficou bravo, quase brigou com o professor, mas, novamente, lembrou-se do pai e conseguiu se controlar. Comento com ele que isso me lembrava a história de $O$ médico e o Monstro, de Robert Louis Stevenson. Perguntei se ele conhecia a estória e ele disse que já tinha ouvido falar sobre ela. Propus lermos juntos e ele ficou hesitante.

\footnotetext{
${ }^{65}$ Editor de texto da Microsoft.
} 
Otto conta que estava tenso por motivos particulares, pois sua avó havia feito um exame para diagnosticar se tinha câncer e o resultado sairia em breve. Essa era a justificativa de ter quase perdido o controle emocional em classe.

Em relação à leitura, relata que teve de ler para a escola $O$ Estrangeiro, de Camus, e não entendeu nada. Seu pai fez um resumo para ele. Disse que isso o havia ajudado naquele momento, mas seria necessário trabalharmos com compreensão de leitura, para ele adquirir autonomia e não precisar que lessem por ele.

Iniciamos, então, um trabalho mais dirigido para leitura. Propus textos jornalísticos, contos, crônicas e textos informativos. Levantamos estratégias metacognitvas de leitura, de acordo com Kato (1985) e Mabel Condemarin, Viviana Galdames e Alexandra Medina (1997). Otto envolveu-se muito e começou a perceber que há uma forma mais analítica de ler, quando se trata de um assunto novo ou um texto complexo, e uma forma sintética, quando se trata de algo familiar. ${ }^{66}$ No caso de Otto, predominava o segundo tipo, não importando o tipo de texto. Vimos que ele necessitava aprimorar sua forma de ler, criar mais estratégias de leitura.

Estávamos já no fim do semestre, quando o pai me telefona pela manhã e conta que o filho havia passado dos limites. Ele fumara maconha com os amigos no terraço do apartamento e os vizinhos se escandalizaram com isso e reclamaram com o pai. Otto estava com o celular desligado e o pai queria que o filho entrasse em contato com ele. Falei que me parecia que ele não estava sabendo lidar com tamanha soltura. Talvez essa fosse uma forma indireta de ele solicitar limites do pai. Apesar disso, no que dizia respeito à escola, apontei que ele estava bem mais envolvido. O pai concordou. Combinamos manter-nos em contato.

À tarde, Otto chegou bem diferente. Estava excessivamente à vontade, falando alto, rindo à toa. Foi ao banheiro e ficou bastante tempo lá. Contei a ele que o pai havia ligado, estava preocupado e desejava conversar com ele. Ele nada disse a respeito. Observei que ele estava muito diferente e que eu o estava estranhando. Otto estava bastante dispersivo e foi muito difícil fazê-lo trabalhar. Propus terminar uma atividade de escrita, que havia iniciado na sessão anterior, mas ele encontrou bastante dificuldade para realizá-la.

\footnotetext{
${ }^{66}$ Segundo Kato (1985), o primeiro esquema corresponde ao processamento top-down, do todo para as partes, e o outro seria o processamento botton-up, das partes para o todo.
} 
Tratava-se de um texto, que havia lido na sessão anterior, e agora eu lhe dera o mesmo texto, porém agora ele continha algumas lacunas, ${ }^{67}$ que ele deveria preencher de forma a dar sentido às frases. Tinha de usar pistas gramaticais, semânticas e seus conhecimentos prévios para realizar a tarefa. Principalmente, tinha de monitorar sua compreensão, para ver se a nova versão do texto estava ficando coerente. Essa atividade foi muito custosa para ele. Preencheu as lacunas em silêncio. Depois comparamos com o texto anterior e constatamos que havia falhado em várias palavras; ele mesmo percebeu que havia cometido várias incoerências.

Perguntei se algo havia acontecido, se havia chegado o resultado do exame da avó. Ele disse que não. Achei que ele estava sob o efeito da maconha, mas, se ele de fato havia fumado, não seria bom conversar naquela hora. Tentei deixar bem claro que o tinha achado muito diferente naquela sessão. Creio que nesse dia entrei em contato com a fragilidade e a desorganização de Otto, que ele mantivera à distância até então.

De fato, conforme o pai havia comentado pela manhã, ele havia ultrapassado os limites. Senti que ele havia quebrado nosso compromisso de trabalho e decidi que seria bem dura na sessão seguinte, no entanto fiquei penalizada com a situação. Refletindo mais tarde sobre aquela sessão, pensei que tinha sido constrangedor vê-lo daquele jeito. Estava “aéreo”, não conseguia fazer nada direito. Se aquele estado em que se encontrava lhe parecia interessante para conversar com os amigos, ver televisão, jogar videogame, etc., certamente não se adequava para o atendimento psicopedagógico, nem para a escola, e, menos ainda, para estudar. Ele não estava sabendo dosar o uso da maconha e necessitava de um limite. Porém, ficou claro que não deveria ser eu a fazer isso, mas o pai.

Otto faltou na sessão seguinte e eu comuniquei o fato à madrasta. Na semana seguinte, conversei com o pai pelo telefone e falei da minha suspeita de que ele havia fumado antes de vir à sessão. Ele estava irritado e dizendo ser difícil fazer o controle do filho. Falei que Otto estava clamando por limites e isso só poderia vir da figura paterna.

Na sessão seguinte, Otto chegou bem envergonhado, disse que tinha "furado" comigo. Ele ficou esperando uma bronca e eu perguntei se estava tudo bem e ele disse que sim. Ambos estávamos constrangidos. Ele, pela demonstração do seu lado de $M r$. Hyde que manifestara na sessão anterior, e eu, por ter me sentido o Dr. Jekyll: aquele adulto que encarna as virtudes e condena as atitudes mais hedonistas, de busca de prazer.

\footnotetext{
${ }^{67}$ Técnica de close, de levar o sujeito a deduzir as palavras ocultas, no sentido de fazer uma leitura mais analítica.
} 
Não daria para fazer um discurso moralista com um adolescente cujo esforço e envolvimento no atendimento psicopedagógico eu testemunhara até então. Procurei encarar aquilo como um desvio de percurso, e, se aquele fato constituísse um único episódio, teria sido um acontecimento isolado dentro de um processo que estava sendo positivo. Era claro o meu desconforto diante daquela situação, e achei por bem aguardar uma outra oportunidade para falar sobre aquele acontecimento de forma mais distanciada e que não ameaçasse o nosso compromisso de trabalho.

Estávamos no fim do semestre e nos debruçamos intensamente sobre as estratégias metacognitivas da leitura. Otto lia e depois fazia um registro escrito, ou eu propunha alguma atividade de compreensão sobre o mesmo. Para escrever, agora utilizava o lápis, para realizar uma produção com mais pertinácia, mais elaborada, do ponto de vista formal. Parecia bem mais cuidadoso. Propus a ele a leitura do conto "O Espelho", de Machado de Assis. ${ }^{68}$ Queria observar se o tema da necessidade de reconhecimento social, trabalhada no conto, poderia propiciar a discussão sobre sua relação com a maconha e com o grupo de amigos. A leitura foi bem difícil, pois se trata de um conto complexo, mas ele interessou-se muito. A proposta era que ele lesse uma parte em silêncio e depois me contasse o que havia compreendido. Otto ficava irritado de ter de fazer essas paradas e se reportar a mim, mas eu dizia que isso era um exercício de monitoramento da compreensão de leitura, e que essas pausas permitiam verificar se o texto estava claro, se a narrativa era verossímil para ele.

Houve um momento curioso, quando comentei ironicamente que, naquele conto, ser alferes, ${ }^{69}$ que consistia no posto do protagonista (o que para mim parecia insignificante), era considerado por todos uma ocupação muito importante. Ele retrucou: “- Mas isso é uma honra”. Ou seja, havia nele um lado mais formal, tradicional, que eu não percebera até então. Quem diria, ele, um adolescente tão crítico e liberal, valorizava um posto militar e a bandeira nacional. Talvez por grande parte de sua formação ter sido no nordeste, onde essas coisas podem ser mais valorizadas. Não houve tempo para ampliarmos a discussão para o tema da identidade e do grupo, como eu desejava. Na verdade, gostaria de discutir com ele a necessidade de ser igual aos amigos, fazer tudo o que os outros fazem, para ser aceito e reconhecido pelo grupo. Deixei isso para outra oportunidade.

\footnotetext{
${ }^{68}$ Contos - Machado de Assis. Rio de Janeiro: Paz e Terra, 1997.

${ }^{69}$ Segundo o Antônio Houaiss (2001), trata-se do posto no exército do porta-bandeira; patente de oficial abaixo do tenente.
} 
Otto havia feito muitas conquistas. Estava comprometido com o nosso trabalho e tinha evoluído, do ponto de vista cognitivo. Também apresentava uma postura mais aberta às acomodações, no sentido piagetiano, no processo de construção do conhecimento. E, ainda, parecia ter entrado na ordem do trabalho escolar. Apesar de todas essas conquistas, Otto estava um pouco desanimado, dizendo que tinha de estudar muito.

Todo o esforço que vinha mantendo parecia não ser suficiente para assegurá-lo para as provas finais. Contou que não havia estudado para uma prova. Falei que, naquele momento, mais do que nunca, tinha de manter o esforço, senão colocaria em risco o empenho dos últimos tempos.

Talvez ele duvidasse dos seus recursos. Lembrei de algumas situações por que passamos juntos, quando manifestou o temor de não conseguir dar conta de uma tarefa, e frisei que seria importante ele se deparar com o resultado dos seus esforços, com a realidade. Diante dos resultados da avaliação, teria de se posicionar. Havia a possibilidade de o resultado não ser o esperado, mas isso indicaria que ainda seria necessário um esforço adicional. Contudo, nada disso seria possível antecipar naquele momento.

Ele queria “conversar”, se dizia muito cansado para trabalhar. Conversamos sobre as férias de julho, a fim de combinar como faríamos com o atendimento psicopedagógico. Ele contou que iria passar um mês na sua cidade natal, junto da avó. Falei que o meu plano seria trabalharmos mais uma semana, porém, tendo em vista que estava saudoso de sua cidade, achei que merecia esse mês de férias. Ficou estabelecido, então, que teríamos somente uma sessão a mais. Procurei propor uma atividade mais simples, (tendo em vista seu cansaço), para não passar a mensagem de que agora podia “relaxar”.

Na última sessão do semestre, a disposição de Otto para trabalhar estava quase a zero. Queria “bater papo”. Disse que não havia estudado para a última prova, mas que fizera uma leitura bastante aprofundada, ficara atento ao texto e, principalmente, às questões. Disse que se lembrara de mim, das coisas que havíamos trabalhado juntos. Falou que tinha percebido que o tratamento psicopedagógico o estava ajudando. Fiquei contente com tal percepção, e ainda mais, com o fato de ele se apropriar de esquemas e procedimentos que trabalháramos juntos.

Vale assinalar que ele disse que se lembrara de mim. Em sua representação, esses instrumentais ainda estavam relacionados à minha pessoa, o que mostrava que ainda seria 
necessário trabalharmos mais, a fim de que tais instrumentos perdessem tal atributo e se tornassem algo próprio.

Ainda propus o jogo "Leréia", ${ }^{70}$ que trabalha com a dedução do significado das palavras. De início, ele usava pistas mais fonéticas, mas estas se mostraram falhas em muitas situações, daí passou a utilizar pistas semânticas e, mais tarde, etimológicas, o que melhorou sua performance. Terminamos o semestre de forma positiva, com o compromisso de prosseguirmos o atendimento depois das férias, em dia já pré-estabelecido.

No final de julho, o pai me telefona para comunicar que o filho iria interromper o tratamento. A avó havia decidido pelo retorno de Otto à sua cidade. Ela tivera conhecimento das suas dificuldades escolares e, sobretudo, do fato de o neto estar fumando maconha. O pai conta que não havia ocorrido uma conversa entre os três, mas, sim, uma decisão unilateral por parte da mãe. Ele conta que no semestre que se iniciaria iria trabalhar três dias da semana fora de São Paulo e que ficaria difícil acompanhar a vida de Otto de forma mais rotineira. Não poderia ajudá-lo a manter a estabilidade necessária. Ele reconhece que foi penoso controlar o filho no semestre anterior e afirma que, afinal, a mãe dele tinha os pátrios poderes. Cabia a ele aceitar esse fato. Achei que o pai estava aliviado por essa decisão e ficava confortável atribuir a ela a decisão, como se ele não tivesse responsabilidade sobre Otto.

Ressaltei que, diante dessa decisão, seria importante mostrar para Otto que esse semestre não fora em vão, que ele havia construído muitas coisas junto ao pai, ao grupo de amigos, à escola, comigo, enfim, havia criado laços em sua experiência em São Paulo. Combinamos que Otto viria na semana seguinte para se despedir de mim e para finalizarmos o tratamento. Também marquei uma entrevista com o pai, com o mesmo intento: realizar um balanço desse processo.

Otto veio para a última sessão ávido para contar coisas que tinha vivenciado nas férias. A primeira coisa que queria compartilhar comigo é que estava namorando uma jovem de sua cidade e estava encantado com a convivência mais íntima com uma adolescente. A segunda coisa era o retorno para sua cidade, que tinha sido uma decisão da avó. Perguntei o que ele achava disso. A princípio, não se importou, “entrou no clima”, segundo ele, mas, agora que tinha vindo para cá, havia percebido que iria sentir falta de algumas coisas.

Fomos levantando tudo o que havia construído por aqui, as amizades com os colegas, a relação com a escola, e demos ênfase às questões de sua aprendizagem.

\footnotetext{
${ }^{70}$ Jogo da empresa Grow inspirado no “Dicionário”, um jogo de salão.
} 
Apontei que ele tinha realizado várias conquistas e fomos enumerando-as e comentando sobre cada uma. Comentei que ainda havia muita coisa a ser feita, e também indiquei quais coisas ele ainda tinha de cuidar, quanto à aprendizagem. O mais importante era manter o investimento no ofício de aluno, não adiantava se empolgar no início e depois abandonar o trabalho.

Questionei se aquele retorno não havia sido uma fuga, uma saída fácil para os problemas que havia criado no semestre anterior. Ele disse que lá as coisas não seriam nada fáceis. Contou que, na escola em que iria estudar (a última que havia freqüentado antes de vir para São Paulo), as classes do Ensino Médio tinham 60 alunos, ao passo que aqui, apenas 25 alunos. Isso iria fazer diferença para ele, pois o contato não seria tão próximo com os professores.

Conversamos sobre a experiência de ter morado sozinho, observei que ele ficara muito solto e que muitas vezes me pareceu não saber dosar as coisas. Contei que seu pai me relatou sobre o fato de ele estar fumando maconha e falei que achei que, numa certa sessão, ele estava sob o efeito da maconha. Ele confessou que sim, lembrou-se daquela sessão. Disse que estava fumando com muita freqüência no semestre anterior. Apontei que isso provavelmente havia prejudicado o seu desempenho escolar e ele disse que não. Falei que naquela sessão, especificamente, ele estava muito dispersivo e teve dificuldade de trabalhar. Ele ficou reticente.

Comentou que, na sua cidade, seus amigos não fumavam, e que no meio que lá freqüentava isso não era bem visto. Comentei que aqui, ou na sua turma daqui, todos precisavam fumar, era como usar a farda de alferes, ${ }^{71}$ para ser reconhecido no grupo. Ele concordou.

Enfim, foi uma conversa em que procurei marcar a diferença geracional em relação a Otto. Eu era uma adulta e não tinha prurido de ser chata, de lembrar das coisas trabalhosas que lhe cabiam. Mostrei que meu papel é favorecer a mediação entre o sujeito e a cultura, e o meu compromisso era levá-lo ao mundo dos adultos, das trocas simbólicas. Mundo feito de gratificações a longo prazo e que reserva muito prazer àqueles que se submetem a ele.

Despedimo-nos calorosamente e lhe disse que o semestre anterior havia sido muito produtivo para nós dois. Entre outras coisas, ele deixara marcas em mim.

\footnotetext{
${ }^{71}$ Remeto o leitor ao conto "O espelho", de Machado de Assis. Naquele contexto, o alferes só se sente reconhecido se está vestido com o uniforme de alferes, caso contrário se sente destituído de identidade.
} 
Esse caso ilustra bem algo freqüente na relação pais e filho no contexto da contemporaneidade - o enfraquecimento das barreiras geracionais. Aqui, mais ainda, vemos um pai que se recusa a exercer a função paterna, negando-se a marcar a diferença de geração. Colocando-se como um igual, tão confuso e “perdido” quanto o filho.

Havia nessa família, uma confusão geracional, em que vários papéis se opunham e muitas vezes a reciprocidade não era possível de ser estabelecida. A primeira denúncia partiu do próprio pai, que disse estar em uma situação sui generis, pois ele tinha um filho cuja mãe era a sua própria mãe. Se a avó era a mãe do adolescente, então pai e filho estabeleciam uma relação biunívoca com a mesma figura familiar. Em certo sentido, eram irmãos. E o pai não fazia a menor intenção de marcar a sua diferença geracional em relação ao filho, pois parecia ter se acomodado àquela situação. Dessa forma, ele estava condenado a jamais ter legitimidade para exercer a autoridade junto ao filho.

De acordo com Jeammet (2007), a diferença geracional coloca o adulto numa posição educativa que propicia a organização da personalidade em formação do adolescente. Nesse sentido, a educação se traduz em limites, de um lado, e cuidados, de outro. Os pais dos dois jovens em questão, Fábio e Otto, parecem cometer um equívoco, pois negam tal diferença e dão aos filhos liberdade, mas acabam por abandoná-los. O sintoma na aprendizagem desses jovens parece sinalizar que algo lhes falta e, por isso, acabam se colocando numa situação de extrema dependência em relação aos adultos.

Nesse sentido, o problema de aprendizagem parece estar relacionado à problemática da adolescência, mais especificamente ao paradoxo que esta coloca: a necessidade de receber dos adultos algo que lhes falta, em oposição ao anseio da constituição da própria autonomia.

No próximo capítulo vou me aprofundar sobre a adolescência como etapa que demanda um trabalho psíquico do sujeito, tendo em conta as transformações por que passa o jovem: o corpo, os laços afetivos, os interesses intelectuais e, sobretudo, os anseios. A referência teórica utilizada para tal análise será a dos psicanalistas Philippe Jeammet e Maurice Corcos. De posse de mais fundamentos, retomaremos mais à frente a questão do problema de aprendizagem em conexão com a problemática da adolescência. 


\section{Adolescência}

\subsection{O trabalho subjetivo decorrente das transformações da adolescência}

No capítulo anterior, apresentamos dois relatos de casos, abordados no âmbito da psicopedagogia. A partir do aprofundamento sobre a singularidade de cada sujeito, pretendemos, agora, confrontá-la com o contexto mais amplo, com os elementos que parecem comuns aos jovens na contemporaneidade. Para isso, vamos investigar os eixos que constituem a adolescência, tendo como referência a psicanálise. Cabe marcar que a adolescência se compõe por diferentes aspectos: o aspecto biológico, relativo à puberdade, o aspecto social, relativo ao estabelecimento dos laços sociais, e, por fim, o aspecto psíquico, que diz respeito ao processo estruturante que afeta a vida psíquica do jovem.

Nesse sentido, vamos nos debruçar sobre a adolescência a partir do referencial de Philippe Jeammet e Maurice Corcos (2005), que a entendem como um trabalho psíquico de articulação do mundo interno com o mundo externo. Esses autores apontam o conflito que emerge na adolescência entre as aspirações à autonomia e as tendências que acabam por manter o estado de dependência em relação aos pais. Jeammet e Corcos estão atentos para o papel do ambiente na manutenção ou na resolução desse conflito.

Daremos início, então, a uma reflexão sobre a passagem da adolescência, enfatizando o trabalho subjetivo do jovem para encontrar um novo lugar na sociedade, distinto do mundo familiar, bem como os obstáculos que ele encontra, numa sociedade que exalta a juventude e parece não favorecer o estabelecimento de uma vida adulta.

O processo de individualização, empreendido pela modernidade, teve na cronologização da vida, na institucionalização das idades de vida, um de seus aspectos fundamentais (DEBERT, 1999). É desse período que emerge a noção de infância, segundo Ariès (1973), e, junto com ela, são criados dispositivos de controle e de disciplinarização da criança, a começar pela institucionalização da escola.

Se a infância passa a ser regulamentada institucionalmente, a etapa seguinte, a adolescência, não tem um padrão uniforme de regulamentação, uma vez que, por definição, era entendida como passagem. Nesse contexto, a juventude é entendida como o período que 
inicia na puberdade e se estende até a vida adulta. Porém, o jovem é visto em uma condição de menoridade social, sendo, portanto, como a criança, um ser em formação.

Em muitas sociedades, para alguns autores, e mesmo historicamente no Ocidente, até o advento das transformações do século XVIII, observava-se a presença de ritos de passagem, que marcavam e delimitavam a entrada da criança no mundo adulto. Essa forma de regulação sofre um declínio progressivo no Ocidente, os ritos de passagem tendem a desaparecer e o controle social passa a se dar por meio de uma integração parcial do adolescente ao mundo adulto.

Segundo Serge Lesourd (2004, p. 22), até o século XIX, havia três modos de integração: o trabalho, a incursão a outra escola ${ }^{72}$, ou a mudança de status, dentro das ordens profissionais.

Vale assinalar que grande parte dos jovens não podia dedicar-se aos estudos longos, pois isso era franqueado somente às classes privilegiadas (DUBET, 1996; MARGULIS e URRESTI, 1998). Assim, o trabalho e a mudança de status profissional consistiam nas formas mais usuais de integração para a maioria dos jovens.

Há uma grande polêmica acerca do advento da adolescência nas sociedades ocidentais. A maioria dos autores concorda que a juventude, como fenômeno social, surge no pós-guerra, mais especificamente, com a emergência da cultura juvenil de massa. Trata-se de uma cultura sintonizada com os novos tempos, própria da sociedade que sofre uma horizontalização em virtude da desestabilização dos princípios hierárquicos.

Gilles Lipovetsky (2006) descreve essa transformação como o processo de “personalização” que se dá em todas as esferas sociais. Esse processo diz respeito ao aguçamento do princípio moderno do individualismo, invertendo a ordem anterior baseada na subordinação do sujeito às instituições, em prol da realização pessoal e da livre expressão.

A indústria cultural transmite uma série de referências e de imagens veiculando valores com os quais os jovens se identificam, como a autonomia, a expressividade e a individualidade (DUBET, 1996b, p. 26). Um representante bastante significativo dessa cultura é o rock, que recebe uma adesão em massa e cria um sentimento de unidade nessa geração, apesar de todas as clivagens sociais.

\footnotetext{
${ }^{72}$ Aqui podemos entender uma escola que dá continuidade aos estudos, um conservatório ou qualquer tipo de formação, que poderia também ocorrer no ambiente privado.
} 
Assistiremos, com as transformações da sociedade contemporânea, a um processo que Debert (1999) chama de “descronologização da vida”. As mudanças de costumes, no mundo do trabalho e na família tornam a idade cronológica irrelevante; a idade para casar, para ter filhos, para se tornar um adulto, fica variável. Os comportamentos se desatrelam da idade cronológica - uma mãe pode vestir-se como uma jovem, crianças têm acesso a conteúdos na TV que antes eram vistos como impróprios, etc.

No que diz respeito à adolescência, o fenômeno da descronologização manifesta-se sob a forma de um prolongamento dessa etapa da vida. A adolescência inicia com a puberdade, mas o final é difícil de determinar a priori. Segundo Philippe Jeammet e Maurice Corcos (2005), muitos fatores contribuem para isso, como o prolongamento da escolaridade, a demora para entrar no mundo do trabalho e a espera para o estabelecimento de uma relação conjugal.

O fator que parece prolongar ainda mais a adolescência é a ausência de dispositivos e de referências identificatórias que propiciem ao adolescente o estabelecimento de laços sociais e a realização de projetos. Por meio destes, o jovem pode fazer uma antecipação, ter uma determinada visão de como será e do que poderá realizar no futuro.

Vale notar que Jeammet e Corcos são psiquiatras e psicanalistas, mas não se restringem a uma visão clínica, no sentido estrito. Procuram entender as ressonâncias do contexto sociocultural na psique humana, por isso estabelecem um diálogo com várias esferas do campo social para compreender os elementos que propiciam a emergência das patologias narcísicas na adolescência no contexto da contemporaneidade. Fazem uso, portanto, da psicanálise extensa para verificar, nas tendências sociais, elementos que podem favorecer a manifestação das ditas patologias do agir nos adolescentes.

Para os autores, a adolescência pode ser entendida como o momento em que o jovem deixa as referências familiares para encontrar novas referências em outras esferas. Nesse sentido, é fundamental para o adolescente o reconhecimento social. Antes, esse processo era sustentado pelos ritos de passagem, porém eles declinaram na modernidade. Para Lesourd (2004, p. 179), a sociedade não oferece mais dispositivos que permitam tal reconhecimento, não nomeia os lugares possíveis que o jovem poderia ocupar. Na tentativa de se fazer reconhecer a qualquer preço, muitas vezes o jovem recorre à passagem ao ato. ${ }^{73}$.

\footnotetext{
${ }^{73}$ Passagem ao ato - ato impulsivo, que não é mediado pela representação e pelo pensamento. De acordo com Joel Birman (2006, p. 217), trata-se de uma descarga pulsional sem simbolização.
} 


\subsection{A adolescência na psicanálise}

No que diz respeito ao lugar da adolescência na psicanálise, esta ocupou por muito tempo um lugar secundário nas elaborações teóricas. Maja Perret-Catipovic e François Ladame (1997) lembram que a sexualidade infantil constituiu um dos pilares da psicanálise. Freud, em Três ensaios sobre a sexualidade (1905), apontou que a evolução libininal percorre duas etapas: a primeira, que tem como núcleo o conflito edipiano e é concluída com a resolução desse conflito e a entrada no período da latência; e a segunda etapa, que se inicia com a emergência da puberdade, se caracteriza por um período de crise, tendo como principal produto uma forma definitiva à vida sexual. Apesar da importância desse segundo tempo na evolução libidinal, a adolescência ainda se manteve num segundo plano nos estudos psicanalíticos. Uma hipótese para explicar tal fato é que o reconhecimento da sexualidade infantil era algo tão assombroso para a época, que isso contribui para deixar a puberdade na penumbra, num lugar de sombra.

Até a metade do século XX, a sexualidade infantil constitui-se em um eixo fundamental da teoria e técnica psicanalítica. A adolescência é abordada sempre em conexão com a infância e sua problemática traduz-se pela reedição e última oportunidade de resolução no decurso do desenvolvimento do conflito edipiano. Considerada dessa forma, a adolescência não acrescentaria nada de novo, sendo vista numa perspectiva genética, como algo que propicia uma finalização ao que já foi iniciado. Pelo fato de o adolescente não ser considerado nem criança e nem adulto, e por não haver um consenso sobre a forma adequada de tratar os jovens, estes não são considerados pacientes da clínica psicanalítica.

A partir da década de 1950, um impulso é dado ao desenvolvimento da teoria psicanalítica sobre a adolescência e da técnica psicanalítica com adolescentes. Segundo Lesourd (2004, p. 178), tal interesse parece decorrer de uma demanda do campo social, tendo em vista a incidência de casos de delinqüência e psicopatia entre os jovens. Nesse sentido, a questão da analisibilidade dos adolescentes toma vulto.

A primeira psicanalista a se debruçar teoricamente sobre a adolescência foi Anna Freud. Para ela, a adolescência deve ser compreendida como a etapa que corresponde ao luto da infância. A primeira psicanalista a se debruçar teoricamente sobre a adolescência foi Anna Freud. Para ela, a adolescência deve ser compreendida como a etapa que corresponde ao luto da infância. No fim da década de 1970, como afirma Kimura Bin (1983), é proposto pelo 
campo da psiquiatria o conceito de estados-limite, ${ }^{74}$ que mais tarde é absorvido pela psicanálise. Há alguns pontos comuns entre o processo da adolescência e os estados-limite, como afirmam Daniel Marcelli e Alain Braconnier (2007). Para esses autores, os adultos “limite” apresentam certos sintomas semelhantes aos sinais clínicos da adolescência, como a angústia freqüente, a tendência à depressão, o predomínio da passagem ao ato, entre outros.

No caso dos adolescentes, isso se deve às transformações corporais decorrentes da puberdade e também do desinvestimento e, posteriromente, luto dos objetos infantis, como as imagos parentais pré-edipianas e edipianas. Ainda de acordo com Marcelli e Braconnier (2007), para Otto Kenberg (1991), o estado-limite na adolescência advém das angústias referentes ao processo de separação-individuação e as relações de objeto ocupam um lugar central na sua psicogênese.

Temos aqui, resumidas, as duas posições prevalecentes da psicanálise em torno da adolescência. A primeira, que concebe a adolescência como repetição e luto da infância, e a segunda, que a descreve como segundo processo de separação e individuação.

De acordo com Jeammet e Corcos (2005), a perspectiva fundada por Anna Freud, eminentemente genética, vê a adolescência como o encerramento da infância. Nessa perspectiva, os principais elementos constitutivos da personalidade já foram adquiridos naquela etapa e a adolescência só os coloca à prova, muitas vezes, evidenciando sua fragilidade. A emergência da puberdade não parece acrescentar nada, e seu papel se restringe a organizar a passagem para a genitalidade e preparar o sujeito para a vida sexual. No entanto, do ponto de vista do desenvolvimento libidinal, a puberdade inicia depois de uma lacuna em relação às etapas anteriores, pois ela emerge após a latência, período longo que sofre a ação do recalque. Dessa forma, há o levantamento do recalque e a volta dos desejos incestuosos, desta vez, num corpo que não é mais infantil. Com a emergência do recalcado, há o retorno daquilo que provocou as fixações na infância ${ }^{75}$ e do conteúdo que ficou clivado no ego. O adolescente se vê assaltado, assim, por tais conteúdos, e pode expressá-los por via do comportamento ou da projeção. Temos aí um ponto de vista bem freudiano, baseado no complexo de Édipo.

De acordo com Catipovic e Ladame (1997), por volta da década de 1960, alguns autores acrescentam algo de novo a esse postulado. Peter Blos, nos Estados Unidos,

\footnotetext{
74 De acordo com Vera Zimermmann (2007), há outras denominações, de acordo com o autor: fronteiriços, limítrofes, borderlines. Trata-se daqueles casos que transitam entre a neurose e a psicose, embora não se enquadrem em tais classificações.

${ }^{75}$ Numa perspectiva de desenvolvimento libidinal, os pontos de fixação representam certos modos de satisfação referidos à infância, que perduram pela vida adulta. O sujeito se prende a certos objetos ou relações arcaicas.
} 
reconhece a importância do complexo de Édipo, no entanto acredita que este só é superado na adolescência, com o fim do período genital infantil. O autor se alinha a uma corrente desenvolvimentista, seguindo Ana Freud e Margareth Mahler. Apoiando-se nesta última, que descreve os primeiros anos da infância da criança e chama a atenção para a relação mãe-bebê, Blos acredita que a adolescência implica um segundo processo de separação e individuação.

Para Blos (1967), a infância e a adolescência têm em comum uma vulnerabilidade exacerbada no plano da organização da personalidade e uma urgência em realizar certos remanejamentos das estruturas psíquicas, em consonância com as demandas maturacionais. No entanto, a adolescência também traz novos elementos, mais especificamente, a necessidade de transformação e de maturação.

A adolescência ganha um estatuto próprio, sendo reconhecida como etapa que dá lugar a processos psíquicos específicos e tão importantes quanto a infância para a formação da personalidade. Essa perspectiva passa a ser conhecida como "segundo processo de separação e individuação”.

Segundo Catipovic e Ladamé (1997, p. 31), para Mahler, é importante na infância a criança internalizar o objeto primário para poder se separar da mãe, e Blos enfatiza que na adolescência é fundamental o sujeito se separar desse objeto interno para poder investir em novos objetos.

O trabalho de transformação e maturação exigido pela adolescência se dá por meio da realização de certas tarefas de desenvolvimento. De acordo com Corcos e Jeammet (2005, p. 53), elas consistiriam na “[...] integração do corpo púbere com o acabamento das identificações sexuais, autonomização e separação dos objetos parentais”. O trabalho de transformação se dá basicamente em dois níveis: no primeiro, haveria a maturação, e, no segundo nível, o desinvestimento e luto dos objetos infantis. A libido é retirada dos pais, para ser investida em novos objetos. Vale marcar que há aqui um elemento já proposto por Anna Freud (o luto), no entanto a adolescência é vista com um estatuto próprio, e não como acabamento de fases anteriores.

Jeammet e Corcos (2005) ressaltam que a simultaneidade do luto pelos antigos objetos e o investimento em novos pode ser sentida como uma ameaça pelo jovem. Isso ocorre no caso de as relações objetais internas serem ambivalentes e o deslocamento da libido para novos objetos provocar a liberação de agressividade. O luto consistiria então no trabalho 
fantasmático ${ }^{76}$ de destruir os objetos, e da emergência, por meio dos contra-investimentos, de objetos arcaicos que estavam recalcados. Por outro lado, quando não há tal ambivalência, os deslocamentos da libido representam uma abertura e um enriquecimento. Nesse sentido, os primeiros objetos são relativizados e não há a vivência da perda.

Jeammet e Corcos (2005) concordam com a perspectiva da adolescência como segundo processo de separação-individuação, no entanto ela lhes parece insuficiente para esclarecer algumas questões, como verificar o que favorece a intensidade e força às fixações infantis e a certas construções fantasmáticas. Uma tentativa de compreender isso consiste no apelo à explicação quantitativa - excesso ou falta de estímulos - no entanto, isso não lhes parece suficiente. Para Jeammet e Corcos (2005, p. 55), o conceito de força do ego parece ser elucidativo para compreender tal questão.

O conceito de força de ego é entendido aqui como produto da interrelação entre o psiquismo da criança e o ambiente. Ele resulta das interações da criança com as figuras parentais, mais especificamente a mãe, e tem em Donald Winnicott (1990) um de seus maiores estudiosos. Para o autor, a força do ego se constitui de acordo com a qualidade das interações entre o bebê e a mãe. De início, o bebê vive a experiência da ilusão, tendo a mãe só para si, atenta e provedora das suas necessidades. Progressivamente, a criança vive a desilusão, quando a mãe passa a falhar. Se esse processo é gradativo, a criança tem a oportunidade de introjetar a figura materna, de conceber os objetos como exteriores a si, e, principalmente, de constituir a crença num ambiente benigno, que não é perigoso e pode ser explorado. Tem, assim, a possibilidade de vivenciar a continuidade do ser, que é um correlato da força de ego. ${ }^{77}$

Chegando ao fim desta breve retomada sobre o lugar da adolescência na psicanálise, acreditamos que Jeammet e Corcos reconhecem as contribuições das duas perspectivas sobre a adolescência, mas seguem a tradição da escola do segundo processo de separação e individuação. Segundo Catipovic e Ladame (1997), Jeammet pode ser considerado o herdeiro de Evelyne Kestemberg, que se aprofunda sobre as vicissitudes da identificação na

\footnotetext{
${ }^{76}$ Trabalho fantasmático diz respeito ao fantasma ou fantasia. Para Laplanche e Pontalis (1985), a fantasia corresponde a um roteiro imaginário em que o sujeito está presente e que encena a realização de um desejo inconsciente, de forma relativamente deformada. Neste sentido, o trabalho fantasmático implica fazer o luto acerca dos objetos que estavam presentes na fantasia do jovem. De acordo com Pierre Kaufmann (1996), há certas fantasias fundamentais, que tratam de elementos concernentes a um mito em torno do nascimento do sujeito, da vida sexual dos pais, da forma como se constitui a sexualidade do sujeito, a diferença dos sexos e todos os temores em torno disso. No caso do trabalho fantasmático dos adolescentes, trata justamente dessas fantasias fundamentais.

${ }^{77}$ Mais à frente teremos a oportunidade de nos aprofundar sobre este tema, por meio do estudo das bases narcísicas.
} 
adolescência. Essa autora articula a problemática objetal, centrada sobre a identificação, com a problemática narcísica, que diz respeito à identidade.

Reconhecendo na adolescência uma especificidade, Jeammet e Corcos (2005) apontam que esta deve ser vista no entrecruzamento do mundo interno do sujeito e do mundo externo (o ambiente). As mudanças corporais da puberdade e suas conseqüências psicossociais são tão profundas, que levam o jovem a realizar um trabalho psíquico para buscar um equilíbrio entre essas duas instâncias.

Apesar de repousar num componente biológico, a adolescência carrega uma forte conotação cultural, uma vez que, para realizar tal trabalho, o sujeito tem de encontrar dispositivos sociais que sustentem esse processo. A sua ausência dificulta o trabalho psíquico da adolescência e parece favorecer a emergência de condutas auto e hetero-agressivas. Tais condutas expressam o fracasso do aparelho psíquico no sentido de alcançar o equilíbrio entre o mundo interno e o mundo externo (JEAMMET; CORCOS, 2005, p. 33).

Catipovic e Ladame (1997) apontam que os adolescentes continuam a sofrer por conflitos inconscientes, no entanto os conflitos que apresentam na atualidade parecem comprometer de forma intensa seu narcisismo, a possibilidade de constituir uma identidade e de experimentar o sentimento da continuidade de existência, na acepção winnicottiana. Ou seja, não parece tratar-se mais de um conflito neurótico, mas de sofrimentos advindos de patologias narcísicas.

Para Jeammet e Corcos (2005, p. 12), esses dados levam à relativização da noção de estrutura aplicada à realidade intrapsíquica. Ela é útil para o que se denomina a normalidade ou os casos extremos. Nesse sentido, preferem utilizar o termo organização psíquica, que parece ter uma conotação menos cristalizada. Os autores entendem o adolescente como um sujeito que apresenta uma organização psíquica que pode apresentar momentos de oscilação, de organização e de desorganização, assim como variados tipos de funcionamento. Nessa perspectiva, vale marcar a importância do ambiente e o papel estruturador que este pode cumprir na superação dos obstáculos que a adolescência impõe ao jovem.

Para Jeammet e Corcos (2005, p. 32), a adolescência representa uma etapa do desenvolvimento em que necessidades internas e externas exigem do aparelho psíquico um trabalho intenso de remanejamento e de elaboração que põe à prova os recursos psíquicos do sujeito, isto é, suas modalidades de organização e de funcionamento. Jeammet (2005) observa que o jovem necessita afirmar sua autonomia e, ao mesmo tempo, precisa ainda receber dos 
pais os elementos que consolidem tal aquisição - a força e a segurança interna que lhe falta. Nesse sentido, a adolescência favorece a emergência de uma tensão relacionada ao fato de que o jovem é tomado de uma contradição entre desejos opostos e geradores de um conflito interno que pode se expressar pela violência.

Dessa forma, a adolescência demanda um trabalho que se coloca em duas dimensões - somatopsíquica e simbólico-cultural. A primeira está ligada ao corpo e suas representações inconscientes, e diz respeito à transformação biológica que emerge com a puberdade, tendo seus desdobramentos na dimensão psíquica. Esta vai permitir, no futuro, a realização das relações sexuais e a possibilidade de reprodução. Já a dimensão simbólica-cultural relacionase à mudança de status social que o sujeito assume ao alcançar a fase adulta: tem acesso a uma identidade sexual adulta e pode realizar as tarefas que são naturais a essa fase, isto é, trabalho e paternidade.

Para estudar esse trabalho de grande complexidade, os autores propõem uma abordagem fenomenológica, no sentido de compreender como a subjetividade vivencia tal experiência. Na verdade, esse trabalho corresponde, no plano da personalidade, a duas “tarefas desenvolvimentistas”, segundo Jeammet e Corcos (2005, p. 38): a integração do corpo púbere e a gradativa conquista de autonomia em relação aos pais.

\subsection{A passagem do corpo infantil para o corpo adulto e suas conseqüências}

A primeira tarefa desenvolvimentista diz respeito às transformações fisiológicas da puberdade. O corpo é o lugar por excelência que sofre essa transformação, e a tarefa consiste na integração psíquica do corpo sexual púbere. Para Jeammet e Corcos (2005, p. 39), a puberdade confronta o jovem com algumas questões que exigem serem elaboradas, independentemente das suas condições e desejo: a aceitação da nova aparência corporal, a escolha da identidade sexual e a inscrição numa filiação. O corpo ocupa, assim, um lugar central na experiência do adolescente e coloca em xeque certas balizas que até então orientaram o sujeito. A primeira delas trata do poder do Eu sobre o corpo, supremacia conquistada com a fase da latência. As mudanças físicas e hormonais desestabilizam uma hierarquia a tanto custo lograda pelo sujeito. O corpo deixa de ser aquela instância que 
protege o Eu, passando a expor seus desejos, emoções, por meio dos rubores e embaraços físicos.

O corpo, até então, consistia no elemento primordial de representação que o sujeito fazia de si mesmo, era fundamental para sua identificação. No entanto, as transformações pubertárias desestabilizam a relação de continuidade entre o psiquismo e o próprio corpo. Apesar de constituir um elemento de fronteira entre a interioridade e a exterioridade, para a psique, o corpo ganha um estatuto de estrangeiro, de algo que pode lhe escapar.

Como comentam Jeammet e Corcos (2005, p. 43), o corpo é palco de transformações e superfície onde os sintomas se manifestam, acentuando a distância do Eu nesse processo. O jovem tem de se resignar a tais transformações, sendo colocado numa posição de passividade. Ante tal injunção do corpo, a reação do adolescente à condição de passividade pode ser por meio de uma conduta ativa de recusa de intercâmbio com o mundo adulto.

A passagem do corpo infantil ao corpo adulto confronta o adolescente com uma mudança fisiológica e também pulsional, ${ }^{78}$ uma vez que a puberdade surge no fim da latência. Ela propicia o levantamento do recalque infantil e a emergência de desejos reprimidos e de fantasias incestuosas (JEAMMET; CORCOS, 2005, p. 52). A relação do adolescente com os pais muda drasticamente em virtude de tais fantasias, assim a simples presença dos mesmos gera desconforto no adolescente, pois a atmosfera fica carregada de uma sexualização que é muito ameaçadora para o jovem. Isso leva à problematização do vínculo do adolescente com sua família.

Por isso Jeammet e Corcos (2005, p. 11) acreditam que o funcionamento psíquico do adolescente deve ser compreendido na articulação do mundo interno com o mundo externo. A adolescência demanda uma mudança de equilíbrio entre esses dois mundos, tanto no que diz respeito à relação com o próprio corpo e as pulsões, como em relação aos pais. Nessa perspectiva, o papel do ambiente é fundamental; ou pode funcionar como um mediador, no sentido de reforçar as bases do aparelho psíquico, ou, ao contrário, pode desestruturá-lo.

Importante marcar que o mundo externo é composto pela família nuclear e pelas instituições em geral. Os autores fazem algumas considerações sobre essa esfera que julgamos

\footnotetext{
${ }^{78}$ Referente às pulsões, que consistem em “exigências somáticas feitas à mente”, segundo Freud (1938, p.173). Em 1920, Freud elaborou a segunda teoria das pulsões, afirmando a existência das pulsões de vida, que buscam um objeto, e as pulsões de morte, que visam ao afastamento de qualquer objeto. A dualidade pulsional diz respeito ao confronto entre essas diferentes pulsões. No caso do adolescente, ele é confrontado com o desejo de ter uma relação sexual, visto que seu corpo está preparado para isso, no entanto o desejo recai sobre os objetos infantis, ou seja, a figura paterna do sexo oposto.
} 
muito oportunas à nossa pesquisa. O primeiro dado diz respeito às modificações da distância relacional e à redistribuição do espaço familiar ligadas à adolescência e às transformações da puberdade. O fato de ter um adolescente na família provoca o que Jeammet e Corcos (2005, p. 45) chamam de "adensamento da atmosfera”, isto é, a perda da naturalidade nas relações familiares e a conseqüente tensão em decorrência da necessidade de afastamento que o filho ${ }^{79}$ tem em relação aos pais.

Em virtude dos desejos incestuosos do jovem, a presença dos pais no mesmo ambiente e, sobretudo, o contato físico com estes, se torna desagradável para o sujeito, gerando grande mal-estar. O adolescente sente como se o seu espaço e sua privacidade fossem invadidos. Muitas vezes isso é motivo de conflito e da manifestação de violência por alguma das partes.

O adolescente evita a proximidade com os pais, no sentido de alcançar uma boa distância relacional, de modo a não causar constrangimentos a ninguém. Quando não é possível manter essa distância, há uma redistribuição particular do espaço; o jovem evita a convivência familiar e, sempre que possível, tenta isolar-se ou sair de casa.

Se o adolescente passa por uma revivência de desejos incestuosos, e, como afirma Anna Freud (1958), por um luto do corpo infantil, da identidade infantil e dos pais da infância, os pais também passam por certo luto, pois a adolescência do filho é um prenúncio da meia-idade.

A isso se soma a tendência de juvenilização da sociedade, como afirma Angelina Peralva (1997), em que o valor é ser jovem e envelhecer toma um caráter negativo, como se esse processo significasse uma decadência. Os pais negam esse fato, comportando-se como jovens e procurando diluir as barreiras geracionais. Assim, eles tendem a projetar-se na figura do filho, transferindo seus problemas para os do adolescente, como se este fosse um prolongamento de si próprios. Os pais evitam entrar em conflito com o jovem e querem deste uma comprovação de que são bons pais.

Há situações em que os pais se recusam a fazer o próprio luto, como no caso de Fábio, e tentam prolongar, de alguma forma, a relação infantil com o filho, o que muitas vezes chega a ser perverso, pois corrobora o desejo incestuoso do filho.

\footnotetext{
${ }^{79}$ Utilizaremos o termo "filho", no gênero masculino, porém isso vale para ambos os sexos; o mesmo faremos com o termo "jovem”.
} 
Outro fator que afeta diretamente o ambiente diz respeito às mudanças de atitudes e de comportamentos na adolescência. Na verdade, a necessidade de estabelecer uma boa distância - novos limites - em relação aos pais ou aos adultos privilegiados e a busca por um espaço mais próprio, sem a interferência de outrem, faz parte do trabalho psíquico da adolescência. Isso se reflete em suas atitudes. As pessoas que foram objeto de grande investimento afetivo na infância são, justamente, aquelas pelas quais o jovem manifesta grande ambivalência. De acordo com Jeammet e Corcos (2005, p. 46), a intensidade da ambivalência varia de acordo com a força pulsional do investimento.

E pode haver deslocamentos - o adulto que guarda alguma identidade com a figura materna ou paterna passa a ser alvo de grande oposição e até mesmo de ataques. Esse fato é muito freqüente em relação aos professores. Porém, quando está em um ambiente neutro, o jovem expressa todo o sentimento que reprime diante dos seus pais, assim pode ser afetuoso com os pais dos amigos, ou com figuras da família extensa ${ }^{80}$. Nesse sentido, o ambiente é bastante afetado por tais atitudes e muitas vezes se faz necessário diversificar as opções de convivência familiar, para não agravar tais relações.

As considerações sobre a integração psíquica do corpo púbere e a relação com o ambiente representam apenas parte do trabalho psíquico da adolescência de articulação entre mundo interno e mundo externo. A segunda tarefa desenvolvimentista, a conquista progressiva de autonomia em relação às figuras parentais, supõe a interiorização de uma relação de segurança com os pais e a aquisição de recursos internos para lidar com as diferentes tensões e conflitos. Isso remete à tese central desses autores.

\subsection{A especificidade da adolescência: entrecruzamento dos dois eixos de desenvolvimento da personalidade}

Para Jeammet e Corcos (2005, p. 60), a adolescência tem sua especificidade na medida em que nela duas vertentes de desenvolvimento se entrecruzam - a primeira se refere ao processo de interiorização, que diz respeito àquilo que o sujeito recebe e incorpora a partir de sua relação com o ambiente, principalmente as figuras paternais. A outra vertente corresponde ao processo de diferenciação ou subjetivação, pelo qual o sujeito se reconhece e se afirma em relação ao mundo

\footnotetext{
${ }^{80}$ Família ampliada, composta por avós, tios, primos, etc.
} 
externo. Essas vertentes correspondem, respectivamente, a dois eixos que percorrem o desenvolvimento da personalidade: o eixo das bases narcísicas - relações objetais, e o da dependência - autonomia. Os mesmos podem ser complementares e, em certos casos, conflitantes com a emergência da adolescência. Vamos estudar atentamente cada um deles.

\subsubsection{Eixo da constituição das bases narcísicas e das relações objetais}

Para nos aprofundarmos sobre as bases narcísicas, vamos partir da noção de narcisismo. O termo narcisismo foi utilizado por Freud a partir da figura do mito de Narciso, que fica encantado com a própria imagem. Esse termo se refere ao amor de si, ao investimento libidinal no próprio eu. Em Sobre o Narcisismo: uma Introdução (1914), Freud relata que alguns autores utilizaram esse termo anteriormente para descrever a atitude daqueles que tratam o próprio corpo como um objeto sexual e obtém satisfação do mesmo. Para eles, o narcisismo corresponderia a uma perversão, visto que tal atitude absorve a totalidade da vida sexual do sujeito.

Em seu estudo, Freud propõe que o narcisismo se afigura no desenvolvimento de todos os indivíduos. Já em 1911, na discussão do Caso de Schreber, o autor apontava a existência de uma fase do desenvolvimento sexual entre o período do auto-erotismo e o do amor de objeto, em que o sujeito toma o próprio corpo como objeto de amor. A nosso ver, uma importante contribuição da obra sobre o narcisismo parece ser a relação entre o ego e os objetos externos. Freud se aprofunda sobre a Teoria da libido, ${ }^{81}$ indicando a relação dialética entre a libido do ego e a libido dos objetos.

O desenvolvimento psicossexual inicia-se com o período do auto-erotismo, em que a criança seria cuidada por um adulto, geralmente a mãe, e teria, assim, suas primeiras experiências de satisfação. Essas experiências estão relacionadas com as funções vitais (alimentação, cuidados de higiene e proteção) e, a partir das mesmas, a criança constitui as zonas erógenas. Os pontos de contato com a mãe, que são escolhidos por ela para serem cuidados, como a boca, o ânus, a região uretro-genital e os mamilos, são erotizados e constituem pontos de satisfação sexual para a criança. O auto-erotismo consistiria, então, no ato de reinvestir os traços mnemônicos de satisfação anterior, ligados ao funcionamento de um órgão ou à excitação de uma zona erógena, somente com o fim de obter prazer,

\footnotetext{
${ }^{81}$ Freud também havia discutido sobre esse tema em Três Ensaios da sexualidade (1905).
} 
independentemente da necessidade inicial, de acordo com Jeammet e Corcos (2005, p. 59). Trata-se de uma atividade de satisfação sexual ligada a uma pulsão parcial ${ }^{82}$ e nesse estado ainda não há uma unidade no ego.

$\mathrm{Na}$ transição do auto-erotismo para o narcisismo, as pulsões sexuais, até então parciais, constituiriam uma unidade e, a partir de então, encontrariam um objeto - o ego. Isso é proposto posteriormente por Lacan, por meio da experiência do "estádio do espelho”. De acordo com Bleichmar (1991), a mãe coloca a criança diante do espelho e ele reconhece sua imagem mediante a fala da primeira. O narcisismo consistiria, assim, na captação amorosa da imagem no espelho. Ainda para Lacan, a constituição do ego como unidade psíquica é correlativa à constituição do esquema corporal.

Para Freud (1914), no narcisismo primário, a criança toma a si mesma como objeto de amor, viabilizando a primeira unificação das pulsões sexuais. Essa fase se caracteriza pela emergência de um esboço de ego e do investimento da libido neste. Vale marcar que essa etapa também corresponde à convicção da criança na onipotência dos seus pensamentos. No início, a libido se volta para a satisfação do ego e, posteriormente, torna-se independente dele.

Freud (1914, p. 94) discute então sua teoria da libido - há um investimento libidinal do ego e parte deste se desloca em direção aos objetos. Sua hipótese é de que ocorreria, desde o início, uma diferenciação da libido, num tipo que é relacionado ao ego e em outro que é ligado aos objetos. Os primeiros objetos para os quais a libido seria investida seriam os adultos que cuidam da criança, a saber, a mãe e, posteriormente, o pai. Haveria, então, uma báscula entre a libido do ego e a libido do objeto. Quanto mais uma seria investida, mais a outra diminuiria.

Freud (1914, p. 91) defende também a existência de um narcisismo contemporâneo da formação do ego, em decorrência da identificação com os objetos de amor. Trata-se de um narcisismo que implica o retorno ao ego da libido advinda dos investimentos objetais; dessa forma, essa fase corresponde a um narcisismo secundário, superposto ao narcisismo primário.

Como afirmado acima, os primeiros objetos da criança estão relacionados àquelas figuras que cuidam da criança. Freud (1914, p. 104) denomina esse tipo de escolha de objeto relação de objeto anaclítico: o objeto de amor é escolhido a partir do padrão das figuras parentais, que dão alimento, cuidado e proteção. Há outro tipo de relação de objeto, baseada

\footnotetext{
${ }^{82}$ De acordo com Laplanche e Pontalis (1985), a pulsão parcial é assim chamada, pois sua satisfação está ligada a uma zona erógena ou a objetos parciais. O auto-erotismo é definido pelo funcionamento de pulsões parciais.
} 
no próprio eu. O sujeito busca a si mesmo como objeto de amor e tal escolha corresponde à relação de objeto narcísica.

Para Freud (1914, p. 111), o desenvolvimento do ego implica o distanciamento progressivo do narcisismo primário, embora este se mantenha uma forte referência. O sujeito procura sempre retornar àquele estado. Tal distanciamento advém do investimento da libido em direção a um ideal de ego oriundo da identificação com as figuras parentais e com seus substitutos. Essa nova instância da personalidade, contemporânea à resolução do complexo de Édipo, é resultante do narcisismo (como idealização do ego) e das identificações derivadas das relações objetais. O ideal do ego, apesar de guardar traços das figuras parentais, representa um modelo a ser seguido, consistindo em substituto do narcisismo primário do sujeito, no qual ele constituía seu próprio ideal.

De acordo com Freud (1914, p. 117), assim como o ego investe no ideal do ego, ele também direciona a libido para os objetos. Parece empobrecer ao fazer tais investimentos, no entanto enriquece por meio das satisfações advindas tanto em relação aos objetos, como ao realizar seu ideal. Em outras palavras: os investimentos de objeto não suprimem os investimentos do ego, de forma que podemos concluir que o desenvolvimento da personalidade pressupõe uma balança entre esses dois tipos de direcionamento da libido. Nesse sentido, seria muito difícil imaginar um narcisismo independente das interações relacionais, da qualidade de trocas e dos investimentos objetais.

Para Jeammet e Corcos (2005), um elemento importante no desenvolvimento da personalidade, considerando o eixo do narcisismo e das relações objetais, diz respeito à heterogeneidade entre sujeito e objeto, a qual não deveria ser colocada prematuramente para a criança. A importância do ambiente, mais especificamente, dos objetos, necessitaria passar despercebida para ela. Para os autores, tal distinção pode ser gradativamente compreendida pela criança.

O psicanalista Donald W. Winnicott, membro do Middle Group, da Sociedade Britânica de Psicanálise, estuda de forma original o desenvolvimento emocional da criança e sua relação com o ambiente. Para ele, o bebê constitui de forma progressiva, sob certas condições, uma “membrana limitante” que separa o sujeito do objeto (WINNICOTT, 1990, p. 45).

Cabe esclarecer quais são essas condições. Para Winnicott (1990), nos primeiros meses de vida, mãe e bebê vivem num estado fusional, que ele denomina holding, o qual 
consiste na situação de cuidado físico e psíquico em que a mãe ou um adulto privilegiado sustenta a criança de maneira consistente. O holding ${ }^{83}$ diz respeito ao cuidado materno como expressão de amor. A mãe tem uma percepção e empatia das necessidades do bebê e respeita a sua onipotência. Apesar de viver numa condição de dependência absoluta, o bebê desconhece a existência de qualquer coisa que não seja ele mesmo (WINNICOTT, 1990, p. 48).

Todo bebê tem um potencial herdado, diz Winnicott (1990, p. 43), que é aquilo que todo ser vivo recebe em sua herança genética e esse potencial implica a tendência na direção do crescimento e do desenvolvimento. Se tal tendência é respeitada pela mãe, esse potencial pode se desenvolver gradualmente, redundando no que ele denomina “continuidade do ser”. Para o autor, a continuidade do ser constitui a base da força do ego.

No caso de haver uma falha ambiental, o bebê se preocupa com determinadas faltas (ausência da mãe, demora para ser alimentado, etc.) e deve reagir. Nessa situação, segundo Madeleine Davis e David Wallbridge (1982), a continuidade do ser é interrompida e, se a situação de adaptação do ambiente ao bebê não se restaurar rapidamente, isso equivale a um trauma. $\mathrm{O}$ fato de ter de reagir ao ambiente interrompe a experiência da continuidade do ser e leva o bebê à ameaça de aniquilamento ${ }^{84}$. Para Winniccott (1990, p. 51), o enfraquecimento do ego decorre dessa experiência.

O cuidado materno é baseado na empatia da mãe para com as necessidades do bebê, a qual advém da gravidez; inicialmente, a gestante se volta para as transformações do próprio corpo e, gradativamente, transfere o cuidado e interesse em relação a si própria para o bebê. A mãe se identifica com o filho e por isso cuida das suas necessidades em termos de holding e provisão ambiental.

Em suma, para Winnicott (1990), no holding, a mãe e o bebê constituem uma unidade. O bebê tem a vivência da ilusão, a ilusão da onipotência. Nessa experiência não há uma heterogeneidade entre sujeito e objeto. De início, a mãe provê aquilo de que o bebê necessita e dá a ilusão ao filho de que ele mesmo cria os objetos. Trata-se da "apresentação do objeto”. O bebê tem, assim, uma noção de objeto que é subjetivamente concebida. Gradativamente, o bebê vai se nutrindo dessa qualidade de troca, sem perceber a importância do objeto nesse processo. A experiência da ilusão possibilita ao bebê separar-se

\footnotetext{
${ }^{83}$ To hold - carregar, suportar, em inglês.

${ }^{84}$ Segundo Davis e Wallbridge (1982, p. 61), a ameaça de aniquilamento equivale a "uma agonia primitiva 'intensa, que ultrapassa qualquer possibilidade de descrição', antes que as defesas do ego possam se organizar contra ela”.
} 
progressivamente da mãe, concebendo-a, por fim, como "não-eu”. A partir de então, o bebê estabelece uma relação de objeto em que este é objetivamente concebido. De acordo com Davis e Wallbridge (1982), a “apresentação de objeto” facilita as primeiras relações objetais.

Articulando assim o referencial de Winnicott (1990) ao de Jeammet e Corcos (2005), podemos depreender que o amor do qual o bebê foi objeto se reflete no amor que ele dirige para si mesmo e, ainda, isso possibilita ao bebê constituir um vínculo estável com o adulto, que posteriormente pode ser ampliado para outros objetos. Sendo assim, as bases narcísicas e as relações de objeto se retroalimentam.

Como comenta Jeammet (1994, p. 5), quanto mais asseguradas estiverem essa primeira base narcísica e as interiorizações ${ }^{85}$ decorrentes das relações de objeto, tanto mais o sujeito poderá desenvolver identificações secundárias ${ }^{86}$ de forma produtiva e narcisisante numa etapa posterior. Poderá, então, se afirmar e se reconhecer, desenvolvendo o sentimento da continuidade do ser, afirmando sua subjetividade. Chegamos, assim, à segunda vertente do desenvolvimento, a da diferenciação, que pode ser problematizada por meio do eixo da dependência-autonomia.

\subsubsection{Eixo da dependência-autonomia}

Para evidenciar a complementaridade das vertentes da interiorização e da diferenciação no desenvolvimento do sujeito, vamos discutir uma situação que põe à prova os elementos adquiridos no processo de constituição das bases narcísicas e relações objetais, e, ao mesmo tempo, introduz o eixo da dependência-autonomia: a experiência de separação.

Tomando como exemplo a situação da criança de 18 meses que vai dormir e se confronta com a solidão, Jeammet e Corcos (2005, p. 56) descrevem três possibilidades. A primeira é a da criança que se vê sozinha e recorre aos seus recursos internos para suprir a falta da mãe. Lança mão dos auto-erotismos: suga o polegar, recorre à rememoração de situações prazerosas e acaba por se tranqüilizar. O funcionamento psíquico substitui a mãe e os demais objetos de amor. De acordo com Jeammet (1994, p. 5) e John Bowlby (2001, p.

\footnotetext{
${ }^{85}$ A interiorização trata do movimento de trazer para o mundo interno certas relações intersubjetivas com os objetos de amor; assim, por ocasião da resolução do complexo de Édipo, o sujeito introjeta a imago paterna e interioriza a relação de autoridade em relação ao pai.

${ }^{86}$ As identificações primárias implicam um estado em que sujeito e objeto ainda não se diferenciaram; neste sentido, ainda não se estabeleceu uma relação de objeto propriamente dita. Já no caso das identificações secundárias, esse processo já se efetivou.
} 
175), a interiorização dos laços afetivos propicia ao bebê liberdade e segurança que lhe permitem explorar o mundo externo e a si mesmo sem temores.

No segundo caso, a criança chora ao ver-se sozinha. Fica fragilizada e necessita da presença física da mãe. A mãe volta e sua presença possibilita ao bebê recuperar o equilíbrio interno e a segurança. A partir de então, a criança faz uso dos seus recursos psíquicos. Vemos então a dependência de um apoio exterior, o que indica certa vulnerabilidade, pois, diante da ausência desse suporte, o bebê corre o risco de desorganização e de não conseguir utilizar seus próprios recursos.

No terceiro caso, a criança se depara com a solidão e sente tamanho desamparo e insuficiência de recursos internos, que recorre ao que os autores denominam auto-estimulação do corpo, como arrancar os próprios cabelos, fazer movimentos corporais estereotipados. Neste caso, a auto-estimulação dolorosa dá à criança a sensação de que existe, está viva.

Em suma, para Jeammet e Corcos (2005, p. 56), no desenvolvimento da personalidade há um jogo dialético entre os investimentos e os contra-investimentos em relação aos objetos de amor (os pais), entre a interiorização das relações intersubjetivas e o super-investimento defensivo na realidade perceptivo-motora, isto é, a necessidade de ter a presença dos objetos de amor, e por fim, entre o recurso à satisfação alucinatória do desejo (os auto-erotismos) e o apoio sobre o mundo das percepções e das sensações.

Portanto, retomando a balança entre o narcisismo e as relações de objeto, podemos depreender a necessidade de que a criança possa constituir de forma gradual a tal membrana limitante entre o mundo externo e o mundo interno. Dessa forma, ela pode viver a continuidade do ser, que é experimentada como força do ego.

Vale abrir um parêntese e trazer uma idéia correlata de força de ego. Para Winnicott (1990, p. 160), o conceito de força do ego também se refere à posição depressiva, formulada por Melanie Klein. A posição depressiva diz respeito à integração, para o bebê, da mãe como objeto completo. Antes, ele a apreendia de forma parcial - ora como o bom objeto, e ora como o mau. Quando a criança conquista a posição depressiva, as pulsões libidinais e hostis passam a referir-se ao mesmo objeto.

Como fala Winnicott (1990), a criança admite as idéias agressivas em si, quando pode associá-las a idéias reparadoras. Sendo assim, a criança percebe que nada é definitivo e que esses dois sentimentos fazem parte da vida e podem ser dirigidos à mesma pessoa. Vale assinalar que isso só é possível mediante a presença continuada do objeto de amor - a mãe -, 
caso contrário, a criança não teria a oportunidade de fazer a reparação. A conquista da posição depressiva tem como correlatos a organização e a força do ego.

Voltando ao tema da interação mãe e bebê, quando a heterogeneidade é colocada prematuramente pelo ambiente, em vez de vivenciar a onipotência, a criança experimenta justamente o oposto. Vive a impotência, sentida como ausência de recursos para lidar com as demandas externas, além da dependência em relação aos apoios externos. Isso corresponde a um antagonismo entre as bases narcísicas e as relações objetais.

Tal antagonismo pode ter conseqüências drásticas para a criança, que pode levar à psicose ou autismo, como vimos no terceiro caso de separação. No geral, coloca sérios obstáculos ao processo que se inicia na infância e tem seu ponto alto na adolescência - a conquista da autonomia.

Além da qualidade das bases narcísicas, um elemento fundamental na conquista da autonomia do sujeito e de sua contenção dos conflitos intrapsíquicos é a diferenciação interna do aparelho psíquico. Quando essa diferenciação não se efetivou de forma satisfatória, o sujeito fica mais vulnerável para responder às variações do mundo externo. Vale lembrar que são as bases narcísicas que sustentam essas diferenciações.

Na Interpretação dos sonhos (1900), Freud descreveu o aparelho psíquico segundo uma constituição tópica, configurado por lugares psíquicos, o que implica uma heterogeneidade entre eles e a especialização de cada um. Esses lugares correspondem a sistemas diferentes - o Inconsciente, o Pré-consciente e o Consciente ${ }^{87}$ - cada um com um tipo de processo e de investimento, de maneira que a diferenciação tem um valor funcional. Desde o início, Freud propõe uma concepção dinâmica, tendo em vista o conflito dos sistemas ente si: a psique sempre se depara com exigências internas contrárias.

De acordo com Laplanche e Pontalis (1985), na segunda tópica, anunciada em $O$ ego e o id (1923), Freud reformula sua proposição inicial, pois reconhece que no ego também haveria os mecanismos inconscientes de defesa. Conclui que não haveria uma coincidência entre os conteúdos e os sistemas, ou seja, o recalcado não se restringiria somente ao Inconsciente e o ego ao sistema Pré-consciente-Consciente. Além disso, Freud descobre o papel das diversas identificações na constituição do sujeito. Para ele, os efeitos das primeiras identificações efetuadas na infância serão gerais e duradouras, são responsáveis pelas

\footnotetext{
${ }^{87}$ Essa divisão ficou conhecida como a primeira tópica.
} 
formações permanentes que constituem as instâncias psíquicas (ideais, críticas, imagens de si mesmo).

Haveria também outro motivo para a criação da segunda tópica, como comenta André Green (2005). No modelo proposto pela primeira tópica, as pulsões não faziam parte do aparelho psíquico, já que elas não eram consideradas nem conscientes e nem inconscientes. A partir da segunda tópica, Freud propõe que o id seja o reservatório das pulsões. Sendo assim, elas passam a fazer parte do aparelho psíquico.

Na segunda tópica, Freud propõe três instâncias psíquicas: o id, o ego, e o superego. Além de reformular o funcionamento entre as instâncias, ele propõe uma diferenciação no interior de cada sistema e defende não só a idéia de relações intersistêmicas, como também, de relações intrassistêmicas.

Para Jeammet e Corcos (2005, p. 60), tal diferenciação tem por fim a criação de um espaço de jogo intrapsíquico para lidar com os afetos e representações. Deslocamentos sucessivos operam certas diferenças e aliviam o funcionamento psíquico, evitando, dessa forma, uma reação explosiva.

Um exemplo disso se refere ao recurso do "teste de realidade". Em $O$ ego e o id (1923, p. 72), Freud afirma que ego teria três senhores: o mundo externo, a libido do id e a severidade do superego. Diante de um conflito entre o id e o mundo externo, mais especificamente, quando há uma confusão do id ao nível da percepção em relação a uma representação advinda do mundo externo, o ego recorre ao dispositivo do teste de realidade, no sentido de excluir tudo o que for um acréscimo decorrente de fontes de excitação do id, interpondo assim os processos de pensamento, como forma de evitar uma descarga motora.

A diferenciação psíquica é contemporânea ao atravessamento do Édipo, tendo como herdeiros o Ego, Id, Superego, objeto do desejo, o Ideal de Ego e as imagos parentais. A resolução edipiana tem efeitos sobre a estruturação do sujeito, justamente sob a forma de identificações. Os investimentos nas figuras primordiais são abandonados e substituídos por identificações, as quais servem de suporte para a diferenciação das instâncias intrapsíquicas ${ }^{88}$.

Quando esse processo chega a termo, a criança adquire, então, uma contenção, uma possibilidade de enfrentar, desde o mundo interno, as pressões externas. Faz uso dos processos mentais para lidar com os conflitos, pois constituiu internamente recursos para

\footnotetext{
${ }^{88}$ Por instância intrapsíquica entende-se as partes ou elementos que compõem as instâncias psíquicas, como o ideal de ego, as imagos parentais, etc.
} 
elaborar simbolicamente as variações do ambiente. Não depende tanto dos apoios externos e pode avançar na progressiva afirmação de si.

\subsection{A adolescência e o risco do antagonismo dos eixos de desenvolvimento da personalidade}

A psicanálise mostra que o desenvolvimento da personalidade apresenta um paradoxo de difícil solução para o sujeito, sobretudo para o jovem. A travessia da adolescência implica a constituição da subjetividade sobre novas bases, diferente daquelas constituídas no seio da família, porém, para poder se diferenciar, o jovem necessita das referências primárias.

A questão da subjetivação parece constituir um prolongamento da experiência da continuidade do ser, proposta por Winnicott (1990). Ela possibilita a afirmação de si, ao mesmo tempo em que reafirma a diferença em relação ao outro. O jovem necessita do outro para constituir sua personalidade, mas, se ele se aproxima demais do adulto, sente-se ameaçado, pois a adolescência apresenta um impacto na economia psíquica referente às mudanças fisiológicas operadas pela puberdade.

Como já foi afirmado, tais mudanças exigem do jovem um processo de integração psíquica do corpo transformado - reconhecer que está apto a realizar a sexualidade genital e a procriar - porém, tem de equacionar seus desejos com a realidade. A nova demanda pulsional leva o adolescente à revivência do conflito edipiano e, com ela, à defrontação com seus desejos incestuosos.

A aproximação em relação aos pais ou adultos privilegiados, que seria tão necessária para realizar suas identificações, torna-se perigosa. Para Jeammet (1994, p. 12), na adolescência todo objeto investido pode tornar-se uma fonte de excitação e corre o risco de perder seu uso como apoio narcisista.

Dessa forma, os dois elementos que constituem o eixo das bases narcísicas e das relações objetais, que deveriam funcionar numa relação de báscula, com a emergência da puberdade, são experimentados pelo sujeito como se fossem antagônicos.

O antagonismo entre as bases narcísicas e as relações objetais pode resultar em duas conseqüências, segundo Jeammet e Corcos (2005, p. 61): a primeira incide sobre o 
desenvolvimento da personalidade, dificultando as trocas e a interiorização, bases para os mecanismos de identificações. A segunda conseqüência incide sobre o desenvolvimento mental, obstruindo as possibilidades de representação. Sendo assim, as variações do ambiente não podem ser elaboradas simbolicamente, uma vez que não passaram pelo processo de representação.

Como afirmamos anteriormente, a conjunção das duas vertentes do desenvolvimento e a pressão destas sobre o sujeito marcam a especificidade da adolescência. Para Jeammet e Corcos (2005, p. 62), a intensidade de uma vertente pode levar à contraposição com a outra. As falhas narcísicas sexualizam as relações, ao passo que o maior investimento objetal evidencia a importância dos objetos de amor, gerando no jovem o sentimento de dependência em relação aos pais.

Para os autores, a adolescência questiona o jovem em relação a duas questões: o complexo de Édipo e o narcisismo. Mais ainda - o sujeito deve posicionar-se em relação aos mesmos. Isso se torna particularmente difícil, pois o adolescente ainda não encontrou apoios narcísicos para além das figuras paternas, visto que se encontra num momento ainda inicial da vida social. Não dispõe ainda de formas alternativas de reconhecimento como os adultos, que os têm por meio do trabalho ou de um relacionamento conjugal.

Fazendo um balanço dos dois eixos do desenvolvimento da personalidade, no sentido de compreender a problemática adolescente, Jeammet e Corcos (20005, p. 62) afirmam que é a qualidade dos vínculos estabelecidos na primeira infância com os objetos de amor que propiciam a interiorização e a constituição dos auto-erotismos. A relação com o objeto de amor é interiorizada sob a forma do “objeto interno bom”.

Diz Winnicott (1990, p. 34) que a interiorização desse objeto propicia à criança autosuficiência para viver, até na ausência de objetos externos; ela adquire confiança no presente e no futuro. Essa confiança se constitui por meio da repetição de satisfações instintivas. Caso contrário, como vimos na experiência de separação, quando não há a adaptação do objeto externo às necessidades da criança, ela não interioriza o sentimento de segurança e recorre ao super-investimento em relação aos objetos externos.

Para Jeammet e Corcos (2005, p. 63), a qualidade das relações objetais, em última análise, seria a responsável pela qualidade libidinal dos investimentos de que o sujeito lança mão. Isto passa pelo processo de interiorização do objeto bom, pela via dos auto-erotismos, e depois pela via das identificações. Mais especificamente, os auto-erotismos constituem as 
bases narcísicas do sujeito, e as identificações funcionam como sustentação para a diferenciação das estruturas intrapsíquicas. Assim, quanto mais o sujeito tem imagos diferenciadas internalizadas, mais se diferenciam o Superego e o Id, e menos o sujeito necessita investir massivamente os objetos, o que poderia ser ameaçador para as bases narcísicas. Na situação oposta, quanto mais o sujeito investe os objetos, mais as respostas podem ser percebidas como ameaçadoras para os seus limites, e a reação do jovem, por sua vez, pode ser violenta.

Nesse sentido, quando há um aumento de estímulo, e os recursos do ego são insuficientes para responder ao mesmo, isto tem como efeito o trauma, levando a uma indiscriminação entre o mundo interno e mundo externo, ou entre as estruturas intrapsíquicas. Quando essas referências internas são abaladas, as representações perturbam o ego, e este, como único recurso, recorre ao agarramento à realidade perceptiva, no sentido de fazer uma discriminação entre o dentro e o fora. Outro fator que pode ser desestruturador para o jovem é a constante demanda por uma regressão ao passado. Isso é próprio da situação de dependência, ou também, em virtude da emergência dos impulsos incestuosos, decorrentes da emergência da puberdade.

\subsection{A problemática da dependência na adolescência}

Para os autores, a sensação constante do ego adolescente seria a do temor de ser invadido e de perder o controle diante das situações. Isso se expressa de diferentes maneiras, tanto externamente, pela manifestação de rubores, como internamente (com o que parece até mais difícil de lidar) como a emergência de desejos contraditórios, a irrupção de impulsos destrutivos e até mesmo o temor de enlouquecer.

Nesse sentido, como afirmam Jeammet e Corcos (2005, p. 64), é fundamental o equilíbrio entre as bases narcísicas e a necessidade do apoio no mundo externo perceptivomotor. Quando não há tal estabilidade, o equilíbrio narcísico recai sobre os objetos de amor: as figuras parentais, as quais têm a função de contra-investimento defensivo de uma realidade interna que é ameaçadora para o sujeito.

Davis e Wallbridge (1982) afirmam que o suporte do ambiente, na forma de um apoio egóico, corresponde a uma necessidade da criança, do adolescente e até mesmo do adulto, sempre que há uma pressão que coloca em risco o equilíbrio interno. O problema, a 
nosso ver, é quando o adolescente é excessivamente dependente das figuras parentais para assegurar tal estabilidade.

Como vimos, o sentimento de continuidade de si depende da interiorização de objetos internos bons. Quando estes não bastam para assegurar o sujeito, ele mantém relações de objetos idealizadas. ${ }^{89}$ Esses vínculos são particularmente conflitantes na adolescência, pois a sexualização das relações e a desidealização dos objetos de amor, próprias dessa etapa, fazem com que as figuras parentais percam seu papel de suporte narcísico. O processo de autonomização pressupõe tal desinvestimento. Como diz José Outeiral:

(...) uma das tarefas centrais da adolescência é a 'independização'. Esta, é necessário deixar claro, não é uma ruptura com a família, mas sim a transformação de vínculos infantis de relacionamento por um outro tipo de vínculo mais maduro, mais independente e de maior tolerância (menos idealização) com os pais. (2003, p. 12)

No entanto, a autonomia só pode ser conquistada por aqueles que completaram suas identificações e se asseguraram de seus recursos internos, e isso se dá mediante o vínculo de dependência. Ou seja, para aqueles que ainda dependem das figuras parentais, atualiza-se o antagonismo entre necessidade objetal e autonomia do sujeito, pois o adolescente, que desejava distanciar-se daqueles adultos, tem de aceitar a dependência em relação a tais figuras.

A partir dos relatos de caso de Fábio e Otto, poderíamos levantar a hipótese de que o recurso à dependência em relação às figuras parentais poderia ser um pedido aos adultos para assumirem a diferença geracional em relação ao filho e, no lugar de adultos, propiciarem o suporte necessário ao desenvolvimento do jovem. Esse pedido não significa que o jovem se manterá dependente, ao contrário, pode representar uma possibilidade de o jovem concluir certos processos psíquicos que ainda estão pendentes.

A manutenção do vínculo de dependência deve ser analisada considerando-se os dois lados da questão - o do adolescente e do ambiente. O relevo dado por Jeammet e Corcos (2005) recai sobre o adolescente, tendo em vista as transformações da puberdade e o trabalho subjetivo que o jovem deve realizar. No entanto, os autores reconhecem que o ambiente pode favorecer tal dependência, por ocasião do desenvolvimento emocional primitivo. No caso de haver separações bruscas, elas podem impedir a experiência da continuidade do ser, o que

${ }^{89}$ Para Laplanche e Pontalis (1985), a idealização consiste na hipervalorização das qualidades e do valor do objeto. Esse processo psíquico é necessário por ocasião da constituição das instâncias ideais, como o ideal do ego. 
reforça a necessidade do suporte do ambiente. O abandono da mãe de Otto pode ter representado tal quebra na experiência de continuidade de si.

Outras vezes o padrão de dependência já vem como herança dos próprios pais. O pai de Otto, em sua juventude, ao assumir o namoro com a primeira mulher, pareceu necessitar de um amparo dos próprios pais. É como se ele não tivesse autonomia para construir um relacionamento a dois, menos ainda para se tornar pai. Tanto é que abdicou dessa função em favor dos pais, após a separação. Queremos com isso assinalar que sua entrada no mundo dos adultos foi marcada pela demanda de amparo aos pais. Os autores afirmam que muitas vezes são os próprios pais que não conseguem favorecer a autonomia do filho. Houve, nesse caso, uma complementaridade entre o pai de Otto e de seus pais nesse processo. Prova disso é que a avó continuava a exercer o papel materno de um adolescente, sendo já uma pessoa idosa.

Como já foi apontado, o contexto cultural da contemporaneidade e a valorização da juventude acabam por diluir as barreiras geracionais. Jeammet e Corcos (2005, p. 65) observam que os pais, muitas vezes, se expõem demasiadamente em relação aos filhos, criando uma proximidade que acaba por intensificar a sexualização dos vínculos e a desidealização das relações.

De fato, nos casos de Fábio e Otto, poderíamos afirmar que os pais falham ao não marcarem a diferença geracional em relação ao filho e, como iguais, não propiciam o suporte necessário ao jovem para constituir recursos internos que sejam suficientes para lidar com os conflitos que emergem por ocasião da adolescência. Assim, podemos considerar que a manutenção de um vínculo de dependência entre o jovem e os pais pode advir de falhas no ambiente, ocorridas no desenvolvimento primitivo da criança. Também podemos perceber as falhas do ambiente numa etapa posterior, já na própria adolescência, quando os pais não respeitam a necessidade de uma distância relacional e não estabelecem as barreiras geracionais em relação ao filho.

A relação de dependência pode assumir diferentes significados para cada jovem. De acordo com as trocas que se estabelecem entre o adolescente e o ambiente, muitos destinos podem se traçar. Há aqueles que retomam um intercâmbio narcísico com os objetos de amor, fazendo o acabamento das identificações. Nesse caso, fazem um uso criativo do estado de dependência, viabilizando a conquista da autonomia. Outros podem se enredar na dependência. De acordo com Jeammet (1994), a diversidade de destinos pode estar relacionada às respostas do ambiente, no sentido de auxiliar o jovem em sua organização psíquica ou não. 
Há adolescentes que lutam contra a dependência por meio de atitudes auto ou heteroagressivas. Eles tendem a se defender da realidade psíquica falha ou ameaçadora, utilizando o recurso da realidade perceptivo-motora. Isso diz respeito ao campo das atitudes concretas e do comportamento, sem a mediação da palavra, como as passagens ao ato. Vale lembrar que essas atitudes se opõem à capacidade associativa ${ }^{90}$, à elaboração, porém, como foi afirmado anteriormente, a própria possibilidade de desenvolvimento mental fica prejudicada pelo antagonismo das bases narcísicas e das relações objetais. A ameaça à autonomia e ao pensamento é sentida como uma violência para o narcisismo do jovem e ele responde à situação de dependência pelo agir, como forma de marcar os limites entre mundo interno e mundo externo.

É importante assinalar que, o agir, conforme Jeammet (1994, p. 11), defronta o sujeito com uma dialética muito particular entre a espacialidade e a temporalidade. $\mathrm{O}$ adulto costuma se dirigir ao jovem com base na temporalidade, no sentido de solicitar a este que tenha paciência e aguarde os efeitos do tempo sobre sua vida, seu corpo e suas disposições. Trata-se de uma confrontação com a passividade, e a isso o adolescente tende a responder pelo uso do espaço, ou seja, do agir. Parece uma tentativa de buscar um controle no espaço de algo que não se controla em relação ao tempo. Essa exigência dos pais, em geral, pode parecer muito regressiva, remetendo o jovem à infância, quando era necessário aguardar até o momento de virar adulto. Agora o adolescente já tem um corpo quase adulto, assim não lhe parece fazer sentido ter de se submeter ainda mais uma vez a Cronos.

Como vimos, o recurso do agir e do comportamento tem a função de diferenciar o mundo interno do mundo externo. De acordo com Jeammet (1994, p. 4), o sujeito recorre a um trabalho de expulsão e de busca de controle no mundo exterior daquilo que não pôde ser contido e controlado no mundo interno. Daí o termo patologia do agir.

Por patologia do agir, Jeammet (1994, p. 3) entende os transtornos do comportamento que têm uma singularidade na economia psíquica do sujeito e, também, o fato de colocarem em risco os jovens que a manifestam. Podemos dar como exemplo condutas aditivas, distúrbios de comportamento alimentar (bulimia e anorexia), cortes na pele, passagens ao ato, tentativas de suicídio, fugas, condutas sociopatas e certas formas de recusa

\footnotetext{
${ }^{90}$ Veremos, mais à frente, que o estabelecimento de laços associativos é próprio do funcionamento do princípio do prazer-realidade. A instauração deste corresponde a diversas adaptações no aparelho psíquico, que se vê na iminência de desenvolver as funções conscientes, como a memória, a atenção, o juízo e, sobretudo, a substituição da motricidade pelo pensamento.
} 
escolar. Poderíamos afirmar que essas patologias têm algo em comum: a manifestação de uma recusa ao intercâmbio com o mundo adulto.

Analisando a questão da dependência, Jeammet e Corcos (2005) comentam que ela representa uma constante no desenvolvimento da personalidade, pois há, do ponto de vista do funcionamento mental, uma dialética entre investimento e contra-investimento entre a realidade interna e a realidade externa do mundo perceptivo-motor. A dependência toma relevo na adolescência, na medida em que representa o modo de funcionamento prevalecente, em prejuízo de outros.

A adolescência, examinada dentro do quadro da organização psíquica e das várias modalidades de funcionamento, como o proposto pelos autores, comporta o vínculo de dependência em diferentes conjunturas. A dependência pode constituir, assim, um modo de funcionamento transitório, necessário ao equilíbrio entre o mundo interno e externo. Tornamse dependentes os jovens que recorrem de modo preferencial ao mundo da realidade externa, no sentido de se defender de uma realidade interna ameaçadora. Eles recorrem a isso, pois não dispõem da segurança interna para lidar com os conflitos e desafios que a autonomia implica. Ao contrário, quando o sujeito dispõe de recursos internos e por ventura se depara com algum conflito, a necessidade de depender e de regredir não provoca uma desestabilização psíquica.

No caso de jovens que ficam enredados no vínculo de dependência, Jeammet e Corcos (2005, p. 128) propõem como forma de intervenção a terapia bi-focal. Trata-se de uma abordagem que procura evitar a polarização do vínculo terapêutico, não colocar todas as demandas sobre um só trabalho, para proteger a relação e não dar a impressão ao adolescente de que se trata de algo ameaçador (como lhe parece o vínculo com os pais).

$\mathrm{Na}$ terapia bi-focal, um terapeuta, geralmente um psiquiatra, se incumbe do mundo externo do sujeito: seus sintomas, sua família, sua vida escolar. Ele coordena o trabalho, conversa com os pais, com os demais terapeutas e também faz os encaminhamentos necessários. O outro terapeuta cuida do mundo interno do sujeito; ele se desincumbe das preocupações relativas ao sintoma. Neste caso, como comenta Jeammet (1994, p. 10), o terapeuta funciona como um objeto de apoio que pode se adaptar às necessidades do sujeito, no sentido apontado por Winnicott (1990), de forma a reestabelecer o equilíbrio entre investimento de objeto e salvaguarda narcísica. Dessa maneira, o adolescente teria uma nova chance de estabelecer uma relação de objeto menos excitante e encontrar o apoio narcísico necessário, além de realizar um trabalho de elaboração. 
A terapia bi ou multifocal procura proteger os vínculos do sujeito com cada terapeuta e, ao mesmo tempo, é uma forma de não sobrecarregar a tarefa de cada um. Seria difícil para o terapeuta restabelecer o sentimento de continuidade de si junto ao sujeito e, ao mesmo tempo, responder aos pais frente a cada deslize do adolescente. E, no caso do médico, muitas vezes ele faz indicações que, no entender do jovem, vão contra seus desejos. Esse modelo de atendimento é oferecido pelo Instituto Mutualiste Montsouris, em Paris, cuja equipe é integrada por Jeammet e Corcos, sendo dirigida por Jeammet.

Em relação aos problemas escolares do jovem, os autores acreditam que medidas educativas ou pedagógicas podem ser complementares ao procedimento terapêutico descrito acima. Esse trabalho teria como função oferecer um espaço transicional, como propõe Winnicott. Nas palavras de Jeammet e Corcos:

(...) um espaço de encontro onde se pode desenvolver um clima de intercâmbios e de prazeres compartilhados, sem serem sexualizados e excitantes, ou seja, sem que o adolescente tenha de tomar claramente consciência desses prazeres e, sobretudo, sem que ele precise se questionar sobre a proveniência, o papel e o lugar do outro em seu desenvolvimento. A finalidade desse "fazer adolescente" é restaurar um prazer não mais autárquico, mas um funcionamento bastante extenso, que se apóia sobre o objeto do modo menos conflitante possível. (2005, p. 125)

Acredito que esse “fazer adolescente” é mais do que necessário para os jovens que parecem ter desinvestido a aprendizagem escolar. É sobre isso que vamos discutir no próximo capítulo. Vou investigar uma forma peculiar de o adolescente lidar com a dependência. Ela consiste no ataque ou no distanciamento dos objetos que dizem respeito a uma parte dos investimentos e potencialidades do próprio sujeito. $\mathrm{O}$ ataque recai sobre as figuras parentais e igualmente sobre o adolescente, o que se dá mediante o boicote sobre um talento, um interesse que até então ocuparam grande parte da vida do jovem, como a aprendizagem. Trata-se da recusa escolar. 


\section{A recusa escolar}

Muitos adolescentes que fracassam na escola fogem dos moldes do problema de aprendizagem tal como se conhece entre as crianças. Trata-se de jovens que, no primeiro ciclo do Ensino Fundamental, não manifestaram dificuldades de aprendizagem, no entanto, a partir da puberdade, ou até mais tarde, apresentam problemas de fracasso escolar. De forma geral, no caso dos adolescentes, o fracasso ocorre em contextos de ritos iniciáticos, em momentos de transição de um contexto protegido para uma situação em que se exige mais autonomia. É sabido que em nossa sociedade não há mais ritos de passagem, que marquem um novo lugar a ser ocupado pelos adolescentes. A escola parece representar um dos únicos espaços que oferecem “provações” aos adolescentes. Assim, alguns jovens passam a apresentar dificuldades na passagem do primeiro ciclo para o segundo ciclo do Ensino Fundamental, outros na transição do Ensino Fundamental para o Ensino Médio e outros, ainda, na época do vestibular.

O fracasso escolar parece aí estar relacionado à perda do interesse pelo conhecimento e pela integração escolar. É o que aconteceu com Fábio e Otto. Ambos apresentaram dificuldades com o conteúdo escolar, e, sobretudo, problemas disciplinares, por volta da metade da $5^{\text {a }}$ série (atual $6^{\circ}$ do EF). É como se houvessem retirado todo o investimento libidinal que antes era dirigido para a aprendizagem e para as trocas sociais oferecidas pela escola. Vale marcar que não se trata aqui daquilo a que François Dubet e Danilo Martuccelli (1996) se referem como resultante da concorrência com a cultura juvenil, quando o interesse pela cultura escolar é transferido para a cultura juvenil. Nos casos em questão, eles simplesmente se recusaram a interagir com a escola e não colocaram nada em seu lugar.

Para Philippe Jeammet (2002), esse tipo de comportamento parece guardar uma semelhança com alguns transtornos de comportamento próprios da adolescência, como as patologias do agir, pois estas implicam um recuo do sujeito na interação com o meio e na retirada dos investimentos em certos elementos que até então constituíam objetos de interesse do jovem. Segundo o autor, são condutas que poderiam ser qualificadas de "passividade ativa” e caracterizam os jovens que se desconectam progressivamente dos objetos de interesse, de toda produção (intelectual, artística, esportiva, etc.), assim como das relações afetivas, levando-os a certo isolamento domiciliar. 
O fracasso escolar na adolescência teria, então, para Jeammet (2000), uma relação com as patologias do agir, pois, como estas, ele se expressa no plano da motricidade, do comportamento, sendo acompanhado pela impossibilidade de representação e de expressão mental do conflito intrapsíquico subjacente, o que quer dizer que o sujeito não tem a possibilidade de solicitar uma ajuda: apenas pela atuação essa demanda é expressa.

Outro ponto em comum entre o fracasso escolar e as patologias de agir diz respeito ao caráter de auto-sabotagem das potencialidades do sujeito, podendo atingir o corpo, as possibilidades de investimento afetivo e relacional ou a capacidade de aprendizagem. Em outras palavras, o jovem deixa de investir em algo que lhe interessa e lhe dá prazer. Tal investimento, até então, representava uma possibilidade de fruição cultural, propiciando uma identidade ao adolescente, além de constituir uma forma de reconhecimento pelo ambiente.

Procurando compreender os elementos que subjazem à aprendizagem e que podem ter uma ressonância na passagem da adolescência, o autor lembra que a aprendizagem comporta duas dimensões - a dimensão pulsional e a dimensão da separação. No que diz respeito à primeira dimensão, a aprendizagem, como mostra a psicanálise, não é neutra no plano afetivo. Esta dimensão está na base dos investimentos, motivações e interesses do sujeito. A base pulsional é composta pelas pulsões de vida e pulsões de morte, isto é, entre a libido e a agressividade, respectivamente. Para Freud (1938a), essas pulsões podem atuar em direções divergentes ou convergentes nos mais variados momentos da vida. Nesse sentido, dois movimentos estão presentes no ato de aprender: o da atração pelo objeto de conhecimento, ligado ao prazer, e o movimento de fazer uso da própria agressividade para se apropriar desse objeto, de tomá-lo para si. Esse movimento está associado à interiorização.

Freud (1938a) utilizou o modelo da ingestão oral para discutir a dualidade pulsional, as pulsões de vida e de morte ${ }^{91}$. Para ele, o ato de comer implica a destruição do alimento, com o objetivo final de incorporá-lo. Jeammet (2002, p. 3) acrescenta: todo ser humano necessita de algo que lhe é externo para se nutrir. Para o corpo se desenvolver, é necessário alimentar-se de algo que vem do mundo externo, e o mesmo se passa no nível psíquico. A introjeção de objetos externos e a interiorização das relações intersubjetivas constituem as bases das identificações do sujeito.

\footnotetext{
${ }^{91}$ Da forma como entende Renato Mezan (2002, p. 367), o conceito de pulsão diz respeito à relação de objeto. Assim, a pulsão de vida visa a investir no objeto e a pulsão de morte busca o afastamento ou a destruição do objeto.
} 
A aprendizagem se dá pela oscilação entre os pólos da agressividade e do prazer. Assim, o sujeito faz uso de um tanto de agressividade para incorporar o objeto de conhecimento, e para manter essa atividade, é necessário que ela proporcione certo prazer ao indivíduo. O problema surge quando essa oscilação pende para alguns dos lados. O excesso de agressividade na aprendizagem pode gerar um medo do potencial destruidor do sujeito, levando a uma retração, à inibição da capacidade intelectiva. E o excesso de prazer pode resultar na angústia de entrar em um processo de alienação em relação ao objeto ou no temor de ser invadido pelo mesmo, de ele tomar conta de todas as esferas da vida do sujeito.

Além da dimensão pulsional, há também a dimensão da separação compreendida na aprendizagem. O sujeito que aprende deve reconhecer que o objeto de conhecimento é externo e que ele necessita desse objeto e o deseja, tendo de se resignar às próprias limitações; aquilo que o sujeito deseja não está sob o seu poder e é algo separado dele, podendo ser em parte adquirido, mas também perdido. A dimensão da separação na aprendizagem diz respeito à confrontação com a solidão e com o fato de não ser auto-suficiente. Tal confrontação muitas vezes pode ser sentida como excessiva para o sujeito, gerando angústia de separação e impotência diante do novo, do desconhecido. ${ }^{92}$

Pois bem, tanto a dimensão pulsional como a dimensão da separação parecem ser particularmente convocadas pelo aparelho psíquico por ocasião da emergência da puberdade. Esta põe em marcha um processo longo e árduo, que corresponde às ditas tarefas desenvolvimentistas, segundo Jeammet e Corcos (2005): a integração do corpo púbere e a gradativa conquista de autonomia em relação aos pais.

Para Jeammet (2002), o fracasso escolar nos adolescentes parece revelar a impossibilidade de representação e de expressão mental do conflito intrapsíquico decorrente das transformações da puberdade. O jovem, diante da impossibilidade de elaborar tal conflito, atua por meio da recusa ao intercâmbio e da auto-sabotagem. Por esse motivo, vamos utilizar o termo recusa escolar, ${ }^{93}$ também utilizado por Jeammet e Corcos (2005, p. 31). Acreditamos

\footnotetext{
${ }^{92}$ Nestas situações, é importante a presença de um terceiro para tranqüilizar o sujeito, no sentido de ajudá-lo a sustentar esse momento árduo da aprendizagem. Essa é uma das tarefas do psicopedagogo.

${ }^{93}$ Vale assinalar que recusa escolar difere de "recusa ansiosa da escola", termo substituto para fobia escolar. De acordo com Marcelli e Braconnier (2007), a recusa ansiosa escolar consiste numa expressão sintomática aguda do jovem relacionada à escola, acompanhada de uma angústia crescente referente a tudo o que diga respeito à vivência escolar.
} 
que esse termo seja mais expressivo na problemática do adolescente do que o termo já cunhado fracasso escolar, além de alinhar-se mais facilmente às patologias do agir. ${ }^{94}$

Vale assinalar que a recusa tem um caráter de negatividade, da recusa ao intercâmbio, no entanto ela corresponde a uma atuação, mas não a uma atuação-limite, ${ }^{95}$ como a passagem ao ato, que coloca em risco a vida do jovem. A atuação é diferente da passagem ao ato. Na primeira, há uma “dramatização em ato de uma cena psíquica”, como diz Birman (2006, p. 217), ou seja, a encenação está relacionada a uma representação inconsciente, ao passo que, na segunda, ocorre uma irrupção, uma pura descarga pulsional sem simbolização.

Jeammet (2000) salienta que a recusa trata de uma negatividade que vai além de uma oposição aos pais, uma vez que o maior prejudicado é o próprio jovem. Quando o sujeito se nega a ao intercâmbio, fica privado das coisas que o mundo adulto - o mundo da cultura oferece.

A recusa escolar, como outros tipos de recusa, parece apontar para uma deficiência advinda do aparelho psíquico, que se faz notar a partir da puberdade, quando o sujeito se vê despreparado para realizar as tarefas desenvolvimentistas ${ }^{96}$, segundo Jeammet e Corcos e percebe que ainda depende excessivamente de suportes externos, principalmente dos pais ou de certos adultos privilegiados. Isso porque, ao longo do desenvolvimento, o sujeito não desenvolveu suficientemente os suportes psíquicos internos ${ }^{97}$, que têm como função regular as tensões, desejos e conflitos, além de propiciar imagens de si.

Dessa forma, a dependência parece dizer respeito ao aspecto econômico da metapsicologia psicanalítica ${ }^{98}$, uma vez que se trata da dificuldade do aparelho psíquico de regular as tensões e necessitar de um suporte externo para alcançar um equilíbrio.

Se a dependência pode passar de forma relativamente neutra para o sujeito durante a infância, diante das mudanças operadas pela puberdade, em virtude da sexualização da

\footnotetext{
${ }^{94}$ Podemos entender as patologias de agir com o termo recusa como "operador" - anorexia: recusa a se alimentar; suicídio: recusa a viver, etc.

${ }^{95}$ Remetemos o leitor à apresentação de Mônica do Amaral (2006), no VI Colóquio do Lepsi: Culturas juvenis X cultura escolar: repensando as noções de (in)disciplina e autoridade no âmbito da educação.

${ }^{96}$ Mais especificamente, trata-se da integração do corpo sexual púbere com o acabamento das identificações sexuais, autonomização e separação dos objetos parentais.

${ }^{97}$ Os suportes psíquicos internos dizem respeito à diferenciação do aparelho psíquico.

${ }^{98} \mathrm{O}$ ponto de vista econômico da metapsicologia, de acordo com Laplanche e Pontalis (1985), diz respeito ao aparelho psíquico e a circulação e repartição da energia pulsional, isto é, as excitações internas e externas, que exercem uma pressão constante, dando origem aos investimentos, desinvestimentos, contra-investimentos e superinvestimentos, etc., no sentido de manter um equilíbrio, um nível baixo de energia no interior do aparelho psíquico.
} 
relação com os pais e da necessidade de se autonomizar, ela se torna problemática. Na presença dos pais, o jovem pode funcionar de forma organizada, no entanto, sem o suporte dos mesmos, regride a formas arcaicas de funcionamento e corre o risco de se desorganizar psiquicamente.

De forma geral, o adolescente que é muito tributário de suportes externos para manter o equilíbrio interno, por ter constituído de forma insuficiente as identificações, é voltado para a imagem que os outros fazem dele, e, por isso está sempre às voltas com a necessidade de auto-afirmação e de assegurar o afeto e apoio dos pais. A fragilidade e a falta de recursos internos se evidenciam diante de certas situações de frustração, levando o jovem a se fechar nessas condutas de recusa, que podem chegar a níveis drásticos.

Jeammet (2002, p. 6) demonstra que quanto maior é a dependência em relação aos apoios externos, mais o conflito com as figuras de apoio pode comprometer o equilíbrio do sujeito, pois a adolescência faz emergir não só a sexualidade do adolescente, como também sua agressividade. E o alvo das pulsões serão, inevitavelmente, as figuras de apoio externo, os pais. Os objetos mais investidos e em relação aos quais o jovem é mais dependente tornam-se antagônicos para ele. O adolescente contra-investe os elementos da realidade externa, principalmente os pais, para equilibrar uma via pulsional que permanece clivada, portanto separada do restante do eu e de suas possibilidades de elaboração.

Em outras palavras, o sujeito desinveste os objetos de amor e geralmente os substitui por outro elemento. ${ }^{99}$ Assim, aqueles indivíduos e objetos que o jovem aparenta rejeitar, como os pais, são aqueles que representam uma fonte de prazer tão intensa, que o sujeito teme ser invadido por tal sentimento e, por isso, como defesa, rejeita. Por outro lado, por meio da clivagem, ${ }^{100}$ o produto do desejo continua subsistindo e sendo investido.

A situação de dependência que se torna problemática na adolescência remonta à infância, segundo o autor, mais especificamente, ao desenvolvimento primitivo do indivíduo. Trata-se do processo de adaptação recíproca da criança e do ambiente, no qual a primeira constitui suas bases narcísicas. Quando ocorre uma falha do ambiente, geralmente representado pela figura da mãe ou de um adulto primordial, isso provoca uma ruptura do sentimento de continuidade do ser, tal como enuncia Winnicott (1990).

\footnotetext{
${ }^{99}$ Um dos substitutos freqüentes na adolescência é a droga.

${ }^{100}$ A clivagem do ego corresponde a um mecanismo proposto por Freud (1938a), no qual o ego, diante de um conflito com a realidade externa, divide-se, respondendo ao mesmo por meio de duas atitudes contrárias: de um lado, recusa a realidade, e de outro, reconhece a mesma. Mais à frente iremos nos deter sobre esse conceito.
} 
Como vimos no capítulo anterior, a qualidade das trocas da criança com o ambiente, a forma como ela vai sendo exposta às ausências e às falhas dos adultos privilegiados, sobretudo a mãe, representam uma possibilidade de a criança funcionar, ter prazer, desenvolver os próprios recursos psíquicos, interiorizar os vínculos, desde que essa experiência seja marcada pela estabilidade, possibilitando a vivência da continuidade do ser. Em um contexto assim, a criança pode constituir suas bases narcísicas sem perceber a importância do ambiente nesse processo, mesmo porque é provável que ela já disponha de certos recursos internos para lidar com determinados conflitos. No que diz respeito à aprendizagem, a criança sente um conforto interior e tem disponibilidade e liberdade para fazer trocas e ampliar seu repertório. Uma vez que já apresenta certos recursos psíquicos, sente-se segura para lidar com o mundo exterior.

No caso da criança que experimenta uma ruptura na continuidade do vínculo com a mãe ou com um dos adultos privilegiados, ela se sente impotente e percebe a dependência que estabelece com o ambiente. A adequação entre suas necessidades e o mundo exterior fica prejudicada. Nessas circunstâncias, a criança não constrói as bases de uma segurança interna e tem de recorrer ao super-investimento defensivo na realidade perceptivo-motora; como não interiorizou uma relação de segurança com a mãe, necessita da sua presença concreta. Em suma, em vez de desenvolver recursos psíquicos para lidar com os conflitos, é tributária dos objetos externos. Em relação à aprendizagem, a criança que vive em tal estado de insegurança volta-se para si mesma e não se abre para o mundo externo, pois este lhe parece ameaçador.

A criança dependente evita enfrentar os conflitos, lida com a angústia por meio de contra-investimentos em relação à realidade externa e acaba por não realizar o trabalho intrapsíquico devido, no sentido de desenvolver recursos próprios para lidar com os desafios. Dessa forma, estabelece uma relação mais anaclítica, isto é, de apoio com os objetos externos. Vale lembrar que, pelo fato de não ter investido nas fontes de gratificação próprias, ela não consegue se auto-satisfazer e o prazer advém somente do fato de adequar-se aos pais. ${ }^{101}$

Como afirmamos anteriormente, a dependência na infância pode transcorrer sem grandes problemas, apenas demandando dos pais uma presença constante, uma vez que a criança sofre um tipo de agarramento perceptual em relação a essas figuras, em virtude das poucas interiorizações que constituiu. No entanto, quando o sujeito dependente chega à puberdade, esse tipo de vínculo mostra-se conflitante, pois a autonomização pressupõe que o jovem disponha de fontes internas de gratificação e de valorização.

\footnotetext{
${ }^{101}$ A este tipo de constituição subjetiva Winnicott denomina falso self.
} 
Depreendemos da leitura de Jeammet (2002) que a puberdade, esse momento inicial de saída para o mundo mais amplo, confronta o jovem dependente com a insuficiência de seus recursos internos para lidar com as necessidades narcísicas, bem como com os conflitos pulsionais objetais. Cria-se, então, o antagonismo entre as bases narcísicas e as relações objetais.

O risco que se coloca, desta forma, é de o jovem perceber o quanto é tributário desses apoios externos. Qualquer desejo ligado aos pais, ou qualquer necessidade afetiva pode remeter o jovem a uma situação de impotência, de sentimento de ameaça à sua integridade, aos seus limites. Daí o recurso ao contra-investimento, ou, melhor, ao desinvestimento nas figuras parentais, à auto-sabotagem das próprias potencialidades e a recusa ao intercâmbio.

Nem toda criança dependente vai necessariamente tornar-se um adolescente que apresenta tais condutas. Vale lembrar o manejo do ambiente em face de tais problemas e, do lado do jovem, a maneira singular como o sujeito enfrenta o trabalho de integração psíquica do corpo sexual púbere e a gradativa autonomização em relação aos pais.

Diante da impossibilidade de alcançar um equilíbrio narcísisco, alguns adolescentes atuam e apresentam condutas próprias das patologias do agir. Outros, como Fábio e Otto, acabam por encontrar um conforto na situação de recusa escolar. A recusa acaba constituindo a única forma que o jovem encontra de expressar um desejo autônomo, de marcar a própria identidade e de estabelecer os limites entre o eu e o mundo externo. Mesmo que seja pela via da negatividade.

A recusa escolar representa uma forma de o jovem inverter a situação de dependência e de sentimento de impotência - é como se ele passasse a comandar a situação. Como afirma Jeammet (2007, p. 33), por meio da recusa, o adolescente acredita que pode controlar os seus desejos, assim como os objetos externos, principalmente os pais. Dessa forma, tem a ilusão de que não depende deles.

A questão da auto-afirmação é urgente para o adolescente, assim como a certeza do afeto dos pais. Ao abdicar das próprias potencialidades, o sujeito se antecipa ao fracasso para não decepcionar as figuras parentais, que constituem um espelho para ele. Vale marcar que o que ele ataca em si mesmo geralmente consiste em um objeto de investimento de um dos pais, como a facilidade para o cálculo matemático, a inclinação musical, etc. A expectativa, então, se transforma em recusa. Nas palavras de Jeammet (2007, p. 33): “Em vez de decepcionar-se, parece-lhes preferível não ter mais interesse”. 
Por meio da recusa, o jovem procura escapar ao controle dos pais, não correspondendo às suas expectativas e opondo-se aos supostos desejos deles. Dessa forma, ele se distancia dos pais, usa o fracasso para substituir uma eventual decepção e faz com que se submetam a ele, uma vez que ficam preocupados e atentos ao filho. Com isso, o jovem assegura para si o controle da situação.

Ao colocar-se na posição de recusa, o jovem vive uma trégua no conflito entre o mundo interno e o mundo externo pois, de um lado, fica aliviado da culpa do desejo incestuoso em relação a um dos pais e, de outro lado, não fica sozinho, já que é convertido em objeto de cuidado e de inquietação dos adultos, em virtude do seu comportamento. Paradoxalmente, a situação de proximidade, que fora evitada no início, por causa do prazer, em virtude do comportamento de recusa, acaba por prevalecer.

\subsection{A recusa da realidade}

A problemática da recusa escolar nos parece interessante para destacar certos elementos já abordados na discussão dos estudos de casos, que tratam justamente do enfraquecimento das barreiras geracionais, mais especificamente, a maneira pela qual certas interdições são transmitidas pelos pais aos filhos e como estes se posicionam subjetivamente em relação às mesmas. A herança que parece pesar sobre alguns jovens parece ser a ambivalência em relação às interdições e a manutenção da dependência em relação aos pais, que abriga, na verdade, uma situação de dependência mútua no grupo familiar.

O conceito de realidade, proposto por Freud, pode nos fornecer algumas pistas sobre a questão da complementaridade dos pais na conduta de recusa escolar do filho. De acordo com Penot (1992a), o termo "recusa” (verleugnung) ${ }^{102}$ foi utilizado inicialmente por Freud, em 1924, no texto “A perda da realidade na neurose e na psicose”, embora algumas obras anteriores já introduzissem essa idéia. No entanto, foi a partir de O fetichismo (1927) que esse conceito ganhou maior relevo em sua obra. Nesse estudo, Freud investiga a origem e o significado do fetiche e remonta à descoberta da diferença anatômica entre os sexos na infância, mais precisamente, à descoberta da ausência do pênis na mulher. A visão da mãe

${ }^{102}$ Esse termo é assim traduzido por Laplanche e Pontalis; já para a psicanálise lacaniana, é traduzido como "renegação". Segundo o Dicionário de Psicanálise, de Roudinesco, em 1967 o psicanalista Guy Rosolato propôs para esse termo uma nova denominação - "desmentido". 
castrada (ou da visão de meninas sem pênis, que levam a essa premissa) é uma realidade que o menino se recusa a aceitar, pois, se admitir esse fato, ele sofre o mesmo risco - ser castrado pelo pai. Vale marcar que, nesse período, o pênis é valorizado narcisicamente por ambos os sexos, e é muito difícil para as crianças admitir a ausência deste, daí a denominação fase fálico-narcísica, de acordo com Penot (1992a).

Para Freud, nos casos mais benignos, a ameaça de castração leva o menino a abandonar a masturbação e a reprimir o desejo incestuoso, o que deriva na resolução edipiana. Já nas meninas, a privação do falo gera a inveja do pênis e à recriminação da mãe, responsável por tal falha. Esse fato acarreta a entrada da menina no Complexo de Édipo, que vai implicar o afastamento da menina da mãe e a aproximação em relação ao pai, na esperança de ter o pênis dele para si, e culmina com o desejo de ter um filho com ele, de acordo com Freud (1938a). No fim do processo, com a resolução edipiana, dá-se a organização do superego e das identificações sexuais.

No caso do fetichismo, diante da percepção da mãe castrada, cria-se um conflito entre a realidade - a realidade da castração da mulher - e a força do desejo do menino, de continuar se masturbando sem correr o risco de perder seu pênis. A criança chega, então, a uma solução que contempla as duas partes: a proibição da realidade e a exigência pulsional. De um lado, o sujeito mantém a crença de que a mãe teve o falo, e, de outro, abandona tal idéia. Convivem, assim, duas realidades contraditórias. Essa solução se dá por meio da criação do fetiche, que é um objeto substituto do falo ausente. Assim, para o menino, a mãe teve um pênis, mas este mudou, configurando-se em um outro objeto (substituto simbólico do pênis).

A convivência de duas atitudes psíquicas contrárias no sujeito é possível graças ao mecanismo da clivagem do ego. Por meio desta, o sujeito apresenta duas disposições mentais diferentes: a recusa da realidade e a aceitação da mesma. As duas atitudes coexistem sem se influenciarem reciprocamente.

No Esboço da Psicanálise, Freud (1938a) discute o mecanismo da recusa e suas implicações no aparelho psíquico. Detendo-se nas relações do ego com o id e do primeiro com a realidade, aponta que a recusa não é rara no contexto infantil. Assim como o ego da criança recorre à repressão, livrando-se dos impulsos instintivos para responder às demandas da realidade, pode ocorrer o contrário: o ego, diante de uma exigência da realidade que o desagrada, por meio da recusa, se nega a reconhecer tal exigência, atendendo aos fins pulsionais. Nos adultos, segundo Freud (1938a, p. 233), esse mecanismo é mais freqüente nas 
perversões (como no fetichismo) e nas psicoses, mas também pode se manifestar em qualquer indivíduo. O próprio Freud reconhece esse mecanismo em si mesmo e o descreve, em 1936, na carta a Romain Rolland, mais especificamente, no relato sobre sua viagem a Atenas ${ }^{103}$. Entretanto, Freud alerta que a recusa consta de uma "meia-medida”, uma tentativa incompleta de se desligar da realidade.

Freud (1938b) esclarece que a recusa da realidade é possível graças à clivagem do ego, que consiste em uma divisão. A divisão do ego é uma condição universal das neuroses, e esta se dá entre duas instâncias, o ego e o id, por meio do recalque. Já no caso da clivagem do ego, trata-se de algo diferente, pois ocorre uma divisão intra-sistêmica, ou seja, duas atitudes psíquicas diferentes no interior do próprio ego. De acordo com Penot (1992b), essa divisão coloca dois setores do ego numa relação ao mesmo tempo de rejeição e de exterioridade um com respeito ao outro - um aceita a castração simbólica e o outro fica à mercê do conflito fálico-narcísico.

Para Bernard Penot (1992b), a manifestação de uma recusa persistente, isto é, para além do período fálico-narcísico, pode manifestar-se diante de determinadas circunstâncias, mais especificamente, numa situação de provação narcísica em que o sujeito se vê desprovido de recursos para lidar com um determinado conflito.

Bernard Penot, psiquiatra e psicanalista, que tem experiência na área da saúde mental com adolescentes, com o que se costuma denominar de casos-limites ${ }^{104}$, desenvolve um trabalho junto aos familiares que nos parece muito interessante para refletir sobre a articulação entre a problemática da recusa entre os jovens e o que ele chama de determinações familiares. De orientação lacaniana, Penot se debruça sobre a obra freudiana em Figuras da Recusa - aquém do negativo (PENOT, 1992a), a fim de aprofundar-se sobre tal conceito, com o objetivo de demonstrar que a problemática da recusa tem raízes na herança familiar, mais especificamente, nas mensagens parentais, o que parece ser bem enriquecedor para a nossa pesquisa.

Analisando a obra O Fetichismo, Penot (1992a, p. 55) afirma que a recusa se refere sempre à noção de recusa da ausência, como a ausência do pênis da mulher, ou da ausência (morte) do pai. Trata-se de não admitir um dado da realidade e o significado que isso pode acarretar, pois tal significação teria repercussões no sistema de referências que estrutura o

\footnotetext{
${ }^{103}$ Remetemos o leitor à leitura de "Um distúrbio de memória na Acrópole” (1936). Edição Standard Brasileira das Obras Completas de Sigmund Freud, Vol. XXII. Rio de Janeiro: Imago, 1974.

${ }^{104}$ Como já foi afirmado no capítulo anterior, trata-se de casos limítrofes, que não são nem neuróticos e nem psicóticos.
} 
psiquismo infantil - as teorias sexuais infantis. Lembrando que a simbolização se dá a partir da ausência de um objeto, o autor levanta a possibilidade de a própria função simbólica ficar comprometida. Nesse sentido, de acordo com Penot, a recusa da realidade representa um entrave ao trabalho do próprio pensamento.

Dessa forma, a recusa implica o que o Penot (1992a, p. 22) denomina abolição do sentido, ela consiste em uma operação psíquica de supressão da possível significação de certas representações do mundo externo. Trata-se de algo diferente do recalque, já que o retorno do recalcado representa justamente a emergência do significado, por meio das formações do inconsciente, como os sonhos, ato falhos, etc. No Fetichismo, Freud ajuda a diferenciar esses dois mecanismos: para ele, o recalcamento age sobre os afetos e a recusa, sobre as representações.

\subsection{A questão da econômica psíquica na recusa}

Penot (1992a, p. 29), seguindo as pistas deixadas por Freud, alerta para o problema econômico da recusa, que se viabiliza mediante a clivagem do ego. Esta, por sua vez, implica uma heterogeneidade fundamental - uma parte do ego funciona sobre o princípio do que ele denomina o jogo simbólico, estruturado pela dialética da presença e da ausência e pela diferença dos sexos, e a outra parte do ego, de característica narcísica, funciona com base na lógica unitária - ou seja, uma lógica em que se admite apenas um elemento. De acordo com essa lógica, o sujeito é considerado completo e não há espaço para a diferença. Tal heterogeneidade é radicalmente contrária à função primordial do ego, de garantir uma imagem de si unitária e constante.

A recusa na criança parece propiciar um benefício imaginário, visto que ela atribui certa integridade narcísica, no sentido de preservar a crença de um universo fálico de tipo unitário, como vemos com o pequeno Hans. ${ }^{105}$ No entanto, o fato de evitar o desprazer da descoberta da diferença representa, do ponto de vista econômico, um obstáculo à evolução psíquica da criança, pois, nessas condições, ela não se insere no princípio do prazer-realidade.

Para Freud (1915), o princípio do prazer está em continuidade com o princípio da realidade; este modifica o primeiro, fazendo com que a satisfação não se realize pelos

\footnotetext{
105 Trata-se da obra freudiana "Análise de um caso de fobia em um menino de cinco anos." (1909), Edição Standard Brasileira das Obras Completas de Sigmund Freud, Vol. X. Rio de Janeiro: Imago, 1974.
} 
caminhos mais curtos, mas tome caminhos mais longos e valorizados socialmente. $\mathrm{O}$ princípio da realidade representa a forma mais complexa de manter e regular o funcionamento do aparelho psíquico ${ }^{106}$. Ainda do ponto de vista econômico, o princípio da realidade consiste na transformação de energia livre em energia ligada. A ligação procura limitar o livre escoamento das excitações e a estabelecer laços entre as representações.

No caso da recusa persistente, a que se dá nos jovens e adultos, ela implica um entrave na economia psíquica, pois, de acordo com Penot (1992a, p. 32), certas zonas do psiquismo ficam submetidas aos imperativos de certa integridade imaginária, sob o modo narcísico-fálico, sendo então regidas pelo princípio do prazer. Em outras palavras, em certas zonas do psiquismo não há espaço para a instauração do princípio da realidade. Nesse sentido, é inviabilizada a possibilidade de simbolização, uma vez que as representações são marcadas pela abolição simbólica.

Para Penot (1992a), a problemática da recusa consiste justamente no funcionamento imaginário, ${ }^{107}$ que resiste ao estabelecimento da função simbólica, devido ao desprazer que a admissão da castração acarretaria. Entretanto, a aceitação da castração representa a única forma de garantia de regulação narcísica, pois ela possibilita a instauração do fundamento no princípio de prazer - realidade na economia psíquica do sujeito. Quando este é instaurado, viabiliza-se a ligação psíquica, isto é, a possibilidade de ligar representações entre si, de investir as representações de forma mais estável. Dessa forma, a satisfação instintiva é adiada, possibilitando experiências mentais que viabilizam formas mais elaboradas de gratificação.

A manutenção de uma parte do psiquismo regida pelo princípio do prazer pressupõe uma economia pulsional em que predominam as pulsões de morte. Segundo Freud (1938b, p. 173), elas têm o objetivo de desfazer as conexões, de deixar as representações em um estado de não ligação psíquica. Isso implica a abolição simbólica e o prejuízo da própria atividade do pensamento, pois não é possível simbolizar e nem elaborar os conflitos, restando ao sujeito a compulsão à repetição.

\footnotetext{
${ }^{106}$ Isso não quer dizer que o princípio da realidade suprima o princípio do prazer - este continua a predominar no domínio do inconsciente.

${ }^{107}$ Lacan postula que a criança constitui sua subjetividade a partir da imagem do seu semelhante. Esse conceito é formulado no "Édipo estrutural". Fazendo uma referência ao "estádio do espelho", afirma que há, inicialmente, uma relação de alienação entre a criança e seu semelhante, primordialmente a mãe. Trata-se da relação imaginária, dual, eminentemente narcísica. Na perspectiva da significação, o funcionamento imaginário implica uma forma de apreensão em que a semelhança desempenha um papel fundamental, determinando um tipo de relação significante - significado marcado por certa aderência do primeiro ao segundo.
} 
O caso de jovens que apresentam a recusa persistente, como descreve Penot (1992a), remete aos casos examinados por Jeammet e Corcos (2005), dos adolescentes que são dependentes das figuras parentais, pois não desenvolveram recursos internos para lidar com os conflitos entre o mundo interno e o mundo externo. Segundo os autores, isso resulta de uma diferenciação do aparelho psíquico incompleta, pois o sujeito não conseguiu constituir elementos suficientes de maneira a poder estabelecer um jogo entre as instâncias psíquicas a fim de lidar com os afetos e representações, no sentido de minorar a força dos estímulos externos que ameaçam o mundo interno.

Para Penot (1992a, p. 33), a problemática da recusa e a conseqüente abolição simbólica que prevalece em certas zonas do psiquismo do sujeito estaria relacionada com a instância superegóica, como se houvesse uma falta de simbolização nas próprias mensagens parentais. Como sabemos, o superego é conhecido como o herdeiro do complexo de Édipo e é constituído pela interiorização das exigências e interdições parentais. O autor lembra que as instâncias parentais são introjetadas com suas qualidades e características próprias, e ele acrescenta: simultaneamente, o sujeito também introjeta uma forma de pensar.

Pois bem, no caso da recusa, o sujeito se identifica com figuras parentais que o autor denomina "mal psiquizadas" (PENOT, 1992a, p. 34); os pais teriam, em sua história, representações que foram marcadas pela operação psíquica da recusa, permaneceram no estado de não-ligação e, por isso, não passaram pelo processo de simbolização. Dessa forma, as mensagens parentais estariam marcadas por uma lacuna de simbolização, sobretudo nos dados relativos à própria criança, impedindo o sujeito de lidar de outra forma com esse referencial, a não ser por meio da recusa. É como se houvesse um sistema de pensamento que seria transmitido de pai para filho.

Nas Novas Conferências Introdutórias de Psicanálise (1932), Freud relembra que a base da formação do superego se dá por meio da identificação - a criança se identifica com as figuras parentais, imita-as, e, de certa forma, assimila-as dentro de si. Na época da constituição do superego, o vínculo com os pais é tão forte que, para a criança, eles condensam todas as qualidades humanas - beiram à perfeição. ${ }^{108}$ Só mais tarde a criança consegue tomar distanciamento, podendo estabelecer um juízo mais crítico em relação às figuras parentais. Para todos os efeitos, são esses pais supervalorizados da primeira infância

\footnotetext{
${ }^{108}$ O modelo da perfeição é instituído pelo ideal de ego e este advém do próprio superego. O ideal do ego é constituído a partir da imagem dos objetos amados.
} 
que vão constituir as imagos que estruturam o superego. Posteriormente, outras figuras, como educadores e adultos significativos, também vão compor essa instância psíquica.

O superego parece encarnar todas as virtudes, o que há de mais nobre no ser humano. Assim, quando um pai ou professor educa uma criança, ele se orienta por seu próprio superego, sendo exigente e severo em relação ao pequeno. Daí o paradoxo: embora o adulto tenha críticas no presente em relação às figuras parentais, inspira-se justamente nessas imagos primitivas para educar as gerações seguintes ${ }^{109}$. Nesse sentido, Freud (1932, p. 87) afirma que o superego de uma criança é constituído não tanto segundo a imagem dos pais, mas do superego dos seus pais; a criança herda elementos advindos da história psíquica dos pais e de seus antepassados. Dessa forma, podemos constatar que o conjunto de identificações que conforma o superego não constitui um sistema coerente: no seio dessa instância encontram-se exigências diversas e conflitantes.

A noção de energia psíquica ligada, que pode ser utilizada para a atividade do pensamento, está diretamente relacionada à questão da simbolização - é ao admitir a realidade da castração e ao realizar o luto edipiano que o sujeito atinge uma estrutura de pensamento que permite lidar simultaneamente com a realidade interna e externa.

No caso da recusa, o sujeito, ao introjetar representações advindas dos próprios pais, herdaria, dentre os legados, os restos de um trabalho psíquico incompleto, como a não admissão da castração, o que implica um funcionamento sob o primado do princípio do prazer em certos domínios. Disso resulta uma incapacidade de pensar sobre determinadas questões, correlata às falhas no pensamento das figuras parentais. Em outras palavras - aquilo que o sujeito atua por meio da recusa, na verdade, diz respeito a questões que os próprios pais se recusaram a admitir e a pensar. Nesse sentido, podemos afirmar que haveria um determinismo transgeracional.

Utilizando o referencial lacaniano, Penot fala do discurso parental que envolve a chegada de um filho, o qual é constituído de significantes relativos aos desejos dos pais e teria a força de um oráculo, estabelecendo o próprio destino do sujeito. O autor denomina, ao núcleo de significantes que aninha a criança, matriz narcísica, que é determinante para a relação da criança com a realidade interna e externa.

\footnotetext{
${ }^{109}$ Isso diz respeito mais à forma que os adultos se posicionam do que em relação ao conteúdo das normas que vão transmitir às crianças.
} 
Para Maud Mannoni (1971), a criança é marcada, não somente pela maneira como é aguardada antes de nascer, mas também pelo que ela, depois de nascer, representa para os pais, em relação à história de cada um; muitas vezes, a criança pode ficar alienada em relação ao desejo deles, presa a uma relação dual.

Como já foi dito anteriormente, a manifestação de recusa nos adolescentes geralmente se dá numa situação que se configura como uma provação narcísica que ultrapassa os recursos internos do sujeito. Trata-se de jovens que apresentam uma dificuldade narcísica particular e por isso dependem dos pais como suporte externo diante de certos contextos. A partir de sua experiência clínica, Penot aponta que, na verdade, há no grupo familiar uma dependência mútua.

... se estes adolescentes continuarem a depender vitalmente de suas instâncias (parentais) reais e atuais, em uma "tópica" especular pouco mediatizada, a contrapartida disso é, geralmente, que este mesmo núcleo familiar (o casal parental, os irmãos e irmãs...) também utilize o adolescente como uma peça essencial a seu próprio equilíbrio e a sua sobrevivência. (PENOT, 1992a, p. 122)

Há uma complementaridade nessa dependência - o equilíbrio familiar está ancorado na manutenção do sintoma do jovem, o que nos parece ser a maior contribuição do autor para a nossa pesquisa.

Acreditamos que já dispomos de elementos suficientes para estabelecer uma interlocução entre os referenciais teóricos de Jeammet (2000) e Penot (1992a). Nossa intenção não é reduzir a idéia de recusa escolar do primeiro ao conceito de recusa da realidade do segundo, pois ambos guardam especificidades e tratam de questões que ora se tangenciam, ora se distanciam. Interessa-nos os pontos convergentes entre esses autores. Vamos citar aqueles que mais nos chamam a atenção: ambos tratam de um sintoma que se manifesta diante de um confronto narcísico ${ }^{110}$. Outro ponto é que ambos postulam que a problemática da recusa remonta ao desenvolvimento primitivo da criança. Ainda em relação à evolução psíquica do sujeito, os dois afirmam que há uma grande influência do modo como o ambiente (os pais) respondem às demandas do adolescente. A qualidade das respostas advindas do ambiente é fundamental para a superação ou manutenção da dependência do jovem. Por fim, ambos dão relevo à perda da capacidade de simbolização nos jovens, à reduzida possibilidade de representação e de expressão mental em face de um conflito intrapsíquico.

\footnotetext{
${ }^{110}$ As transformações da puberdade representam uma situação dessa natureza.
} 
Buscando agora articular esses referenciais aos casos de Fábio e Otto, acreditamos que esses jovens apresentavam o sintoma de recusa escolar, tal como depreendemos da leitura de Jeammet (2000), no entanto essa manifestação também parecia articular-se à recusa da realidade advinda dos próprios pais, mais especificamente, recusa a aceitar a diferença geracional e a exercer o papel de adulto na educação dos filhos. No momento em que era exigida uma maior autonomização em relação aos adolescentes, eles apresentavam um sintoma na aprendizagem, sintoma este relacionado tanto à problemática da adolescência, como à impossibilidade dos próprios pais expressarem e elaborarem um conflito que lhes dizia respeito. Nesse sentido, acreditamos que havia, de fato, nos grupos familiares em questão, o que Penot (1992a) denomina uma dependência narcísica mútua.

Jeammet (2000) lança novas luzes para a compreensão de certos problemas de aprendizagem que se manifestam por ocasião das transformações da puberdade, dando enfoque à ressonância entre a necessidade de autonomia que certas transições na escolaridade representam, com a passagem da adolescência, sendo esta entendida pela demanda do sujeito por um novo equilíbrio entre o mundo interno e o mundo externo. Penot (1992a), por seu lado, aponta como os pais são partícipes desse problema e como as mensagens (conscientes e inconscientes) que são transmitidas aos filhos são determinantes para o destino desses jovens.

Partindo da premissa de que a recusa escolar pode ser compreendida como um sintoma na aprendizagem, acreditamos que este não parece derivar somente de conflitos dinâmicos intrínsecos aos adolescentes. Ao contrário, concordamos com Maud Manonni (1985), quando afirma que, por trás de um sintoma de uma criança ou adolescente, constata-se uma desordem familiar. A nosso ver, esse sintoma está diretamente relacionado a uma problemática dos próprios pais.

Para Françoise Dolto (1985), psicanalista lacaniana, a matriz narcísica na qual um filho é gerado pode ser contaminada pela transferência de vivências arcaicas dos pais. É todo um passado anterior que se projeta sobre o filho. Tal projeção acaba por aprisionar a criança no desejo dos pais.

De acordo com Mannoni (1971, p. 48), há uma comunicação inconsciente entre mãe e filho e muitas vezes a criança é informada, de certa maneira, do que a mãe (e eu acrescento: e o pai) deseja ou recusa. Fazendo uma leitura da obra freudiana do Pequeno Hans, a autora observa que a criança é muito sensível ao discurso dos pais - tanto às palavras, como aos silêncios. Onde um adulto pode observar apenas o conteúdo manifesto, a criança, por não ter o funcionamento do recalque tão ativo, recebe uma mensagem rica de significados latentes. 
Nesse sentido, acreditamos que esses jovens são porta-vozes de seus pais. O sintoma de recusa escolar consiste, então, numa ressonância às angústias ou aos processos reativos à angústia de seus pais. Para Dolto,

A exacerbação ou a extinção dos desejos, ativos ou passivos, da libido ou da simbolização na criança ( $e$ no adolescente), das suas pulsões endógenas são a resposta complementar aos desejos reprimidos de pais insatisfeitos na sua vida social ou conjugal, e que esperam da sua progenitura a cura ou a compensação para o seu sentimento de fracasso". (1985, p. 13)

Haveria, assim, uma complementaridade entre o sintoma do filho e o desejo dos pais. É como se o filho pudesse, por meio da recusa, realizar os desejos reprimidos dos próprios pais.

A fim de elucidar como se articula o sintoma, do ponto de vista dinâmico, é necessário retomar a noção de conflito psíquico. Há, no aparelho psíquico, um verdadeiro jogo de forças entre a libido e as interdições; estas provêm primeiramente do mundo exterior, e posteriormente do superego, quando este já se constituiu. Para Freud (1923), a libido é como um manancial inesgotável - ele tem de fluir e jamais pode ser estancado. Partindo dessa idéia, Dolto (1984) esclarece que, quando o impulso libinal ligado a uma representação é reprimido, a carga afetiva jamais desaparece. Ela se mantém e se converte em angústia - o sofrimento resultante do conflito entre as pulsões e as interdições.

Quando a angústia encontra uma forma de ligar-se a uma outra representação, mais aceita pelo mundo externo, tem-se a formação de um sintoma, que consiste na utilização da pulsão reprimida de uma maneira "disfarçada"; a manifestação do sintoma possibilita ao sujeito libertar-se da angústia. Há, no entanto, uma forma alternativa de utilização da pulsão reprimida, e esta se dá por meio da sublimação, do direcionamento da libido para atividades culturais valorizadas pelo mundo externo e que são propiciadas pelo superego.

No caso em que as possibilidades de sublimação são insuficientes ou em que o id é muito violento, pode ocorrer a formação de sintomas, passagens ao ato, como as patologias do agir, entre outras manifestações. Uma possibilidade intermediária seria o recurso da elaboração psíquica, ou seja, a transformação da energia pulsional, estabelecendo ligação entre as representações a fim de permitir o processo representativo, a simbolização. Entretanto, como já foi afirmado anteriormente, é justamente a capacidade associativa a atividade de pensamento que falha no caso da recusa. Dessa forma, resta ao jovem somente a primeira possibilidade. 
Para Jeammet (2000), a recusa escolar estaria relacionada à situação de dependência, mais especificamente, à insuficiência de recursos internos pra lidar com as questões narcísicas e pulsionais colocadas pela adolescência. Apesar de apontar a relevância do ambiente nesta problemática, a ênfase parece recair no conflito dinâmico intrínsico do adolescente. A nosso ver, as contribuições dos psicanalistas lacanianos, como Penot, Dolto e Mannoni, consistem em dar um relevo ao lugar do ambiente nessa problemática, ao papel complementar dos pais nesse sintoma.

Como já afirmamos, não pretendemos justapor diferentes formulações teóricas, mas apontar, por via do diálogo entre os autores, a abrangência de fatores que intervêm na problemática da recusa escolar.

Como vimos com Jeammet (2000), a recusa escolar teria para o jovem a função de inverter a situação de dependência e de sentimento de impotência em relação aos pais; mediante a recusa escolar, ele teria a ilusão de que controla seus desejos. A nosso ver, no caso de Fábio e Otto, esse sintoma acaba por mostrar-se uma resposta complementar aos desejos reprimidos dos pais. O sujeito estaria, sim, por meio do sintoma, expressando como está aprisionado numa relação dual. Nesse sentido, não seria o jovem a controlar a situação familiar, mas justamente o contrário.

Vale marcar que toda a recusa, em última análise, trata da castração. Para Dolto (1984, p. 18), a castração significa a frustração das possibilidades de busca do prazer. É evidente que estes jovens, ao desqualificarem a escola e rejeitarem o ofício de aluno, se recusam a entrar na lógica do adiamento do prazer proposta pela escola. Poderíamos, então, levantar a hipótese de que, aos olhos dos próprios adolescentes, eles estariam marcando o seu desejo de autonomia, de oposição à regra social. No entanto, apesar do aparente descontentamento dos pais, estes acabam por legitimar essa recusa escolar. O pai de Fábio é o primeiro a querer tirá-lo da escola. Na verdade, os pais parecem realizar seus desejos por meio dos filhos. No entanto, o sintoma pode ser entendido como uma denúncia, como algo que merece uma escuta. Como pedido de ajuda, pode ser, então, considerado uma forma de expressão de um desejo autônomo.

Remetendo-nos agora aos casos em questão, em relação a Fábio, o primeiro ponto que podemos destacar é a matriz narcísica que o envolveu, as expectativas geradas em torno desse filho temporão, que simbolizava a juventude, a vitalidade do casal e a renovação de projetos de futuro, concretizados pelo nascimento do filho e pela mudança de cidade. Vale acrescentar que essa mãe estava em luto pela morte da própria mãe, e o apego com o bebê foi 
marcado por uma grande intensidade. Assim, tanto o nascimento como a educação de Fábio foram representadas por uma vontade de mudar e de tentar realizar alguns ideais acalentados pelos pais. No entanto, esses ideais foram sendo gradativamente confrontados com a realidade e se mostraram inadequados. Apesar de reconhecerem que criaram um "enfant sauvage”, os pais insistiam em manter uma atitude crítica em relação às normas e à institucionalização.

Nesse sentido, a recusa de Fábio a entrar no jogo escolar parecia advir, de uma parte, da problemática da autonomização da adolescência, e, de outra parte, tanto da falha na inscrição da interdição incestuosa da relação dual com a mãe, como também, de uma dificuldade dos pais de se submeterem às demandas da realidade, para eles representadas pela normalização, pelas regras e pela sistematização. Na visão desses pais, a entrada na instituição significava a perda da autenticidade e, mais do que isso, implicava o reconhecimento de que o filho havia crescido e que poderia sair do círculo familiar. Desconfiados do outro - a escola e os profissionais da área "psi”, acabavam por criar obstáculos para a inserção do filho em outros meios e outros vínculos. Insistiam em mantê-lo restrito ao mundo privado, pois desconfiavam do mundo público, como se este pudesse "corrompê-lo”. Desejavam manter a utopia de uma vida com valores autênticos, impermeáveis ao mundo capitalista, como se ainda fossem um jovem casal, que está experimentando formas alternativas de educar seu filho pequeno. Na realidade, ele já tinha catorze anos e os outros filhos eram quase adultos, sendo que um deles já havia saído de casa ${ }^{111}$ e o outro já trabalhava.

De certa forma, a dependência de Fábio em relação aos pais e toda a energia que dispensavam ao caçula propiciavam o equilíbrio familiar descrito por Penot (1992a), pois dessa maneira, deixavam os filhos maiores em paz, levando suas vidas sem a interferência parental. O benefício narcísico dos pais advinha do fato de que o sintoma de Fábio os tornava pais “jovens”, que devem cuidar sem descanso de seu bebê.

A recusa escolar de Fábio estava, então, articulada à recusa dos pais em aceitarem que haviam fracassado em sua aposta reformadora e de aceitarem que já não eram mais jovens, com todo o tempo pela frente para mudar o mundo. A recusa escolar advinha igualmente da falha do pai na interdição da relação dual com a mãe, que, por sua vez, insistia em manter um relacionamento ambivalente com o filho, procurando manter acesa a chama do desejo deste por ela. Lembrando o que afirmamos anteriormente sobre a dimensão pulsional, que se manifesta em todos os fenômenos e relações da vida do sujeito, se o prazer torna-se

\footnotetext{
${ }^{111}$ Segundo o médico da família, o filho mais velho havia escolhido estudar em outro estado, justamente para se distanciar do núcleo familiar.
} 
ameaçador para o sujeito, resta a manifestação da pulsão de morte, da agressividade. Daí o comportamento agressivo de Fábio em casa.

No que diz respeito a Otto, algo que nos parece chamar a atenção em seu funcionamento é como este é apanhado pela dimensão da separação na aprendizagem. Costumava criticar os professores, inclusive os desqualificava, para justificar seu desinteresse ou seu baixo desempenho. Fazia uso do deslocamento, desviando o foco da discussão para o outro, para não experimentar a angústia ao confrontar-se com a sua incompetência, sua falta. Enfim, de acordo com Vera Blondina Zimmermann (2001), o que ele estava de fato recusando era o não saber.

No caso de Otto, a recusa escolar articulava-se à problemática da adolescência, à situação de mudança de cidade e de referência familiar, que representa um conflito narcísico. No entanto também parecia advir da recusa do pai em aceitar a diferença geracional, pois isso implicava sair da posição de filho dos seus pais e entrar na vida adulta, assumindo, assim, a responsabilidade por seu próprio filho - por isso se colocava como irmão de Otto. Nesse caso, parecia haver um determinismo familiar, pois os avós nada fizeram para mudar seus laços com o filho e o neto, mantendo-os na posição de filhos que necessitam dos seus cuidados. Assim como Cronos, que come os próprios filhos para não ser suplantado por seus rebentos, os avós pareciam se recusar a sair da posição de provedores das gerações seguintes. A mensagem parental que transmitiam parecia ser: cresçam, mas não superem seus antecedentes - até academicamente - pois os avós alcançaram postos importantes na universidade ${ }^{112}$. Nesse sentido, as gerações seguintes aparentavam obedecer tal ordem, pois o filho, apesar de escolher a carreira acadêmica, não havia sido muito bem-sucedido em seu doutorado no exterior (tanto é que a bolsa não fora renovada), e o neto, por sua vez, apresentava fracasso escolar e corria o risco de ser reprovado pela segunda vez.

No caso da mãe de Otto, ela também se colocou como filha desde o início na família do marido, não parecendo mostrar oposição quanto a essa cultura familiar. A decisão de partir e deixar o filho sob a guarda dos sogros parece ser uma evidência de que os reconhecia como mais aptos para cuidar do filho do que ela própria e o ex-marido. Ela também parecia manifestar a recusa da realidade, ao não admitir perder as prerrogativas da juventude, abandonando o próprio filho em prol da sua liberdade. Em outras palavras, recusou o seu lugar de mãe.

\footnotetext{
${ }^{112} \mathrm{O}$ avô recebia, quando vivo, uma boa remuneração na universidade, referida pelo filho como "salário de marajá”, e a avó ocupava o cargo de diretora de uma faculdade desta universidade.
} 
Vale marcar que vigorava um certo psicologismo na família e a educação vigente tinha sido marcadamente liberal. Segundo o pai, sua família "não apostava no autoritarismo e nem na subordinação”, o que reforçava a posição de desafio em relação às ordens. Nesse sentido, o pai sempre fora muito ambivalente em relação às normas, haja vista sua omissão no caso do consumo de maconha do filho. Nesse caso, podemos afirmar que esse pai se recusava a se colocar como adulto, numa posição assimétrica em relação ao filho. Ao contrário, posicionou-se mais uma vez como um igual, como alguém que não consegue realizar uma interdição, mesmo sabendo do risco que o uso da maconha podia representar ao desempenho escolar do filho. A interdição veio da avó - e mais uma vez o pai de Otto se recusou a assumir o seu posto, delegando à sua mãe a guarda do filho. Voltou sem qualquer oposição à relação fraternal com Otto.

Como vimos, a recusa escolar trata de um sintoma na aprendizagem, que se manifesta frente à necessidade de autonomização do adolescente. Constatamos o papel fundamental do ambiente, no sentido de favorecer esse processo, ou, ao contrário, de impedilo e manter o jovem preso ao vínculo de dependência.

Para Jeammet (2000), a intervenção terapêutica necessária para ajudar o adolescente a se desenredar da relação de dependência seria o ambiente apresentar um adulto, assim como na apresentação de objeto, de Winnicott (1990), que tenha uma empatia com o jovem e possa se adaptar às suas necessidades, a fim de recuperar o equilíbrio entre investimento de objeto e as bases narcísicas.

Nos casos de recusa escolar, acreditamos que a psicopedagogia se configura como uma das intervenções possíveis. Por meio desse atendimento, procura-se estabelecer uma relação com o adulto marcada pela assimetria, no sentido de que as diferenças geracionais estejam claramente afirmadas, e o objetivo é favorecer o investimento nas potencialidades que sofreram um boicote do próprio adolescente, por meio da realização de projetos que propiciem uma produção por meio da qual o jovem se reconheça. Busca-se, igualmente, favorecer a subjetivação do adolescente mediante a fruição cultural.

Observamos que o ambiente é fundamental nessa travessia que o jovem faz para realizar o trabalho psíquico de consolidação de suas bases narcísicas e investimento em novos objetos, no sentido de ampliar suas identificações. Como vimos, esse processo só se efetiva quando há, na família, modelos identificatórios que propiciam o estabelecimento das diferenças geracionais. É essa diferença que permite ao adulto marcar os limites, dar o suporte necessário e preparar o caminho que o jovem vai percorrer para constituir sua autonomia. No 
entanto, o que se observa, e os casos de Fábio e Otto ilustram, é que cada vez mais há "uma excessiva sobreposição dos laços geracionais”, segundo Jeammet e Corcos (2005, p. 65).

A riqueza do estudo desses autores, como nos aponta Mônica do Amaral (2005), advém do fato de eles defenderem que o ambiente deve ser um co-responsável pelo desenvolvimento do adolescente, uma vez que as instituições e o quadro social não propiciam mais as bases para a constituição da subjetividade do jovem.

Até aqui procuramos estudar a adolescência e a manifestação de novos sintomas, como as patologias de agir e o comportamento da recusa escolar na contemporaneidade. Essas manifestações parecem estar relacionadas a certos elementos que subjazem às tendências sociais, assim faz-se necessário um aprofundamento sobre a atual configuração social. Para isso, vamos recorrer a Gilles Lipovetsky (2006), pois ele estuda a mutação histórica e cultural que se deu na modernidade, dando lugar à nova ordem sociocultural. 


\section{Narcisismo ou a condição subjetiva na contemporaneidade}

Quando enfrentam o que seu passado não as preparou para enfrentar, as pessoas tateiam em busca de palavras para dar nome ao desconhecido, mesmo quando não podem defini-lo nem entendê-lo. Em determinado ponto do terceiro quartel do século, podemos ver esse processo em andamento entre os intelectuais do Ocidente. A palavra-chave era a pequena preposição “após”, geralmente usada na forma latinizada "pós” ou "post” como prefixo para qualquer dos inúmeros termos que durante algumas gerações foram usados para assinalar o território mental da vida no século XX. (Hobsbawn, 1995, p. 282)

Ainda vivemos em um mundo onde parece faltarem algumas chaves para compreendê-lo, bem como para nos posicionarmos perante os acontecimentos com os quais nos deparamos. Se havia um termo que possibilitava uma ancoragem ao sujeito, até algumas décadas atrás, esse termo era modernidade. Ele possibilitava a atribuição do sentido histórico, de pertencimento a uma cadeia de gerações advindas do passado, ainda que significasse uma ruptura com essas gerações; a idéia era que a história se encaminha para o futuro. Esse sentimento de pertença ao mundo vivido aparenta ter declinado. Para Juremir Machado da Silva (2006), a sociedade está liberta das ilusões do futuro e das coerções do passado. Essa dita liberdade deriva de uma mutação histórica, que implica uma ruptura com a ordem anterior e a mudança de posicionamento em relação aos fundamentos existentes.

Essa mutação, que é sentida no cotidiano, nas trocas sociais e nas relações intergeracionais, assinala o declínio do que Castoriadis (1992) chamou de "significação imaginária central” da modernidade, que consiste em um conjunto de organizações e significados, de ações e valores que foram construídos historicamente. Nas últimas décadas, um novo ideário passou a orientar as relações sociais. Para compreender tal transformação, faz-se necessária uma volta às origens, um olhar histórico para verificarmos as continuidades e as descontinuidades em relação à ordem anterior.

\subsection{O projeto moderno}

Fazendo uma breve retrospectiva, a modernidade emerge no século XVI, como a concretização do projeto iluminista e humanista de libertar o homem do dogma e de colocá-lo no centro do mundo, constituindo-o como a medida de todas as coisas. Mais especificamente, a modernidade referencia-se pela ideologia do indivíduo auto-suficiente, livre, autônomo e semelhante aos outros. Para Marshall Berman (2000), o mito de Fausto é exemplar no sentido 
de ilustrar tal projeto. Trata-se da alegoria do indivíduo moderno, que, por meio da razão e da ciência, desafia e desaloja o poder divino e estabelece o processo de racionalização do mundo.

No contexto posterior à Revolução Francesa, as sociedades modernas estabeleceram instituições sociais identificadas com os valores da liberdade e da igualdade ou como espaço que possibilitassem a afirmação das mesmas. Entretanto, a institucionalização se sustentava na coerção, no sentido de realizar o projeto de indivíduo homogêneo. Acreditava-se que os valores individualistas só poderiam se efetivar no contexto de uma ordem social normativa e padronizadora.

Sergio Paulo Rouanet (2000) demonstra que a modernidade orienta-se sobre dois vetores: um funcional, sistêmico, ligado à racionalidade instrumental, e outro, marcadamente humanista, associado à racionalidade emancipatória. No primeiro vetor, o ideal é eficiência, e no segundo, o ideal é autonomia. Desses vetores, derivam também as respectivas noções de indivíduo moderno. Para Dubet e Martucelli (1996), o individualismo baseado no vetor da racionalidade instrumental prega o culto da performance, da capacidade de domínio do meio, de uma mentalidade que articule os meios aos fins. $\mathrm{O}$ outro individualismo, baseado no humanismo, é fundado sobre a expressão, o desejo de alcançar e preservar a autenticidade.

Em outras palavras, o dispositivo fundamental da modernidade é a formação ilusória da soberania do indivíduo. De acordo com Joel Birman (2000, p. 189), a figuração da subjetividade é concebida, nesse contexto, pela proeminência atribuída ao Eu, que passa a ocupar a centralidade do sujeito, constituindo o seu fundamento.

A modernidade é identificada com o espírito empreendedor da burguesia e com a esperança depositada no futuro. Fazendo uso da razão e da ciência, o sujeito disciplinar e voluntário, segundo Gilles Lipovetsky (2006), empreende o processo de racionalização do mundo. ${ }^{113}$ A sociedade representa a forma da organização social moderna e o imaginário que a sustentou por quase dois séculos consiste na integração entre a economia, a organização social e a cultura.

Rouanet (2000) demonstra que a racionalização do mundo vivido proposta pela modernidade possibilitou a emancipação do indivíduo, no entanto também teve conseqüências adversas. A racionalização nas esferas do Estado e da economia se dissociou do mundo vivido

\footnotetext{
${ }^{113}$ De acordo com Rouanet (2000), citando Max Weber, esse processo se dá por duas vias: a modernidade social e a modernidade cultural. A modernidade social caracteriza-se por complexos institucionais autonomizados - 0 Estado e a economia - que escapam crescentemente ao controle dos indivíduos, mediante mecanismos cada vez mais automáticos; em termos práticos, é o processo de burocratização. Já a modernização cultural é o processo de racionalização das visões de mundo e sua substituição por esferas axiológicas: ciência, moralidade e arte.
} 
e se incorporou em uma esfera sistêmica, comandada pela razão instrumental. Em suma, a racionalização sistêmica se impôs sobre os indivíduos, resultando em uma perda de liberdade.

Depreendemos da leitura de Rouanet (2000) que o vetor instrumental parece ter se sobreposto ao vetor emancipatório. Ora, a díade harmoniosa entre razão e liberdade, como produto do progresso, constituiu um dos pilares do projeto da modernidade. Essa e outras tantas contradições levaram muitos pensadores a decretarem a falência da modernidade.

\subsection{A modernidade em crise}

O primeiro a fazer tal colocação foi François Lyotard (1998). No seu entender, a sacralização da razão empreendida pela modernidade deu origem ao cientificismo, positivismo e a algumas metanarrativas ou grandes narrativas de legitimação. Estas consistiam em discursos que atribuíam um sentido ao mundo e por isso os indivíduos se submetiam a elas. A ciência era legitimada por duas formas de grandes narrativas: a primeira, derivada da Revolução Francesa, que pregava a humanidade como agente da libertação por meio do conhecimento, e a segunda, que postulava o espírito como revelador da verdade.

Para Lyotard (1998), a tecno-ciência, tão valorizada desde a segunda metade do século XX, não parece estar mais a serviço da libertação do homem, mas sim do poder. A ciência passou então a ser legitimada pela eficiência. Nesse sentido, os dois mitos que justificaram a modernidade perderam sua legitimidade. Por isso o filósofo assinalou, nessa perda de legitimidade, o fim das grandes narrativas. Em outras palavras, o fim da modernidade.

Na verdade, a crença no fim da modernidade deriva de um processo mais amplo de transformações, a qual, segundo Stuart Hall (2005), se deu na modernidade tardia, ${ }^{114}$ por meio do deslocamento de estruturas e processos centrais das sociedades modernas e isso levou a uma desestabilização dos quadros de referências que possibilitavam aos sujeitos certa ancoragem no mundo social. Tal desestabilização leva alguns autores a intitularem o atual contexto sociocultural como pós-moderno, acreditando no esgotamento das estruturas propostas pela modernidade.

O fim da modernidade foi motivo de polêmica entre Lyotard e Jürgen Habermas. Em seu clássico escrito, A modernidade inacabada, Habermas (2002) defende o potencial da razão.

\footnotetext{
${ }^{114}$ Para Hall, a modernidade tardia se localiza na segunda metade do século XX.
} 
Acredita que mecanismos de poder próprios da modernidade social acabaram por interferir na estrutura comunicativa do mundo vivido. Ou seja, não houve propriamente uma ruptura com a modernidade, mas sim uma intensificação de alguns princípios da mesma. Para ele, seria necessário rearticular a razão e a emancipação por meio de uma ética discursiva, por ele denominada “razão comunicativa”. Esta última, de acordo com Rouanet (2000, p. 150), teria sua origem na modernidade cultural, no entanto perdeu seu espaço em meio à dinâmica social.

Essa polêmica não foi encerrada e outros autores, como Frederic Jameson (1996), de quem vamos nos ocupar, oportunamente, trouxeram novos elementos para esse debate.

O fato é que todos sentem, em seu cotidiano, uma clara consciência de ruptura. Nas palavras de Berman:

Ser moderno é encontrar-se em um ambiente que promete aventura, poder, alegria, crescimento, autotransformação e transformação das coisas em redor mas ao mesmo tempo ameaça destruir tudo o que temos, tudo o que sabemos, tudo o que somos. (2000, p. 15)

Esse sentimento acomete os indivíduos há cinco séculos, como nos lembra o autor. Porém, parece que nas últimas décadas tornou-se cada vez mais difícil lidar com a complexidade e as contradições da vida moderna.

Segundo Rouanet (2000), no fundo, há um desejo de ruptura com o mundo moderno, em virtude de acontecimentos que dão sinais de que o projeto moderno fracassou: as duas guerras mundiais, o holocausto, a crescente degradação ambiental, entre outros. A modernidade é vista, assim, como algo falido, desumano. Nesse sentido, o pós-moderno tem mais a intenção de exorcizar o velho do que articular o novo. Para o autor, trata-se de um malestar da própria modernidade. Mais especificamente, constitui uma falsa consciência, porque se trata de uma ruptura que não houve.

Para Rouanet (2000, p. 269), que se filia a Habermas, a ilusão da pós-modernidade é a tentativa de reagir às patologias da modernidade, marcada pelas utopias que não se realizaram, a razão transformada em poder, a domesticação das consciências no mundo industrializado, a tirania política e a pobreza. Tal tentativa significa uma fuga para a frente, pois renuncia ao confronto com os problemas criados pela própria modernidade.

A ilusão da pós-modernidade talvez consista no distanciamento em relação aos princípios da modernidade, como se não houvesse uma continuidade entre o passado e o presente. A negação de tal continuidade poderia ser atribuída ao sentimento de falta de ancoragem no mundo social. Esse seria um argumento a favor dos discursos que pregam tal ruptura. 
Gilles Lipovetsky ${ }^{115}$ (2006), filósofo que tem se dedicado a estudar a sociedade e o comportamento no mundo contemporâneo, trazendo alguns elementos para elucidar o processo que resultou nessa mutação histórica, coloca-se numa posição intermediária nesse debate. No seu entender, houve uma ruptura na modernidade, contudo acredita que o pósmoderno representa um desdobramento do princípio do individualismo, advindo da própria modernidade.

A modernidade e o processo de secularização tornaram possível o estabelecimento das sociedades democráticas, o desenvolvimento das ciências, o aprimoramento das instituições, entre outras conquistas, que afirmaram crescentemente os valores da igualdade e da liberdade. Tudo parecia corroborar a legitimidade do projeto moderno, que se sustentava na soberania do indivíduo sobre o meio, assim como no ideário da autosuficiência do sujeito.

No entanto, os pilares da modernidade são colocados em xeque na segunda metade do século XIX, de acordo com Joel Birman (2000, p. 190). Os pressupostos da filosofia do sujeito são questionados pelo que se denomina a descentração do sujeito. Pensadores das ciências humanas criticam a noção de auto-suficiência do sujeito, a começar por Karl Marx, que afirma que o indivíduo não é soberano, uma vez que ele é determinado pelo seu contexto histórico. Já Nietzsche aponta que o indivíduo não é a figura central de produção da verdade, deslocando para esse lugar as relações de forças entre os homens. Por fim, a psicanálise parece soterrar qualquer esperança de soberania do sujeito, com a descoberta do inconsciente. Freud demonstra que o sujeito não é movido pela razão, mas sim pelo desejo inconsciente. Com a psicanálise, o próprio termo indivíduo - indivisível - é questionado, pois, a partir de então, fica claro (ou paira a dúvida, para os incrédulos) que o sujeito é dividido entre o consciente e o inconsciente.

\subsection{O choque do novo - o movimento modernista}

Uma nova crítica ao ideário da modernidade procede do campo das artes, mais especificamente, do movimento modernista, surgido no fim do século XIX. Os artistas e intelectuais pregam uma abertura do campo das experiências, dando vazão à imaginação e aos impulsos, tendo como fim a expressão do eu. Os modernistas propõem uma ordem cultural

\footnotetext{
115 Vale marcar que estamos nos referindo ao posicionamento desse autor na obra A Era do Vazio
} (LIPOVETSKY, 2006). 
liberta da hierarquia e dos códigos estabelecidos e buscam o novo, sem qualquer amarra com a tradição. ${ }^{116}$

A Arte Moderna é subversiva, pois propõe a ampliação dos limites da arte e defende uma cultura experimental. Ela promove um rompimento com a representação clássica, por meio do cubismo, e, depois, com as inovações das vanguardas estéticas. O modernismo pretende não apenas inovar, como romper a continuidade com o passado, inaugurar uma nova ordem, em nada tributária com aquela que a antecedeu.

Ao desafiar os ditames da tradição cultural, os modernistas provocam choque no público, como a estréia, em 1913, de A Sagração da Primavera, de Igor Stravinsky, que causa repugnância e revolta nos espectadores.

Celso Fernando Favaretto (2004) alerta que, apesar de criticar a tradição, a arte moderna bebe em sua fonte. Nesse sentido, a relação que o modernismo estabelece com a tradição é de tipo dialético: o que se busca — o novo — ora complementa a tradição, ora consiste em seu oposto. A intenção é postular a idéia de começo, em oposição à continuidade. Esse começo se dá por meio da autoria do artista e da autonomia do sujeito que vê a obra de arte.

Até o cubismo, a experiência do sujeito com a obra de arte era de transcendência; a atribuição de sentido da obra se dava pela via da tradição. Com o modernismo, a experiência será de imanência, pois o sentido passa a ser singular e contingente. Dessa forma, o novo produz descontinuidade e ruptura no curso do tempo.

O alvo das críticas dos modernistas não se restringe somente à esfera da arte, como também, à ordem social. São criticadas as instituições e convenções sociais e, sobretudo, a burguesia, por seu racionalismo estreito e conservadorismo. Influenciados pelo romantismo, artistas e literatos como Baudelaire, James Joyce, os surrealistas, entre outros, defendem como princípios a exaltação do eu, a autenticidade e o prazer, valores frontalmente contrários ao ideário da burguesia, baseados no trabalho, na poupança, na moderação e no puritanismo (LIPOVETSKY, 2006, p. 63).

A burguesia foi bastante inovadora ao referenciar-se no individualismo no campo econômico e político, porém, no que diz respeito ao domínio da cultura, ela conservou a

\footnotetext{
${ }^{116}$ Cabe aqui marcar um problema em relação ao princípio inovador. Ao preconizar o novo como único valor, a arte moderna se condena a sua própria superação. Jeanne Marie Gagnebin (1997, p. 48) alerta para a questão da caducidade, presente também no projeto moderno. Identificando-se com a idéia da novidade, a modernidade adquire uma característica que a constitui e a distingue, como também, a destrói.
} 
ordem disciplinar e autoritária. Assim, o modernismo pode ser compreendido como uma extensão dos princípios modernos à ordem cultural.

Os modernistas foram enfáticos em suas críticas aos burgueses, ridicularizando seu culto ao dinheiro e ao trabalho e seu ascetismo. As palavras de ordem, segundo Lipovetsky (2006, p. 63): (eram) "Viver com o máximo de intensidade, 'desregramento de todos os sentidos', seguir os próprios impulsos e a própria imaginação...” - tais eram as reivindicações dos artistas. Tratava-se de uma postura hedonista, em clara discordância com o valor moderno de uma humanidade comum (padronizada).

A aspiração hedonista levou o individualismo a um ponto jamais visto. Ao centrar-se sobre o eu, a cultura modernista assumiu uma configuração personalista, de acordo com Lipovetsky (2006).

Para Richard Sennett (1988, p. 192), o modernismo e sua crítica à padronização mostram que seus membros desacreditam de uma sociedade disciplinar, normatizada, na qual, segundo eles, não há espaço para a singularidade. Dão início, então, a algo que vai marcar a nova ordem social: o culto à personalidade.

Sennet (1988, p. 190) mostra que tal culto se origina da racionalização do mundo, empreendido pela própria modernidade. Antes daquele processo, todos se voltavam para a eternidade e, portanto, para o transcendente. Com o advento da secularização, os indivíduos, impedidos de cultuar divindades, se voltam para o contexto imediato, centrando-se na imanência. Uma vez desmistificados os deuses, mistifica-se a própria existência. Cada sujeito examina e reflete sobre a própria experiência, no sentido de identificar o que tem de mais singular, em contraste com a experiência alheia. As impressões imediatas que cada um produz sobre si e sobre o outro vão se identificando com o que se denomina a personalidade. Vale marcar que esse processo de psicologização é acompanhado pelo processo de intensificação das experiências de interiorização, que se dá no âmbito particular, levando a uma separação entre a esfera pública e a privada.

A atenção para a personalidade foi inicialmente postulada por Rousseau, e, de certa maneira, foi impulsionada pelo romantismo, que colocou a personalidade - o eu - em primeiro plano, como no caso de Honoré de Balzac. Segundo Lipovetsky (2006), a valorização da interiorização e da subjetividade foi se traduzindo nos comportamentos e escolhas que respeitavam a própria personalidade. Como exemplo, podemos citar os casamentos por inclinação, (decididos por amor, em oposição aos casamentos por 
conveniência), a decoração dos ambientes, de forma que revelassem a personalidade de seus proprietários, etc. Como fenômeno restrito à área privada, já se via essa busca pelo respeito às singularidades, mas é com os modernistas que ela toma um vulto maior, com as manifestações de exaltação ao eu e as críticas à padronização.

\section{4 “Os Anos Loucos”}

Para Lipovetsky (2006), o movimento modernista inaugurou o processo de “personalização”, que radicalizou o individualismo para a esfera cultural, postulando o livre desenvolvimento da personalidade do sujeito, a legitimação do prazer, a liberdade de expressão e o respeito às singularidades.

Se, no início, esse movimento causou choque nos espectadores, gradativamente suas propostas foram incorporadas pelo público e o mesmo aconteceu com os valores modernistas - que foram assimilados por todos os setores da sociedade.

O processo de personalização parece ter sido um dos determinantes do declínio do dispositivo moderno de subordinação do indivíduo a regras racionais coletivas, e estabeleceu como valor fundamental a realização pessoal e o respeito às singularidades do sujeito.

Para Lipovetsky (2006, p. 63), é o surgimento do consumismo de massa, por volta de 1920, nos Estados Unidos ${ }^{117}$, que favorece a emergência do hedonismo como padrão de comportamento na sociedade. Esse período é conhecido como “Os anos Loucos”, muito bem retratado nos contos de Scott Fitzgerald.

A inovação tecnológica possibilitou a fabricação em larga escala de produtos que antes tinham um alto custo e por isso eram acessíveis para poucos. O desenvolvimento dos meios de comunicação, da publicidade e da moda e, sobretudo, o surgimento de uma nova forma de pagamento - o crédito - modificaram os hábitos e modos de vida de grande parte da população. O autor chama a atenção para o fato de que o crédito vai diretamente contra o princípio da poupança, do rigor nos gastos, tão próprios da moral puritana. A idéia do adiamento das gratificações cede lugar ao imperativo do desfrute imediato, assim os valores

\footnotetext{
${ }^{117}$ Para Lasch (1984, p. 20), a evolução do consumo deriva do desenvolvimento da indústria moderna, nos Estados Unidos, no início do século XX, e a implementação da produção em massa, por meio da linha de montagem, segundo as inovações de Henry Ford. A partir de então, os industriais voltam-se para a organização do mercado de massa e utilizam as técnicas de marketing de Alfred Sloan para criar, na década de 20, a idéia do consumo como modo de vida.
} 
do hedonismo ultrapassam o âmbito econômico e se espraiam para o cotidiano, dando origem ao culto ao ócio, ao prazer e à autenticidade.

O estilo de vida moderna advém da atitude libertadora dos modernistas, mas, em grande parte, se deve a uma nova fase do capitalismo, que derivou no consumismo de massa na década de 1920.

Para Lipovetsky (2006), a díade modernismo e consumismo de massa resultou em uma cultura centrada na realização pessoal, na espontaneidade e no desfrute. Em suma, o hedonismo tornou-se o valor central da cultura moderna. Isso nos remete ao que Jean Baudrillard (1995) chama de fun morality - o imperativo de ampliar e aproveitar ao máximo as experiências que possibilitem gratificação ou gozo.

No período que sucede a Segunda Guerra Mundial, de acordo com Lipovetsky (2006, p. 84), dá-se a revolução do consumismo, transformando completamente o modo de vida moderno. O cotidiano é ocupado por objetos, modas, imagens e informações. O consumismo acaba por corroer a ética protestante, assim como os costumes e tradições, produzindo uma cultura baseada na solicitação das necessidades individuais e das informações. Gera também uma transformação na socialização, pois cada indivíduo se ocupa do cultivo de si, levando uma vida privatizada.

De um lado, a revolução consumista liberta o indivíduo, pois o leva a viver sua vida privada de forma cada vez mais independente e personalizada, por outro, acaba por direcionar e controlar o sujeito, suas vontades e seu modo de vida.

O modernismo, por sua vez, continua atuante durante a década de 1960, mediante as críticas contra os valores puritanos e utilitaristas e as convenções, culminando com o movimento da contracultura, que, dessa vez, assume a dimensão de um movimento de massa. Porém, se essa é uma década de bastante liberação, também é o tempo em que o modernismo é absorvido pela classe média e perde seu valor de vanguarda, uma vez que suas manifestações não chocam mais, pois o hedonismo, de certa forma, disseminou-se. Outro fator apontado para a perda da virulência do modernismo é o fato de as vanguardas estéticas terem aderido ao mercado de arte.

Para Lipovetsky (2006, p. 89), o modernismo constitui um momento histórico de grande complexidade, no qual coexistem duas lógicas antinômicas. A primeira é uma lógica hierárquica e disciplinar. Na ordem política, prevalecem a centralização e a uniformização, e, na ordem social, prevalecem a subordinação, o trabalho e o esforço. A segunda lógica, que 
emerge no fim do século XIX, e que se acentua com o consumismo por volta de 1920, é uma ordem flexível, descentralizadora, diversificadora, permissiva e personalizada. Para o autor, até aproximadamente a década de 1960, predomina a lógica coercitiva e disciplinar.

\subsection{Disseminação do processo de personalização}

Após o modernismo, teria início o que Lipovetsky (2006) denomina era pósmoderna. Esta, por sua vez, corresponderia à inversão da relação estabelecida até então entre as duas lógicas, isto é, a partir de 1960, prevalece a lógica personalizadora, com dispositivos mais abertos e plurais. Trata-se de uma era em que o processo de personalização se dissemina pelas diferentes esferas, como a educação, a moda, as relações sociais e afetivas, o trabalho e a informação.

Para Lipovetsky (2006), a era pós-moderna corresponde a uma continuidade do modernismo, pois ela se caracteriza pelo prolongamento e disseminação da sua tendência constitutiva fundamental, o processo de personalização, que nada mais é do que o individualismo no seu ponto mais extremo.

De um lado, continuidade em relação ao modernismo, e, de outro, descontinuidade, pois há uma mutação histórica dos objetivos e das modalidades de socialização, tendo em vista a legitimação de novos dispositivos, mais abertos e plurais.

A chave para compreender o contexto sociocultural contemporâneo, segundo Lipovetsky (2006), é o processo de personalização. Outros autores utilizam diferentes conceitos para estudar as transformações ocorridas na segunda metade do séc. XX.

Já para Frederic Jameson, a pós-modernidade implica uma ruptura radical com a ordem anterior.

[...] tudo no ar parece confirmar a sensação generalizada de que 'os tempos modernos agora terminaram' e que alguma divisão, algum corte fundamental ou salto qualitativo, agora nos separa decididamente daquele que foi o novo mundo do início do século XX, o do modernismo triunfante. - (citado por Perry Anderson, 1999, p. 60)

Em sua obra Pós-modernismo: a lógica cultural do capitalismo tardio (1996), Jameson postula uma ruptura, tendo em vista que se trata de uma alteração na ordem econômica do capital. Para esse autor, o pós-modernismo representa a lógica cultural do capitalismo avançado. Não se trata de uma ruptura estética, como foi com o modernismo; a 
pós-modernidade vem a ser o sinal cultural de um novo período da história econômica. A partir da leitura de Anderson (1999), depreendemos que, para Jameson, o espaço cultural foi “colonizado” pela economia, ao passo que no modernismo a cultura mantinha uma autonomia em relação à esfera econômica.

A contribuição de Jameson (1996) para o debate acerca da pós-modernidade foi o estabelecimento de uma interpretação histórica de forma a articular esse fenômeno ao estágio do capitalismo multinacional, de localizá-lo no espaço e no tempo, além de examinar suas bases sociais e seu padrão geopolítico. Dessa forma, tornou-se uma referência para os estudos posteriores.

\subsection{A nova ordenação temporal}

Um dos pontos que podemos destacar da formulação de Jameson (1996), citado por Anderson (1999, p. 67), diz respeito à paisagem psíquica dessa nova era. Ela é marcada pela perda de qualquer senso de história, tanto na forma da esperança, no sentido de lançar sementes para o futuro, como na forma da memória, de maneira a criar raízes com o passado. Em outras palavras, o sujeito vive num contínuo presente. De fato, essa parece ser a única dimensão temporal que regula a vida dos jovens na atualidade, daí a dificuldade de formulação de projetos de futuro.

Apesar da relevância do estudo de Jameson (1996), acreditamos que Lipovetsky (2006) parece ir mais fundo no que tange à condição subjetiva na sociedade contemporânea, por isso optamos por continuar nos referindo à obra desse autor.

Para Lipovetsky (2006), vivemos em uma segunda revolução individualista, a que denomina narcisismo. Houve uma mutação histórica e antropológica, inaugurando uma experiência do sujeito radicalmente diferente no que diz respeito às relações consigo mesmo e com seu corpo, com o outro, com o mundo e com o tempo.

Como se sabe, Narciso consiste em um personagem da mitologia grega que era belo e orgulhoso. Certo dia, ao curvar-se para beber água de uma fonte, fica tão fascinado pela própria imagem refletida na fonte, que acaba por se apaixonar por ela e se esquece de tudo mais. Narciso deitou-se no banco ao lado da fonte e definhou, mirando sua imagem na água. De alguma forma, o personagem de Narciso remete à nova ordem social, dado o nível de 
preocupação do indivíduo consigo mesmo e com tudo que diz respeito a sua vida particular, em detrimento do mundo à sua volta.

Um primeiro ponto a ser destacado dessa ordem social denominada narcisismo é o que Lipovetsky (2006, p. 32) chama de desafeição pelas causas sociais e o direcionamento dos interesses para o âmbito privado. Na passagem da lógica hierárquica e disciplinar para a lógica flexível e permissiva, houve um gradativo declínio dos grandes sistemas de sentido, ${ }^{118}$ tendo em vista alguns fatos significativos, como a desilusão com a utopia socialista, o descrédito na ação política, o esgotamento da contracultura e o desenvolvimento do consumismo. A laicização da sociedade burguesa, isto é, a emancipação de qualquer “enquadramento transcendental”, de acordo com o autor, dá à vida privada um novo sentido, resultando no hiperinvestimento no eu.

Para Lipovetsky (2006), o declínio dos valores superiores parece não ter redundado na constituição de novos princípios, mas sim na personalização do espaço privado, que absorve tudo à sua volta, até mesmo valores transcendentais, porém de uma forma mais livre, sem um compromisso excessivo. Cada um se apropria dos valores de forma singular e o fato de aderir a algo não significa a renúncia ao seu contrário.

O que podemos observar é que, no momento em que as questões sociais são desinvestidas, o desejo, o prazer e a comunicação se convertem nos objetivos prioritários para o sujeito. Nesse sentido, as questões públicas, como a violência, ou a desigualdade social, por exemplo, mobilizam por algum tempo os cidadãos, para logo serem esquecidas, em prol das questões particulares.

A desafeição pelas causas sociais também deriva do materialismo exacerbado, decorrente da revolução do consumo, e, igualmente, do desenvolvimento da indústria cultural.

O avanço dos meios de comunicação de massa, especialmente a televisão ${ }^{119}$, redundou em uma retração da vida pública. Trata-se daquilo que Guy Debord (2000) chama de "sociedade do espetáculo", isto é, a vida parece acontecer somente se é veiculada por imagens e divulgada para o grande público. Segundo essa ótica, um fato só tem legitimidade se aparece na mídia.

No Brasil, isso chega a um nível alarmante. A evolução da televisão, desde os tempos da ditadura militar, favoreceu a restrição da vida pública e a despolitização. Neste

\footnotetext{
${ }^{118}$ Esses sistemas de sentido são as grandes narrativas ou metanarrativas às quais se refere Lyotard (1998).

119 Na última década, a internet passou a competir com a tevê, ao ocupar uma grande parte da vida privada, sobretudo para os jovens de classe média.
} 
país, de acordo com Eugenio Bucci e Maria Rita Kehl (2005), a televisão ocupa uma centralidade, pois os demais meios de comunicação, como a imprensa e o rádio, não são tão presentes como a tevê, como acontece em outros países. Aqui, segundo os autores, ela reina absoluta.

Para Kehl (2005), o usuário da televisão é, na verdade, um consumidor. Há uma produção e a transmissão intensiva de produtos, imagens e valores ligados à satisfação por meio do consumo. Nesse sentido, a produção imaginária da televisão induz ao hedonismo, pois ela apela para o desejo, e não para o pensamento.

No caso dos adolescentes, que necessitam de um reconhecimento social, o grupo cumpre esse papel. Os grupos juvenis - clubbers, punks, surfistas, etc. - são valorizados culturalmente pelo marketing, que cria produtos que representam uma senha de reconhecimento entre os adolescentes. Esses produtos são veiculados incessantemente pela televisão, tornando os jovens presas fáceis do consumo.

Ainda em relação ao consumo, Christopher Lasch (1984, p. 25) comenta que a cultura burguesa do século XIX poderia ser caracterizada, segundo a psicanálise, pelos padrões anais de comportamento, em que prevalece a contenção dos impulsos internos; valoriza-se a poupança de mantimentos e de dinheiro e o controle dos sentimentos. Já a cultura do século XX poderia ser caracterizada de acordo com o padrão oral, um funcionamento mais primitivo, em que se busca a gratificação imediata e se evita a frustração. $^{120}$

Segundo Jurandir Freire Costa (2004, p. 228), o espetáculo reordena e seleciona aquilo que merece a atenção dos usuários. Os eventos perdem a sua veracidade e são transmitidos da maneira como os proprietários dos meios de comunicação desejam. Com o pretexto de serem neutros, os mesmos adotam uma estratégia de marketing para atrair a atenção dos espectadores, no sentido de captar o público por mais tempo.

Em um primeiro momento, a mídia mostra os fatos de forma a distanciar os espectadores daqueles eventos. Isso minora a relevância do fato, como também faz com que o espectador não se implique no mesmo, pois o acontecimento se deu num lugar distante, estranho aos seus olhos.

\footnotetext{
${ }^{120}$ Vale marcar que o autor dirige seu raciocínio para a descrição do consumidor, que sacia os seus desejos por meio da aquisição de bens de consumo. O que queremos reter dessa afirmação é que o sujeito, nessas condições, percebe o mundo apenas em conexão com suas fantasias.
} 
Em um segundo momento, a moral do entretenimento e o modelo da diversão absorvem a totalidade da participação social e habituam o sujeito a se eximir de pensar crítica e eticamente, promovendo a desagregação da vida pública. Trata-se de um claro desdobramento do hedonismo, pois, cada vez mais, o trabalho de pensar e tomar uma posição em relação aos fatos é substituído pela suspensão do julgamento, em prol da diversão.

O narcisismo leva o sujeito a tomar o presente como algo absoluto, já que as causas sociais não entusiasmam mais, no sentido de mobilizar para uma transformação futura. Em relação ao passado, este perdeu seu potencial enraizador, uma vez que os laços com a tradição foram rompidos pelo modernismo. Em suma, vive-se sem uma dívida com a anterioridade e sem uma preocupação com a posteridade. Para Lipovetsky (2006, p. 33), “[...] o sentido histórico foi abandonado, da mesma maneira que os valores e as instituições sociais”. Daí a nova ordenação temporal, voltada para o presente.

O novo horizonte temporal parece ser definitivamente um marco desse novo contexto. Para Anderson (1999, p. 68):

O carregado senso do passado que caracterizara o modernismo já não existia fosse como transpiração de tradições repressivas ou reservatório de sonhos frustrados - e desapareceu a intensa expectativa de futuro - como possível cataclisma ou transfiguração - que caracterizara o modernismo.

Uma forma para compreender o arraigamento ao presente é pela via da moral hedonista e permissiva, que coloca no imediato a gratificação, sem a possibilidade de adiamento do prazer. A droga é o exemplo mais concreto de prazer imediato sem o esforço, nem o ônus do investimento e do risco. Além disso, ela provoca um estado fusional com o mundo, no qual se negam os próprios conflitos. Esse parece ter sido, no nosso caso, o motivo pelo qual Otto passou a fazer uso da maconha.

A moral do trabalho e do esforço foi desqualificada, segundo Costa (2004), em parte pelo modernismo e em parte pela moral do espetáculo, que apresenta as celebridades como modelo social e estas, por sua vez, não mostram sinais do esforço para chegar e manter-se na posição em que estão. Dão a impressão de que são talentosos e de que o sucesso é fácil, já que, nas imagens que são veiculadas pela mídia, esses indivíduos “estrelados” nunca aparecem trabalhando. Exibem sua vida privada nos momentos de lazer, sempre em meio ao luxo e o prazer, e ostentam aqueles bens de consumo que são fetichizados pelo mercado, cuja posse já indica o sucesso social de seus donos. Segundo Lipovetsky (2006), essas imagens 
insuflam a ambição pela fama e ,visto que isso é quase impossível de realizar, acaba por levar o sujeito à frustração e à certeza de seu fracasso.

Outra via para compreender a nova ordem temporal é a negação do futuro. Nos tempos da Guerra Fria, a ameaça de uma catástrofe nuclear resultou em um excessivo cultivo de si, da forma física, da saúde, etc. Quando o futuro pode ser ameaçador, parece haver um movimento de negação, e todos investem no presente, seja por meio da decoração da casa, do cuidado com o corpo, da preocupação com a saúde mental, etc.

De certa forma, o temor do porvir leva a uma retração no presente e a tentativa de eternizá-lo. Todos buscam a juventude, objetivo é esconder a passagem do tempo, que denota a aproximação do futuro. Assim, sempre é necessário rejuvenescer o corpo, seguir a moda, atualizar tudo à volta - da casa aos bens pessoais. Coloca-se, assim, o futuro entre parênteses, como totalmente distante e improvável.

\subsection{A cultura narcísica}

Um objeto emblemático para compreender o narcisismo e a relação com o presente é o corpo, o qual perdeu sua alteridade e passou a designar o que mais identifica o sujeito. $\mathrm{O}$ corpo torna-se objeto de culto e não pode mostrar os sinais do tempo. Nesse sentido, todos cultivam a forma física e recorrem a todos os meios possíveis para não mostrar o envelhecimento, que, na sociedade contemporânea, é mal visto, representando quase um sinal de decadência.

Para Lipovetsky (2006, p. 42), a centralidade do corpo no imaginário social advém do processo de personalização, que gradativamente esvaziou os referenciais políticos, morais ou religiosos de seu lastro simbólico, tornando a existência algo mais concreto e imediato, sem maiores conseqüências em relação à humanidade.

Nesse sentido, a personalização do corpo apela para o imperativo da juventude, para a luta contra a passagem do tempo e suas conseqüentes marcas físicas. O objetivo é “congelar” o corpo, de forma a não envelhecer e não evidenciar a idade, para, segundo Lipovetsky (2006, p. 43), não ter de lidar com as heterogeneidades da idade.

A tentativa de eternizar o presente se manifesta pelo culto à juventude. Desde a década de 1950, com a revolução do consumo e a disseminação do hedonismo, o jovem emergiu como o novo modelo cultural. 
A idealização da juventude por nossa cultura deriva dos valores modernistas do hedonismo e de liberdade e autonomia em relação às convenções sociais. Contardo Calligaris (2000) lembra que o adolescente, que tem anseios em fazer parte do mundo dos adultos, necessita do reconhecimento social. O reconhecimento se dá mediante o olhar de um adulto, identificando-o como adulto também. Na tentativa de obter esse olhar, o jovem procura decifrar o desejo do adulto e acaba por conseguir realizá-lo: o desejo de uma vida livre e descomprometida, marcada pelas vivências de prazer e gratificação imediata.

Nas palavras de Calligaris ( 2000, p. 57):

[...] por tentar dispensar a tutela dos adultos, a rebeldia adolescente se torna uma encenação do ideal cultural básico. Por esse motivo, as condutas adolescentes em todas as variantes se cristalizam, se fixam e se tornam objeto de imitação.

O fenômeno da juventude como modelo cultural implica uma difusão de algumas prerrogativas que antes eram restritas aos jovens para indivíduos em diferentes fases da vida: mobilidade, abertura para o novo e provisoriedade. Segundo Alberto Melucci (2004), a juventude prolonga-se para além dos limites da idade e os modos de vida sofrem uma juvenilização, sentida principalmente pela suspensão de compromissos estáveis e por certo nomadismo no tempo, no espaço e na cultura.

A idealização da adolescência leva a uma juvenilização dos adultos, favorecendo uma embaralhamento no jogo das gerações, mais especificamente, a ausência das diferenças geracionais.

O excessivo apego ao presente também coloca a cadeia das gerações em risco, pois o laço estreito em relação ao contexto imediato implica um descaso pelas gerações futuras. Um exemplo disso é a falta de consciência ecológica, de forma geral. Na sociedade de abundância (de mercadorias), em que se consome impulsivamente, o que importa é o presente e a satisfação imediata, sem pensar nas conseqüências disso em relação ao futuro ${ }^{121}$.

Para Lipovetsky (2006, p. 35), o narcisismo resulta do entrecruzamento da lógica individual hedonista, impulsionada pelo consumo, e a lógica terapêutica e psicológica, advinda do século XIX. A despolitização e o desinvestimento nas causas sociais e no espaço público cederam lugar, no imaginário social, à expansão do discurso psicológico, a ponto de este tornar-se o novo "ethos de massa".

\footnotetext{
${ }^{121}$ Talvez isso possa se modificar com a divulgação, em 2007, do relatório sobre o aquecimento global pelo IPCC - Painel Internacional das Mudanças Climáticas da ONU.
} 


\subsection{Psicologismo: a revolução interior}

A cultura psicológica toma o lugar antes ocupado pelas referências superiores. Busca-se, de todas as formas, a despadronização, almejando a livre expressão do eu, a singularização, como se esse fosse o único caminho para o bem-estar. Para Lipovetsky (2006, p. 35), trata-se de uma "revolução interior", um interesse inédito voltado para o desenvolvimento psíquico. É nesse cenário que emerge uma profusão de terapias psicológicas e toda a sorte de trabalhos terapêuticos com o fim do auto-conhecimento e da libertação do eu.

Voltando aos nossos estudos de casos, os pais de Fábio eram adeptos dessas terapias, no entanto, em vez de se entregarem verdadeiramente ao processo terapêutico (como pacientes ou como pais de um paciente), o que implica constante aprofundamento e reflexão sobre si, mostraram-se mais como consumidores, trocando de terapia como se troca a marca de um produto de consumo.

Esse psicologismo, longe de apaziguar e assegurar o sujeito, o leva a uma desorientação. Quanto mais se busca uma verdade sobre si, mais aumenta a incerteza sobre si. Freud mostrou que jamais se tem acesso a essa verdade; no mínimo, depois de um longo trabalho de elaboração psíquica, chega-se a algumas hipóteses sobre o próprio desejo. O eu, diante de tantas investigações e estímulos, perde sua aparente unidade — o sujeito descobre que a unidade é ilusória e o resultado é um desconforto ainda maior.

O pai de Otto, por sua vez, parecia sentir tal desconforto em relação à sua análise pessoal. Apesar de identificar seus problemas, não conseguia tomar uma postura proativa em relação a eles. E o pior, às vezes, fazia mal uso de elementos que descobria sobre o seu funcionamento psíquico ou do filho, em seu processo analítico, fazendo interpretações psicanalíticas descuidadas e descontextualizadas ao filho.

O psicologismo e a cultura hedonista e permissiva levam a uma constante reciclagem e investimento em si próprio, visando à liberação dos sentimentos e das energias corporais. Porém há a face negativa, de valorização de tudo que é espontâneo e autêntico, em detrimento do significado do esforço e do trabalho. Nesse contexto, as instâncias de controle social, como a escola, acabam sendo desacreditadas.

A família de Fábio parecia responder a esse padrão, pois deslegitimava a todo tempo a escola do filho, mais ainda quando esta punia o jovem. Isso ficou claro quando o pai ajudou 
o filho a fazer a prova, não reconhecendo que aquele se tratava de um instrumento de avaliação da escola e o boicotou, ignorando o processo escolar do filho e o poder de decisão da escola sobre seu desempenho acadêmico.

No que tange à escola, o descrédito atinge o reconhecimento social e a autoridade do professor. Segundo Lipovetsky (2006, p. 22), o saber do professor perdeu seu valor e concorre com a cultura juvenil, que desvaloriza o trabalho intelectual, em oposição à exaltação dos sentidos e do gozo. Educados em lares bastante permissivos, crianças e adolescentes não são capazes do autocontrole, necessário para a convivência social e para a aprendizagem. Diante da agitação dos alunos e da indiferença em relação ao saber escolar, a escola procura inovar seu currículo e abrirse para sociedade, e quanto mais atende às demandas dos alunos, mais perde seus contornos.

Esse parece ser o caso da escola onde Fábio havia estudado anteriormente, aquela do sistema de ensino. Lá era tolerado que o aluno não tivesse material escolar, não realizasse os trabalhos e não parasse em classe; apesar disso, o aluno podia ser aprovado no fim do ano. No que diz respeito ao currículo, essa escola fazia alarido de seus laboratórios de informática, parecendo investir mais no material tecnológico do que na formação de professores, no sentido de ter em seus quadros professores que fossem capazes de conter os alunos e interessá-los sobre os conteúdos ministrados.

Muitos se referem à sociedade contemporânea como a sociedade de abundância, em decorrência da revolução do consumo. Lipovetsky (2006) chama a atenção para o excesso de informações e de estímulos. A mídia transmite uma diversidade de imagens, informações e solicitações, que são logo tomadas pela obsolescência; perdem sua atualidade e, por isso, tornam-se irrelevantes. O sujeito sofre, então, uma saturação, fica apático diante da hipersolicitação. A reação em face disso é a indiferença. Ao invés de cativar, de implicar o indivíduo, o efeito é o oposto - o sujeito não adere integralmente a nenhuma referência. Um símbolo dessa postura é o ato do zapping diante da televisão.

A ética que vigora na sociedade contemporânea é a ética permissiva e hedonista; tudo que lembra rigorismo e disciplina é ultrapassado, em prol do desejo e de sua satisfação imediata. Quaisquer tentativas de centralização e direcionamento são vistos como repressivos e contrários à livre expressão do eu; cria-se uma ambiência propícia à dispersão e à superficialidade. Para Lipovetsky (2006, p. 38), é a própria organização psíquica que entra em risco. Daí a queixa constante de falta de atenção dos alunos, que representa um prolongamento da postura de espectador diante da televisão, o qual, em face da hipersolicitação, não se fixa em programa algum. Desacostumado do esforço de se concentrar 
em uma atividade, o aluno, diante de qualquer dificuldade na aula, simplesmente se desliga do que se passa na classe e faz um zapping em sua mente para algo mais interessante.

De fato, esse tipo de comportamento é freqüente na minha experiência clínica e tanto Fábio como Otto o manifestaram. De modo geral, esse é um aspecto que observo e que consiste em um objeto de intervenção de minha parte, no sentido de ajudar a criança ou jovem a adquirir um maior autocontrole, tolerância e persistência diante do esforço para realizar uma tarefa.

Ainda de acordo com Lipovetsky (2006), as instituições perderam seu prestígio com a disseminação da lógica de personalização na esfera cultural e social. Ora, de acordo com Dubet (1996b), segundo o paradigma clássico de socialização, a instituição era concebida como um conjunto de papéis e valores constituindo indivíduos e personalidades. Se a instituição perdeu sua capacidade funcional, ${ }^{122}$ por conseqüência os indivíduos ficaram destituídos de modelos de identificação.

\subsection{A destituição subjetiva}

Para Lipovetsky (2006, p. 40), a lógica personalizadora provocou o fenômeno da dissolução das identidades e dos papéis sociais. Na sociedade disciplinar e hierárquica, os papéis eram bem definidos, estabelecidos por oposições claras. Com o processo de personalização, as categorias sociais foram tomadas por uma indefinição, e esvaziadas de seu conteúdo mais estável. Isso é particularmente notado no contexto da família, em que os papéis não são mais “fixos”, assim, a mulher não se dedica apenas ao lar e o marido não é mais o único provedor da casa, entre outras transformações.

No caso de Otto, isso chegou a um ponto paradoxal: um pai que se identifica como irmão do próprio filho, e ainda mais com a anuência da mãe e dos avós.

Para Lipovetsky (2006, p. 190), o declínio da sociedade moderna pode ser percebido justamente pela erosão das identidades sociais e das normas coercitivas, em prol da liberdade

\footnotetext{
122 François Dubet (1996b) refere-se ao processo de “desinstitucionalização”, que designa a mudança fundamental do modo de produção dos indivíduos nas sociedades contemporâneas, advindo da dispersão do paradigma clássico de sociedade. Segundo o autor, a sociedade deixa de ser percebida como um sistema no qual os valores centrais são institucionalizados por alguns aparelhos; passa a ser percebida como conjuntos mais ou menos aleatórios de relações sociais e de experiências individuais. Neste sentido, a socialização, para Dubet (1996a: 15), dá lugar à experiência social, "noção esta que designa as condutas individuais e coletivas dominadas pela heterogeneidade dos seus princípios constitutivos, e pela atividade dos indivíduos que devem construir o sentido das suas práticas no próprio seio desta heterogeneidade”.
} 
e da flexibilidade na constituição de cada um, seja na esfera da família, das relações sociais, da sexualidade, da escola, etc.

Sem as balizas que configuram as identidades sociais da modernidade, o sujeito tem espaço para a livre disposição de si, porém não conta mais com as referências externas, que regulam as relações sociais. Isso abre espaço para muitos conflitos: a instabilidade na relação conjugal, na relação professor-aluno, são exemplos entre outros. Dubet (1998) fala que certas relações sofreram uma desregulação, portanto devem ser reconstruídas a cada dia.

O mito de Narciso versa sobre um indivíduo que ama a própria imagem e esse amor acaba por levá-lo à morte. Assim como Narciso, o sujeito contemporâneo vive em função da própria imagem. Tal como no processo analítico, jamais a imagem de si corresponde ao desejo do sujeito. Ao fim e ao cabo, ele sofre de insatisfação. De acordo com Lasch (1984, p. 24), o fato de o sujeito voltar-se para o cultivo de si e para a esfera privada, de início liberta a imaginação de imposições externas, porém o deixa à mercê de seus impulsos internos. Dessa forma, também a vida privada fica empobrecida. A experiência torna-se excessivamente autoreferenciada, sem o contraponto das referências culturais e sociais.

Era isso o que acontecia com Fábio. Sem a escola, ficava desprovido de modelos identificatórios, e, além disso, não tinha o espelho do outro, a lhe apontar suas potencialidades ou inadequações. Também perdia a oportunidade de encontrar nos pares marcas de identificação, a confrontação das diferenças, enfim, o estabelecimento de trocas que enriquece o processo de constituição subjetiva. Tinha apenas o olhar dos pais, a idealizá-lo.

A sociedade de abundância - de mercadorias, de solicitações, - configura-se também como uma sociedade de escassez, pois sofre da pobreza de referências simbólicas, da falta de limite ao gozo e da ausência de normas sociais, entre outros elementos. A conseqüência dessa carência é o sentimento de desorientação que marca a condição subjetiva na contemporaneidade. Um sinal disso é o mal-estar que acomete a todos, independentemente da faixa etária e da classe social, e que se tornou uma epidemia dos novos tempos. Trata-se da depressão, justamente uma perturbação do tipo narcísico, que se manifesta por meio de um sentimento de vazio, de apatia em relação ao mundo e de ausência de sentido na vida pessoal.

A incidência das patologias do agir e das condutas de recusa escolar também parecem ser uma conseqüência de tal desorientação. A intensidade e a abundância de estímulos dificultam o processo de representação e o pensamento, impedindo a elaboração simbólica dos conflitos psíquicos, levando às atuações características desses quadros. 
A condição subjetiva na contemporaneidade é marcada pela solidão, pela impossibilidade de sair da redoma que cada um construiu para si, depois de tamanho culto narcísico e investimento na esfera privada. A sensação de vazio gera angústia e leva aqueles que mais sofrem com a escassez de referências simbólicas - os jovens - à busca de emoções para sair da apatia. A música parece oferecer a pulsação que falta à vida; o cotidiano é acompanhado por uma "trilha sonora”, de preferência, no mais alto volume. Há uma profusão de aparelhos, para os quais o mercado não cessa de criar novos modelos, cada vez menores e com maior capacidade de armazenamento de músicas, feitos para o adolescente fechar-se em si mesmo, com os fones de ouvido, a qualquer hora do dia.

Outra forma de os jovens buscarem emoções é por meio das drogas, o que, para Kehl (2004a), representa um objeto de gozo e promete aplacar, pelos sentidos, a sensação de falta (que, na verdade, é simbólica).

Se a juventude se tornou o ideal imaginário da sociedade contemporânea, parece que o adolescente é aquele que está mais exposto ao imperativo da satisfação imediata da cultura narcísica, pois fica fixado ao presente e desprovido de referências para formular um projeto de futuro.

Os jovens retratados nos estudos de casos resistem a entrar na lógica do adiamento das gratificações, pois esta parece antagônica à satisfação imediata da cultura narcísica. Seus pais não parecem encontrar gratificações no mundo dos adultos, acabam boicotando as iniciativas que seus filhos esboçam no sentido de entrar na ordem escolar e se recusam a sustentar o jovem a realizar tal passagem. Na verdade, esses pais parecem ter certo gozo com as transgressões e a recusa escolar dos filhos.

Dão uma liberdade excessiva aos jovens, a qual acaba se tornando uma prisão. Esses adolescentes tornam-se reféns dos próprios impulsos. A meu ver, esses pais parecem ter uma grande ambivalência em fazer as interdições e sustentá-las diante dos filhos, assim eles resistem a marcar a diferença entre as gerações, o que daria curso à cadeia geracional.

Nesse contexto, a busca pelas emoções torna-se o único horizonte a ser vislumbrado pelo jovem. A psicanálise aponta que o gozo põe em risco a própria estrutura psíquica do sujeito. A nosso ver, a vulnerabilidade dos adolescentes parece dizer respeito a um sintoma social, de uma sociedade que idealiza a juventude e não tem dispositivos para limitar, de um lado, e de assegurar, de outro, um lugar para as novas gerações. 
Pudemos observar certas tendências no contexto sociocultural da contemporaneidade: a idealização da juventude, o psicologismo, a erosão das identidades e a dissolução das normas educativas. O adolescente, tal como Narciso, está desprovido de referências para aderir ou criticar em seu processo de constituição subjetiva - tem de se autoforjar, uma vez que os adultos estão ambivalentes em transmitir as referências culturais com as quais constituíram a própria subjetividade.

Se o contexto sociocultural parece desprovido de dispositivos para auxiliar o jovem a realizar o trabalho subjetivo decorrente das transformações da adolescência, mais do que nunca é necessário o suporte da família nessa etapa da vida.

No próximo capítulo, vamos investigar a nova configuração familiar da contemporaneidade e a influência das tendências sociais apontadas acima sobre a dinâmica da mesma, mais especificamente, em relação ao aspecto da marcação das barreiras geracionais. Também nos deteremos sobre o estatuto da lei na cultura brasileira e seus efeitos sobre a socialização, resultando na lógica do familismo. 


\section{A família afetiva contemporânea}

Nosso percurso chega, enfim, à esfera familiar, aquela que representa o locus que gesta, traz ao mundo, cuida e humaniza o bebê. A conversão da criança à cultura se faz por meio da linguagem. A criança aprende a se comunicar e, ao mesmo tempo, é inserida numa ordem simbólica: num mundo cuja ordenação é significada pela família, de acordo com as normas que estruturam a sociedade em que esta se insere.

Como comenta Cynthia Andersen Sarti (2004), a família é basicamente uma lente por meio da qual se começa a ver e a atribuir um significado para o mundo. Esse processo tem início com o nascimento e se prolonga pela vida toda, a partir dos diferentes momentos de vida do sujeito. Nesta medida, não é só a criança que aprende, que adquire novas possibilidades de compreensão e de atribuição de significado ao mundo. Esse processo é extensivo a todos os membros da família.

A família implica um universo de relações que se dá em vários níveis. No nível dos pais, há a relação horizontal entre marido e mulher. No nível da relação entre pais e filhos, segundo Sarti (2004, p. 121), esta é mediada pela autoridade, advinda da função de socialização dos menores, determinando, então, relações recíprocas, complementares e assimétricas.

Crescer na família implica também a relativização das referências familiares, bem como a adesão a novas referências, oriundas da comunidade humana externa à família. É essa passagem que vai possibilitar a subjetivação do indivíduo.

Historicamente o surgimento da adolescência representou uma dessas oportunidades de aprendizagem, de transformação da família. A adolescência levou ao alargamento dos espaços individuais, ao questionamento acerca das convicções e dos projetos dos pais, como demandou também uma reafirmação dos vínculos fraternos, posto que o jovem passou a perder sua identidade de criança e assumir um certo estatuto estrangeiro, parecendo se distanciar daquele núcleo que, até então, lhe propiciava conforto. A adolescência de um sujeito implica hoje uma adaptação estrutural da família e pode consistir em uma oportunidade de alargamento dos horizontes de cada membro desse grupo, ou o seu contrário. 
A família transformou-se com o tempo, mudando para se manter, e isso demandou aos seus integrantes flexibilidade e possibilidade de adaptar-se às transformações de cada contexto e momento histórico. Afora as transformações históricas, internamente, há também um ciclo vital da família, que hoje começa com o casamento e tem sua última etapa com os filhos adultos. Cada fase corresponde a uma crise, como afirma Ana Paula Relvas (2000, p. 52), e esta, de um lado, pode constituir um momento de mudança e evolução, e, de outro, pode representar uma perturbação da dinâmica, favorecendo a emergência de sintomas em um ou mais elementos do grupo, denunciando um mal-estar na família.

A adolescência representa, assim, um impacto na família, quando um membro passa pela transformação do vínculo infantil de relacionamento para outra forma de vínculo, mais maduro, autônomo e de menor idealização dos pais, como aponta José Outeiral (2003).

\subsection{Os adultos e sua função educativa}

Como vimos no capítulo anterior, a crescente importância dos ideais de autonomia e liberdade, impulsionados pelo processo de personalização, descrito por Lipovetsky (2006), assumiu dimensões agudas na segunda metade do século XX. Isso levou a uma nova configuração social, afetando sobremaneira a ordem familiar.

As mudanças sociais acabaram por transformar a relação entre os gêneros e entre as gerações, no seio da família. As relações passam a ser vistas numa perspectiva igualitária, repercutindo diretamente na educação das crianças e dos adolescentes.

A adolescência geralmente impulsiona o sujeito para além dos limites da família, em direção ao ambiente mais amplo. Para o jovem, significa conquistar sua autonomia, de forma progressiva, de maneira a contar, ainda, com o apoio dos pais. Para os adultos, como afirma Relvas (2000), implica a diminuição gradual do controle sobre o filho e o aumento correlativo da flexibilidade das normas familiares diante da crescente desenvoltura do adolescente, no sentido de alcançar a independência.

A ordem familiar parece ter sofrido de forma intensa essas mudanças sociais, desregulando as relações entre os membros do grupo familiar. A autoridade, que mediava e delimitava a relação entre pais e filhos, parece ter se “desnaturalizado” dessa relação. Isso foi acompanhado pelo abrandamento das barreiras geracionais, pela fragilização dos limites e das 
proibições, e pela difícil conquista da autonomia dos adolescentes. Como comenta Amaral (2006b), a fragilização das normas tem se refletido no aumento da dependência mútua e das exigências narcísicas.

Dentre as transformações recentes no seio da família, podemos destacar as mudanças nos lugares ocupados, como também as duas diferenciações básicas nas relações humanas, que são estruturadas na própria vivência familiar: a diferença dos sexos e a das gerações. A afirmação das diferenças possibilita aos filhos a disposição para as relações afetivas diferenciadas e a constituições de modelos identificatórios amparados nesses dois eixos das relações humanas.

Vamos nos ater sobre a diferença do lugar geracional, que consiste no tema por essência de nossa investigação. Essa diferença coloca os pais diante da autoridade inerente à função educativa, que percorre toda a formação da criança e do adolescente, bem como sua organização psíquica.

Os pais educam seus filhos para a vida comum, para o mundo. Para Hanna Arendt (1997), o mundo é concebido como o legado das realizações humanas: a cultura, os valores, as normas, as instituições sociais, etc. Nesse sentido, os adultos têm uma responsabilidade pelo mundo, a qual advém da necessidade de preservar o legado cultural. Na educação, a responsabilidade pelo mundo é representada pela autoridade.

A psicanálise, como mostra Mezan (2002, p. 267), nos ajuda a compreender como se dá o processo de inserção da criança ${ }^{123}$ na vida comum. A criança nasce em uma coletividade, incorpora, introjeta e absorve os valores, normas, jeitos de viver dos adultos à sua volta, de forma a tornar-se um membro daquele grupo. É mediante as identificações que o sujeito incorpora, toma para si os modelos que a sociedade oferece e se torna um membro desta. $\mathrm{O}$ sujeito pode até mesmo criticar tais modelos, ${ }^{124}$ mas seu processo de pertencimento à comunidade se dá a partir desse repertório comum de significações coletivas.

A autoridade do adulto consiste em apresentar o mundo à criança e, simultaneamente, coibir seus impulsos agressivos, no sentido de preservar o mundo. Em compensação, o adulto mostra à criança os meios de canalizar seus impulsos para formas mais

\footnotetext{
${ }^{123}$ Ao utilizarmos o termo criança, estaremos nos referindo a todos os sujeitos que estão inseridos no processo educativo, independente de sua faixa etária. Quando nos referirmos especificamente a adolescentes, utilizaremos o termo adolescente.

${ }^{124} \mathrm{~A}$ adolescência consiste na etapa por excelência em que o jovem se abre para o mundo e tem a possibilidade de entrar em contato com outras formas de ser e de viver, podendo, assim, tomar um distanciamento crítico em relação aos modelos familiares.
} 
socializadas de satisfação, por meio da fruição cultural. Ao submeter-se às normas e aos modelos culturais, a criança assume sua dívida simbólica em relação às gerações anteriores.

A educação guarda, então, duas funções: a de defender o mundo das crianças, por meio das interdições e normas sociais, e a de apresentar múltiplas possibilidades de sublimação, por meio da fruição cultural. Do lado do adulto há o exercício da autoridade, legitimado em sua responsabilidade pelo mundo, e, do lado da criança e do adolescente, há a renúncia pulsional e a canalização dos impulsos para a cultura, para o mundo das realizações simbólicas.

Freud mostrou, de forma magistral o processo de inserção do sujeito na coletividade e os sacrifícios que isso implica, em Totem e Tabu. Vamos retomar alguns pontos dessa obra para avançar em nossa discussão sobre a autoridade.

\subsection{Do laço pessoal e familiar para o laço social}

Em Totem e Tabu, Freud (1913) traça um cenário mítico, no sentido de proclamar a universalidade do complexo de Édipo. Na verdade, trata-se de um exercício de uma antropologia mítica. Ao retomar esse cenário mítico, acaba chegando ao complexo que lhe deu origem: o complexo de Édipo; e, ainda, lança as bases para a noção do ideal de ego. ${ }^{125}$ Nessa obra, Freud não só constrói um conceito que fundamenta a "psicologia individual”, como algo essencial para a compreensão da “psicologia coletiva”.

A cena mítica inicial corresponde à horda primitiva descrita por Darwin, onde vigora a ordem parental. O pai é o chefe; protege os filhos dos perigos externos, mas é também tirânico, exigindo para si o direito sobre todas as mulheres. O despotismo paterno revolta aos filhos. Certo dia, estes se reúnem, matam e devoram o pai, realizando uma refeição sacrificial. Ao devorar o pai, identificam-se com o mesmo e incorporam uma parte da sua força. Para Freud (1913, p. 170), essa refeição marca o início da organização social, das restrições morais e da religião.

Após o crime, os filhos sofrem pela culpa, pois o amor pelo pai, até então recalcado, se faz presente. Instituem, assim, o pai como totem ${ }^{126}$ da horda. Em vez de usufruir das

\footnotetext{
${ }^{125}$ Conceito que mais tarde viria a constituir a instância do superego.

${ }^{126}$ Nas palavras de Freud: “o totem é o antepassado comum do clã; ao mesmo tempo, é seu espírito guardião e auxiliar” (1913, p. 21). Em compensação, os integrantes têm certas obrigações para com essa figura: não podem
} 
mulheres que agora estavam à sua disposição, os filhos decidem proibir o parricídio e renunciar às mulheres da tribo. Estabelecem, então, a regulação das trocas sexuais.

Nas palavras de Freud (1913, p. 172): “Criaram, assim, do sentimento de culpa filial, os dois tabus fundamentais do totemismo, que, por essa própria razão, corresponderam inevitavelmente aos dois desejos reprimidos do complexo de Édipo”. A saber: os tabus do incesto e do parricídio. A horda parental dá lugar à horda fraterna.

A renúncia pulsional passa a ser a condição para a vida em uma coletividade. Em troca, todos têm a proteção e o amparo que esta oferece (e que antes era proporcionada pelo pai).

Freud postula tanto os interditos que alicerçam o pacto social, como aquilo que estrutura a própria mente humana - a ambivalência emocional no complexo parental. Isto é, a existência de amor e de ódio para com os mesmos objetos. Para Freud (1913, p. 186), ela é fundamental na vida emocional e também está na raiz das instituições culturais. ${ }^{127}$

Esses dois pólos estão presentes tanto na psique do indivíduo como na psique social. O que parece conectar o individual ao social é o superego - o pai mítico que está inscrito no sujeito pela vivência do complexo do Édipo — como comenta Birman (2000).

O superego é uma instância social e individual. Como se sabe, o superego é herdeiro do complexo de Édipo; a criança renuncia à satisfação dos desejos incestuosos, atingidos pela interdição, e transforma o investimento nos pais em identificação com os mesmos. Assim, o superego é social, posto que veicula as interdições e normas da sociedade e, ao mesmo tempo, é uma instância individual, pois está articulada a uma triangulação edípica singular.

O superego não é constituído apenas pelas interdições, como também pelos ideais coletivos. Kehl (2000) lembra que a culpa pela morte do pai pode ser reparada pelos ideais sociais, os quais trazem marcas do pai fundador.

Como comenta Dany-Robert Dufour (2005, p. 159), nessa obra, como em outras do mesmo cunho, ${ }^{128}$ Freud tem a oportunidade de apresentar duas redes conceituais, uma que estuda as ressonâncias do complexo de Édipo em relação ao laço pessoal e familiar, e outra que articula esse conceito a uma teoria da cultura e do laço social.

matá-lo nem comê-lo, pois muitas vezes o totem é um animal. No entanto, nas refeições sacrificiais, todos os membros do clã estão presentes e podem comê-lo. De forma geral, uma obrigação que acompanha o sistema totêmico é a lei que proíbe as relações sexuais entre indivíduos da mesma coletividade totêmica.

${ }^{127}$ A ambivalência emocional retratada em Totem e Tabu mais tarde Freud (1920) formaliza como a dualidade pulsional, mais especificamente, as pulsões de vida e de morte.

${ }^{128}$ Podemos citar: Psicologia de grupo e análise do ego, O mal-estar na civilização e Moisés e o monoteísmo. 
Birman (1994) assinala que não há uma oposição entre o indivíduo e o social, mas sim entre "atos psíquicos sociais e narcísicos", ${ }^{129}$ dependendo, assim, do campo em que se inserem os objetos possíveis de satisfação no circuito pulsional.

A cultura veicula interdições, como também oferece formas de canalizar as pulsões para algo construtivo, valorizado socialmente, por meio da sublimação. Como comenta Mezan (2002, p. 368), a cultura deve estimular e controlar a agressividade (para não ser objeto da mesma). A forma de estimular seria pelas competições, jogos físicos, intelectuais, teatro, enfim, formas de manifestação da agressividade de maneira a dirigi-la para um fim coletivo.

A palavra “cultura”, como mostra Hanna Arendt (1997, p. 265), vem da raiz latina colere: cultivar, habitar, tomar conta, criar e preservar. A cultura não tem, assim, do ponto de vista etimológico, apenas o lado repressivo, de veicular as proibições. Para Mezan (2002), a cultura comporta um lado sedutor, que oferece meios de fruição e satisfação. Portanto, as interdições fazem parte dos conteúdos da tradição cultural, entre outros tantos legados.

\subsection{Autoridade e responsabilidade pelo mundo}

A autoridade na educação advém, segundo Arendt (1997, p. 235), de duas necessidades: a necessidade natural, pois a criança necessita de alguém que cuide dela, que a proteja, e a necessidade política: o patrimônio cultural precisa ser protegido para não ser destruído pelas novas gerações. ${ }^{130}$

Quando ocupa o lugar da autoridade, o adulto transmite as normas sociais e o legado cultural para a criança. Faz isso em nome do seu compromisso social, e não em nome do próprio desejo. Arendt (1997) lembra que a criança, ao ser introduzida ao mundo, chega a um universo que é preexistente às novas gerações e que deve ser zelado pelos adultos, para garantir a continuidade da civilização.

A ausência de autoridade, de limites à criança, bem como a transmissão das referências culturais, dá a sensação a ela de que os pais não podem protegê-la. Fica à mercê

\footnotetext{
${ }^{129}$ Ele faz referência a Freud, em Psicologia de grupo e análise do ego (1921).

${ }^{130}$ A autora não quer dizer com isso que a cultura deva ser estática - ela pode e deve ser renovada - desde que seus fundamentos permaneçam acessíveis às novas gerações.
} 
dos próprios desejos e ambivalências, sem referências para regulá-los, projetá-los no futuro e atribuir-lhes um significado.

Jeammet (2007, p. 77) demonstra que a conquista da liberdade de uma criança depende da própria capacidade de esperar, de postergar as gratificações. Quando o adulto estabelece limites e a criança renuncia aos seus impulsos, curvando-se às normas, ela tem como recompensa o afeto e o reconhecimento do adulto. Num primeiro momento, a capacidade de esperar implica a satisfação adiada, tendo em conta a aprovação dos adultos, e a possibilidade de autocontrole da criança. Posteriormente, a criança adquire maior liberdade, tanto em relação às próprias necessidades, pois agora pode controlá-las, como em relação aos afetos daqueles que estão à sua volta.

Difundiu-se nos anos sessenta uma idéia de que o exercício da autoridade entre adultos e crianças deve ser atrelado à argumentação. Arendt (1997, p. 129) demonstra que esse exercício diz respeito à persuasão, situação que se estabelece entre iguais, e implicaria o desaparecimento da diferença que existe entre as gerações. Essa é mais uma das idéias que foi largamente disseminada na educação moderna, assimilada pelas escolas e pela sociedade, resultando na suspensão da autoridade, como adverte a autora.

A lógica de personalização, descrita por Lipovetsky (2006), levou à erosão das identidades sociais e das normas coercitivas. Uma conseqüência disso é que os modelos identificatórios parecem cada vez mais difusos, dificultando a inserção dos mais jovens ao mundo da cultura.

Nesse sentido, caberia aqui um aprofundamento sobre a configuração do núcleo familiar na atualidade na perspectiva da psicanálise. Assim poderemos contar com mais elementos, tanto sobre os laços dos adultos com as referências culturais, como sobre a disposição destes em assumir ou não o seu lugar na linhagem geracional.

\subsection{Um breve histórico sobre a família}

A historiadora e psicanalista Elisabeth Roudinesco (2003), em seu estudo sobre a família em uma perspectiva histórico-cultural, A família em desordem, descreve o processo de transformações ao longo do tempo na família no Ocidente, até chegar às complexas configurações assumidas pela família na contemporaneidade. 
Apoiando-se em Lévi-Strauss, a psicanalista francesa parte do pressuposto de que as relações de parentesco são universais, se encontram em todas as sociedades humanas. A família se estruturou, ao longo da história, sobre duas ordens: uma biológica, que repousa na diferença entre os sexos e estabelece o que o antropólogo denomina a lei da aliança, e outra ordem, simbólica, que repousa na proibição do incesto e estabelece a lei da filiação.

Como aponta Roudinesco (2003, p. 18), o termo família pode referir-se a diferentes realidades. Na Idade Média, por exemplo, ela era entendida em um sentido extensivo significava pai, mãe, filhos, parentes, servos e agregados. A família nuclear moderna emergiu após um longo período de gestação (século XVI ao XVIII).

Roudinesco (2003) traça um amplo panorama histórico da família, do qual vamos reter apenas suas linhas gerais. O primeiro período se refere ao modelo da família patriarcal, modelo que se manteve por séculos, declinando com o advento da modernidade. Nessa configuração, a ordem social era vista como algo sagrado e imutável; vigorava o casamento por conveniência, no qual o objetivo era assegurar a transmissão do patrimônio. Este modelo se estruturou sobre a autoridade patriarcal: o pai exercendo seu poder absoluto sobre a mulher, a prole, os servos e os agregados.

O segundo período diz respeito à dita família nuclear moderna e, segundo vários autores, esse modelo se impõe por volta do séc. XVIII. Nesse contexto, a família é regida por uma lógica afetiva e a aliança se baseia na satisfação sentimental e amorosa. O poder parental é então dividido com o Estado, que impõe limites ao pátrio poder.

Por fim, esse último modelo evolui até que, num momento que pode ser situado por volta de 1960, passa a corresponder ao modelo da família contemporânea: o exercício da autoridade parental diminui, graças às rupturas da família em virtude do trabalho assalariado feminino, dos divórcios e novos casamentos.

A partir dessas linhas gerais, observamos que, ao longo da história, a família sofreu uma grande transformação em sua estrutura. Se nos primórdios da civilização ocidental a família era arraigada nas tradições e rigidamente hierarquizada, nos quase últimos três séculos, adquiriu uma estrutura horizontal e igualitária. Ao fim desse processo, percebe-se que houve uma humanização nas relações familiares, no entanto a questão da autoridade tornou-se bastante difusa e problemática, destacando-se o declínio da autoridade da figura paterna, tema que se tornou quase um leit-motiv na psicanálise atual. 


\subsection{Um novo olhar para a autoridade parental}

Nas sociedades ditas tradicionais, a figura paterna adquiria um status privilegiado. $\mathrm{O}$ pai tinha ascensão sobre todos os membros da família. Com o Iluminismo e a propagação dos ideais revolucionários, a autoridade do pai é relativizada. A partir de então, de acordo com Roudinesco (2003, p. 31), sua autoridade se baseia em um contrato moral e social. O pai torna-se mais terno com seus filhos, tomando-os como objetos de afeto e atenção.

A sociedade moderna, segundo a sociologia clássica, funciona como um sistema em que os valores centrais são transmitidos pelas instituições e, por meio destas, o indivíduo se subordina à sociedade. Simultaneamente, o sujeito incorpora valores, normas e funções sociais. Nesse modelo, a família cumpre um papel fundamental na integração funcional, constituindo um dos pilares da sociedade burguesa, como comenta Roudinesco (2003, p. 39).

Na constelação da família moderna, o pai ocupa o lugar do chefe, ainda que um chefe com feições mais humanizadas. Se os ideais revolucionários deram início a uma progressiva desmistificação da figura paterna, é verdade que eles também insuflaram um movimento complementar - o da supressão das diferenças sexuais, melhor dizendo, das diferenças de gênero compreendidas como dominância do homem sobre a mulher.

É nesse contexto cultural que Freud, atento ao papel secundário da mulher na sociedade, apresenta, no início do século XX, sua formulação acerca do Complexo de Édipo. Em um só tempo, reconhece não só as diferenças entre os sexos, como restabelece, de certo modo, a autoridade paterna, entendida, a partir de então, do ponto de vista simbólico.

Como diz Roudinesco, no lugar do pai soberano, a psicanálise coloca o inconsciente e a lei. ${ }^{131}$ A figura paterna não é mais associada ao poder divino, mas a uma inscrição simbólica, a função paterna.

Nas palavras de Roudinesco (2003, p. 90), Freud cria uma estrutura psíquica do parentesco que institui o desejo sexual no núcleo das leis da aliança e da filiação; é a diferença dos sexos e das gerações, organizada em torno do e pelo casal parental. Além de inaugurar a

\footnotetext{
${ }^{131}$ Vale assinalar que o termo lei foi usado por Freud em Totem e tabu (1913, p. 172): “Assim, os irmãos não tiveram outra alternativa, se queriam viver juntos - talvez somente depois de terem passado por muitas crises perigosas -, do que instituir a lei contra o incesto (...)”. No entanto, Freud costuma utilizar os termos interdição e proibição ao referir-se ao parricídio e ao incesto. Já Lacan se refere à instância interditória pelo termo lei.
} 
noção do desejo, Freud introduz também a noção da culpa, advinda do desejo do filho pela mãe e do seu desejo de matar o pai.

Ao descrever a família edipiana, Freud mostra a estrutura familiar como o núcleo de onde emergem as neuroses, mas ela é também espaço de rebelião, de constituição da subjetividade. Para Roudinesco (2003, p. 91), a família submete o filho à interdição, ao logos que separa a criança da mãe ${ }^{132}$ e também mobiliza no sujeito o desejo de ultrapassar a ordem familiar.

Para Freud, a cultura favorece tanto formas de canalização das pulsões para meios mais construtivos, por meio da sublimação, como também propicia ao sujeito o contato com modelos identificatórios distintos da família, ampliando as possibilidades de subjetivação.

A tese central do estudo de Roudinesco é que a psicanálise dirigiu um novo olhar para a mulher e a criança no interior da família. No que diz respeito à primeira, Freud a vê em seu duplo estatuto: mãe, mas também uma mulher, um ser desejante. A partir da difusão da psicanálise, segundo essa autora, a mulher se vê valorizada nesse duplo estatuto e começa a aspirar a outras coisas, além do papel materno. Busca, assim, novas formas de se realizar individualmente. Quanto à criança, esta é colocada no lugar de sujeito, com sua singularidade.

Roudinesco (2003, p. 101) comenta, ainda, que a autoridade do pai é exercida a partir da perspectiva que respeita o lugar de cada um na constelação familiar.

A ordem simbólica da função paterna vigora por mais de meio século e entra em declínio em virtude das transformações advindas do processo de personalização, como vimos em Lipovetsky (2006), as quais levam a uma redefinição dos papéis de autoridade, engendrando um novo modelo familiar.

A psicanálise é, em certo sentido, a precursora dos ideais da família afetiva contemporânea, pois, de certa forma, engendra a família nuclear afetiva, uma vez que coloca na base da estrutura familiar uma relação conjugal entre homem e mulher em que é necessário haver amor e desejo. Outro pressuposto é que nesta relação ambos podem se desenvolver como sujeitos.

\footnotetext{
${ }^{132}$ A idéia de um logos separador vem de Thomas Hobbes, que defende que a passagem do estado da natureza ao estado político advém da autoridade do pai, o qual tira o filho de uma indiferenciação com a mãe, situação correspondente àquele primeiro estado, de acordo com Roudinesco (2003, p. 28).
} 


\subsection{A família afetiva contemporânea}

Por volta de 1960, período em que a lógica da personalização se dissemina na esfera cultural e social, na acepção de Lipovestky (2006), a família, assim como outras instituições, sofre uma verdadeira metamorfose. Dentre as mudanças sociais, podemos marcar a emancipação da mulher. O advento dos anticoncepcionais dá origem a uma percepção mais espontânea do casamento, dissociando o desejo sexual da procriação.

O avanço da sociedade de consumo leva a mulher a entrar no mercado de trabalho para aumentar a renda familiar e poder usufruir os bens de consumo. Nesse sentido, compartilha o sustento e a autoridade da família. A liberdade individual se impõe no casamento e este é tomado pela instabilidade.

O casamento perde sua “sacralidade”, sendo objeto de constante questionamento. Os divórcios, que antes constituíam exceção, tornam-se cada vez mais freqüentes, transformando o casamento em um contrato de duração relativa, em que os cônjuges buscam a realização amorosa e sexual e rompem-no quando este não mais propicia tal realização. Vemos aí marcas do processo de desinstitucionalização de que fala Dubet (1996b).

As famílias tomam novas configurações: famílias recompostas, dando origem a uma educação co-parental, e até mesmo monoparental (em sua grande maioria, o chefe da família é uma mulher). O núcleo familiar torna-se uma estrutura de poder descentralizado e de múltiplas configurações, como as famílias recompostas e as famílias advindas de uniões homossexuais (inclusive com filhos - frutos dos avanços na procriação assistida e também de adoções). Emerge, então, um novo padrão de convivência, bem como de modelos identificatórios para as novas gerações, advindos da família contemporânea.

Nesse percurso histórico esboçado por Roudinesco (2003), observamos que a autoridade passa de uma ordem simbólica, advinda da função paterna, para uma ordem cada vez mais abstrata e difusa. Houve uma redefinição das posições de autoridade e esta passou a ser mais compartilhada, em prol de uma dinâmica familiar mais humanizada (Roudinesco, 2003). No entanto, notamos que o exercício da autoridade de forma mais democrática deu margem ao apagamento da diferença geracional.

Retomando Arendt (1997), a autoridade se fundamenta na responsabilidade dos adultos pelos seus filhos e pelo mundo. Para proteger as crianças do mundo e vice-versa, os adultos necessitam transmitir-lhes as normas. 
A interdição do incesto institui o princípio da diferença - diferença entre as gerações, entre os sexos, entre pais e filhos, etc. Ao mesmo tempo em que estabelece a diferença, faz de todos os indivíduos seres semelhantes, posto que todos seguem a mesma norma.

Para Roudinesco (2003, p. 129), a família, no sentido freudiano, tem um caráter trágico, na medida em que todos os membros agem inconscientemente como heróis trágicos, assim como Édipo. São guiados por desejos incestuosos e de morte e só escapam de seu terrível destino se renunciam aos seus impulsos e se sublimam suas pulsões, mediante a submissão à proibição do incesto e do parricídio.

Como é difícil para as crianças abdicarem da satisfação das pulsões, o adulto tem de reprimir tais impulsos e oferecer algo em troca, na forma da sublimação. Tal processo é antinatural, trata-se de um fato cultural, que se dá mediante um adulto que assume a posição assimétrica e se coloca ao lado da cultura. É esta que faz valer o pacto social.

\subsection{Os modelos identificatórios}

Para a psicanálise, é por meio das identificações que o sujeito se integra à sociedade, adere às referências que a fundamentam. Como comenta Mezan (2002, p. 268), essas referências correspondem aos padrões sociais, valores, leis, formas de autocontrole, enfim, à tradição, que é renovada progressivamente. Os modelos são encarnados pelos indivíduos e pelas instituições e constituem ideais a serem seguidos pelos novos membros daquela sociedade. Por isso são chamados modelos identificatórios.

Como apontam Laplanche e Pontalis (1985, p. 295), a identificação consiste numa operação inconsciente em que o indivíduo se identifica com o outro e assimila um traço deste, conformando-se a partir desse modelo. Na verdade, essa operação tem um cunho constitutivo - o sujeito se constitui por meio de uma série de identificações.

O caráter constitutivo das identificações implica atos psíquicos que possibilitam ao Eu uma auto-representação, um pólo estável dos investimentos que constituem "seu espaço, seu capital e seu mundo relacional”, como observa Piera Aulagnier (1990, p. 187).

Como vimos em Sobre o narcisismo (1914), esse processo se inicia pelo investimento no próprio ego, e depois o investimento recai sobre os objetos de amor - as 
figuras parentais. Por ocasião dos efeitos estruturais do complexo de Édipo, dá-se a diferenciação do aparelho psíquico, resultando nas instâncias psíquicas: id, ego e superego, o ideal de ego e as imagens parentais. Os investimentos nas figuras paternas são abandonados, dando lugar às identificações. Posteriormente, o sujeito se identifica com "outras pessoas colocadas em posição de autoridade”, como afirma Freud (1923, p. 52).

Para Mezan:

[...] é na região do narcisismo, do ego e das instâncias ideais, como o superego e o ideal de ego, que [...] operam os mecanismos [identificatórios]. Eles devem ser - e, empírica e historicamente, têm sido - suficientemente fortes para constituir uma maioria de sujeitos viáveis, capazes de funcionar na sociedade em questão e de perpetuar a existência dela; ao mesmo tempo, suficientemente flexíveis para possibilitar as diversidades individuais, os diferentes modos de ser "eu" que correspondem ao espectro próprio àquele determinado e específico grupo. (2002, p. 268)

Parafraseando Arendt (1996), para sobreviver, uma sociedade necessita transmitir o seu tesouro aos mais novos, apontar uma forma de viver e de compreender o mundo própria da sua cultura. Esta corresponde a um conjunto de significações que possibilita a constituição da subjetividade e a atribuição de sentido aos seus descendentes. Esse processo nada mais é do que a educação.

Cada sociedade dispõe de certo repertório de modelos com os quais o indivíduo pode se identificar. A escolha de referências depende das disposições do sujeito, resultantes das suas experiências, da forma como se constituiu psiquicamente.

Do entrecruzamento entre os modelos que determinam o indivíduo e das disposições que ele próprio determina, resulta o processo de subjetivação. Para Dubet e Martuccelli (1996), esse processo consiste em um jogo de adesão e de distanciamento crítico do indivíduo em relação a essas modalidades de aculturação. É um trabalho do sujeito, uma elaboração por meio da qual ele constrói uma identidade, uma coerência e um sentido.

A adolescência marca justamente a passagem das identificações advindas do mundo familiar para as identificações referentes ao mundo social. Para Marcelli e Braconnier (2007), as apropriações identificatórias dependem dos objetos mediadores, e isso começa pelos laços mais primitivos com as figuras parentais. É necessário que os modelos identificatórios sejam bem ancorados e relativamente integrados. 
Como comenta Bernardo Tanis (2001), a família se caracteriza por um sistema de parentesco que se estrutura por lugares simbólicos e, de forma geral, estes são sustentados por um discurso (ou uma cultura) que organiza e legitima esses lugares.

As mudanças sociais nas últimas décadas acabaram por transformar esses lugares simbólicos. Até por volta dos anos sessenta, como também salienta Kehl (2001), havia uma tradição que dizia como deve ser o pai, a mãe, um homem, uma mulher, um adolescente, etc. No entanto, esses modelos já não se sustentam socialmente, eles não mais correspondem aos modos de vida atuais. Não há mais formas culturais que legitimem esses lugares simbólicos ou modelos identificatórios.

A sustentação simbólica dos modelos identificatórios é sempre referendada aos ideais sociais. Se os antigos ideais perderam a legitimidade, a nova versão dos ideais de igualitarismo e de individualismo, como demonstra Lipovetsky (2006), parece ter gerado uma desorientação.

Os adultos ficam, então, desconfortáveis em relação aos próprios papéis e ideais e transmitem essa ambivalência aos filhos. Os pais parecem não dispor de valores e ideais consistentes a serem transmitidos às novas gerações. Segundo Dufour (2005), não sabem em nome de quê educam. As antigas referências lhes parecem ultrapassadas, assim eles se negam a assumir a sua posição na linhagem geracional, ao que o autor denomina negação geracional (DUFOUR, 2005).

Os jovens ficam, então, sem uma anterioridade. As novas gerações se encontram numa situação insólita: estão desprovidos de referências éticas para se situarem no mundo adulto, assim como de parâmetros para se constituírem como sujeitos.

A tradição da família afetiva, até por volta da década de 1960, propiciava uma certeza subjetiva na maneira de educar os filhos e esta era sustentada pela família extensa e pela comunidade. É claro que havia desvios, exageros, como o próprio Freud demonstrou essa família era o núcleo das neuroses - e foi em nome dessa crítica feita pela psicanálise, em parte, que esses padrões foram questionados e transformados.

Em relação às normas, os adultos atualmente são permissivos, com o argumento de proporcionarem o livre desenvolvimento dos filhos. Entretanto, ao se negarem a estabelecer parâmetros aos mais jovens, acreditando que eles podem discernir em relação a diferentes situações, se desresponsabilizam pelo cuidado com as novas gerações. Em outras palavras, se colocam como iguais e se demitem de sua função educativa. 
A nosso ver, a fragilização dos limites, a ambivalência dos adultos em exercer a autoridade, em fazer valer as interdições e a necessária renúncia pulsional que estas acarretam, parece corresponder à outra face da falta de contornos dos modelos identificatórios.

Essa ambivalência diante das normas assume um caráter ainda mais agudo na realidade brasileira. Temos certos padrões irregulares de sociabilidade, decorrentes de nossas raízes colonialistas e escravocratas. A forma como o brasileiro lida com a lei, com as normas que regulam a vida comum, parecem não ter sido estruturadas no campo dos direitos, mas, sim, no dos privilégios.

Vamos nos debruçar agora sobre a realidade brasileira e a forma como a família de classe média se relaciona com as normas. Sérvulo Augusto Figueira, psicanalista, realizou um estudo interdisciplinar junto aos pesquisadores do Museu Nacional do Rio de Janeiro, coordenado pelo antropólogo Gilberto Velho, a respeito do contexto da modernização do Brasil e a constituição de uma cultura psicanalítica que se disseminou pelos centros urbanos brasileiros por volta das décadas de 1960 e 1970. Figueira tem contribuições bastante significativas para a compreensão da família contemporânea brasileira, da sua relação com a lei, assim como da forma como se configurou no país a relação entre o público e o privado.

\subsection{A família de classe média brasileira: o mergulho no novo}

Concordamos com Figueira (1992), quando ele afirma que a realidade brasileira não pode ser deduzida de estudos realizados nas chamadas sociedades complexas. Apesar de o fenômeno da globalização disseminar mudanças em todo o mundo, há algumas especificidades em nosso contexto histórico-cultural que deixaram marcas profundas em nossa sociedade.

Tomando por base alguns autores fundamentais para compreender a sociedade brasileira, como Gilberto Freyre, Sérgio Buarque de Holanda e Antonio Candido, Figueira nos alerta para a singularidade do Estado e da lei na cultura brasileira.

Figueira (1992) chama a atenção para o desejo de modernização que sempre marcou o Brasil e a elite brasileira. Podemos considerar isso como uma herança colonial, de querer 
imitar a metrópole, de ser como o outro. A modernização, a partir da abolição do escravismo, se deu a qualquer preço, mantendo-se a estrutura básica de diferenças agudas entre grupos e classes sociais, e acrescentando-se a esse fundo elementos modernos. O fato é que diferentes processos de modernização, na sociedade brasileira, ocorreram quase sempre por justaposição, resultando em um híbrido entre o arcaico e o moderno. Essa idéia é próxima à de Henri Lefebvre, citado por Spósito (2000), que fala da simultaneidade de diferentes tempos sociais, assim, no Brasil, convivem diferentes realidades, diferentes temporalidades. E o mesmo pode ser afirmado em relação aos valores — o tradicional e o moderno coexistem no mesmo sujeito.

Tratando de modernização, Figueira (1992) comenta sobre o processo de mudanças econômicas empreendidas durante o governo de Juscelino Kubitschek, na década de 1950, e que praticamente mudaram a cara do nosso país. A onda de industrialização e consumo revolucionou os costumes e valores da família brasileira. O modelo patriarcal, de estrutura hierárquica, que estava tão enraizado, em pouco tempo cedeu ao modelo moderno, de estrutura igualitária. No caso das famílias de elite e de classe média de grandes centros urbanos, ${ }^{133}$ havia uma conduta orientada pelo novo, mas, subterraneamente, pulsava toda uma formação tradicional.

Esse comportamento da elite de consumo imediato e sumário de posturas, costumes e idéias, sem uma verdadeira sedimentação, foi muito bem retratado por Machado de Assis, em Memórias póstumas de Brás Cubas, como aponta Roberto Schwarz (1990). Schwarz alerta que a postura "novidadeira” vem sempre acompanhada da volubilidade, pois a adesão a um ideário cede logo lugar a outro. O modelo que vigorara até então logo é desqualificado.

Segundo Figueira (1987), não se moderniza assim, de imediato. A sociedade se modernizou, de certo modo, apenas nas aparências com o processo de industrialização. Na rápida urbanização das cidades, grande parte da população ficou excluída desse processo, continuando a viver na miséria, antes no campo, agora na periferia dos grandes centros urbanos. ${ }^{134}$ Da mesma forma, sem transformações na estrutura social, não se torna possível para um indivíduo abandonar realmente verdades que sempre direcionaram seus valores e condutas. A modernidade fica, assim, na camada mais superficial do sujeito. Representa seu

\footnotetext{
${ }^{133}$ Figueira procura ser bem específico, tentando situar tal fenômeno na cidade do Rio de Janeiro, porém a realidade dos grandes centros urbanos brasileiros não difere tanto assim.

${ }^{134}$ De acordo com Eric Hobsbawn (1995), de 1960-1980, a população rural se reduziu quase à metade, migrando para as cidades grandes.
} 
traço visível. No entanto, nas camadas ditas invisíveis, pulsam um modelo e um ideal arcaicos.

Como relata Figueira, diante da mudança de cenário à sua volta, logo as famílias da elite e da classe média procuraram se definir como modernas ou tradicionais, como se isso pudesse aliviar a angústia em face do mundo em rápida transformação.

Fazendo uma reflexão semelhante à de Roudinesco (2003), Figueira (1987) procura analisar os dois ideais de família que estavam em jogo nesse processo de modernização. $\mathrm{O}$ primeiro ideal diz respeito à família hierárquica. Nesse modelo, cada membro da família se vê como "intrinsecamente diferente do outro". A começar pelo homem e mulher: estes desempenham papéis muito distintos, como por exemplo, o sustento da família. Geralmente, o pai trabalha fora e a mãe se ocupa da educação dos filhos. Por esse motivo, o pai se coloca numa posição superior à mulher, e assim ele é visto por toda a família. Em relação aos filhos, o mesmo se coloca: os pais são aqueles que sabem mais, são mais experientes e por isso exercem a autoridade, decidindo e determinando grande parte da vida dos filhos, às vezes até mesmo sua profissão.

Para Figueira (1987, p. 16), a identidade na família hierárquica é “posicional”. Todos os membros se definem a partir de sua posição, sexo e idade. No que tange ao código moral, este parece rígido; não há muita dúvida em relação ao que é certo e ao que é errado e a família dispõe de certos dispositivos (dentro e fora dos próprios indivíduos) para tentar controlar as diversas formas de desvio de comportamento, pensamento e desejo dentro da sua estrutura.

Vale marcar que o autor fala de um ideal de família - as famílias “reais” buscavam espelhar-se nele, mas havia uma margem de manobra, a possibilidade de seguir alguns pressupostos e até mesmo esconder da sociedade o que fugia às regras. Nelson Rodrigues mostrou com maestria os sacrifícios impostos aos indivíduos e até mesmo o cinismo desses arranjos familiares.

Além da modernização em curso, houve também um contexto político e social que favoreceu o questionamento do ideal hierárquico. Esse processo veio ainda acompanhado pelos fenômenos da nuclearização, isolamento e privatização da família, levando à perda progressiva dos laços com a comunidade e a família extensa. A esse contexto se juntou a difusão da ideologia do igualitarismo. Em consonância com o movimento de personalização, descrita por Lipovetsky (2006), este iria transformar, pelo menos no nível visível, as relações familiares. 
A ideologia igualitária abriu a possibilidade de resolução de alguns conflitos próprios do modelo hierárquico. No entanto, deu margem para uma configuração familiar relativamente instável, posto que estabeleceu, nas palavras de Figueira (1987, p. 16), a "igualdade formal entre pessoas diferentes que se relacionam tendo a igualdade como ideal regulador”.

No segundo ideal, o da família igualitária, a identidade é, então, “idiossincrática”, cada membro se percebe diferente do outro, mas igual como indivíduo. Nesse contexto, as diferenças pessoais subordinam as diferenças de posição, sexo e idade. Os marcadores de diferença, antes vistos como fundamentais, tomam a conotação de "gosto pessoal”.

O código moral é tomado de grande elasticidade: o certo e errado saem de uma lógica dualista e maniqueísta e a noção de desvio à norma passa a ser relativa. As formas de controle do comportamento de cada membro são relegadas à esfera individual. Como se vê, trata-se da disseminação do processo de "personalização", postulando o livre desenvolvimento da personalidade do sujeito, a liberdade de expressão e o respeito às singularidades. O único limite claro é o do respeito à individualidade do outro.

Novamente é importante marcar que se tratava de um ideal, de uma nova possibilidade de regularizar as relações dentro da família. Isso não quer dizer que famílias já arraigadas ao seu modo de ser mudaram instantaneamente. Apesar do desejo de fugir de um padrão opressivo, a maioria das famílias viveu um longo processo de transformação, resultando em intensos conflitos individuais e conjugais, além do sentimento de desorientação na educação dos filhos.

A dificuldade de conviver com a aparente modernização social, de ter de adaptar-se a uma sociedade competitiva e a uma nova constituição familiar resultou em um sentimento de desorientação. Isso somado a uma moral mais tolerante, assim como à perda de instituições que antes orientavam essas famílias, levou ao que Figueira (1992, p. 84) chama de “desmapeamento”. Esse fenômeno decorre de uma modernização excessivamente rápida, não dando lugar a uma verdadeira reestruturação social e individual com novas bases.

Ana Maria Nicolaci-da-Costa (1985) nos ajuda a compreender o conceito de desmapeamento. Ele diz respeito à convivência de dois níveis diferentes de valores ou “mapas” que foram internalizados em momentos diferenciados da formação do indivíduo, o que significa que dois sistemas de valores contraditórios coexistem no seio do indivíduo, em planos diferentes e de forma dissociada, isto é, sem ter havido "nem a erradicação de 
conjuntos de valores, nem sua integração [...]”, nas palavras de Nicolaci-da-Costa (1985, p. 159). Em suma, nas camadas latentes permanece uma referência mais arcaica, visto que está aparentemente ausente na sociedade; contudo, ainda está vivamente presente, ainda que de forma fragmentária, no sujeito.

O fenômeno do desmapeamento adveio da modernização acelerada, isto é, da adesão imediata a novos valores, mas inconscientemente, permanecia uma formação conservadora. $\mathrm{O}$ sentimento de desorientação, decorrente do desmapeamento, resultou em um mal-estar muito grande nas famílias.

Figueira (1987, p. 24) observa dois movimentos frente ao sentimento de desorientação das famílias. O primeiro foi de procura por uma ajuda externa, por meio de um processo terapêutico. A psicanálise, disciplina que poderia se configurar como uma maneira de solucionar esse conflito, ganhava um espaço maior na cultura urbana da década de 1970, com o movimento da contracultura e com os movimentos políticos de contestação à ditadura. Houve também a diáspora de psicanalistas argentinos, fugidos da ditadura Argentina, e constituiu-se, no Brasil, uma cultura psicanalítica que procurava compreender o novo malestar social.

Assim, para Figueira (1992, p. 84), desse conflito vivido pela classe média surgiu a demanda por um sistema simbólico organizador, e a psicanálise foi chamada a assumir um papel nômico, de propor novas referências para orientar os sujeitos.

Figueira (1992) aponta as aparentes mudanças nos comportamentos nas classes médias brasileiras, entretanto estas sempre se mostram superficiais, revelando uma base tradicional. Dentre as mudanças, está a nova condição da mulher, que participa ativamente do mercado de trabalho, no entanto continua inferior ao homem no que diz respeito à remuneração. As relações afetivas ficaram menos formalizadas, como o uso do "ficar", modalidade de relacionamento instantânea, que não implica compromissos. Contudo, se a aproximação entre os sexos parece ter sido facilitada, a possibilidade de constituição de um relacionamento estável é cada vez mais afastada.

Há no Brasil o (aparente) desejo de ser moderno, de romper barreiras tradicionais em todas as esferas, contudo a postura hedonista de busca de liberdade e de novas experiências, apontada por Lipovetsky (2006), vem acompanhada de angústia e sentimento de desorientação. 
Nas palavras de Figueira (1992, p. 89): “O mergulho no novo foi muito rápido e se articulou a velhas formas que não foram abandonadas”. Daí a procura pela psicanálise, principalmente na década de 1970 , cedendo lugar depois aos fármacos. ${ }^{135}$ No entanto, o máximo que a psicanálise pode propiciar é a tomada de consciência da contradição entre o visível e o invisível, isto é, entre o moderno e o arcaico que reside em cada um, e aí cabe ao sujeito se posicionar, verificar qual é a verdade do seu desejo.

Figueira (1987) aponta uma segunda maneira de lidar com o desmapeamento, além do processo psicoterapêutico: a falsa modernização ou “modernização reativa”, a qual representa uma forma de resolver o impasse e o conflito gerados pela modernização acelerada. Pode significar o primeiro passo no sentido de conquistar, efetivamente, uma modernização dos valores, mas também pode representar uma fuga para frente, como afirma Rouanet (2000, p. 269), sem jamais chegar a isso.

Para explicar no que consiste a modernização reativa, Figueira (1987, p. 25) parte de duas maneiras de se relacionar com as regras. Na primeira, toma como modelo a relação hierárquica. Neste paradigma, a relação entre o sujeito e a regra é heterônoma, o sujeito se submete a uma norma estabelecida desde o exterior e o mecanismo de decisão é simplesmente obedecer ou não. Na segunda situação, corresponderia a uma relação igualitária. A forma de o sujeito lidar com a norma é autônoma. Neste caso, o mecanismo da decisão consiste em o sujeito discernir entre as diversas possibilidades e tomar sua decisão.

Para Figueira (1987, p. 27), a modernização reativa consiste no conteúdo da regra ser moderno, mas o mecanismo de decisão permanecer arcaico. O sujeito não tem o direito de opção, isto já vem determinado desde o exterior. Há uma modernização do conteúdo, ao passo que o código moral se mantém maniqueísta. O sujeito permanece numa relação de heteronomia. Um exemplo dessa modernização é que passamos do tabu da virgindade ao tabu da não-virgindade; não é facultado à (ao) jovem decidir quando e como vai perder a virgindade. A regra agora é: não pode mais permanecer virgem a partir da adolescência.

Na falsa modernização, como diz Figueira:

\footnotetext{
${ }^{135}$ Birman (2006, p. 190) comenta que na modernidade o mal-estar se configurava como sofrimento, e este levava o sujeito a fazer um apelo ao outro, no sentido de procurar uma ajuda (dentre elas, a análise). Já na pósmodernidade, segundo o autor, o mal-estar se configura como dor, e essa consiste em uma experiência em que o sujeito se fecha sobre si mesmo, não existindo um lugar para o outro em seu mal-estar. Daí a procura pelo medicamento, que, na crença do sujeito, cura o mal-estar "orgânico", e não subjetivo; além disso, dispensa o processo analítico.
} 
O conteúdo moderno opera, então, como um bloqueador do conteúdo arcaico que permanece, porém, inconscientemente ativo, sempre pronto para se manifestar, sempre exigindo que a reatividade aumente para garantir sua supressão. (1987, p. 27)

\section{9 $O$ arcaico e o moderno na cultura brasileira}

Esse desejo de modernização vem de longe em nossa história. A fim de compreender o impacto da modernização com uma cultura de raízes coloniais, vamos recorrer a alguns pensadores sobre a formação política e social brasileira.

Para Paulo Eduardo Arantes (1997, p.13), o imaginário de uma constituição da nacionalidade brasileira sempre alinhou a evolução nacional à modernização. Em vez de resolver as pendências herdadas do complexo colonial, a modernização agravou ainda mais a situação de dependência, comprometendo o almejado desenvolvimento econômico e a formação de uma nação justa. Ficamos, assim, condenados a ter uma face moderna sobre uma base profundamente arcaica.

A modernização a qualquer preço acabou marcando a nossa relação com a lei. Nas palavras de Antonio Candido (1978):

Uma sociedade jovem, que procura disciplinar a irregularidade de sua seiva para se equiparar às velhas sociedades que lhe servem de modelo, desenvolve normalmente certos mecanismos ideais de contensão, que aparecem em todos os setores.

No Brasil, no que diz respeito às leis, estas foram rigorosamente formuladas, criando uma ilusão de ordem e justiça, porém tudo se trata de uma mera aparência, pois essas leis foram elaboradas tendo em vista os interesses particulares. Daí a gênese de nossos padrões tão irregulares de sociabilidade e vida econômica.

Se considerarmos a formação política brasileira, observamos que se trata de uma sociedade que se criou sem um Estado, o que temos aqui é algo bem diferente do que se considera o Estado liberal capitalista moderno. Como comenta Renato Janine Ribeiro (2000), funcionamos como uma república, mas com o princípio da monarquia, que defende seus interesses privados.

Tomando novamente Antonio Candido (1978), este mostra que todas as sociedades modernas lutaram pela sua institucionalização, iniciando pelo estabelecimento de um código 
ético. Nele, fica estabelecido o valor dos pares antitéticos, isto é, o lícito e o ilícito, o verdadeiro e o falso, entre outros. Quanto mais rígida a sociedade, mais claro é o código e menor é a margem de negociação - ou o cidadão está dentro dos limites da lei, ou está fora.

Quando o autor compara a formação política dos Estados Unidos à do Brasil, notamos que, no primeiro caso, houve uma normatização social, uma marca constritora da lei, acarretando o temor da punição e o sentimento de culpa por parte do transgressor. Já no nosso país, percebemos que não foi estabelecida uma norma geral que perpassa a todos. Não houve a interiorização de um código normativo.

A lei no Brasil, paradoxalmente, não é dotada da impessoalidade, pois não vale igualmente para todos. Ao contrário, foi configurada de maneira estratégica, sendo elaborada de acordo com os interesses da elite. Exemplo disso é que a constituição do Império, outorgada em 1824, era omissa em relação à escravidão. ${ }^{136}$

\section{Como diz Souza:}

A ausência efetiva da lei, no seu sentido amplo, significava um poder sem limites, dotava o poder em todas as relações sociais, aos olhos de dominantes e dominados, de um igual poder de fascínio. A inexistência da lei numa relação social básica, espraiava o que [Joaquim] Nabuco chamava de poder pessoal para todas as outras relações da sociedade. (1996, p. 364)

Dessa forma, a relação do brasileiro com a lei sempre foi muito ambivalente. Para a elite, a lei defendia os seus direitos, já as classes populares não se viam representadas por ela. A falta de uma lei justa, que contemplasse a todos, abriu espaço para a emergência da instituição do favor, correlato aos privilégios da elite, o qual perdura até hoje.

Assim, a dialética da malandragem, proposta por Candido (1978), fala do estatuto singular da lei na cultura brasileira, da oscilação entre a ordem e a desordem, entre o que é regido pela lei e o que é regido pelo capricho, de “uma realidade válida para lá, mas também para cá da norma e da lei.”

O desmapeamento de que fala Figueira (1987) tem relação com o fenômeno da modernização reativa, sobretudo pelo aspecto invisível dos fundamentos da cultura brasileira, o qual tem suas ressonâncias no funcionamento da família da elite e da classe média. O caráter tardio da organização da sociedade resultou em uma ausência de espírito público,

\footnotetext{
${ }^{136}$ A Constituição de 1824 mantinha a escravidão utilizando certos subterfúgios, como o termo "homens livres", isto é, dando a entender que poderia haver homens "não-livres".
} 
geralmente reconhecido como espaço conquistado pelas lutas sociais e lugar por excelência da lei. No entanto, as lutas sociais foram apagadas da memória brasileira.

A forma como a sociabilidade foi sendo construída ao longo da nossa história levou a elite e a classe média ao isolamento em relação ao espaço público e a restrição à vida privada. Como afirma Kehl (2003), esse padrão de seleção e exclusão da elite brasileira foi imitado pelas classes mais baixas, na procura de marcar as diferenças em relação àqueles que se encontram num patamar social mais baixo.

A relação das elites com as instituições públicas sempre foi uma relação de conflito ou de menosprezo. Sérgio Buarque de Holanda (2006, p. 159) captou de maneira sensível a resistência das famílias patriarcais a se curvarem ao Estado, representado pelas instituições sociais:

Ao contrário, é possível acompanhar, ao longo de nossa história, o predomínio constante das vontades particulares que encontram seu ambiente próprio em círculos fechados e pouco acessíveis a uma ordenação impessoal. Dentre esses círculos, foi, sem dúvida, o da família aquele que se exprimiu com mais força e desenvoltura em nossa sociedade.

Enfim, o historiador revela como a lógica do familismo se sobrepõe à ordem impessoal; as “virtudes familiares”, às virtudes públicas.

Apoiando-se no mesmo autor, Souza (2006) aponta que os valores da organização da sociedade brasileira estiveram muito mais pautados na família do que nas instituições públicas. Referindo-se ao "homem cordial”, afirma que em nossa cultura os afetos prevalecem sobre a lei. No entanto, a característica mais aparente dessa cordialidade, que consiste em guiar-se pelo familiar e pela simpatia, é apenas uma face da cultura brasileira; a outra face é a violência.

Nesse sentido, Figueira (1992, p. 91) comenta que tudo que está fora do mundo familiar é associado ao estranho, ao ameaçador, pois não se estruturou uma verdadeira experiência de vida pública. De forma geral, nas sociedades complexas, o Estado é presente, por meio da lei e das instituições sociais. Assim foi na França; a escola pública, a dita escola republicana, era aquela que iria formar o cidadão, independente da classe social. Nesses países, a lei é vista como algo neutro e que regula a vida pública.

Já no Brasil, o Estado foi omisso e não estruturou o espaço público. Exemplo disso foi a institucionalização tardia do ensino público. A lei foi identificada como algo estranho; 
ela não foi usada para regular a vida pública, mas sim para assegurar privilégios. Sem a impessoalidade da lei, as relações ficaram reguladas pela cordialidade e pela violência.

\subsection{A família sitiada}

Restritas à vida privada, freqüentando escolas particulares, vivendo em bairros protegidos, a elite e a classe média raras vezes tiveram de se submeter a uma regra abstrata, impessoal. A lógica do familismo sempre foi predominante, tornando difícil a constituição da noção de alteridade. Nesse contexto, os modelos identificatórios ficam, então, restritos ao mundo familiar. Para Figueira (1992), a dialética da malandragem aliada à lógica da inclusão familiar regem a organização familiar no Brasil. ${ }^{137}$

Essa herança cultural acaba por afetar a própria subjetividade, pois podemos depreender que a lei no Brasil parece não ter um estatuto simbólico, e sim, imaginário. ${ }^{138}$ Para Dufour (2005), a marca do sujeito moderno é a reflexão, o diálogo com si mesmo e com a norma. Neste diálogo, sua visão oscila entre o que é a norma e o que é seu desejo. Se a lei que está estabelecida no nosso país não contempla a todos, então esse diálogo não é possível.

Podemos concluir que, no Brasil, a lei não iguala a todos, mas discrimina. Observamos essa marca da nossa cultura nas condutas sociais: as famílias da classe média lidam com a lei de forma pessoal, respeitam-na quando é de sua conveniência.

Diante de uma lei que vale para poucos, cria-se a “cultura narcísica da violência”, de acordo com Costa (1991, p. 134). Neste contexto, a família tem se guiado pelo que o autor denomina razão cínica: tendo de sobreviver socialmente nesse cenário, a família de classe média mantém uma postura de "hibernação social”, na qual procura manter o exercício da cidadania reduzido ao mínimo.

Vale destacar que Costa (1991) se apóia na obra de Christopher Lasch, O Mínimo Eu. Sobrevivência psíquica em tempos difíceis (1984). O próprio título revela que não se trata de uma postura "egoísta”, mas do isolamento por temor ao mundo externo. No mesmo sentido, a família preocupa-se com sua segurança, seu bem-estar e sua reprodução. Lasch (1984) fala da "mentalidade sitiada", o que acreditamos ser bem ilustrativo em relação a esse

\footnotetext{
${ }^{137}$ Como comentamos anteriormente, esse padrão de sociabilidade da elite acaba se disseminando para as outras classes sociais.

${ }^{138}$ A lei acaba sendo fruto do desejo do sujeito; assim é para a elite.
} 
caso. Ao sitiar-se, primeiro a família de classe média deixa de trocar, tornando-se autoreferente, e, em segundo lugar, não estabelece laços associativos, que é uma forma de exercer a cidadania. Ao contrário, os valores relativos à civilidade são lembrados apenas em episódios de violência urbana, quando o próprio núcleo familiar se vê ameaçado.

Apesar da desejada privacidade da família, esta teve de se abrir em virtude da pregnância da mídia e da cultura juvenil, nas últimas décadas. Os jovens “forçaram” tal abertura, uma vez que a televisão, onipresente na casa e na vida dos adolescentes, impele-os para o mundo externo, assim como a internet, que também leva a essa expansão para fora do meio familiar. De acordo com Kehl (2003), o papel dessa na abertura do núcleo familiar foi decisivo.

Se houve uma “desprivatização” aparente, não podemos nos esquecer do que aponta Figueira (1992), sobre a modernização reativa, em que valores contraditórios ainda coabitam no imaginário das famílias de classe média. De um lado, parecem flexíveis, tendo em vista a abertura para o exterior. De outro lado, os pais continuam vendo o espaço público como algo perigoso, ainda mais com o acesso facilitado às drogas, o risco da contaminação da AIDS e todos os fantasmas que assolam os pais dos jovens na atualidade. Em sua essência, as famílias continuam refratárias à lei, tentam defender seus interesses de qualquer forma e entram em conflito com as instituições quando estas não correspondem aos seus desejos, como no caso das escolas.

Restritas ao trabalho, à televisão e ao consumo, as famílias parecem cada vez mais empobrecidas culturalmente, não se abrindo verdadeiramente para o exterior e para a vida pública. O que vem de fora sempre parece ameaçador. Nesse caso, os filhos, quando estão fora de casa, são monitorados por celulares e por toda sorte de controle. Desde pequenas, as crianças e adolescentes são ensinados a desconfiarem de estranhos. A relação que estabelecem com a cidade e o espaço público é “cinética”, os jovens passam pelos lugares, mas não ficam neles, não interagem, não criam raízes. Não são criados para a vida pública.

No que diz respeito à relação com a lei, a família brasileira ainda utiliza a sua lógica pessoal para tentar burlar a norma, quando isso lhe parece interessante. Os adultos dão exemplos diários de descumprimento da lei e da tentativa de escapar das punições. Assim, os filhos aprendem com os pais que não é necessário seguir a lei, e esperto é aquele que a transgride, mas nunca é punido. Isso nos remete a Candido (1978), que, ao se referir à relação do brasileiro com a lei, diz: “[...] a repressão moral só pode existir, como foi dito, fora das consciências”. 
A prevalência dos afetos sobre a impessoalidade da lei é uma marca da nossa cultura, no entanto há elementos externos que foram se combinando com essa organização familiar, resultando em algo bem singular, sobretudo em relação ao exercício da autoridade. Roudinesco (2003, p. 88) propõe um atributo para marcar uma tendência geral do núcleo familiar dos nossos tempos. Denomina família afetiva contemporânea, termo que expressa bem a linha-mestra que sustenta a nova ordem familiar. Trata-se de um elemento já posto com o advento da família edipiana, isto é, a revolução da afetividade, que coloca como princípio do casamento a associação entre o sentimento amoroso e a realização sexual dos cônjuges.

François de Singly (2000) comenta que, até por volta da década de 1960, a família era regida por uma "lógica de grupo”, centrada no amor e na afeição. A partir das mudanças sociais, a antiga lógica cede lugar à "lógica da individualização”, ao bem-estar dos membros que a compõem. O importante não é mais o grupo reunido, mas ser feliz. Daí o aumento do número de divórcios e do surgimento de novas formas de famílias.

No novo modelo familiar, segundo Singly (2000), cada membro do casal almeja ser "livre junto". O autor denomina esse modelo “família relacional e individualista”. A necessidade de estar em harmonia, de amar e de ser amado o tempo todo é a regra. Uma crise conjugal não é mais vista como algo processual, algo que faz parte das relações humanas. Cada crise torna-se uma ameaça, fragilizando os vínculos do casal.

Outros elementos intervêm nessa demanda de afeto. A vida profissional tornou-se bastante tensa, em decorrência da competição acirrada no mercado de trabalho. Nesse sentido, o reconhecimento e a harmonia no lar tornam-se fundamentais para os pais, daí a necessidade de ter na família um refúgio, sobretudo na relação com os filhos. Os pais querem ter com sua prole uma relação tranqüila, e os conflitos são evitados. Logo, quando se tem de estabelecer normas e desagradar às crianças e aos adolescentes, freqüentemente os pais fogem dessa tarefa, pois não querem ser considerados “autoritários”. Acreditam que, ao fazer isso, correm o risco de perder o amor dos filhos. A conseqüência é que os filhos não aprendem as normas, não se tornam capazes de sustentar a renúncia pulsional e por isso ficam aprisionados aos seus desejos.

Se o prazer está colocado como princípio na relação conjugal, o mesmo está posto na relação entre pais e filhos. A ética hedonista e permissiva faz com que os pais deixem para um nível secundário a socialização das crianças, em prol dos momentos de prazer na vida privada. Para Figueira (1992, p. 89), as crianças são criadas com uma noção muito vaga do social, das regras e do dever. Como as instituições sociais nas últimas décadas não são tão mais presentes 
na vida das crianças, elas ficam despreparadas para a vida pública. Como afirma o autor, o controle do comportamento das crianças tornou-se mais oportunista do que ético, tendo em vista o viés instrumental com que a classe média tem marcado a educação das novas gerações.

Isso nos remete ao que Figueira (1987) apontou em relação à modernização da família: a adesão ao ideal igualitário teve conseqüências na relação entre pais e filhos. Antes as relações eram pautadas pelas diferenças: de posição, de sexo e de idade; com o novo ideal, elas passaram a serem pautadas pela igualdade.

Isso levou a um enfraquecimento dos limites entre categorias que são intrinsecamente diferentes. Diluíram-se diferenças ao se estabelecer a nova configuração dos membros familiares num grupo comum: indivíduos. Pais e filhos, que guardam diferenças essenciais, foram igualados. Com isso, foram eliminadas as barreiras geracionais, o que deu margem a grandes equívocos e, em última análise, ao demissionamento dos pais na educação dos filhos, sobretudo em relação aos adolescentes.

Como vimos, a família contemporânea se configura como um núcleo sitiado, lutando para fazer valer a lógica da individualização, da felicidade de cada membro. Os pais são pressionados pelo mercado, pela necessidade de um bom desempenho no trabalho, pelo desejo de sucesso pessoal, e a convivência com os filhos fica reduzida a uma parcela diminuta da rotina. Nos poucos momentos de convivência familiar, os pais acabam optando pelo prazer e pela gratificação mútua. Incertos quanto ao valor da norma no futuro, preferem a permissividade no presente.

Apesar de aparentemente abertas, essas famílias, em suas camadas latentes, permanecem isoladas, avessas à troca, como se o que viesse de fora fosse ameaçador ao seu modus vivendi. Perdem, com isso, o espelho do outro, a possibilidade de questionar suas referências, bem como de delimitar seus lugares simbólicos. A ausência de normas e o aumento das exigências narcísicas levam ao emaranhado das gerações, como afirma Jeammet e Corcos (2005).

A delimitação dos lugares simbólicos tem uma dupla dimensão: de um lado, ela limita e de outro lado, protege e estrutura. Quando há uma clareza dos lugares simbólicos, a família pode tornar-se um lugar de negociação entre a autoridade e a liberdade, entre o vínculo e a autonomia, entre a satisfação pulsional e o adiamento das gratificações.

No entanto, essa clareza dos lugares simbólicos parece ser cada vez mais difícil. A relação entre pais e filhos, que, por princípio, deveria ser assimétrica e mediada pela 
autoridade, tornou-se uma relação horizontal, mediada pelo prazer — quase uma amizade. Não parece haver uma clareza dos limites, dos direitos e deveres recíprocos.

Como se sabe, é a cultura que sustenta os lugares simbólicos, e como esta está permeada pelo processo de personalização, do culto exacerbado à individualidade e autonomia, parece "natural” abrir mão da autoridade e do lugar de adulto em relação às novas gerações.

Se não há mais um respaldo social no que diz respeito às normas coercitivas, educar as novas gerações tornou-se uma tarefa árdua, e cada adulto tem de fazer isso por sua própria conta e risco, como assinala Kehl (2003). Um fundamento simbólico que parece permanecer ativo é o da responsabilidade do adulto pela proteção e cuidado dos mais jovens. Talvez a responsabilidade pelas gerações vindouras represente a única certeza subjetiva com que os adultos podem contar. Ocupar o lugar simbólico consiste, então, em assumir o risco pelas novas gerações.

Sabemos que esse risco implica ônus, renúncia, e muitos não parecem dispostos a fazer isso. Observamos em muitas famílias na atualidade a recusa da realidade, na acepção psicanalítica, a recusa de uma diferença básica: a do lugar geracional. Isso implica a não aceitação do fim da própria juventude. Pais se relacionam com os filhos como iguais, como se estes fossem capazes de compreender questões complexas, de se auto-regular, de fazer antecipações, que eles absolutamente não estão em condições de realizar. Em outras palavras, os pais abandonam seus filhos.

A contrapartida são as crescentes passagens ao ato dos jovens. Trata-se da impossibilidade de expressar e elaborar o conflito entre a aspiração à autonomia do adolescente e as tendências que mantêm a situação de dependência em relação aos pais.

Nesse sentido, a conduta da recusa escolar está na ordem da atuação. Trata-se de algo diferente da passagem ao ato. Como já foi afirmado anteriormente, a passagem ao ato representa uma pura descarga de excitabilidade sem qualquer simbolização. Já a atuação, de acordo com Joel Birman (2006, p. 216), consiste em uma exteriorização de algo inscrito como representação no psiquismo; corresponde a “uma dramatização em ato de uma cena psíquica”.

A meu ver, a conduta de recusa escolar, manifesta por Fábio e Otto, corresponde à atuação de um conflito que não lhes diz respeito, mas, sim, aos pais. No caso desses jovens, a recusa escolar parece ser a exteriorização dos impasses advindos da recusa da realidade dos pais — a recusa do luto da juventude — mas também a exteriorização dos conflitos 
decorrentes da modernização reativa desses pais, pois ainda permanece presente nesses indivíduos (em suas camadas invisíveis) a necessidade de fazer valer sua vontade, de não se subordinar às normas, enfim, de resistir à institucionalização.

Em suma, por trás da postura liberal e hedonista desses pais, se esconde um desejo arcaico (e autoritário). 


\section{Considerações finais}

Retomando nossa pesquisa, partimos da narrativa de casos com adolescentes no contexto da psicopedagogia clínica. Da singularidade, passamos, então, para a articulação com outros referenciais a fim de alcançar uma compreensão abrangente desses casos de recusa escolar entre os adolescentes.

A metodologia de investigação do estudo de caso, como entende Robert Yin (2001), consiste em partir de um contexto particular cujo foco seja dirigido para um fenômeno contemporâneo. A meu ver, dentre as evidências que foram se delineando nas narrativas dos casos, a questão da negação da diferença geracional foi o elemento que mais se distinguiu, constituindo, assim, a questão a ser estudada.

A preocupação desta pesquisa foi de estabelecer um confronto entre o particular e o geral, sem, contudo, reduzir um ao outro. A intenção era atritar ambos e desse atrito provocar alguns aclaramentos, que possibilitassem a atribuição de novos sentidos.

Desse confronto, o primeiro ponto que se evidenciou foi o de que certas dificuldades de aprendizagem na adolescência fogem daquilo que Paín (1985) denomina problema de aprendizagem como sintoma e merecem uma compreensão mais ampla. Recorrer somente à Psicopedagogia não foi suficiente para entender problemas escolares na adolescência que ultrapassam uma dificuldade cognitiva e que se manifestam, sobretudo, pela retirada do investimento do jovem tanto do processo de aprendizagem, como da aquisição da autonomia.

Foi necessário buscar subsídios na psicanálise para, num primeiro momento, compreender a adolescência como conflito entre o desejo de alcançar uma autonomia e as tendências contrárias, as quais mantêm o vínculo de dependência do jovem com os pais. Jeammet e Corcos (2005) apontam para o fato de a adolescência consistir em um trabalho psíquico do sujeito, de articulação entre o mundo interno e o mundo externo. Num segundo momento, o foco se voltou para o ambiente familiar, que desempenha um papel fundamental nessa problemática e funciona como suporte para que o adolescente consiga realizar as tarefas desenvolvimentistas: a integração do corpo púbere e a progressiva conquista de autonomia em relação aos pais.

A riqueza da abordagem de Jeammet e Corcos revela-se justamente pelo fato de estes autores fazerem uso da psicanálise extensa, procurando elucidar alguns elementos que dizem 
respeito ao campo social, e que têm ressonâncias para o que eles denominam a emergência das patologias do agir e das condutas de recusa na adolescência. Dentre esses elementos, vale assinalar aquilo que eles denominam a pseudomutualidade familiar e o emaranhado das gerações, os quais parecem ser produto da diluição das normas coercitivas em benefício das exigências narcísicas.

Nos dois casos estudados tivemos a oportunidade de ver famílias em que adultos e adolescentes se confundem, vivem como se fossem iguais, sem a assimetria necessária nas posições e relações. Os pais deixam de estabelecer limites para não entrar em conflito com os filhos. No entanto, o conflito se mostra inevitável, em face da ausência de controle dos adolescentes, que ficam à mercê dos próprios desejos.

Os pais desejam dar liberdade aos filhos e acreditam que devem deixá-los à própria sorte. Ao contrário, a liberdade se constitui sobre a base de segurança e confiança. É a partir do modelo dos pais, que, agindo de forma segura e confiante, propiciam a interiorização destes sentimentos pelos jovens. Sem essa vivência, os adolescentes não adquirem segurança e confiança em si próprios. Permanecem dependentes dos adultos e desprovidos de recursos para abrir-se para o mundo mais amplo.

A relação de dependência foi se constituindo como mais uma daquelas relações entre o singular e a totalidade. Ela é chave para a compreensão da recusa escolar. Jeammet (2002) observa que alguns jovens apresentam essa conduta em momentos de transição de um contexto mais protegido para outro, em que se exige maior autonomia. Diante da incapacidade de responder a essa demanda, o adolescente acaba por manifestar um comportamento de autosabotagem - priva-se de fazer aquilo de que sempre gostara e em que se saíra bem até então. No caso de Otto, era clara a sua ambição de ser um intelectual, como os demais membros da família, no entanto passou a fracassar na escola.

A recusa representa uma forma de expressar um desejo autônomo, de marcar a própria identidade, pois o adolescente se vê tomado pela ambivalência frente aos pais: aqueles de quem ele deseja se ver livre são aqueles de quem ele mais necessita. É como se fosse uma revanche - não é mais o jovem que é dependente, ele passa a comandar a situação e tem os pais sob controle, pois estes percebem que o filho está em risco.

É nesse sentido que Jeammet relaciona a recusa escolar às patologias do agir: ambas consistem numa conduta de passividade-ativa e levam o adolescente a uma reclusão familiar. 
Nos dois casos que examinamos, a recusa escolar levou a um isolamento dos jovens. Fábio ficou restrito ao lar e Otto acabou se privando de uma nova experiência — a de morar numa nova cidade e a de ampliar seus vínculos sociais — e teve de voltar à cidade natal, junto da avó - mãe.

Dois motivos me levaram a investigar mais a fundo o conceito de recusa na psicanálise. O primeiro foi o fato de ele ter relação com a questão da castração, noção fundamental na construção freudiana, e que corresponde a um elemento emergente na dinâmica da adolescência. O segundo foi o fato de eu observar nos casos de recusa escolar não só uma dificuldade dos jovens de romper o vínculo de dependência, como certa complementaridade dos pais na manutenção de tal relação.

O estudo da recusa da realidade nas obras de Freud e em Penot (1992a) ampliou o entendimento da noção de recusa escolar, no sentido de iluminar um aspecto ainda obscuro: o determinismo transgeracional. O que o filho atuava como recusa escolar advinha de uma recusa dos pais em fazer o luto da própria juventude.

Penot alerta para a complementaridade dos pais em face do sintoma do filho. Na verdade, o sintoma do jovem revela uma situação de dependência familiar. Bebendo na mesma tradição lacaniana, Dolto (1985) vai mais longe e afirma que o filho atua um desejo reprimido dos pais.

Os pais de Fábio ainda não haviam elaborado o luto da juventude, dos ideais revolucionários ou pseudo-revolucionários que foram investidos naquele filho. Este, no seu nascimento, representou uma mudança de vida, uma aposta no futuro. O sintoma do adolescente os rejuvenescia, tornava-os pais de um filho "pequeno", que ainda necessita de extremo cuidado. No entanto, eles estavam cansados e não sustentavam mais as "travessuras" desse filho. Como Aschenbach, de Morte em Veneza, a maquiagem estava se desmanchando, revelando que a juventude há muito já se havia acabado.

A atitude competitiva de Otto em relação ao pai não parecia remontar a uma rivalidade edipiana, e, sim, a uma competição fraternal. Ela revelava a situação insólita de filho e pai colocados no mesmo patamar. Em vez de denunciar essa farsa, o pai entrava na competição para ganhar e mostrar ao Otto que ele era "burro” - como fazem dois irmãos numa situação infantil. Isso remetia a uma dificuldade do pai de Otto em relação aos próprios pais.

O desejo dos pais em permanecer jovens, os ideais que orientavam a educação dos filhos, embebidos de permissividade e de imediatismo, não eram objeto de questionamento 
por parte deles próprios. Não parecia haver uma antecipação das conseqüências desse ideário na formação dos filhos - como estudantes e como sujeitos.

Esse modelo, ou a ausência de um, parece ter ressonâncias no contexto sociocultural. Tornou-se necessário um aprofundamento sobre o cenário atual, na perspectiva de verificar as transformações nos modos de vida, na relação com a cultura, com as interdições e com as instituições sociais. A intenção era distinguir os elementos que conformam a nova ordem sociocultural, bem como suas influências sobre as relações intergeracionais.

O mergulho na obra de Lipovetsky (2006) permitiu compreender a relevância do movimento do modernismo e sua crítica aos dispositivos coercitivos e padronizadores no fim do século XIX. Esse movimento pregou a lógica personalista, de valorização do livre desenvolvimento do sujeito, da legitimação do prazer e da liberdade de expressão. Em um primeiro momento, essa lógica foi restrita à esfera cultural. Impulsionada pela revolução do consumismo, a lógica da personalização disseminou-se por toda a sociedade. Derivou no que Lipovetsky chama era pós-moderna.

Deparamos com um novo elemento, que ilumina o entendimento sobre o nosso tempo. Para Lipovetsky (2006, p. XXI), vivemos em uma segunda revolução individualista, que deriva no que ele denomina a cultura narcísica, que corresponde à mutação histórica dos objetivos e dos modos de socialização, com base na legitimação de novos dispositivos mais abertos e plurais. Essa etapa inaugura uma nova experiência do sujeito com seu corpo, com o outro, com o mundo e com o tempo.

Partindo da constatação dessas transformações da condição do sujeito e das modalidades de socialização, inúmeras foram as conseqüências para as relações intergeracionais. Dentre elas, vou destacar algumas que julgo relevantes para a discussão.

A primeira evidência é a exacerbação dos interesses individuais e o declínio dos valores superiores, da preocupação com as causas sociais. Tal preocupação é substituída pela cultura psicológica. Todos vão ocupar-se de si, da sua autenticidade, de seus sentimentos. O psicologismo, associado ao hedonismo, dá margem para a valorização de tudo que é espontâneo. Disto resulta o ideário educativo de não reprimir a criança, de incentivar a livre expressão do sujeito, de não exigir demais das crianças, entre outras crenças.

A permissividade, a falta de exigência do adulto, o relativismo em relação às interdições cobram seu preço. Redundam na baixa tolerância à frustração, na impossibilidade de renunciar às satisfações imediatas e na ausência de autocontrole das crianças e 
adolescentes. Se na infância essas manifestações são apenas desagradáveis para os adultos, na adolescência elas escapam ao seu controle.

A agressividade é um fantasma para os pais de adolescentes. Ela representa uma saída para o jovem se fazer ouvir, de fazer valer seu desejo, de ser reconhecido. Para Calligaris (2000, p. 44), quando o adolescente não consegue ser respeitado, uma alternativa é produzir medo. Fábio passou a ser agressivo com os pais, ao sentir-se “aprisionado” no núcleo familiar. Independentemente da justeza ou não de suas motivações, a agressividade denota a ausência de recursos do jovem para representar, expressar um mal-estar e para elaborar simbolicamente aquilo que a originou.

Outro fantasma para os pais de adolescentes é a droga. O pai de Otto ficou ambivalente ao tomar conhecimento de que o filho fumava maconha. De um lado, via nessa droga uma fuga da realidade, mas, de outro, a via como instrumento de liberação, tal como foi para os jovens da contracultura. Por isso não foi tão firme, chegou a ser até mesmo tolerante e o jovem permaneceu livre, sem nenhuma forma de controle. Ao contrário, o pai foi se ausentando gradativamente da vida de Otto. Sua intenção era até afastar-se ainda mais — iria trabalhar três vezes por semana em outra cidade no semestre seguinte.

A droga já não se relaciona mais a uma espécie de contracultura, ao ideal de liberação e revolução, como foi no passado. Como vimos, os dispositivos sociais estão mais abertos e plurais. O ideal de libertação não se justifica aos olhos dos jovens, exatamente por não elaborarem o mal-estar que sentem diante de si mesmos e da sociedade, que hoje é menos visível para eles. A droga passa a ser identificada apenas ao escapismo, à alienação, à fuga de si. Ela pode, também, representar uma ameaça ao desenvolvimento do jovem. Mais ainda no caso daqueles que são dependentes do suporte do ambiente. Como comenta Calligaris (2000, p. 47), pelo fato de proporcionar um prazer imediato, a droga rompe a cadeia do desejo, de deslizar de um objeto para o outro. O risco é de o jovem se abandonar nesse prazer e renunciar aos demais. Mais ainda quando a realidade oferece desafios difíceis de superar.

Uma conseqüência da cultura narcísica, que afeta sobremaneira as relações intergeracionais e que leva mesmo à quebra das barreiras entre as gerações, é a idealização da juventude. Em consonância com o processo de personalização, a juventude representa o sonho dessa cultura, o sonho de liberdade.

O ideal moderno representado pela criança e seu potencial a ser realizado no futuro cedeu lugar a um novo ideal. A modernidade representou uma ruptura com o passado, 
levando a uma nova ordenação temporal. A referência, antes advinda do passado, dirigiu-se para o futuro. O desejo narcísico de realização de tudo aquilo que os pais não realizaram recai sobre a criança.

A mutação histórica que se deu com a chamada cultura narcísica deu lugar ao imediatismo, à fixação no presente. Não se aposta mais no futuro. Mais vale o aqui e agora. Sendo assim, o ideal se volta para aquele que pode ter o prazer imediato - o adolescente. Ele tem corpo e mente amadurecidos o suficiente para ter prazer sexual, se divertir, viver aventuras (não ter responsabilidades, usar drogas, viajar pelo mundo, etc.).

Nas palavras de Calligaris:

A adolescência se torna assim um ideal dos adultos. [...] Eles encontram nos adolescentes idealizados um prazer menos utópico e mais narcisista. Os adolescentes oferecem uma imagem plausível, praticável. (2000, p. 70)

A idealização da juventude ajuda a compreender por que os pais não são proativos diante de um problema do filho aparentemente grave: a iminência de uma expulsão da escola, o envolvimento com drogas, etc. Há um lado do adulto que tem prazer com isso, que gostaria de "não estar nem aí” para o diretor da escola; que adoraria ficar se drogando entre os amigos, em vez de estudar. Os pais se realizam por meio dos filhos, ou, ao contrário: os filhos realizam o desejo dos pais.

Outro elemento a ressaltar da cultura narcísica é certa culpabilidade dos pais em relação aos filhos e a compensação dessa culpa na forma de liberalidade e oferta de objetos de consumo. Diante do desemprego estrutural, da excessiva competição no mercado de trabalho, os pais se penalizam pela vida dura que os jovens provavelmente terão quando chegarem ao mundo adulto. Procuram compensar isso com objetos de consumo e mantendo os filhos na dita moratória, que implica uma prerrogativa para a diversão, o prazer e a ausência de responsabilidades.

O fato de pais de famílias menos abastadas não poderem propiciar tudo que desejam para seus filhos, nas palavras de Kehl (2007), “não significa que eles não alimentem a mesma perspectiva de felicidade para eles, e não se sintam em dívida por não poder obtê-la para os filhos”. Assim, acabam se sacrificando para proporcionar objetos de consumo similares e sendo mais tolerantes com as faltas dos filhos.

O aprofundamento sobre a cultura narcísica possibilitou elucidar aspectos da ordem sociocultural, que acabaram por configurar as novas modalidades sociais e o "território mental 
da vida”, nas palavras de Hobsbawn (1995). Entretanto, alguns elementos próprios da estrutura familiar, como a autoridade compartilhada e suas conseqüências, bem como o estatuto da lei na realidade brasileira, mereceram um novo estudo.

A psicanálise nos mostra que o sujeito se forja no campo da intersubjetividade, necessitando da referência a outros sujeitos para se constituir. Nesse sentido, a essência do papel dos adultos na educação é propiciar modelos identificatórios aos mais novos. Esses modelos indicam a relação desses adultos consigo mesmo, com a cultura e com os semelhantes e consistem em balizas para a constituição do sujeito.

É por meio das identificações que o sujeito interioriza os modelos que a sociedade oferece e se torna um membro da comunidade. A família representa o mediador social que estabelece as marcas mais profundas no sujeito. Os primeiros adultos com os quais a criança se identifica são os pais e, em seguida, outras pessoas colocadas em posição de autoridade, como diz Freud.

Vimos com Roudinesco (2003) a transformação da família de uma estrutura hierárquica, tendo o pai como centro, para uma estrutura horizontal e fraterna, que a autora denomina a família afetiva contemporânea.

Vale discriminar dois aspectos em relação à transformação da família. O primeiro, em relação ao casamento; quanto mais este se ancora sobre o amor e a satisfação sexual, mais ele se fragiliza. O segundo aspecto diz respeito ao grupo familiar como um todo. Ao longo desse processo, houve uma humanização nas relações familiares, entretanto a autoridade tornou-se difusa e problemática, donde podemos concluir que a vida familiar tornou-se complexa e difícil.

Essa transformação, que se deve ao processo de personalização, à revolução do consumismo e à entrada da mulher no mercado de trabalho, acabou por modificar as relações sociais, como também as instituições. Essa evolução social foi acompanhada pela progressiva urbanização e mudanças nos modos de vida.

A família costumava dividir a tarefa educativa com a família extensa e com a comunidade, que representavam um continente que amparava a família, segundo Souza (2004, p. 10), pois partilhavam de uma certeza subjetiva que sustentava as normas e valores que os pais pretendiam transmitir aos filhos. Essa certeza subjetiva advinha dos significantes que criam os laços de sentidos à vida, por meio da troca de experiências, e sem os quais as relações perdem sua substância. A família extensa também representava a função de espelho, 
situando os pais em relação à educação da nova geração. Desempenhando o papel do outro, muitas vezes era chamada a cobrir as eventuais faltas no núcleo familiar, no sentido de garantir a passagem das crianças para o mundo dos adultos.

A urbanização crescente que se deu nas últimas décadas, sobretudo nas grandes metrópoles, isolou a família e os laços com a família extensa e com a comunidade foram desfeitos. O núcleo familiar perdeu, assim, seu suporte e referência.

A isso se soma a passagem da lógica hierárquica e disciplinar para a lógica flexível e permissiva, dando lugar à dissolução das normas coercitivas. As antigas referências tornam-se anacrônicas e os modelos identificatórios são colocados em xeque. Trata-se do que Lipovetsky (2006) chama dissolução das identidades e dos papéis sociais, os quais são esvaziados de seus conteúdos; cada indivíduo passa a ter espaço para a livre disposição de si, sem as referências que propiciavam aqueles modelos.

Observamos que cada vez é mais difícil aderir a uma identidade e sustentar as perdas que essa adesão implica. Procura-se aderir a vários modelos simultaneamente, mesmo quando estes parecem incompatíveis. O pai de Otto, ao convidar o filho para ir morar consigo, não sustentou esse compromisso e, no primeiro problema entre Otto e sua nova família, fez como um irmão mais velho: ofereceu seu segundo apartamento e se desincumbiu da responsabilidade pelo filho. Saiu do lugar de pai na primeira oportunidade.

Os adultos parecem desconfortáveis em relação aos modelos identificatórios e não sustentam os padrões sociais, valores, normas, formas de autocontrole e instituições diante dos filhos. São ambivalentes quanto ao que transmitem e os adolescentes acabam destituídos de referências para se constituir como sujeitos e como se portar como cidadãos. A contrapartida é a falta de limites e o desamparo que os jovens experimentam, ficando aderidos ao presente e com dificuldades de estabelecerem projetos de futuro. Sem os fundamentos da cultura, os adolescentes se voltam para o mundo juvenil, cujas referências, eles pensam, são feitas por eles e para eles, onde nenhum tributo deve ser pago aos seus antecedentes. Desconectam-se, assim, do fio discursivo, que distribui cada geração ao seu lugar.

Vale assinalar que os limites não dizem respeito apenas às interdições. Ao estabelecer limites, o adulto possibilita a discriminação dos lugares simbólicos. Se o adulto não sustenta o seu lugar simbólico, que diz respeito à sua responsabilidade pelas novas gerações, ele pode comprometer o processo identificatório do jovem. Como afirma Mezan (2002), as identificações fundamentais necessitam ser bem ancoradas e integradas. Sem os modelos 
identificatórios, o adolescente fica dependente do apoio externo, pois não constitui os limites psíquicos internos, que decorrem do complexo de Édipo. Em suma, fica desprovido de recursos internos para conquistar a autonomia.

A ausência da marcação das barreiras geracionais parece ser um dado da cultura narcísica, que, em tempos de globalização, predomina em toda a sociedade ocidental. No entanto, examinando mais atentamente as raízes da cultura brasileira, foi possível buscar novos sentidos para a compreensão da ambivalência dos adultos para transmitir normas para as novas gerações.

Encontramos em Sérvulo Figueira (1992) novas luzes para entender o desejo de ser moderno no Brasil bem como o estatuto da lei na cultura brasileira. O autor alerta para o desejo de modernização que sempre marcou a elite brasileira. Trata-se de uma herança colonial. A modernização aqui sempre se deu de forma intempestiva, sem uma real superação do estágio anterior. Como comenta Figueira, o arcaico permanece nas camadas invisíveis e, na camada superficial, se mostra o moderno. Assim foi com a sociedade e com os indivíduos.

A rápida modernização empreendida na segunda metade do século $\mathrm{XX}$, nas aparências, transformou a paisagem brasileira, e o mesmo se deu com os padrões sociais. Em consonância com o processo de personalização, as relações pareceram tornar-se mais livres e flexíveis.

No caso das classes médias e das elites brasileira, a adesão a novos valores não deu lugar a uma revisão dos valores arcaicos. Em muitos casos, houve simplesmente uma superposição de valores. Se, de forma superficial, a família hierárquica sofreu uma horizontalização, nas camadas latentes as referências continuaram as mesmas. A conseqüência foi o sentimento de desorientação, de desmapeamento - termo cunhado por Figueira - , fenômeno que deriva do estabelecimento de processos modernizadores que se sobrepõem às bases arcaicas em um curto período de tempo, sem a possibilidade de uma verdadeira reestruturação.

Diante da angústia provocada por tal mal-estar, as famílias dos grandes centros urbanos, que sofriam de forma aguda essas transformações, foram em busca de algo externo que pudesse servir como um sistema organizador de valores. Acreditaram que a psicanálise pudesse ajudá-los. Ela poderia, mas não atendendo a tal demanda. Sua ajuda consistiu em apontar a contradição. Apesar disso, essa demanda não cessou e deu lugar à constituição de 
uma cultura psicológica, que se tornou parte de vários setores e instituições presentes na vida brasileira.

Outra forma de aplacar a angústia foi por meio da modernização reativa, que implica a adesão dos valores modernos, mas com um posicionamento arcaico, baseado na heteronomia. Haveria, assim, um “assentamento” das camadas visíveis e invisíveis. O desmapeamento não causaria mais angústia, tornando-se parte da personalidade do sujeito. No entanto, em muitos momentos, poderia emergir do inconsciente o conteúdo reprimido - o machismo, os preconceitos, etc.

Buscando nossas raízes, para compreender nossos padrões de sociabilidade, deparamos com a formação política do Brasil. As leis foram formuladas de acordo com interesses particulares, de forma a favorecer poucos. Ao contrário do que se espera, nossas leis não igualam os cidadãos, mas os discriminam.

O povo, ao não se ver representado nesse código, simplesmente não interioriza as leis. Não as legitima. Antonio Candido (1978) expressa esse estatuto singular da lei mediante o que ele chama de “dialética da malandragem”, de uma realidade que é válida tanto de um lado, como do outro lado da lei.

Pelo fato de a sociedade ter se constituído sem leis impessoais, o espaço público não foi percebido como espaço valorizado. Nas sociedades complexas, como diz Figueira (1992), o espaço público é neutro, regulado pela norma. Já no Brasil, como não há essa lei abstrata, o povo usa o espaço público se defendendo mediante o “jeitinho” e a dialética da malandragem. As famílias de elite sempre foram refratárias a esse espaço, isolando-se na vida privada. Para elas, o espaço público é considerado perigoso.

Constatamos, assim, mais uma marca da nossa cultura: o familismo. Sérgio Buarque de Holanda (2006) mostra como as famílias da elite sempre se recusaram a curvar-se às instituições, querendo manter seus valores sob a forma das "virtudes familiares". Nesse sentido, a lei da família se sobrepõe à lei impessoal.

No nosso caso, os pais de Fábio simplesmente ignoraram a lei da obrigatoriedade do ensino. Tiraram o filho da escola, quando viram que não conseguiriam garantir antecipadamente a aprovação do filho. Vemos aqui o que Antonio Candido chama de capricho, a vontade pessoal se impondo sobre uma lei abstrata. A família de Otto também se utilizava de suas influências sobre a escola. O próprio jovem me disse que não acreditava que seria reprovado quando estava na $8^{a}$ série, pois “sua família era conhecida” naquela escola. 
Apesar de se proclamarem liberais e modernos, acabavam por recorrer a tradições coronelistas.

As famílias de elite e de classe média estabelecem uma relação instrumental com a instituição escolar, e, se por acaso esta deixa de atender suas demandas, ou se impõe algo com que as famílias não estão de acordo, elas simplesmente retiram a criança da escola. No caso das classes médias, os pais escolhem escolas particulares que mais correspondem aos seus ideais e modelos.

Verificamos que o direito à educação no Brasil só recentemente foi ampliado a todos, no Ensino Fundamental e Médio. No caso do Ensino Fundamental, a democratização foi acompanhada pela perda da qualidade de ensino, cavando um fosso entre a escola pública e a privada. Isso levou a uma migração da classe média brasileira para o ensino privado. Nas sociedades complexas, onde a educação pública é disseminada e utilizada por todos, os pais têm limites ao tentar impor suas demandas particulares.

O familismo leva a uma redução no contato com modelos identificatórios diferenciados. Para Dubet (1996a), a escola passou a ser um elemento fundamental na experiência de socialização do adolescente, nas últimas décadas. A democratização escolar, que universalizou a escola para todos os jovens, produziu o alongamento da juventude e a postergação da entrada no mundo do trabalho. O autor aponta a importância que a escola assumiu para que a juventude conheça a si própria. Tornou-se tão fundamental, que o próprio fato de um adolescente não estar na escola é algo significativo na atualidade e tem conseqüências na experiência juvenil.

Como afirmam Marcelli e Braconnier, a escola estabelece um contraponto fundamental ao jovem; o espaço entre a casa e a escola se configura como

[...] uma zona de transição indispensável entre os modos de vida que nessa idade assumem toda sua importância na dinâmica entre o de dentro e o de fora, entre o passado e o futuro, entre o familiar e o estranho, entre o grupo familiar e o grupo social. (2007, p. 317)

Para Bernard Charlot (2001), a representação mais intensa que os jovens estabelecem em relação à escola está relacionada ao eixo da socialização. Para eles, a escola é um lugar de encontro, de convivência com os pares. Aliás, esse fato unifica os jovens de todas as classes sociais - eles se voltam para o mundo juvenil, para os pares e às vezes se bastam a si mesmos - as trocas intergeracionais ficam reduzidas. 
Para muitos adolescentes que vivem sob a tutela dos pais e ficam alijados do espaço público a escola é o espaço em que parecem estar livres da vigilância de familiares e onde a sociabilidade, pelo menos a seus olhos, é mais espontânea. A esfera social ocupa grande parte do investimento afetivo dos jovens. Assim era com Otto. Segundo Dubet e Martuccelli (1996), o interesse pela vida social e pela cultura juvenil "parasitam” a experiência escolar dos adolescentes.

Nesse sentido, a escola está cumprindo parte de suas funções - propiciar aos alunos a transição que hoje caracteriza a adolescência. E, apesar de a escola também ser lugar de transmissão da cultura, essa segunda função não é muito evocada pelos adolescentes, de acordo com Charlot (2001, p. 149). Esse parece ser o caso de Fábio. Tal percepção resulta de uma dificuldade de perceber, de um lado, que há uma continuidade entre a vida e a escola: aprende-se nessas duas instâncias. De outro lado, existe, talvez forçosamente, no conhecimento escolar, uma ruptura com o mundo adolescente, pois a aprendizagem escolar implica a formalização de procedimentos, a sistematização de conteúdos estranhos à vida juvenil - pressupõe a entrada numa lógica, a lógica do trabalho escolar. E, algumas vezes, o sentido desses conhecimentos é adquirido a posteriori. Quando, após aprender, o jovem chega ao sentido, percebe que muitas coisas que se aprendem na escola (ou que deveriam ser aprendidas na escola) permitem compreender melhor o mundo e a si mesmo. Trata-se da possibilidade de estabelecimento da intersignificação, segundo Charlot (2001, p. 150).

A lógica do familismo, aliada ao hedonismo da cultura narcísica, leva muitos pais a serem críticos em relação aos conteúdos escolares e até mesmo em relação às exigências dos professores. Algumas vezes podem ter razão, mas a excessiva ênfase com que se critica a escola leva psicólogos e pedagogos a não perceberem que nem sempre a razão está do lado dos pais. Na ótica dos pais de Fábio, o adolescente necessitava de uma escola especial, cujo ensino fosse mais prático e menos formal. Sem entrar no mérito se tinham razão ou não, está claro que os pais tinham um part-pris em relação a isso. Deixavam de olhar para as possibilidades do próprio Fábio, suas necessidades, escolhas e sobretudo eram insensíveis à grande solidão em que tinham feito seu filho mergulhar.

Para Sarlo, (2004, p. 104), “a cultura é sempre um corte, um desvio ou uma supressão dos nossos impulsos”. Donde se conclui que a escola não deve ter a função de entretenimento, pois isto os jovens têm em excesso no seu cotidiano. Os pais de Fábio acreditavam que a escola deveria estar em consonância com o mundo do trabalho, porém é esse corte - a lógica do trabalho escolar - que prepara o sujeito para a vida profissional, além da escrita, da leitura, 
da possibilidade de argumentação verbal e escrita, que advêm do trabalho sobre a cultura escolar. Era justamente isso que Fábio se recusava a fazer e tinha dos pais uma atitude complacente.

Para a mentalidade de certos pais de classe média, tudo o que foge do seu domínio é visto como perigoso, pois aí não se pode arbitrar. Quando têm de procurar profissionais da área “psi”, são regidos pela cordialidade, na acepção de Sérgio Buarque de Holanda (2006), e, na lógica afetiva da cordialidade e do favor, o profissional, que é pago, não deveria se contrapor à família.

Na verdade, o profissional pode representar um terceiro, aquele que não se submete aos desejos dos pais e que procura fazer valer a lei impessoal. Mas ele pode também encontrar obstáculos em relação à sua intervenção, pois, além da resistência dos pais de que fala a psicanálise, há, também, a desconfiança em relação àquele que está fora do mundo familiar.

Essa questão remete a uma pergunta formulada por ocasião da apresentação dos estudos de casos - aqueles atendimentos foram bem-sucedidos ou não? O fato de eles terem sido suspensos antes de seu término já é um indício de fracasso, no entanto uma reflexão mais apurada pode revelar outros aspectos.

No caso de Fábio, o primeiro objetivo foi favorecer a entrada na lógica do trabalho escolar; em termos psicanalíticos, de levá-lo à renúncia pulsional e inseri-lo no mundo da cultura. O segundo objetivo foi possibilitar o movimento de acomodação ao objeto de conhecimento, de adaptar-se à sua estrutura, inibindo seu desejo de transformação cega e impulsiva do objeto de conhecimento. Creio que, em algum grau, esses objetivos foram alcançados. O jovem também enriqueceu-se com a troca com os objetos culturais, ampliou seu repertório e saiu de uma tendência a criar projetos marcados pela onipotência. Havia ainda muitas outras metas a serem alcançadas, no entanto elas eram secundárias, diante da situação em que o adolescente se encontrava.

O tratamento, ainda que relativamente curto, consistiu num espaço em que Fábio pôde estabelecer uma relação com um adulto mediada por um terceiro - a cultura. O jovem teve a oportunidade de entrar em contato com outro modelo identificatório e minha preocupação foi sempre remetê-lo à cultura: exposições, livros, sites, a própria experiência escolar, etc. Por fim, apesar de ele se ocupar de atividades criativas, tínhamos um “contrato de trabalho”, e sempre cobrei dele esforço e perseverança. Em suma, eu era uma representante do mundo dos 
adultos que mostrava que valia a pena fazer o esforço da travessia da adolescência em direção ao mundo adulto.

No caso de Otto, o tratamento também tinha o objetivo de levá-lo à lógica do trabalho escolar. No entanto, o adolescente já havia se "convertido" ao mundo da cultura, por sua própria história. Se isso já representava uma parte do caminho andado, o objetivo era favorecer a transformação desse saber - que ele representasse um valor de uso, e não só um valor de troca; possibilitar que o saber o ajudasse a estabelecer a intersignificação, como diz Charlot, pois o uso que ele fazia do conhecimento parecia ser ou da exibição, ou da competição. O atendimento no caso de Otto foi mais centrado no sintoma, na acepção de Paín, do que no caso de Fábio.

Otto conseguiu submeter-se à lógica do trabalho escolar, passou a estudar com os amigos, a solicitar ajuda quando necessário. Começou a valorizar os professores, reconhecendo o adulto como alguém que tem um saber a mais, e passou até mesmo a gostar de algumas disciplinas. Passou a ter interesse pelos desafios intelectuais, fez da aprendizagem formal um "desafio olímpico”. Sua fala, ao final do atendimento, de que havia se lembrado na escola de coisas que havíamos discutido, de estratégias cognitivas que havíamos desenvolvido, me levam a acreditar que ele também se beneficiou do trabalho.

Por fim, no caso de Otto, ele acabou reconhecendo que necessitava de uma ajuda psicoperapêutica — e este também é um dos objetivos do atendimento psicopedagógico, quando isso se faz necessário. Fábio não reconheceu abertamente tal necessidade, no entanto não se opôs a submeter-se ao psicodiagnóstico.

Ao avaliar esses casos, é inevitável a constatação de algumas limitações. Primeiramente, minhas limitações profissionais, no sentido de não conseguir mobilizar suficientemente os pais para que colocassem em questão sua omissão do exercício da função parental, da afirmação da diferença geracional e da tomada de consciência da complementaridade deles próprios no sintoma do filho. Esses pais não conseguiram refletir e processar os dados discutidos em nossas entrevistas; mantinham-se inalterados em suas posturas.

Em segundo lugar, limitações do atendimento psicopedagógico. O objetivo da psicopedagogia é voltado para a aprendizagem, no entanto havia outros elementos que clamavam por um cuidado. Se os jovens se beneficiaram minimamente desse trabalho, a 
demanda por uma psicoterapia foi ficando progressivamente mais clara. No caso de Fábio, urgente.

Depois de entrar em contato com o referencial de Jeammet e Corcos, (2005), fica evidente a necessidade de, nesses casos, propor a terapia bi-focal. No entanto, seria necessário fazer uma adaptação a esse modelo, no sentido de indicar um trabalho terapêutico aos pais, principalmente em relação aos pais de Fábio, que necessitavam de uma orientação mais enfática, que não parece corresponder à minha alçada.

Por fim, vale assinalar a limitação dos pais. É evidente que esses pais não foram continentes para as oscilações dos filhos em sua conquista de autonomia. Esses jovens estavam apresentando aquilo que Jeammet e Corcos chamam de recusa escolar, pois se encontravam, naquele momento crítico, de passagem de um mundo mais protegido, para um mundo que demandava mais autonomia. Isso é evidente no caso de Otto, que, além de enfrentar o desafio de estar iniciando um novo ciclo escolar, saiu do abrigo da avó para morar numa cidade grande, em que tinha como adulto responsável aquele que havia se omitido em relação ao exercício da função paterna.

Analisando a fundo a problemática desses jovens, foi possível verificar que a recusa escolar estava relacionada a determinações transgeracionais, mais especificamente, desejos reprimidos desses pais. Nos dois casos, havia a recusa da realidade relacionada ao fim da juventude desses pais. Isso nos remete ao que Jeammet comenta sobre o filho ser prisioneiro dos conflitos dos pais: ${ }^{139}$

[...] o adolescente é parasitado por dificuldades que não são suas, mas que seus pais fazem suas. Ele não consegue mais desembaraçar aquilo que, em seus problemas, provém dele ou de seus pais. Sem saber, ele se torna de alguma forma cativo de forças que o alienam ao passado, a rancores, a vinganças ou necessidades de reparação, e que poderão influir sobre seu próprio futuro. (2007, p. 82)

O jovem que apresenta a conduta de recusa escolar está atuando, realizando o desejo reprimido dos pais. A recusa escolar está, nesses casos, associada a esse emaranhamento de gerações, à pseudomutualidade, enfim, à dependência familiar. São adultos e adolescentes presos a determinações inconscientes, em que se torna difícil atribuir o quinhão de cada uma nessa problemática.

\footnotetext{
139 Jeammet se refere a conflitos conjugais dos pais, mas acreditamos que a idéia pode ser aplicada ao caso ao que me refiro - a complementaridade dos pais no sintoma do filho.
} 
A recusa escolar, como sintoma, pode ser considerada um alerta de que algo não vai bem na travessia do adolescente rumo ao mundo adulto. Há um conflito entre a necessidade de conquistar a autonomia e a tendência a manter os vínculos de dependência. Nesse caso, o ambiente está sendo complementar ao problema e até mesmo o seu causador.

Até aqui, enfocamos o jovem que é levado a atuar o desejo reprimido dos pais, mais especificamente, a manifestar a conduta de passividade-ativa, por meio da recusa escolar, nas palavras de Jeammet e Corcos (2005). Nesse sentido, a recusa de Fábio a jogar o jogo escolar encobre a recusa à institucionalização dos pais. A recusa de Otto a entrar na lógica do trabalho escolar encobre a recusa do pai a assumir a responsabilidade pelo filho.

No entanto, é possível deslocar o foco para a atuação dos pais. Falo desses pais que, apesar da postura aparentemente moderna, por vezes se deixam tomar por atitudes profundamente autoritárias, típicas da elite brasileira, que se arroga o direito de impor sua vontade. A modernidade reativa, por vezes, cobra o seu preço; corresponde ao retorno do arcaico recalcado.

Exemplo disso foi a atitude intempestiva do pai de Fábio de tirar o filho da escola. Ou do pai de Otto de ficar profundamente irritado com o filho, quando este fumou maconha na varanda perto dos vizinhos. Vale assinalar que foi ele que permitiu ao rapaz de 16 anos, recém-chegado do Nordeste, morar sozinho, sendo que ele também não fez nenhuma interdição severa em relação ao uso da maconha.

Nesse sentido, esses jovens parecem estar duplamente cativos: presos aos seus impulsos, que não foram refreados pelos adultos, e presos aos desejos autoritários de juventude de seus pais.

A recusa escolar, nesses casos, expressa uma dupla denúncia: aos pais, que se negam a marcar a diferença geracional, e à sociedade, que encobre em suas camadas invisíveis suas raízes coloniais e escravocratas. 


\section{Bibliografia}

ABERASTURY, A.; KNOBEL, M. Adolescência normal. 4. ed. Porto Alegre: Artes Médicas, 1985. 92 p.

ADORNO, T. W. De la relación entre Sociologia Y Psicologia. In: Actualidad de la Filosofia. Barcelona: Paidós/I.C.E.-U.A.B., 1991. 204 p.

AMARAL, M. Apresentação do livro. In: JEAMMET, P.; CORCOS, M. Novas problemáticas da adolescência: Evolução e manejo da dependência. São Paulo: Casa do Psicólogo, 2005. 142 p.

AMARAL, M. Culturas juvenis X cultura escolar: repensando as noções de (in)disciplina e autoridade no âmbito da educação. In: Psicanálise, Educação e Transmissão, 6. São Paulo, 2006a. Anais eletrônicos disponíveis em: $<$ http://www.proceedings.scielo.br/scielo.php?script=sci_arttext\&pid=MSC00000000320070 00100011\&lng=pt\&nrm=abn>. Acesso em: 02 dez. 2007.

AMARAL, M. O limite da fronteira freudiana. In: Revista Educação. Edição 112, São Paulo: Segmento, agosto 2006b. p. 26-35.

AMORIM, M. A escola e o terceiro excluído. Revista de Psicologia e Psicanálise. n. 1, Rio de Janeiro: Primavera, 1989. p. 81-95.

ANDERSON, P. As Origens da Pós-Modernidade. Rio de Janeiro: Zahar, 1999. 165 p.

ARENDT, H. Entre o passado e o futuro. 4. ed. São Paulo: Perspectiva, 1997. 348 p.

ARIÈS, P. História Social da Criança e da Família. Rio de Janeiro: Guanabara, 1973. p. 279.

AULAGNIER, P. Um intérprete em busca de um sentido. Vol. 2. São Paulo: Escuta, 1990. $194 \mathrm{p}$.

BAUDRILLARD, J. A sociedade de consumo. Rio de Janeiro: Elfos, 1995. 213 p.

BAUTHIER, E.; ROCHEX, J. Y. Relação com os Saberes e Trabalho de Escrita em Filosofia e Ciências Econômicas e Sociais. In: CHARLOT, B. (org.) Os jovens e o saber. Perspectivas mundiais. Porto Alegre: Artes Médicas, 2001. 152 p.

BERLINCK, M. T. Prefácio. Psicanálise da clínica cotidiana. São Paulo: Escuta, 1988. 218 p. 
BERMAN, M. Tudo que é sólido desmancha no ar. 17. ed. A aventura da modernidade. São Paulo: Cia. das Letras, 2000. 360 p.

BEAUCHESNE, H.; GIBELLO, B. Traité de psycopathologie infantile. Paris: PUF, 1991. $290 \mathrm{p}$.

BIN, K. Fenomenologia da depressão estado-limite.

http://www.fundamentapsychopathology.org/art/set8/1.pdf. Acesso em 20/01/2008

BIRMAN, J. Psicanálise, ciência e cultura. Rio de Janeiro: Jorge Zahar, 1994. 204 p.

BIRMAN, J. Insuficientes, um esforço a mais para sermos irmãos! In: KEHL, M. R. Função fraterna. Rio de Janeiro: Relume Dumará, 2000. 244 p.

BIRMAN, J. Arquivos do mal-estar e da resistência. Rio de Janeiro: Civilização Brasileira, 2006. 418 p.

BLEICHMAR, H. Introdução ao estudo das perversões. Tradução de Emília de Oliveira Diehl. Porto Alegre: Artes Médicas, 1991. 84 p.

BOSSA, N. A. A Psicopedagogia no Brasil: contribuições a partir da prática. Dissertação de mestrado. 155 f. Faculdade de Educação da Pontifícia Universidade Católica de São Paulo, São Paulo, 1993.

BOWLBY, J. Formação e Rompimento dos Laços Afetivos. 3. ed. São Paulo: Martins Fontes, 2001. 228 p.

BUCCI, E.; KEHL, M. Videologias. São Paulo: Boitempo, 2004. 252 p.

BORUCHOVITCH, E. Estratégias de Aprendizagem e desempenho escolar: considerações sobre a prática educacional. In: Rev. Psicologia: Reflexão e Crítica. Vol. $12 \mathrm{n}^{\circ}$ 2. Porto Alegre, 1999. http://www.scielo.br/scielo.php?pid=S010279721999000200008\&script=sci_arttext\&tlng=pt. Acesso em 19/02/08

CALLIGARIS, C. A Adolescência. São Paulo: Publifolha, 2000. 81 p.

CANDIDO, A. A dialética da malandragem. In: ALMEIDA, M.A. Memórias de um sargento de milícias. Edição crítica de Cecília Lara. Rio de Janeiro: Livros Técnicos e Científicos Ed., 1978, p. 317-342.

CASTORIADIS, C. Psicoanálisis y Política. Diarios clínicos. Revista de psicoanálisis con niños y adolescentes, n. 4, p. 19-31, 1992. 
CATIPOVIC, M.P.; LADAME, F. (org.) Adolescence et Pscichanalyse: une histoire. Paris: Delachaux et Niestlé, 1997. 245 p.

CHARLOT, B. Da relação com o saber. Elementos para uma teoria. Porto Alegre: Artes Médicas, 2000. 93 p.

CHARLOT, B. (org.) Os jovens e o saber. Perspectivas mundiais. Porto Alegre: Artes Médicas, 2001. 152 p.

CHARTIER, A. M. Leitura escolar. Entre pedagogia e sociologia. Revista Brasileira de Educação. n. 0, São Paulo: ANPEC, p. 17-52, 1995.

CHARTIER, A. M. Métodos de leitura e fracasso escolar. Texto relativo à palestra ministrada pela autora em 12/12/2000 e divulgado pelo Centro de Memória da Faculdade de Educação da Universidade de São Paulo, 2000.

COSTA, J. F. Narcisismo em Tempos Sombrios. In: RODRIGUES-FERNANDES, H. (org.). Tempo de Desejo. São Paulo: Brasiliense, 1991.136 p.

COSTA, J. F. O vestígio e a aura. Corpo e consumismo na moral do espetáculo. Rio de Janeiro: Garamond, 2004. 242 p.

CRUZ, J. G. Os testes e a clínica. In: FERNÁNDEZ, A. A inteligência aprisionada. Abordagem psicopedagógica clínica da criança e sua família. Porto Alegre: Artes Médicas, 1990. $261 \mathrm{p}$.

CYPEL, S. O papel das funções executivas na aprendizagem. (s/d) In: http:// www.neurodesenvolvimento.com.br/ artigos/artigo_opapeldasfuncoes.pdf. Acesso em 20/07/2007.

DAVIS, M.; WALLBRIDGE, D. Limite e espaço. Uma Introdução à Obra de D. W. Winnicott. Rio de Janeiro: Imago, 1982. 205 p.

DEBERT, G. G. A reinvenção da velhice. cap. 1. As classificações etárias e a juventude como estilo de vida. São Paulo: EDUSP/FAPESP, 1999. 266 p.

DEBORD, G. A sociedade do espetáculo. $2^{\mathrm{a}}$ reimpressão. Rio de Janeiro: Contraponto, 2000. $237 \mathrm{p}$.

DELVAL, J. Introdução à prática do método clínico: descobrindo o pensamento das crianças. Porto Alegre: Artes Médicas, 2002. 267 p.

DOLTO, F. Psicanálise e Pediatria. Rio de Janeiro: Zahar, 1984. 259 p. 
DOLTO, F. Prefácio. In: MANONNI, M. A Primeira Entrevista em Psicanálise. Rio de Janeiro: Campus, 1985. 107 p.

DORIN, E. Dicionário de Psicologia. São Paulo: Melhoramentos, 1978

DUBET, F. Des jeunesses et des sociologies. Les cas français. Sociologie et societés. vol. XXVIII, n. 1, 1996a.

DUBET, F. Sociologia da Experiência. Lisboa: Instituto Piaget, 1996b. 282 p.

DUBET, F. A formação dos indivíduos: a desinstitucionalização. Revista Contemporaneidade e Educação. Ano 3, Vol. 3, Rio de Janeiro: IEC, 1998. p. 27-33.

DUBET, F.; MARTUCELLI, D. À l‘École: Sociologie de l'expérience scolaire. Paris: Seuil, 1996.

DUFOUR, D.-R. A arte de reduzir as cabeças. Sobre a nova servidão na sociedade ultraliberal. Rio de Janeiro: Cia. de Freud, 2005.

ELKIND, D. Crianças e adolescentes. 2. ed. Ensaios interpretativos sobre Jean Piaget. Rio de Janeiro: Zahar, 1975. 187 p.

FAVARETTO, C. F. Moderno, pós-moderno, contemporâneo na educação e na arte. Tese de Livre-docência apresentada na Faculdade de Educação da Universidade de São Paulo, São Paulo, 2004.

FERNÁNDEZ, A. A inteligência aprisionada. Abordagem psicopedagógica clínica da criança e sua família. Porto Alegre: Artes Médicas, 1990. 261 p.

FIGUEIRA, S. A. O “moderno” e o “arcaico" na nova família brasileira: notas sobre a dimensão invisível da mudança social. In: FIGUEIRA, S. A. Uma nova família? O moderno e o arcaico na nova família de classe média brasileira. Rio de Janeiro: Jorge Zahar, 1987. 111 p.

FIGUEIRA, S. A. A família de classe média atual no Rio de Janeiro: algumas considerações. Psicologia USP. São Paulo: Universidade de São Paulo, 3(1/2), 1992. p. 83-92.

FOUCAULT, M. Vigiar e Punir: histórias da violência nas prisões. 7. ed. Petrópolis: Vozes, 1977. 277 p.

FREUD, A. L’Ádolescence. In: CATIPOVIC, M.P.; LADAME, F. (org.) Adolescence et Pscichanalyse: une histoire. Paris: Delachaux et Niestlé, 1997. 245 p.

FREUD, S. Três ensaios sobre a sexualidade (1905). Edição Standard Brasileira das Obras Completas. Vol. VII. Rio de Janeiro: Imago, 1974. 
FREUD, S. Análise de um caso de fobia em um menino de cinco anos, 1909, E.S.B. Vol. X. Rio de Janeiro: Imago, 1974.

FREUD, S. Notas psicanalíticas sobre um relato autobiográfico de um caso de paranóia (dementia paranoides), 1911. E.S.B. Vol. XII. Rio de Janeiro: Imago, 1974.

FREUD, S. Totem e Tabu, 1913. E.S.B. Vol. XIII. Rio de Janeiro: Imago, 1974.

FREUD, S. Sobre o narcisismo: uma introdução, 1914. E.S.B. Vol. XIV. Rio de Janeiro: Imago, 1974.

FREUD, S. Artigos sobre metapsicologia. O inconsciente, 1915. E.S.B. Vol. XIV. Rio de Janeiro: Imago, 1974.

FREUD, S. Além do princípio do prazer, 1920. E.S.B. Vol. XVIII. Rio de Janeiro: Imago, 1974.

FREUD, S. Psicologia de grupo e a análise do ego, 1921. Rio de Janeiro: Imago, 1974.

FREUD, S. O Ego e o Id, 1923. E.S.B. Vol. XIX. Rio de Janeiro: Imago, 1974.

FREUD, S. O Fetichismo, 1927. E.S.B. Vol. XXI. Rio de Janeiro: Imago, 1974.

FREUD, S. Novas conferências introdutórias sobre psicanálise, 1932. E.S.B. Vol. XXII. Rio de Janeiro: Imago, 1974.

FREUD, S. Esboço da Psicanálise, 1938a. E.S.B. Vol. XXIII. Rio de Janeiro: Imago, 1974.

FREUD, S. A divisão do ego no processo de defesa, 1938b. E.S.B. Vol. XXIII. Rio de Janeiro: Imago, 1974.

GALVÃO, I.; LEITE, L. B. Uma introdução à história de Victor de Aveyron e suas repercussões. In: GALVÃO, I.; LEITE, L. B. (org.). A educação de um selvagem. As experiências pedagógicas de Jean Itard. São Paulo: Cortez, 2000.

GAGNEBIN, J. M. Sete aulas sobre linguagem, memória e história. Rio de Janeiro: Imago, 1997. $186 \mathrm{p}$.

GOLA, M. F. M. Instrumentos psicopedagógicos para o conhecimento do sujeito que não aprende. Revista de Psicopedagogia. 18(49), 1999.

GREEN, A. B. Alter - Jornal de Estudos Psicodinâmicos, Brasília, D.F., Vol. VII, n. 1, p. 916, jan./abril 1977. 
GREEN, A. B. O intrapsíquico e o intersubjetivo: pulsões e/ou relações de objeto. Revista de Psicanálise da Sociedade Psicanalítica de Porto Alegre. Porto Alegre. Vol. XII, n. 1, p. 5183, abril 2005.

HABERMAS, J. Modernidade, um projeto inacabado. In: ARANTES, O. B \& P. E. Um ponto cego no projeto moderno de Jürgen Habermas. São Paulo: Brasiliense, 1992. 149 p.

HALL, S. A identidade cultural na pós-modernidade. Rio de Janeiro: DP\&A Editora, 2005.

HEBRARD, J. Instruction ou éducation. In: Ornicar - Bulletin Periodique du Champ Freudien. n. 26-27, p. 122-123. Paris: Seuil, s/d

HERRMANN, F. Clínica extensa. In: BARONE, L. C. et al. A Psicanálise e a clínica extensa: III Encontro Psicanalítico da Teoria dos Campos por Escrito. São Paulo: Casa do Psicólogo, 2005. 460 p.

HOBSBAWN, E. Era dos extremos. O breve século XX. 1914-1991. São Paulo: Cia. das Letras, 1995. 598 p.

HOLANDA, S. B. Raízes do Brasil. Edição comemorativa 70 anos. São Paulo: Cia. das Letras, 2006. 447 p.

HOUAISS, A. Dicionário Houaiss da língua portuguesa. Rio de Janeiro: Objetiva, 2001.

JAMESON, F. Pós-modernismo: a lógica cultural do capitalismo tardio. São Paulo: Ática, 1996. $431 \mathrm{p}$.

JEAMMET, P. Reflexões psicopatológicas sobre os comportamentos de fracasso no adolescente e no jovem adulto. Tradução de Mônica do Amaral e Vânia Ghirello Garcia do artigo Reflexions Psychopathologiques sur les conduites d'échec chez l'adolescent et le jeune adulte (p. 9-25), 2002. mimeo

JEAMMET, P. As patologias do agir na adolescência. Tradução de Lucas Pierini e Mônica do Amaral, do artigo "Les pathologies de l'agir à l'adolescence”. Bulletin de L'ACIRP, Adolescence et psychanalyse, Journée des CMPP. Besançon, 09/04/1994, n. 2, p. 75-92, 1994.

JEAMMET, P. Troubles du comportement, violence et fonction du symptome a l'adolescence. In: Simpósio Internacional do Adolescente, 1, 2005, São Paulo. Proceedings online Available from:

<http://www.proceedings.scielo.br/scielo.php?script=sci_arttext\&pid=MSC00000000820050 00100014\&lng=en\&nrm=abn>. Acess on: 02 Dec. 2007. 
JEAMMET, P. 100 Respostas a 100 questões sobre a adolescência. Petrópolis: Vozes, 2007, 261 p.

JEAMMET, P.; CORCOS, M. Novas problemáticas da adolescência: evolução e manejo da dependência. São Paulo: Casa do Psicólogo, 2005. 142 p.

JATOBÁ, C. M. R. Às sombras das escalas: um estudo sobre a concepção de anormalidade em Alfred Binet. Tese de doutoramento. 157 f. Faculdade de Educação da Universidade de São Paulo, São Paulo, 2002.

KAUFMANN, P. (ed.) Dicionário enciclopédico de psicanálise. O legado de Freud e Lacan. Rio de Janeiro: Zahar, 1996. 789 p.

KATO, M. O aprendizado da leitura. São Paulo: Martins Fontes, 1985. 121 p.

KEHL, M. R. Existe uma função fraterna? In: KEHL, M. R. (org.) Função fraterna. Rio de Janeiro: Relume Dumará, 2000. 244 p.

KEHL, M. R. Em defesa da família tentacular, 2003. Disponível em: http://www.mariaritakehl.psc.br. Acesso em 20/02/08.

KEHL, M. R. A juventude como sintoma da cultura. In: NOVAES, R.; VANNUCHI, P. Juventude e Sociedade. Trabalho, Educação, Cultura e Participação. São Paulo: Instituto de Cidadania e Fundação Perseu Abramo, 2004. 303 p.

KEHL, M. R. Quem tem moral com os adolescentes? (Duas hipóteses sobre a crise na educação no século XXI). In: KUPFER, M.C.; LAJONQUIÉRE, L.; VOLTINI, R. (org.) Anais do IV Colóquio do LEPSI. São Paulo: Universidade de São Paulo: 2004b.

KEHL, M. R. Problemas da juventude atual. In: http://www.mariaritakehl.psc.br/agenda.php. Acesso em 17/02/07.

KERNBERG, O. et alii Psicoterapia dinâmica de pacientes borderlines.Porto Alegre: Artes Médicas, 1991. 212 p.

LAHIRE, B. Sucesso escolar nos meios populares. As razões do improvável. São Paulo: Ática, 1997.367 p.

LASCH, C. O mínimo eu. Sobrevivência psíquica em tempos difíceis. 5. ed. São Paulo: Brasiliense, 1984. 286 p. 
LAJONQUIÈRE, L. Conversando com Sara Paín. Estilos da Clínica: Revista sobre a infância com problemas. Ano 1, Vol. 1. São Paulo: Instituto de Psicologia da Universidade de São Paulo, 1996. p. 94-105.

LAJONQUIÈRE, L. As formas da ilusão. Infância e ilusão (psico)pedagógica. Petrópolis: Vozes, 1999. 204 p.

LAPLANCHE, J. Novos Fundamentos para a Psicanálise. São Paulo: Martins Fontes, 1992, $174 \mathrm{p}$.

LAPLANCHE, J.; PONTALIS, J.-B. Vocabulário da Psicanálise. 9. ed. São Paulo: Livraria Martins Fontes Editora Ltda., 1986.

LE BRETON, D. Juventude Transviada. Folha de São Paulo. Suplemento Mais! 23 jul. 2006.

LESOURD, S. A construção social do adolescente no laço social. Petrópolis: Vozes, 2004.

LIPOVETSKY, G. A Era do Vazio. São Paulo: Manole, 2006.

LYOTARD, J.F. A Condição Pós-Moderna. 6. ed. Rio de Janeiro: José Olímpio, 1998. 131 p.

MAC DONELL, J.J.C. Manual - Provas do diagnóstico operatório. Buenos Aires: CEM Centro de Material Educativo, 2004. 50 p.

MACEDO, L. Nível operatório de escolares (11 a 15 anos) conforme a EDPL: estudo intercultural, transversal e longitudinal. 238 f. Tese de Livre-docência. São Paulo: Instituto de Psicologia da USP, 1983.

MACHADO, R. Ciência e saber. A trajetória da arqueologia de Foucault. Rio de Janeiro: Graal, 1988.

MALCHER-LOPES, R.; RIBEIRO, S. Efeitos mentais da maconha In: Revista Mente e Cérebro. Ano XV, nº 180. São Paulo: Ediouro. p. 40-47.

MANONNI, M. A criança, sua "doença” e os outros: O sintoma e a palavra. Rio de Janeiro: Zahar, 1971. 251 p.

MANONNI, M. A Primeira Entrevista em Psicanálise. Rio de Janeiro: Campus, 1985. 107 p. MANONNI, M. Educação Impossível. Rio de Janeiro: Francisco Alves, 1977. 317 p.

MARCELli, D.; BRACONNIER, A. Adolescência e Psicopatologia. 6. ed. Porto Alegre: Artmed, 2007, 439 p. 
MARGULIS, M.; URRESTI, M. La juventud es más que una palabra: ensayos sobre cultura y juventud. Buenos Aires: Editorial Biblos, 1998. 242 p.

MAZZOTTI, A. J. A. Usos e abusos dos estudos de caso. Cadernos de Pesquisa, V. 36, $\mathrm{n}^{\circ} 129$, p. 637-651, set./dez.2006.

MELUCCI, A. O jogo do eu. A mudança de si em uma sociedade global. São Leopoldo: Unisinos, 2004. 184 p.

MEZAN, R. Tempo de Muda: ensaios de psicanálise. São Paulo: Cia das Letras, 1998. 367 p. MEZAN, R. Interfaces da psicanálise. São Paulo: Cia. das Letras, 2002. 585 p.

MOKREJS, E. Durval Marcondes - o primeiro capítulo da Psicanálise e da Psicopedagogia em São Paulo. Revista da Faculdade de Educação. Ano 14, Vol. 2, São Paulo: Faculdade de Educação da Universidade de São Paulo, 1988. p. 193-209.

NICOLACI-da-COSTA, A.M. Mal-estar na família: descontinuidade e conflito entre sistemas simbólicos. In: FIGUEIRA, S.A. (org.) Cultura da psicanálise. São Paulo: Brasiliense, 1985. 201 p.

OLIVEIRA, M. K. Letramento, cultura e modalidades de pensamento. In: KLEIMAN, A B. (org.) Os significados do letramento. Uma nova perspectiva sobre a prática social da escrita. Campinas: Mercado de Letras, 2004. 294 p.

OUTEIRAL, J. Adolescer: estudos revisados sobre a adolescência. 2. ed. Porto Alegre: Revinter, 2003. 146 p.

PAÍN, S. Diagnóstico e tratamento dos problemas de aprendizagem. Porto Alegre: Artes Médicas, 1985.

PAÍN, S. Psicometria genética. São Paulo: Casa do Psicólogo, 1992. 235 p.

PAÍN, S. Subjetividade e Objetividade: Relações entre desejo e conhecimento. São Paulo: CEVEC - Centro de Estudos Educacionais Vera Cruz, 1996. 125 p.

PAÍN, S. In: Parente, S.M.B.A. (org) Encontros com Sara Paín. São Paulo: Casa do Psicólogo, 2000, 135 p.

PARENTE, S. M. B. A. Pelos caminhos da ignorância. São Paulo: Casa do Psicólogo, 2000.

PARENTE, S. M. B. A. Em busca da comunicação significativa: Transformações no olhar de uma analista na clínica da inibição intelectual. Tese de doutorado, Faculdade de Psicologia da Pontifícia Universidade Católica de São Paulo, São Paulo, 2005. 
PATTO, M. H. S. A produção do fracasso escolar. Histórias de submissão e rebeldia. $4^{\mathrm{a}}$ reimpressão. São Paulo: T. A. Queirós, 1996. 385 p.

PENOT, B. Figuras da recusa. Aquém do negativo. Porto Alegre: Artes Médicas, 1992a. 209 p.

PENOT, B. A recusa da realidade na teoria psicanalítica. Revista Percurso. Instituto Sedes Sapentiae. Número 9, 1992 b.

PERALVA, A. O jovem como modelo cultural. Revista Brasileira de Educação, n. 5/6, 1997. PERRENOUD, P. Ofício de aluno e sentido do trabalho escolar. Porto: Porto Editora, 1995. PIAGET, J.; INHLEDER, B. A psicologia da criança. 9. ed. São Paulo: Difel, 1986. 135 p. RAMOS, C. Elementos para uma Psicologia do sujeito Cativo. Revista de Psicologia da USP. V. 10 n. 2, São Paulo, 1999.

RELVAS, A. P. Adolescente(s), família (s) e escola(s). In: MEDEIROS, M. T.; SERPA, A. Adolescência: Abordagens, investigações e contextos de desenvolvimento. Documento elaborado pela Direção Regional de Educação de Portugal, 2000.

RIBEIRO, R. J. A sociedade contra o social. O alto custo da vida pública no Brasil. São Paulo: Cia. das Letras, 2000. 232 p.

ROSA, M. D. A pesquisa psicanalítica dos fenômenos sociais e políticos: metodologia e fundamentação teórica. Revista Mal-Estar e Subjetividade, Fortaleza, v. IV, n. 2, p. 329-348, 2004.

ROUANET, S. P. As razões do iluminismo. $7^{\mathrm{a}}$ reimpressão. São Paulo: Cia. das Letras, 2000. 349 p.

ROUDINESCO, E. A Família em Desordem. Rio de Janeiro: Jorge Zahar, 2003.

SARLO, B. Cenas da vida pós-moderna. Rio de Janeiro: UFRJ, 1997.

SARLO, B. Tempo presente. Notas sobre a mudança de uma cultura. Rio de Janeiro: José Olímpio, 2004. 238 p.

SARTI, C. A. O jovem na família: o outro necessário. In: NOVAES, R.; VANNUCHI, P. (org.) Juventude e Sociedade.Trabalho, Educação, Cultura e Participação. São Paulo: Inst. Cidadania Perseu Abramo, 2004. 
SCHWARZ, R. Um mestre na periferia do capitalismo: Machado de Assis. São Paulo: Duas Cidades, 1990. 227 p.

SENNETT, R. O declínio do homem público: as tiranias da intimidade. São Paulo: Cia. das Letras, 1988. 447 p.

SINGLY, F. Prefácio. In: PEIXOTO, C.; SINGLY, F. CICCHELLI, V. (org.) Família e Individualização. Rio de Janeiro: FGV, 2000. 196 p.

SOUZA, M. C. C. C. Joaquim Nabuco: uma trajetória de leitor. Extraído de BLAJ, I.; MONTEIRO, J. M. História \& Utopias. São Paulo: ANPUH/CNPQ, 1996. p. 355-364.

SOUZA, M. C. C. C. À sombra do fracasso escolar: a psicologia e as práticas pedagógicas. Estilos da Clínica: Revista sobre a infância com problemas. Ano 3, Vol. 5, São Paulo: Instituto de Psicologia da Universidade de São Paulo, 1998.

SOUZA, M. C. C. C. A psicologia e a experiência pedagógica. In: SOUZA, M. C. C. C., A memória e a sombra - A escola brasileira entre o Império e a República. Belo Horizonte: Autêntica, 1999.

SOUZA, M. C. C. C. Escola e Memória. Bragança Paulista: EDUSF, 2000.

SOUZA, M. C. C. C. Os estudos sobre aspectos psicossociais de adolescentes. In: SPÓSITO, M. (coord.) Juventude brasileira e escolarização (1980-1998). Brasília: MEC/Inep/Comped, 2002.

SOUZA, M. C. C. C. A insustentável leveza de estar em família: alguns apontamentos históricos, sociológicos e psicanalíticos. In: CASTELO BRANCO, L. (org.) Contemporaneidade: alguns desafios. São Paulo: Pulsional, 2004.

SOUZA, O. Reflexão sobre a extensão dos conceitos e da prática psicanalítica. In: ARAGÃO, L. T.; CALligARIS, C.; COSTA, J. F.; SOUZA, O. Clínica do social. São Paulo: Escuta, 1991. $118 \mathrm{p}$.

SZTERLING, S. Diálogo entre a Psicanálise e a Psicopedagogia: sobre a (im)possibilidade de aprender. 93 p. Dissertação de Mestrado. Faculdade de Educação da Universidade de São Paulo, São Paulo, 2000.

SPOSITO, M. P. Algumas hipóteses sobre as relações entre movimentos sociais, juventude e educação. Revista Brasileira de Educação. ANPED, n. 13, 2000. 
TANIS, B. A família atual, a constituição subjetiva da criança e a psicanálise. In: COMPARATO, M. C. M; MONTEIRO, D. S. F. A criança na contemporaneidade e a Psicanálise. Diálogos interdisciplinares: família e sociedade. São Paulo: Casa do Psicólogo, 2001. 181 p.

WARDE, M. J. Para uma história disciplinar: psicologia, criança e pedagogia. In: FREITAS, M. C. (org.). História Social da Infância no Brasil. São Paulo: Cortez, 1997. 312 p.

WINNICOTT, D. W. O ambiente e os processos de maturação. 3. ed. Porto Alegre: Artes Médicas, 1990. 268 p.

YAMAMOTO, O. H. A educação brasileira e a tradição marxista (1970-1990). Natal: EDUFRN/São Paulo: Moraes, 1996. 106 p.

YIN, R. Estudo de caso: planejamento e métodos. Porto Alegre: Bookman, 2001. 212 p.

ZIMMERMANN, V. B. O adolescente e a recusa do não saber. Pulsional Revista de Psicanálise. São Paulo: Editora Escuta. 14 (144): 14-21, abril 2001.

ZIMMERMANN, V. B. Adolescentes estados-limite. A instituição como aprendiz de historiador. São Paulo: Escuta, 2007. 141 p. 